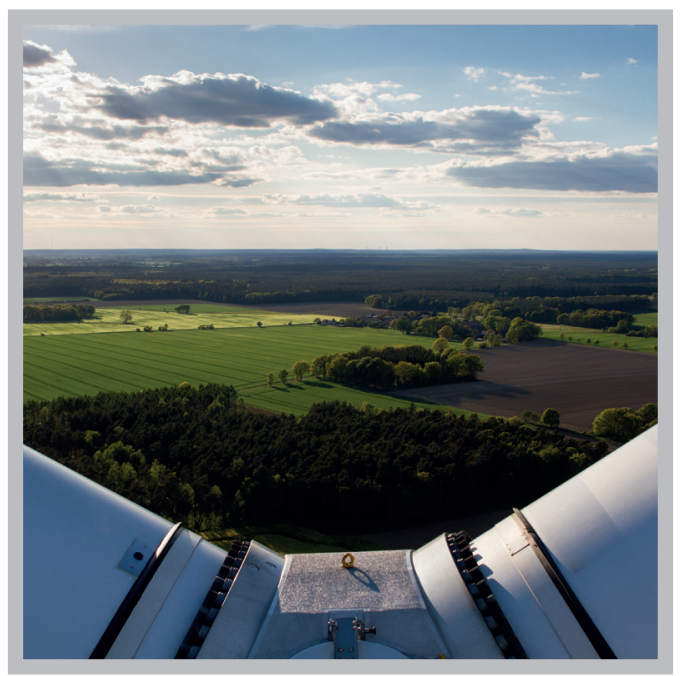

\title{
Cleantech as a key enabler of sustainable development:
}

Regional economic and environmental effects of energy transitions

Simon Jenniches 
Cleantech as a key enabler of sustainable development Simon Jenniches

Copernicus Institute of Sustainable Development, Utrecht University ISBN: 978-94-6416-193-9

Copyright: $\odot 2020$ by Simon Jenniches

All rights reserved. No part of this thesis may be reproduced, stored or transmitted in any way or by any means without the prior permission of the author, or when applicable, of the publishers of the scientific papers.

Funding has been received from the render (Regional Dialogue Energy Transition) project (No. 687809), which is part of the FONA (Research for Sustainable Development) programme funded by the German Federal Ministry of Education and Research (BMBF) (FKZ 033L116G).

Layout and design: Rowen Aker, persoonlijkproefschrift.nl

Printing: Ridderprint | www.ridderprint.nl 


\section{Cleantech as a key enabler of sustainable development:}

Regional economic and environmental effects of energy transitions

\section{Cleantech als sleutel voor duurzame ontwikkeling:}

Regionale economische en milieueffecten van energietransities

(met een samenvatting in het Nederlands)

\section{Proefschrift}

ter verkrijging van de graad van doctor aan de Universiteit Utrecht op gezag van de rector magnificus, prof. dr. H.R.B.M. Kummeling, ingevolge het besluit van het college voor promoties in het openbaar te verdedigen op vrijdag 13 november 2020 des morgens te 9.15 uur

door

\section{Simon Jenniches}


Promotor:

Prof. dr. E. Worrell

Copromotor:

Dr. E.M. Fumagalli 
"There is no Planet $B$ "

(Emmanuel Macron) 


\section{Summary}

The energy sector is globally accountable for most greenhouse gas emissions and is, therefore, one of the main causes of anthropogenic global warming and climate change. Although there are many targets and strategies to reduce the emission of greenhouse gases in the energy sector, the realisation of such targets is falling behind expectations. In addition to energy efficiency, an essential mitigation strategy is to increase the use of renewable energy sources for electricity generation. Against this background, the overall goal of the thesis is to assess the economic and environmental impacts of renewable energies and to evaluate factors that support energy transitions. This will also support the decision-making process regarding a more progressive development of renewable energies.

In most OECD countries, regional authorities play major roles in the development of renewable energies. To foster the implementation of renewable energies, then, it is clearly important to study energy transitions at regional levels. Regional impact assessments in this context are tools that can be used to evaluate the effects of renewable energy developments on regional economies and provide decision support instruments for stakeholders in the field, such as politicians, administrations, and enterprises.

The thesis first studies instruments for assessing the economic impact of renewable energy developments at regional scales. The study concludes that economic models such as regional input-output tables or computable general equilibrium models are the most efficient instruments for large regions with sufficient statistical data, whereas analytical tools such as employment ratios and supply chain analysis are more suitable for small regions.

In regions with economies that rely on fossil fuels because of mining and/or activities related to energy generation, the negative impacts of the phase-out of fossil fuels must be balanced against the positive effects of investing in renewable energy sources. For the thesis, the Aachen region in Germany is chosen as an example of such a region. Of particular note is that this is also a region that acted early to address concerns regarding the development of renewable energies.

In addition to purely economic effects, the development of renewable energies and the substitution of conventional energy carriers lead to further macroeconomic benefits such as avoided greenhouse gas emissions and enhanced public health because of reductions in air pollution. The monetisation of these effects makes these macroeconomic benefits a tangible dimension for decision makers. 
Using a supply chain analysis, the impact assessment of 3.7 megawatts of photovoltaics (PV) in the district of Aachen reveals a regional value added (i.e. revenues of enterprises, net income of employees, and regionally allocated taxes) of $€ 729,000$ ( $€ 196$ per kilowatt; $€ 218$ per megawatt-hour) in 2014. For the same year, the positive effects of avoided $\mathrm{CO}_{2}$ emissions are €12,000-206,000 (€3-55 per kilowatt; €4-62 per megawatthour) and the impacts of avoided air pollution range from $€ 32,000-95,000$ ( $€ 9-25$ per kilowatt; $€ 10-28$ per megawatt-hour). Variations with respect to values found in other studies are explicable because of the differences in methodological approaches and decreases in the feed-in tariffs for PV over time. Indeed, it is expected that future PV developments in Germany will be characterised more by self-consumption of generated electricity than by feeding of electricity into the grid.

A supply chain analysis of the development of 63.1 megawatts of wind power reveals a value added of $€ 5.9$ million ( $€ 95$ per kilowatt; $€ 31$ per megawatt-hour) in 2017 in the district of Aachen. For the same year, the positive impacts of avoided $\mathrm{CO}_{2}$ emissions are $€ 13.1$ million ( $€ 208$ per kilowatt; $€ 67$ per megawatt-hour) and the impacts of avoided air pollution range from $€ 1.9-5.5$ million ( $€ 30-87$ per kilowatt; $€ 1,028$ per megawatthour). A comparison with other studies revealed that the presence of local enterprises in the wind power sector, the regional wind potential, and the decreasing feed-in tariffs have, in addition to methodological differences, a significant impact on the results.

The assessment of electricity generation prices for PV, wind power, and lignite, including the external costs of greenhouse gas emissions and air pollution, reveals that wind power is the most cost-effective electricity generation technology, followed by PV and then lignite. The cost-effectiveness of renewable energy technologies is, however, mainly due to an integration of the external costs of emitted greenhouse gas emissions. The regional employment effects are estimated at 0.63 person years per gigawatt-hour for PV, 0.17 person years for lignite and 0.08 person years for wind power. Consequently, from an environmental economic perspective, wind power is the most efficient technology, whereas from an employment perspective, PV technology is the most beneficial one. The analysis of the regional energy transition in the Aachen region further demonstrates that informal institutions such as societal interests in technological advances and environmental concerns can successfully foster the dispersion of sustainable energy generation technologies, in spite of an energy regime based on fossil fuels.

The outcomes of the thesis lead to a number of policy implications. First, as the benefits of investing in renewable energies are demonstrated, a sensible regional energy policy 
should consider a balanced energy mix based on the environmental, economic, and socioeconomic impacts of the individual energy generation technologies. In the case of the district of Aachen, both wind power and solar PV should, therefore, be part of a regional energy strategy.

As long as the cost competitiveness of renewable energies in relation to conventional energy carriers is primarily driven by the internalisation of external costs of greenhouse gas emissions, internalisation should be binding on a global level. This is necessary so that countries or regions that do not take the external costs of fossil energy generation into account do not acquire comparative advantages.

The decarbonisation of the energy sector is a challenge for regions that rely on the generation of fossil fuel energy and for incumbent utility companies relying on traditional business models. To address this, investments in education and training are needed to enable alternative job opportunities for employees in the conventional energy sector.

When discussing the energy transition, the German debate focuses mostly on electricity generation. Transforming the heating and cooling sector is not given sufficient consideration, even though this consumes a higher share of energy in this country. Further policies should take into account an integrated approach and consider the electricity, heating and cooling, and transport sectors as an interconnected system. Furthermore, policies should ideally address specific regional aspects in terms of formal and informal institutions. In the Aachen region, for example, where a strong interest in technologies and environmentalism is rooted in the regional culture, sharing up-to-date information regarding renewable energy developments is suggested as a useful instrument for supporting the transition in the region. This serves to build up a knowledge infrastructure that fosters the dissemination of renewable energy technologies.

In addition to analysing energy transitions at national levels, future research should pay greater attention to regions and comprehensively account for the impacts of renewable energy developments on the economy and the environment. In addition, an increasing amount of intermittent renewable energies will require that grid and storage solutions are also considered. Therefore, future research should also pay more attention to developments in emerging economies where energy demand is expected to rise considerably and the diffusion of renewable energies has the potential to foster a more sustainable economic growth. 


\section{Samenvatting}

Wereldwijd is de energiesector verantwoordelijk voor de meeste broeikasgasemissies. Daarmee is de energiesector één van de belangrijkste veroorzakers van de antropogene opwarming van de aarde en klimaatverandering. Hoewel er veel ambities en strategieën zijn om de uitstoot van broeikasgassen in de energiesector te verminderen, blijft de realisatie van dergelijke doelstellingen achter bij de verwachtingen. Naast energieefficiëntie is het gebruik van hernieuwbare energiebronnen voor de opwekking van elektriciteit een essentiële strategie. Tegen deze achtergrond is het algemene doel van het proefschrift om de economische effecten en milieueffecten van hernieuwbare energieën te beoordelen en de ondersteunende factoren van energietransities te evalueren. Dit zal op zijn beurt het besluitvormingsproces met betrekking tot een meer progressieve ontwikkeling van hernieuwbare energieën ondersteunen.

In de meeste OESO-landen spelen regionale autoriteiten een belangrijke rol bij het opwekken van hernieuwbare energie. In tegenstelling tot huidige centrale opwekkingstechnologie, worden veel hernieuwbare energieopwekkingstechnologiën decentraal geïmplementeerd. Om de implementatie van hernieuwbare energieën te bevorderen is het van belang om de energietransities op regionaal niveau te bestuderen. In dit verband zijn regionale effectbeoordelingen een instrument die kunnen worden gebruikt om de effecten van de ontwikkelingen op het gebied van hernieuwbare energie op de regionale economie te evalueren en een beslissingsondersteunend instrument te vormen voor belanghebbenden in het veld, zoals politici, de overheid of bedrijven.

In het proefschrift worden eerst het bestaande onderzoek en onderzoeksmethodes beschreven naar economische effectbeoordelingsinstrumenten voor ontwikkelingen op het gebied van hernieuwbare energie op regionale schaal, waarbij wordt geconcludeerd dat economische modellen zoals regionale input-outputtabellen of berekenbare algemene evenwichtsmodellen de meest efficiënte instrumenten zijn voor grote regio's met voldoende statistische gegevens, terwijl voor kleine regio's analytische instrumenten zoals werkgelegenheidsratio's en de analyse van de toeleveringsketen geschikter zijn.

In regio's die economisch afhankelijk zijn van fossiele brandstoffen vanwege b.v. mijnbouw- en/of fossiele energieopwekkingsactiviteiten, moeten de negatieve effecten van de uitfasering van fossiele brandstoffen worden afgewogen tegen de positieve effecten van investeringen in hernieuwbare energiebronnen. In het proefschrift wordt de regio Aken in Duitsland gekozen als voorbeeld van een 
dergelijke regio. Dit was ook een early mover regio voor wat betreft de ontwikkeling van hernieuwbare energiebronnen.

Naast de zuiver economische effecten leidt de ontwikkeling van hernieuwbare energiebronnen en de vervanging van conventionele energiedragers tot verdere macro-economische voordelen, zoals minder broeikasgasemissies en een betere volksgezondheid door een vermindering van de luchtvervuiling. De monetarisering van deze effecten maakt deze macro-economische voordelen tot een tastbare dimensie voor besluitvormers.

Op basis van een analyse van de toeleveringsketen (supply chain analysis) blijkt uit de effectbeoordeling van 3,7 MW aan PV in de Städteregion Aken dat de regionale toegevoegde waarde (d.w.z. inkomsten van ondernemingen, netto-inkomsten van werknemers en regionaal toegewezen belastingen) in 2014729.000 euro bedraagt ( 196 euro/kW, 218 euro/MWh). De positieve effecten van niet uitgestoten $\mathrm{CO}_{2}$-emissies zijn $€ 12.000-206.000$ ( $€ 3-55$ per kW, €4-62 per MWh) en de effecten van minder luchtverontreiniging variëren van $€ 32.000-95.000$ (€9-25 per kW, €10-28 per MWh) in hetzelfde jaar. Variaties ten opzichte van de waarden die in andere studies zijn gevonden, zijn verklaarbaar door verschillen in methodologische benaderingen en afnemende teruglevertarieven voor PV. De verwachting is dat de toekomstige ontwikkelingen op het gebied van PV in Duitsland meer gekenmerkt zullen worden door het eigenverbruik van opgewekte elektriciteit dan door het terugleveren van elektriciteit aan het net.

Een supply chain-analyse van de ontwikkeling van $63,1 \mathrm{MW}$ aan windenergie toont een toegevoegde waarde van $€ 5,9$ miljoen ( $€ 95 / \mathrm{kW}, € 31 / \mathrm{MWh}$ ) in 2017 in de Städteregion Aken. De positieve effecten van de niet uitgestoten $\mathrm{CO}_{2}$-emissies bedragen 13,1 miljoen euro (208 euro per kW, 67 euro per MWh) en de effecten van de verminderde luchtverontreiniging variëren van 1,9 miljoen euro tot 5,5 miljoen euro (30-87 euro per $\mathrm{kW}, 108$ euro per $\mathrm{MWh}$ ) in datzelfde jaar. Uit een vergelijking met andere studies blijkt dat de aanwezigheid van lokale bedrijven in de windenergiesector, het regionale windenergiepotentieel en de dalende feed-in-tarieven, naast methodologische verschillen, een aanzienlijke invloed hebben op de resultaten.

De beoordeling van de prijzen van de elektriciteitsproductie van PV, windenergie en bruinkool, met inachtneming van de externe kosten van de uitstoot van broeikasgassen en luchtverontreiniging, toont aan dat windenergie de meest kosteneffectieve technologie voor de opwekking van elektriciteit is, gevolgd door PV en bruinkool. De kosteneffectiviteit van hernieuwbare energietechnologieën is echter vooral te danken 
aan een integratie van de externe kosten van de uitstoot van broeikasgassen. De regionale werkgelegenheidseffecten worden geschat op 0,63 persoonsjaren per $\mathrm{GWh}$ voor PV, 0,17 persoonsjaren voor bruinkool en 0,08 persoonsjaren voor windenergie. Bijgevolg is windenergie vanuit milieu-economisch oogpunt de meest efficiënte technologie, terwijl PV vanuit werkgelegenheids-perspectief de meest gunstige is.

De analyse van de regionale energietransitie in de regio Aken toont verder aan dat informele instellingen, zoals de maatschappelijke instituten/actoren die werken aan technologische vooruitgang en milieubelangen, met succes de verspreiding van duurzame energietechnologie kunnen bevorderen, ondanks een energieregime op basis van fossiele brandstoffen.

De uitkomsten van het proefschrift leiden tot een aantal beleidsimplicaties. Ten eerste, aangezien de voordelen van investeringen in hernieuwbare energiebronnen worden aangetoond, moet een verstandig regionaal energiebeleid een evenwichtige energiemix overwegen, gebaseerd op de ecologische, economische en sociaaleconomische effecten van de afzonderlijke technologieën voor energieopwekking. In het geval van de Städteregion Aken moeten zowel windenergie als zon-PV daarom deel uitmaken van een regionale energiestrategie.

Zolang het kostenconcurrentievermogen van hernieuwbare energiebronnen ten opzichte van conventionele energiedragers vooral wordt bepaald door de internalisering van de externe kosten van de uitstoot van broeikasgassen, zou een dergelijke internalisering op mondiaal niveau bindend moeten zijn. Dit is nodig om te voorkomen dat landen of regio's die geen rekening houden met de externe kosten van de opwekking van fossiele energie, een comparatief voordeel krijgen (carbon leakage).

Het koolstofvrij maken van de energiesector is een uitdaging voor regio's die afhankelijk zijn van de opwekking van energie uit fossiele brandstoffen en voor gevestigde nutsbedrijven die afhankelijk zijn van traditionele bedrijfsmodellen. In dit verband zijn investeringen in onderwijs nodig om alternatieve werkgelegenheid voor werknemers in de conventionele energiesector mogelijk te maken.

Bij de discussie over de energietransitie richt het Duitse debat zich vooral op de elektriciteitsproductie. Het transformeren van de warmte- en koelingsector wordt onvoldoende in overweging genomen, hoewel dit een groter aandeel van de energie verbruikt. In het verdere beleid moet een geïntegreerde aanpak worden overwogen en moet de elektriciteits-, warmte-, koel- en transportsector als een 
onderling verbonden systeem worden beschouwd. Bovendien zou het beleid idealiter rekening moeten houden met specifieke regionale aspecten, in termen van formele en informele instellingen. In de regio Aken bijvoorbeeld, waar een grote belangstelling voor technologieën en milieubewustzijn in de regionale cultuur is geworteld, is het delen van actuele informatie over de ontwikkelingen op het gebied van hernieuwbare energie voorgesteld als een nuttig instrument om de overgang in de regio te ondersteunen. Dit dient om een kennisinfrastructuur op te bouwen die de verspreiding van duurzame energietechnologie bevordert.

Naast de analyse van de energietransitie op nationaal niveau dient in toekomstige onderzoek meer aandacht worden besteed aan regio's en dient uitvoerig rekening worden gehouden met de gevolgen van de ontwikkelingen op het gebied van hernieuwbare energie voor de economie en het milieu. Bovendien zal voor een toenemend aantal intermitterende hernieuwbare energieën ook rekening moeten worden gehouden met net- en opslagoplossingen. Ten slotte dient in het toekomstige onderzoek meer aandacht worden besteed aan opkomende economieën, waar de vraag naar energie naar verwachting aanzienlijk zal toenemen en de verspreiding van hernieuwbare energie het potentieel heeft om duurzamere economische groei te bevorderen. 


\section{Contents}

List of Abbreviations $\quad 16$

1 Introduction 23

1.1 Energy generation and climate change mitigation $\quad 24$

1.2 The motivation for regional energy transitions 27

$\begin{array}{lll}1.3 & \mathbf{2 9}\end{array}$

$1.4 \quad$ Objectives of the thesis and research questions $\quad 34$

$1.5 \quad 37$

$2 \quad$ Assessing the Regional Economic Impacts of Renewable Energy 41

Sources - A Literature Review

2.1 Introduction $\quad 43$

$\begin{array}{lll}2.2 & \text { Process of literature selection } & \mathbf{4 6}\end{array}$

2.3 Evaluated regions, technologies, impacts and time periods $\quad \mathbf{4 8}$

2.3.1 Regions covered by the reviewed publications $\quad \mathbf{4 8}$

2.3.2 Technologies covered by the reviewed publications $\quad \mathbf{5 0}$

2.3.3 Economic impact indicators assessed by the reviewed publications $\mathbf{5 2}$

2.3.4 Time periods analysed in the reviewed publications $\mathbf{5 9}$

$2.4 \quad$ Evaluation of methods $\quad 62$

2.4.1 Employment ratios $\quad 62$

$\begin{array}{lll}2.4 .2 & \text { Supply chain analysis } & \mathbf{6 2}\end{array}$

$\begin{array}{lll}2.4 .3 & \mathbf{6} & \mathbf{6 8}\end{array}$

2.4.4 Computable general equilibrium models $\quad \mathbf{7 3}$

2.4.5 Other methods $\quad 76$

2.5 Guideline towards regional RE impact assessment 77

3 Regional Economic and Environmental Impacts of Renewable 87

Energy Developments: Solar PV in the Aachen Region

$\begin{array}{lll}3.1 & \mathbf{8 9}\end{array}$

3.2 Characteristics of the region and PV developments in the region 90

3.3 Regional economic impacts of PV 92

3.3.1 Selection of an impact assessment method 92

3.3.2 Assessing the regional economic impact of PV 94

$\begin{array}{lll}\text { 3.3.3 Results } & 106\end{array}$

3.3.4 Comparison of the results to other studies in the field $\mathbf{1 1 1}$

$\begin{array}{lll}\text { 3.4 Estimating the impact of PV on avoided greenhouse gas emissions } & \mathbf{1 1 5}\end{array}$ and air pollution

$\begin{array}{lll}\text { 3.4.1 Avoided GHG emissions due to PV deployment } & \mathbf{1 1 5}\end{array}$

3.4.2 Avoided air pollutant effects and their economic impact $\quad \mathbf{1 1 7}$

$\begin{array}{ll}3.5 & \mathbf{1 1 9}\end{array}$ 
4 Regional Economic and Environmental Impacts of Wind Power

Developments: A Case Study of a German Region

$\begin{array}{lll}4.1 & 125\end{array}$

$\begin{array}{lll}4.2 & \text { Characteristics of the region and wind power developments } & 127\end{array}$

4.3 Regional economic impacts of wind power $\quad 129$

4.3.1 Selection of an assessment methodology 129

$\begin{array}{lll}\text { 4.3.2 Lifecycle analysis and estimation of economic activities carried out in } & \mathbf{1 3 0}\end{array}$ the region

4.3.3 Calculation of effects 133

$\begin{array}{lll}\text { 4.3.4 Results } & 141\end{array}$

4.3.5 Comparison of the results with existing studies $\quad \mathbf{1 4 3}$

4.4 Impacts of wind power on GHG emissions and air pollution $\quad \mathbf{1 4 9}$

4.4.1 Methodology to assess the impacts of wind power on GHG emissions $\quad \mathbf{1 4 9}$ and air pollution

$\begin{array}{lll}\text { 4.4.2 } & \mathbf{1 5 0}\end{array}$

4.4.3 Avoided air pollution and its economic impact $\quad \mathbf{1 5 2}$

4.4.4 Comparison of the results with existing studies $\quad 153$

4.5 Conclusion and Policy Implications 155

5 Energy transitions at the subnational scale: How to get the former 161

German frontrunner region Aachen back on track

$\begin{array}{lll}5.1 & 163\end{array}$

$\begin{array}{lll}5.2 & \text { The multi-level perspective } & 167\end{array}$

$\begin{array}{lll}\text { 5.2.1 The regional variation of niches } & 167\end{array}$

$\begin{array}{lll}\text { 5.2.2 A multi-scalar view on socio-technical regimes } & \mathbf{1 6 8}\end{array}$

$\begin{array}{ll}\text { 5.2.3 Socio-technical landscape level } & \mathbf{1 6 9}\end{array}$

$\begin{array}{lll}5.3 & \mathbf{1 6 9}\end{array}$

5.4 Managing the energy transition in the Aachen region $\quad \mathbf{1 7 0}$

$\begin{array}{lll}\text { 5.4.1 Regime dynamics } & \mathbf{1 7 0}\end{array}$

$\begin{array}{lll}\text { 5.4.2 Renewable niche innovations } & 173\end{array}$

$\begin{array}{lll}\text { 5.4.3 Summary of findings } & \mathbf{1 8 1}\end{array}$

5.5 Conclusion, policy implications, and recommendations for future $\quad \mathbf{1 8 3}$ research

6 Conclusion $\quad 187$

$\begin{array}{lll}6.1 & \text { Summary of the results } & \mathbf{1 8 8}\end{array}$

$\begin{array}{lll}6.2 & \text { Policy implications } & 194\end{array}$

$\begin{array}{ll}\text { 6.3 Recommendations for further research } & 196\end{array}$

References $\quad 200$

$\begin{array}{ll}\text { Acknowledgements } & \mathbf{2 4 0}\end{array}$

About the Author $\quad 242$ 


\section{List of Abbreviations}

AGIT Aachener Gesellschaft für Innovation und Technologietransfer (Innovation and Technology Transfer Agency Aachen)

ARD Arbeitsgemeinschaft der öffentlich-rechtlichen Rundfunkanstalten der Bundesrepublik Deutschland (Working group of public broadcasters of the Federal Republic of Germany)

ARL Akademie für Raumforschung und Landesplanung (Academy for Spatial Research and Planning)

BEA Bureau for Economic Analysis

BMBF Bundesministerium für Bildung und Forschung (German Federal Ministry of Education and Research)

BMU Bundesministerium für Umwelt, Naturschutz und nukleare Sicherheit (German Federal Ministry of the Environment, Nature Conservation and Nuclear Safety)

BMVBS Bundesministerium für Verkehr, Bau und Stadtentwicklung (German Federal Ministry of Transport, Building and Urban Development)

BMVI Bundesministerium für Verkehr und digitale Infrastruktur (German Federal Ministry of Transport and Digital Infrastructure)

BMWi Bundesministerium für Wirtschaft und Energie (German Federal Ministry for Economic Affairs and Energy)

bn billion

BUND Bund für Umwelt und Naturschutz Deutschland (German Federation for the Environment and Nature Conservation)

BWE Bundesverband Windenergie (German Wind Energy Association)

C carbon

C cent

CA California

CGE computable general equilibrium

$\mathrm{CH}_{4} \quad$ methane

CHP combined heat and power

CO carbon monoxide

$\mathrm{CO}_{2}$ carbon dioxide

$\mathrm{CO}_{2}$-eq carbon dioxide equivalents

CSP concentrated solar power 


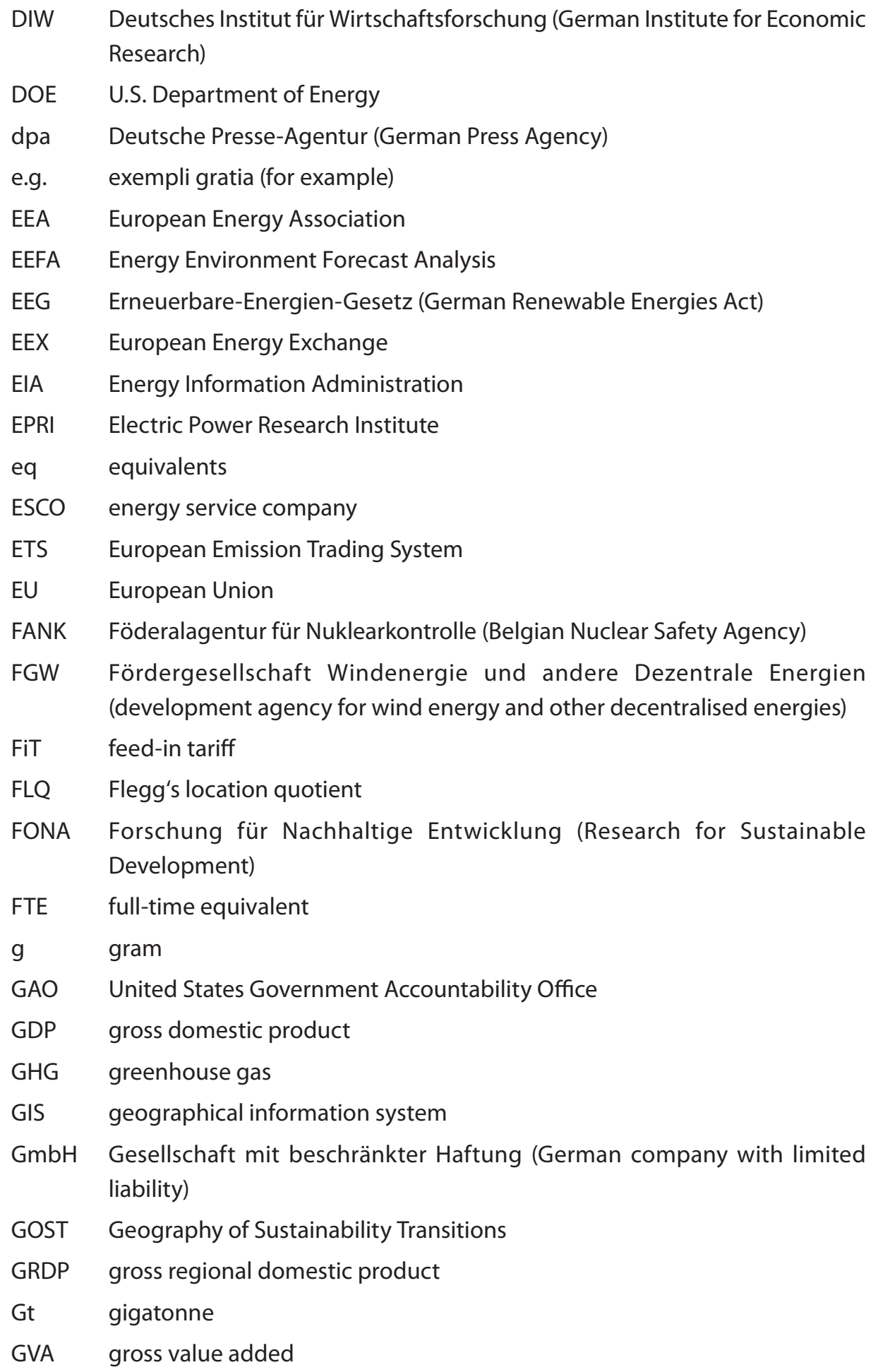




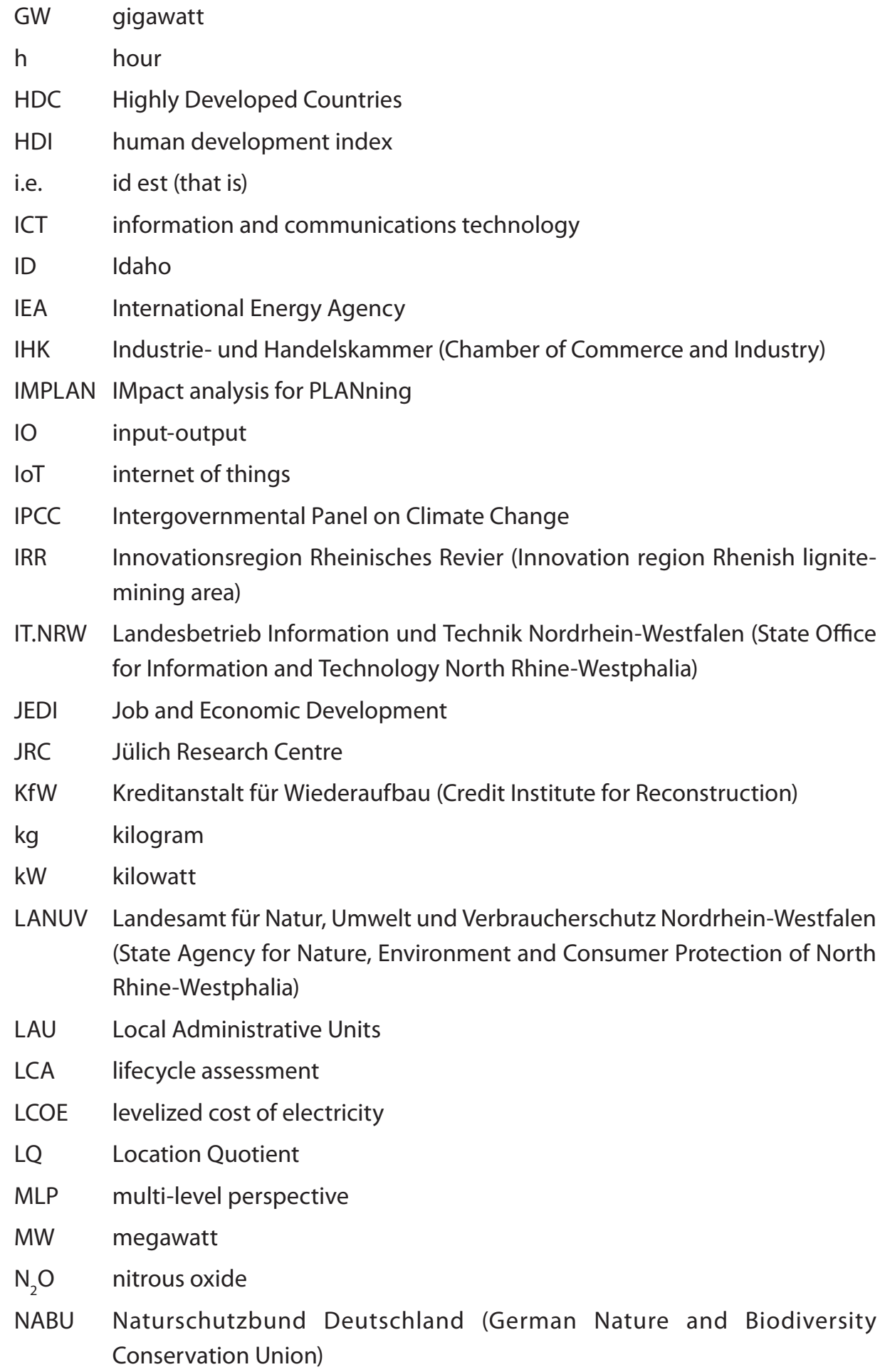

IT.NRW Landesbetrieb Information und Technik Nordrhein-Westfalen (State Office for Information and Technology North Rhine-Westphalia)

JEDI Job and Economic Development

JRC Jülich Research Centre

KfW Kreditanstalt für Wiederaufbau (Credit Institute for Reconstruction)

kg kilogram

kW kilowatt

LANUV Landesamt für Natur, Umwelt und Verbraucherschutz Nordrhein-Westfalen (State Agency for Nature, Environment and Consumer Protection of North Rhine-Westphalia)

LAU Local Administrative Units

LCA lifecycle assessment

LCOE levelized cost of electricity

LQ Location Quotient

MLP multi-level perspective

MW megawatt

$\mathrm{N}_{2} \mathrm{O} \quad$ nitrous oxide

NABU Naturschutzbund Deutschland (German Nature and Biodiversity Conservation Union) 
NASA National Aeronautics and Space Administration

NDP net domestic product

NMVOCs non-methane volatile organic compounds

$\mathrm{NO}_{x} \quad$ nitrogen oxides

NREL National Renewable Energy Laboratory

NRW North Rhine-Westphalia

NUTS Nomenclature des Unités Territoriales Statistiques (Classification of Territorial Units for Statistics)

O\&M operation and maintenance

OECD Organisation for Economic Co-operation and Development

OEM Original Equipment Manufacturer

PM Particulate Matter

PV photovoltaic

$R \& D \quad$ research and development

rbb Rundfunk Berlin-Brandenburg (Berlin-Brandenburg Broadcasting)

$\mathrm{RE} \quad$ renewable energy

REN21 Renewable Energy Policy Network for the 21st Century

render regionaler Dialog Energiewende (regional dialogue energy transition)

REPP Renewable Energy Policy Project

RES renewable energy sources

RIMS Regional Input-Output Modelling System

RIOT Regional Input-Output Table

RISP Rhein-Ruhr-Institut für Sozialforschung und Politikberatung (Rhine-RuhrInstitute for Social Research and Policy Consulting)

$\mathrm{RQ}$ research question

RWE Rheinisch-Westfälisches Elektrizitätswerk Aktiengesellschaft (RhenishWestphalian Electric Power Company)

RWTH Rheinisch-Westfälische Technische Hochschule Aachen (Rhenish-Westphalian University of Technology)

s.a. $\quad$ sine anno (without year)

SAM social accounting matrix

SCC social cost of carbon

SDG Sustainable Development Goal

SE Societas Europaea (European company) 
SEED Sustainable Energy and Economic Development

SFV solar photovoltaic initiative (Solarenergieförderverein)

SME small and medium-sized enterprise

$\mathrm{SO}_{2} \quad$ sulphur dioxide

SOA secondary organic aerosols

$\mathrm{t}$ ton

TW terrawatt

UBA Umweltbundesamt (German Environment Agency)

UK United Kingdom of Great Britain and Northern Ireland

UN United Nations

UNDP United Nations Development Programme

UNEP United Nations Environment Programme

UNFCCC United Nations Framework Convention on Climate Change

US United States of America

VOLY value of a life year

VSL value of a statistical life

WACC Weighted Average Cost of Capital

wdl working days lost

WEBEE Modell zur Ermittlung von Wertschöpfungs- und Beschäftigungseffekten durch Erneuerbare Energien (Assessment model for value added and employment effects of renewable energies)

WFG Wirtschaftsförderungsgesellschaft (Economic Development Agency)

WHO World Health Organization

wtp willingness to pay

YOLL years of life lost

ZSW Zentrum für Sonnenenergie- und Wasserstoff-Forschung BadenWürttemberg (Center for Solar Energy and Hydrogen Research BadenWürttemberg)

$€ \quad$ Euro

\$ Dollar 

Introduction 


\subsection{Energy generation and climate change mitigation}

"Doing all we can to combat climate change comes with numerous benefits, from reducing pollution and associated health care costs to strengthening and diversifying the economy by shifting to renewable energy, among other measures."

(David Suzuki)

This statement by the Canadian environmental activist David Takayoshi Suzuki illustrates that climate change mitigation strategies may lead to positive impacts for the environment, society, and the economy. Assessing these impacts on a regional scale is the aim of this thesis. However, which sector has the greatest potential for climate change mitigation? Also, why is it important to evaluate the effects on a subnational scale?

It is widely accepted by climate scientists that there exists an undeniable correlation between greenhouse gas (GHG) emissions produced by anthropogenic (i.e. industrial, household or traffic) activities and global warming causing climate change effects with severe impacts on ecosystems. Examples of these impacts, which affect the ecological balance of the earth, are droughts and desertification, melting polar icecaps that lead to higher sea levels and flooding, or a loss in biodiversity (Oreskes, 2004; NASA, 2020; Solomon et al., 2009; Karl and Trenberth, 2003).

As a political response, the international community has agreed to limit global warming to a temperature below " 2 degrees Celsius above pre-industrial levels and to pursue efforts to limit the temperature increase even further to 1.5 degrees Celsius" (UNFCCC, 2020), according to the Paris Agreement in 2016. All 186 signing parties committed to undergo determined endeavours regarding climate change mitigation and adaptation (UNFCCC, 2020). However, even since that time, fossil carbon dioxide $\left(\mathrm{CO}_{2}\right)$ emissions have been steadily rising on a global scale (Crippa et al., 2019). As a consequence, climate change mitigation strategies leading to decreases in emissions are urgently needed.

However, numerous climate policy opponents around the globe share and spread the view that mitigation strategies such as the phase-out of fossil fuels and investing in energy efficiency and renewable energy developments induce negative effects for the economy (Brunnengräber, 2013; Hopkin, 2007). This strong emphasis on negative effects is a barrier to the implementation of climate change policies that include comprehensive strategies for mitigation (Lorenzoni, et al., 2007; Dunlap and McCright, 2011). It is, therefore, the responsibility of science to conduct thorough and 
objective assessments of the impacts that climate change mitigation measures have on the economy and the environment. Science must then also provide a basis for sound decision-making for stakeholders (e.g. decision makers involved in politics, administration, or the economy) who are wrestling with choices about whether to invest further in fossil fuels or to initiate the transformation into a low carbon economy (Dunlap, 2013).

Assessing the effects of climate change mitigation strategies is, however, complex as it may involve various sources of emissions, all with distinguished economic characteristics and environmental impacts. Therefore, to assess the impact of climate change mitigation measures, we need to specify the topics that are targeted by the thesis in greater detail.

We find that different sectors (e.g. transport, electricity generation, or buildings) all have individual characteristics and specific GHG emissions. Figure 1.1 illustrates the share of $\mathrm{CO}_{2}$ emissions per sector on a global level. $\mathrm{CO}_{2}$ is the most important $\mathrm{GHG}$ and accounted for $74 \%$ of GHG emissions globally in 2015 (Crippa et al., 2019). Nearly half of the $\mathrm{CO}_{2}$ emissions (41\%; 13.6 gigatons (Gt)) in 2017 were caused by electricity and heat generation, which accounts for the largest amount of emissions per sector. 


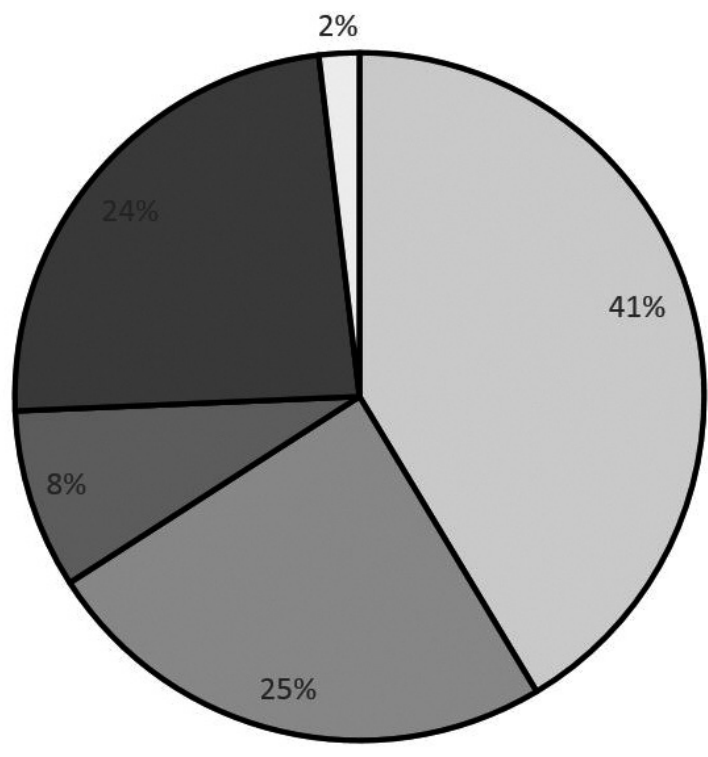

\section{$\boldsymbol{\square}$ Electricity and heat $\boldsymbol{\square}$ Transport $\boldsymbol{\square}$ Buildings $\boldsymbol{\square}$ Industry $\boldsymbol{\square}$ Other}

Figure 1.1: Share of $\mathrm{CO}_{2}$ emissions per sector on a global level in 2017 (total emissions: 32.8 Gt) (Source: IEA, 2019)

Against this background, reducing GHGs, especially in the energy sector, is essential for effectively combatting climate change. Moreover, there is a huge technical potential in decarbonising this sector (Schmidt et al., 2012; Jägemann et al., 2013). The importance of the energy sector is also underlined by the United Nations Development Programme (UNDP), as it has positioned "affordable and clean energy" (UNDP, 2019) as a Sustainable Development Goal (SDG). A key strategy in achieving this goal is to "increase substantially the share of renewable energy in the global energy mix" (UNDP, 2019), as energy generation by renewable energy sources induces significantly fewer GHGs than energy generated by conventional fossil energy carriers (Memmler et al., 2014).

Consequently, there is a need to determine the effects of transforming the conventional energy system by moving toward renewable energy sources, where the focus of this 
thesis lies on electricity generation. The spatial scale to assess these effects efficiently and to manage this transformation effectively is illustrated in the following text.

\subsection{The motivation for regional energy transitions}

Globally, we find a wide range of policy targets that are embedded in national climate change mitigation strategies, such as setting objectives for reducing GHG emissions by 2030 at $11 \%$ for New Zealand, 25-30\% for Russia, and 40\% in the European Union (EU), in comparison to 1990 (Carbon Brief, s.a.). However, according to the recent Emissions Gap Report of the United Nations Environment Programme (UNEP, 2019), there is a significant discrepancy between the emission mitigation targets that have been set by the United Nations in treaties such as the Kyoto Protocol (Umweltbundesamt, 2013) or the Paris Agreement (UNFCCC, 2020) and the actual achievements of these goals (UNEP, 2019). Because of this discrepancy between the objectives and targets and the climate mitigation actions and achievements of the individual countries, a more effective approach is needed with regard to climate mitigation policies.

In most countries that are part of the Organisation for Economic Co-operation and Development (OECD), regional or local authorities possess wide-ranging autonomies in terms of land management (Silva and Acheampong, 2015). For example, these authorities decide on land use for large-scale renewable energy developments such as wind power or open field solar photovoltaics (PV). As a consequence, to achieve a national mitigation target, regional authorities have to allow land use for the development of renewable energies. To accomplish this, a pragmatic and presumably fair strategy would be to break down and adopt national regulations such as specific shares of energy generated by renewable energy sources in the amounts of energy used for individual spatial entities (e.g. a state or region). However, from a practical perspective, this poses a lot of challenges. Distinctive physical geographic situations such as available land and solar, wind, or biomass potential and specific characteristics like political willingness have to be considered. In terms of its geography, a region may be characterised by densely populated urban areas, where certain renewable energy technologies such as large wind turbines may be difficult to develop because of, for example, minimal distance regulations to residential areas (Meyerhoff et al., 2010) or biomass, since biotic material may not be sufficiently available. In cases where there is sufficient solar irradiation, the deployment of rooftop PV may offer a more suitable solution for these regions. However, due to the relatively low energy intensity per area for PV, which is lower, for example, than for wind power (Landt and Kjaer, s.a.), the envisaged share of energy generated by renewable sources may not be achievable 
solely by using PV. Therefore, such a region would need to rely on power imports from other regions and might not be able independently to achieve a renewable energy target derived from its national threshold. In contrast, in regions that have a low population density and only a few dispersed residential areas but have sufficient wind potential, wind power developments are the most efficient option. ${ }^{1}$ These regions may eventually even be able to exceed a national renewable energy threshold and compensate for the underperformance of regions with low physical geographic potentials. Hence, targets should be formulated for regions on an individual basis with regard to their specific potentials for renewable energy generation.

In terms of land management, we generally observe, especially in regions with a high population density, conflicting interests between space for renewable energy developments and space for built environment, farmland, or recreational space (Warren et al., 2005; Steinhäußer et al., 2015). These conflicts are especially challenging in democratic and pluralistic societies where decision-making processes around land planning are usually based on public consent (Walker, 1995). Projects that are perceived critically or are not popular with those in the field, such as politicians, the administration, or citizens, may eventually not be realised (Enevoldsen and Sovacool, 2016; Ogilvie and Rootes, 2015). In contrast, economic and environmental benefits positively affect stakeholders' opinions about the development of renewable energies and are, therefore, supportive factors for energy transitions. Mulvaney et al. (2013), for example, state that the positive economic impacts of wind power, especially in rural regions of the United States, were a major supporting factor, which confirms the results of Slattery et al. (2011). Yuan et al. (2015), find that positive environmental impacts such as reductions in GHG emissions and pollution were perceived by local residents in the Chinese region of Shandong as being the main benefits of developing wind power. Similar results were found by Fokaides et al. (2014), who show the contribution of wind power as an energy source for reducing "environmental pollution created from the imported fossil fuels" (Fokaides et al., 2014:487) to be a supportive factor for wind power developments among local residents in the Greek Island of Cyprus.

In summary, we see first that, as decisions on renewable energy developments are taken on regional or local levels in many countries, regional strategies are explicitly needed to close the gap between national emission reduction and actual achievements. The national energy transition is, except in very small countries such

1 This is a simplified assumption concerning the legal aspects about the development of wind power as they include further regulations in most countries, such as nature conservation, distance to residential areas, etc. 
as Luxembourg or Cyprus, only the sum of the regional energy transitions. Second, in pluralistic societies, energy transformation rests on political willingness and social consent, which depend on the perceived overall benefits of transitions.

The overall goal of the thesis is, therefore, to assess the economic and environmental impacts of energy transitions on a regional scale to provide a sound base for regional decision makers. Moreover, additional supportive factors for regional transition processes are elaborated in order to foster regional energy transformations more efficiently.

\subsection{Introducing a reference region}

On a global scale, we see energy demands increasing in developing economies, whose primary energy consumption is expected to rise to $65 \%$ of the world energy consumption by 2040, while in 2010 the amount of energy consumption among OECD countries accounted for $46 \%$ even though only 30 of the world's 193 countries are member states of the OECD (EIA, 2013).

Energy consumption in countries rises because of economic development processes, such as increases in export oriented industrial activities or domestic household consumption, and this leads to increasing demands for goods that are produced inside or outside the country. It should, then, be considered that, from the point of view of fairness, developing and emerging countries have the right to develop their economies and therefore have a certain legitimisation with regard to emitting GHGs through production or inducing GHGs by consumption (Wei et al., 2014; Bastianoni et al., 2004). ${ }^{2}$ As a consequence, highly developed countries (HDC) ${ }^{3}$, particularly those that have historically emitted vast amounts of GHGs and, some of which have done so since the beginning of the industrial revolution, and still emit a disproportional amount of GHGs, have a special responsibility as well as the technological and financial capability to reduce emissions (Neumayer, 2000; Ding et al., 2009). The thesis, therefore, focuses mainly on countries within this group, with a particular emphasis on Germany.

Germany is a frontrunner in energy transition, not only because of the development of renewable energy support schemes there but also in terms of technological developments regarding, for example, PV and wind power (Quitzow et al., 2016).

2 In this regard, using energy generated by renewable energy sources is desirable.

3 The definition of HDC is based on the human development index (HDI) as an indicator for the development of a country. The HDI has been criticised as issues like sustainability or social cohesion, for example, are not extensively considered in the concept (Bilbao-Ubillos, 2013). 
However, in terms of reducing GHG emissions, the country will presumably not achieve its 2020 target of reducing such emissions by $40 \%$ in comparison to 1990 (Presse- und Informationsamt der Bundesregierung, 2019). Even though the share of renewables in terms of the total gross electricity generated increased from 15\% in 2008 to $38 \%$ in 2018 (Umweltbundesamt, 2019a), the country still relies on lignite, which is responsible for the highest share of emissions in the electricity sector and was accountable for $22 \%$ of gross electricity generation in 2018 (Umweltbundesamt, 2019b; Oei et al., 2019). Given the achievements to date, as well as the technological capabilities to accomplish the emission reduction goals (Kopiske and Gerhard, 2018), the German context provides an exemplary frame with regard to developed countries for assessing the impacts of the energy transition and studying how it can be supported on regional levels. Indeed, the energy transition does not imply only a technical transition by a simple fuel switch to non-fossil energy carriers, since the process induces vast economic, environmental, social, and political changes.

Some regions have not historically been able to take part in the energy generation sector because of, for example, a lack of resources, mainly those for transport-intensive goods such as coal or lignite where energy generation usually takes place in close proximity to mineral deposits because of transport costs. Yet, these regions can manage to take part in this (new) economic activity through the development of renewable energies. One example of such a region is the economically less favoured North German federal state of Schleswig-Holstein where, in 2016, 18\% of Germany's wind power was generated even though the region covers only $4 \%$ of the surface of Germany (Agentur für Erneuerbare Energien, s.a.a). These developments also provide opportunities for income and employment because the manufacturing of wind turbine components take place in the region (Ulrich and Lehr, 2018; Bröcker et al., 2014). In contrast, other regions that have historical dependence on the conventional energy sector, such as the Lausitz or the Rhenish lignite mining region, are expected to experience economic downturns in some industries, including mining and conventional energy generation, because of the phase-out of fossil fuels (Hermann et al., 2018). This thesis will focus particularly on regions facing economic challenges, such as mining regions, as they are expected to be more negatively affected than others by the energy transformation. Consequently, if it is possible to demonstrate the economic feasibility of the energy transformation in regions that are currently expected to be negatively affected, the net positive impacts may be even higher in less affected regions. Therefore, the type of region discussed in this thesis can be regarded as an extreme example, while the lessons learned will be transferable to regional energy transformations in general. 
An ideal example for illustrating a regional energy transformation that is affecting the economy and the environment is the Aachen region in the West German federal state of North Rhine-Westphalia. This region has a physical geographical potential that includes space, solar irradiation and wind for electricity generation by PV and wind power. These potentials may be rated as medium quality, since there are regions with more or less favourable potentials for both technologies in Germany, which makes the region a good example of an average region in the country.

Before describing the region's characteristics, we have to discuss the concept of a region. Traditionally, geographers distinguish between different types of regions. First, the administrative region within defined borders, typically at a subnational level, has a political-administrative character. An example may be a federal state or a district (Benz et al., 1999). Second, there is the functional region, which is composed mainly of economic interrelations in space (Juillard, 1962; Brown and Holmes, 1971). Examples of functional regions are commuting catchment areas. The third type is the structural region, a geographical area with a similar economic structure such as a mining region (Spektrum, 2001). In our description of the Aachen region, we take into account two of these different dimensions: the administrative and the structural region. The administrative region of the district of Aachen (German: Städteregion Aachen) is the fundamental scale for the evaluation of regional characteristics such as economic analysis, population surveys or energy system analysis. In 2018, the district covers an area of $707 \mathrm{~km}^{2}$ with a population of approximately 555,000 inhabitants (IT.NRW, 2020).

With regard to the economic situation, $0.6 \%$ (€19 billion (bn) in total) of the gross value added $^{4}$ of Germany $(€ 2,922$ bn in total) is generated in the district of Aachen (Figure 1.2). The distribution of sectors in terms of the shares of the total value added reveals a specialisation in the mining and quarrying sector and the energy and water sector ( $5 \%$ of gross value added) in the district of Aachen, in comparison to Germany as a whole ( $3 \%$ of gross value added). Moreover, we see a specialisation in terms of the value added in public services, education and health, and miscellaneous services of $27 \%$ in the district of Aachen and $22 \%$ in Germany.

4 The gross value added is defined as Output - Intermediate Inputs = GVA(P) (production approach) or with the income approach as Compensation of Employees + Gross Operating Surplus + Mixed Income + Taxes on Production - Subsidies on Production = GVA(I) (Office for National Statistics, s.a.) 


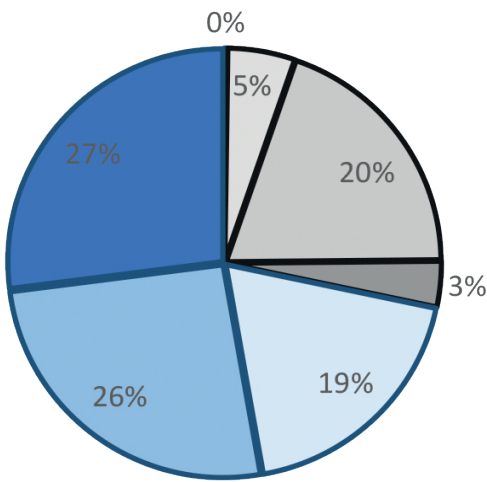

District of Aachen (Total: $€ 19$ bn)

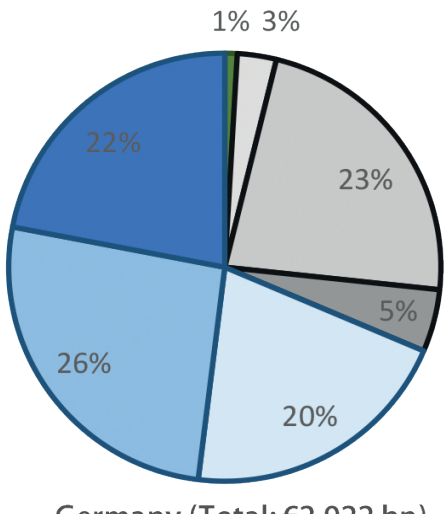

Germany (Total: $€ 2,922$ bn)

$\square$ Agriculture, forestry, and fishing

口Mining and quarrying, energy and water

\section{口Manufacturing}

\section{口Construction}

-Trade, transport, storage, hotels and restaurants, communication

\section{口Financial intermediation, real estate}

Public services, education and health, miscellaneous services

Figure 1.2: Value added per economic sector in the district of Aachen and in Germany (Source: IT.NRW, 2020)

Both the district of Aachen and the neighbouring district of Düren, which has an area of $941 \mathrm{~km}^{2}$ and has approximately 264,000 inhabitants in 2018 (IT.NRW, 2020), form the structural Aachen region ${ }^{5}$, which is characterised by strong economic linkages (Figure 1.3). A focus on this structural region is important, especially to provide a comprehensive picture of the regional energy transition.

5 The area of the district of Düren, as well as the district of Heinsberg, and Euskirchen, together with the district of Aachen and the city of Aachen, form part of the historical governmental district of Aachen as well and are also referred to as the Aachen region (Region Aachen Zweckverband, s.a.). This is a rationale for labelling the districts of Aachen and Düren as the Aachen region. 


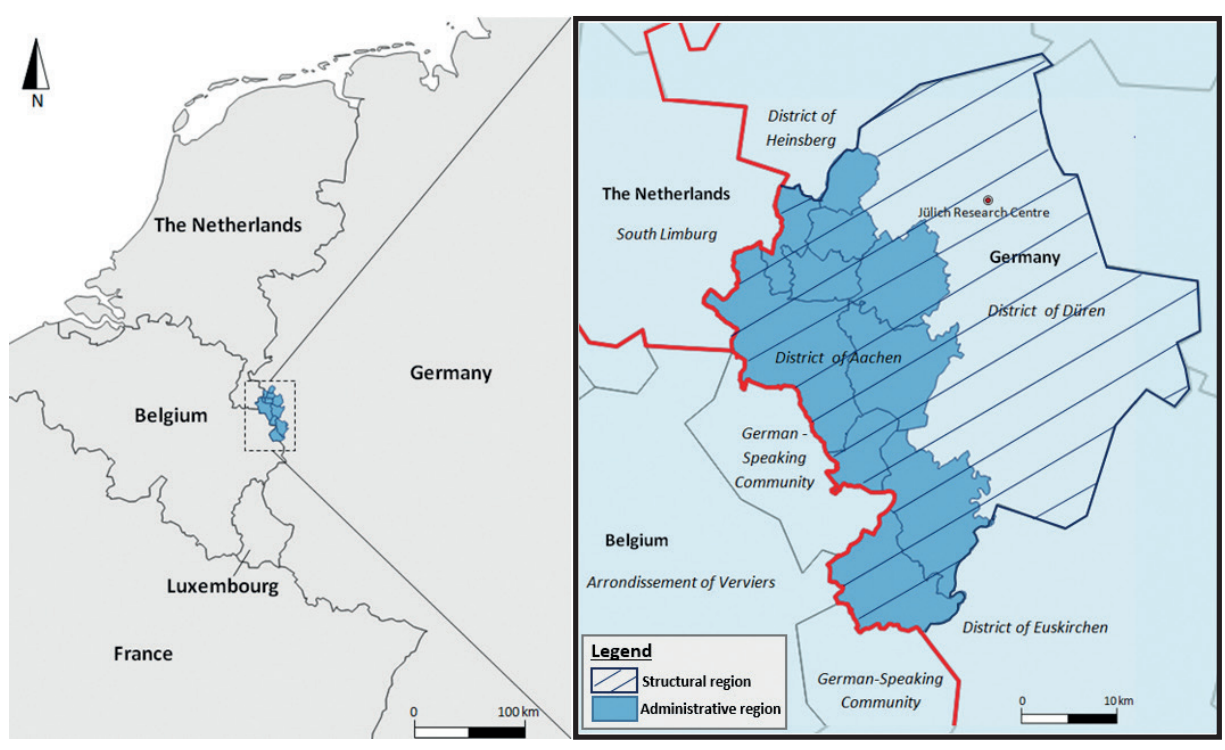

Figure 1.3: Situation of the district of Aachen (German: Städteregion Aachen) in Europe (left) and neighbouring territorial units (right) on NUTS $3^{6}$ level (Source: Jenniches and Worrell, 2019, modified; map data sources: Eurostat, s.a.a)

Both districts are part of the Rhenish lignite mining area (Rheinisches Braunkohlervier), where mining and energy generation are historically rooted in the regional economy. In addition, we find a strong specialisation in research and development in the Aachen region, which covers a total area of $1,648 \mathrm{~km}^{2}$ and has 819,000 inhabitants.

The Aachen mining area is one of the oldest black coal mining regions of continental Europe. The last coal mine was closed in 1997 (Bergbaumuseum Grube Anna e.V., s.a.). Lignite is still mined in the open cast mine Inden, which lies in the district of Aachen and the district of Düren. The mine, which is operated by the utility company RWE Power AG, is supposed to close by 2030 (RWE Power AG, s.a.). The mineral resources are converted into electricity and heat in the power plant Weisweiler (located in the eastern part of the district of Aachen), generating 15.3 terawatt-hours (TWh) of electricity per year (mean value of electricity generation from 2012 to 2014) (RWE Power AG, s.a.). In spite of its economic focus on mining and conventional energy generation, the Aachen region has been an early mover in terms of institutional

6 NUTS is a European Union spatial classification and stands for Nomenclature des Unités Territoriales Statistiques (English: Classification of Territorial Units for Statistics). NUTS 1 is the largest scale for regions in a country, whereas NUTS 3 is the smallest scale. 
changes toward renewable energies. Of particular note is that the predecessor of the feed-in tariff for renewable energy plants (the Aachen model) was developed in the region. Moreover, various research and development ( $R \& D$ ) organisations that are actively involved in the renewable energy sector, such as RWTH Aachen University and the Jülich Research Centre, are located this region. ${ }^{7}$ Therefore, the region allows for a comprehensive study of the energy transition on a small scale and has, therefore, been chosen as a case study for the energy transition, with a focus on the power sector. The results of the assessments of the case study region are compared to various other regions to illustrate methodological specifics and the transferability of the evaluations to other regions.

\subsection{Objectives of the thesis and research questions}

The overall goal that was formulated is approached through sub objectives and individual research questions, which are presented below.

One of the main challenges of renewable energy developments is the job losses in conventional energy industries (Flauger, 2015). Job losses may present a serious threat in undiversified industries that are heavily specialised on fossil energy generation such as, for example, the lignite industry, where renewable energies pose a challenge for traditional business models (Tenta, 2015; DEBRIV, s.a.). However, the renewable energy sector is a driver for more sustainable economic growth and can create opportunities for enterprises as well as for regions (del Río and Burguillo, 2009). These opportunities should be evaluated comprehensively along with the potential challenges so that stakeholders are able to make sound decisions from a macroeconomic perspective regarding whether it is beneficial to develop renewable energies in a region.

Multiple instruments and methods are available to quantify the impacts of renewable energies on the regional economy, such as employment ratios, supply chain analyses, regional input-output tables (RIOT), or computable general equilibrium (CGE) models. Because of the availability of diverse methods, the first task is to select the most suitable method for an individual study on a regional level. Selecting a particular method depends on which impacts are to be investigated, such as the regional gross domestic product, the regional value added, or employment effects. Other determining factors are the assessment time (i.e. present or future impacts) and the size of the region. However, a critical assessment of the methods is rarely carried out in

7 A more comprehensive analysis of the region's characteristics is given in Chapters 3, 4, and 5. 
existing studies (an exception is Llera-Sastresa et al., 2010, who compare analytical to economic models), and no comprehensive overview exists regarding the advantages and disadvantages of instruments that assess the impact of renewable energy on a regional scale. This makes it challenging for researchers and practitioners in the field to identify the most efficient method.

To close this literature gap, the first objective of the thesis is, therefore, to investigate the most efficient method for assessing the regional economic effects of using renewable energies for power generation. Consequently, we can deduce the following research question:

RQ 1: What is the most suitable method for evaluating regional economic effects of renewable energies?

In addition to the regional economic impacts generated by the renewable energy industry ${ }^{8}$, additional impacts of renewable energy developments are generated from an overall macroeconomic perspective. For example, avoiding air pollution leads to enhanced public health, and avoided GHG emissions have a positive impact on ecosystems and the environment by mitigating climate change effects such as rising sea levels and desertification (NASA, 2020). A challenge exists with respect to the visibility of environmental effects such as GHG emissions or pollution, where the amounts of avoided pollutants or GHGs may when presented as mere numbers, not be tangible and usable units for decision makers, who are generally not familiar with these dimensions. By monetising the environmental effects in terms of the avoided external costs of GHG emission and air pollution, the impacts can be illustrated more visibly and therefore offer a more appropriate hands-on base for decision-making (Krewitt, 2002; Fouquet, 2011).

Existing studies in the field focus either on the purely economic impacts (e.g. Bröcker et al., 2014; Moreno and Lopez, 2008; Slattery et al., 2011) or the environmental ones for regional renewable energy developments (e.g. Munksgaard and Larsen, 1998; Cullen, 2013; Novan, 2015). However, in doing this they fail to assess the benefits of renewable energies in a comprehensive way. Nevertheless, illustrating the whole range of benefits provides a sound decision base for decision makers regarding the overall impacts of regional renewable energy developments. Another objective of the thesis, then, is to provide a comprehensive, integrated assessment of the regional economic and 
environmental economic effects of renewable energy sources to close this gap in the literature. As the methods that have been applied as well as the data required are quite comprehensive and results vary broadly between the various technologies, the following question will be posed for the technologies that currently offer the largest renewable electricity generation potential in Germany: PV and wind power (Henning and Palzer, 2012):

RQ 2: What regional economic and environmental effects are generated because of the development of solar PV and wind power?

The development of renewable energies may be controversial and the subject of considerable debate. Particularly in some regions that rely on the fossil fuel industry, energy transformation may be perceived as a threat to the regional economy (Knauß, 2018). For this reason, a comparison of the impacts of renewable energies and fossil fuels should be carried out to provide a basis for stakeholders when they are deciding about relying further on fossil fuels or developing renewable energies instead. Some studies have already been done on the benefits of renewable energies in relation to conventional energy carriers. However, these studies focus either on environmental economics, such as Munksgaard and Larsen (1998), Roth and Ambs (2004), and Novan (2015), or on purely economic effects, such as Sevilgen et al. (2005) and Tourkilas et al. (2009), and mainly considers the national level. Studies that comprehensively compare the effects of investing in renewable energies or fossil fuels from an economic and environmental view on a regional scale are missing in the literature. To close this literature gap, the potential benefits and disadvantages of renewable energies should be comprehensively investigated in comparison to those of conventional energy carriers, leading to the following research question:

RQ 3: What are the regional economic and environmental benefits of renewable energies in relation to conventional energy carriers?

In spite of the potential economic and environmental benefits of renewable energies, we find that the current transformation rate of the energy system is not sufficient (UNEP, 2019). As a consequence, we need to identify drivers of and barriers to the energy transition that go beyond a mere economic and environmental perspective. This can be achieved by analysing the interplay between renewable energies and fossil fuels from a socio-technical system perspective. By evaluating actors and formal and informal institutions of renewable and conventional energies, the concluding part of this thesis presents a systemic and comprehensive analysis of a regional energy transition that makes it possible to identify barriers and supporting factors. Such 
analyses have so far either been presented on a national level (e.g. Geels et al., 2016; Verbong and Geels, 2007) or insufficiently take the regional characteristics of both the conventional energy generation system and renewable energies into account (Smith et al., 2010; Truffer and Coenen, 2012). The thesis closes this gap by putting the interactions between fossil fuels and renewable energies in regions in the centre of the analysis. Against this backdrop, the final objective of the thesis is to identify additional factors that support the energy transition, in addition to the economic and environmental benefits, and to develop policy measures that are transferable to other regions as well, taking into account their individual characteristics and situations. This leads to the following research question:

RQ 4: How can a regional energy transition be supported?

These research questions contribute to the overall goal of this thesis. Research Question 1 concerns the methods for assessing the regional economic impacts of renewable energies based on individual characteristics of the study. Research Question 2 addresses the assessment of the regional economic and environmental impacts of PV and wind power. To answer Research Question 3, a comparison is carried out to illustrate the regional economic and environmental impacts of renewable energies in relation to fossil energy carriers. This is to provide an evaluation of the impacts of regional energy transitions and a ground for regional stakeholders to decide on a transformation of the energy system. Based on these outcomes, factors that support regional energy transitions are evaluated to respond to Research Question 4, to steer regional energy transformation processes in a more efficient way.

\subsection{Structure and outline of the thesis}

The main body of the thesis (Chapters 2-5) is divided into three parts. Part I of the thesis (Chapter 2) deals with regional economic impact assessments of renewable energies and investigates the most suitable methods for evaluating the regional economic effects of renewable energies (Research Question 1). This chapter evaluates the criteria for determining what must to be considered to undertake a regional impact assessment. The essential criteria include the spatial scale of the assessment (i.e. administrative division and size of the region), economic impact indicators (i.e. employment or further economic indicators such as value added), and the assessment time (i.e. historic, current or future impacts). Based on these criteria, a guideline is designed for selecting an appropriate assessment methodology for regional economic impacts. Additional impacts are then discussed, including those that are not purely economic such as the external costs of avoided fossil fuel use, building regional 
capacities to innovate, or the export chances of renewable energy technologies. These should ideally be considered in impact assessments as well.

Part II moves from theory to practice by investigating the regional economic and environmental impacts generated by the development of PV and wind power (Research Question 2). The district of Aachen (a NUTS 3 region) is chosen as a suitable spatial entity. Based on the criteria identified in Part I, an impact assessment for PV technology is carried out by applying a supply chain analysis that covers the whole lifecycle of the technology (Chapter 3). The PV technology presents a special case because of a changing market structure. Business models for operators that relied on feeding generated electricity into the grid while benefitting from feed-in tariffs changed toward self-consumption of generated electricity. This has mainly occurred in Germany since 2012. The first contribution of this chapter is the assessment of both the economic impacts in terms of employment effects and the regional value added, which is defined as regional profits of enterprises, earnings of employees of regional enterprises, and regionally allocated taxes, together with an analysis of the further environmental benefits of avoided GHG and air pollution. These environmental effects are monetised to become a visible and tangible dimension for decision makers in preparing the ground for a sound decision on the further development of RES. This chapter then provides a comparative overview of other economic impact studies in the field and critically discusses results and methodologies. Chapter 4 presents an impact assessment of wind power, the most important technology with regard to renewable energy sources for electricity generation in the district of Aachen. With respect to $\mathrm{PV}$, this study illustrates ways for assessing the regional economic value added with a supply chain analysis. Furthermore, additional benefits (i.e. avoided GHGs and air pollution) are taken into account and monetised. The results are compared to existing studies in the field in terms of both individual results and methodological differences. In addition, the regional economic and environmental effects generated by the development of wind power and PV in comparison to those of conventional energy carriers are investigated to provide a complete picture for decision makers (Research Question 3). From a scientific perspective, Chapters 3 and 4 contribute to the development and testing of a comprehensive integrated assessment of renewable energies in terms of regional economic and environmental effects and provide a better understanding of the various impacts of developing various fossil- and renewable energy generation technologies on a regional level.

Part III contains a comprehensive overview of regional energy transformations (Chapter 5). It investigates factors that support and hamper a transition and provides further details regarding how renewable energies evolve in a potentially hostile 
socio-technical environment such a lignite mining areas with a strong socio-cultural embeddedness regarding fossil fuels, as exemplified by the structural Aachen region. Using a multi-level perspective (MLP), actors, institutions, and technologies related to renewable and conventional energies, as well as overarching developments such as the Fukushima disaster in 2011 that initiated the German nuclear phase-out are analysed to find patterns that explain the regional energy transition. Environmental and economic indicators, and social, political, and institutional characteristics are also discussed, to consider all the dimensions of a sustainable development (Evans, et al., 2009). This accounts for a multidimensional and multidisciplinary view on the energy transition, which is rarely found in the existing literature. The thesis then presents technology-specific strategies and a tailored overall strategy for the energy transition, based on the institutional characteristics in the region. This multidisciplinary and multidimensional approach may act as a blueprint for analysing and fostering energy transformations in other regions as well (Research Question 4).

Figure 1.4 illustrates the parts and chapters of the thesis and their interconnections in a simplified outline, by referring to the number of the part, the main issues explored and the economic, technical, environmental, economic, social, and formal and informal institutional dimensions covered.

The thesis concludes with a summary of the results, policy implications, and ecommendations for further research (Chapter 6).

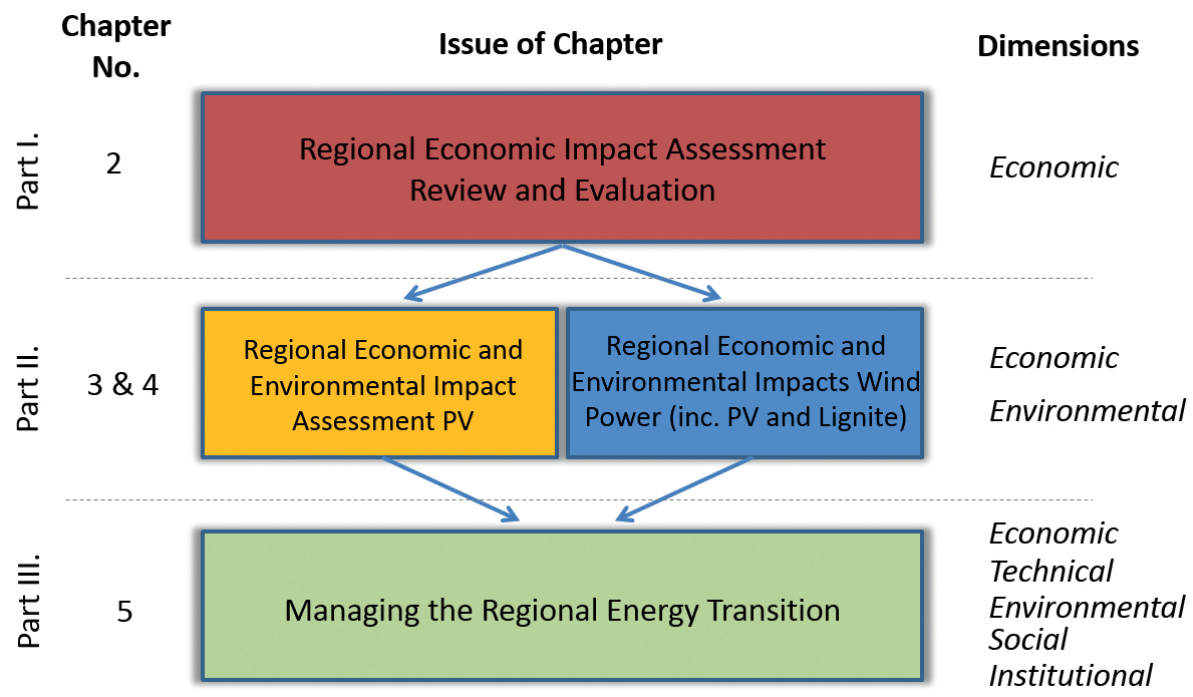

Figure 1.4: Structure of the thesis 



\section{Assessing the Regional Economic Impacts of Renewable Energy Sources - A Literature Review}

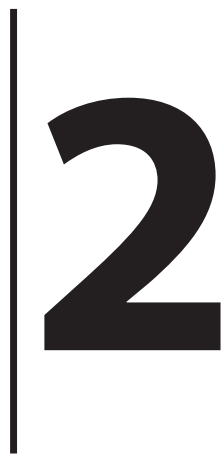

This chapter is based on the publication: Jenniches S. Assessing the regional economic impacts of renewable energy sources-A literature review.

Renewable and Sustainable Energy Reviews 2018;93:35-51.

https://doi.org/10.1016/j.rser.2018.05.008. 


\section{Abstract}

The transition of the global energy system is one of the main trends that offers opportunities as well as challenges for the economy. Most literature evaluates the impact of that transition at a national level. That view is broadened towards a regional scale. Due to the lower energy density of many renewable energy sources, renewable energy generation will be more decentralised, leading to potentially significant changes in the regional economy when transitioning to a renewable energy system. In this paper the current literature and methods of assessing regional economic impacts of a transition to renewable energy generation is reviewed. The findings suggest an overall need to clearly define the topics, such as technologies, that are assessed and the evaluated time period. A guideline for a regional impact assessment is provided, focusing on the suitability of applied impact assessment methods (employment ratios, supply chain analyses, input-output models, and computable general equilibrium models). 


\subsection{Introduction}

Among researchers in the field of climate, it is widely accepted that the emission of greenhouse gases is changing the world's climate. This negatively impacts the ecosystem (NASA, 2017). As the highest proportion (25\%) of greenhouse gases is emitted by heat and electricity generation (IPCC, 2014), increasing the development of renewable energy sources (RES) development is an important strategy for reducing greenhouse gas emissions and thus combatting climate change.

Therefore, facilitating and accelerating the development of renewable energy technologies for the generation of heat and electricity is a key point in the global debate about the energy transition, as it requires a structural change to the energy system (United Nations, 2016). This structural change creates new economic impulses (e.g. growth of the wind power industry) but also decreases investment in traditional energy industries (e.g. the lignite industry) (Gerbaulet et al., 2012).

On a spatial scale, the conventional energy generation system which is based on large centralised energy generation units is shifting to a smaller scale, decentralised, spatially dispersed system of energy generation (BMVI, 2015).

The various renewable energy technologies (e.g. wind power, solar photovoltaic (PV) or geothermal energy) require different location factors and not every location may be equally appropriate. Therefore, a change in the spatial arrangement of energy generation systems is taking place. Traditional locations for energy generation (e.g. lignite or hard coal mining areas) may lose their substantial significance in favour of renewable energy generation locations, if the former do not possess suitable local conditions for the generation of renewable energy $(\mathrm{RE})^{9}$, which leads to economic losses. In contrast, locations where energy generation by non-renewable energy carriers does not take place may be integrated in the system and benefit economically due to the possibility of providing energy generation potentials for renewable energy systems, which is especially important for economically less favoured regions such as rimlands. An example of a region making use of that potential may be the economically less favoured North German state Schleswig-Holstein which has aimed to achieve a share of $300 \%$ of its gross electricity consumption from renewable sources by 2025 (Schleswig-Holsteinischer Landtag, 2015), thus making the region a future electricity exporter. It can be concluded that changes which take place in the spatial arrangements of the energy system are characterised by a transregional crowding

9 Regarding the discussion of changing spatial arrangements concerning energy systems from a historical perspective cf. Brücher (2008). 
out of conventional energy generation plants and a development of renewable energy generation facilities in regions with sufficient potentials for this kind of energy generation.

Although there is a broad body of literature assessing the economic impact of shifting to a renewable energy system on a national scale (e.g. Hillebrand et al., 2006 and Lehr et al., 2012 for Germany, Wei et al., 2010 for the US, or de Arce et al., 2012 for Morocco), there is relatively little attention paid to the economic impact of RES on regions, whereas at this geographic level the changes may be more significant. Focusing on a lower geographic level concerning the effects of RES, developments may be beneficial for various reasons. Firstly, decision-making on the deployment of RES sometimes takes place at a local or regional level instead of the national level, because regions may have decision-making power to hinder, or promote the deployment of RES, as Jacobsson or Bergek (2004) show this in an example of the Dutch wind power industry. Assessing the economic benefits of RES, will help decision makers to understand the impacts of the development of RES in their regions. Besides the benefits for RE industry related businesses that are located in the region, information on the economic potentials may support other regional businesses in order to identify market opportunities or encourage businesses from outside to settle in a region. Therefore, the economic potentials of RES may offer a substantial opportunity for many regions.

Moreover, assessing the regional economic impacts of RES may be particularly important in regions where RES developments are observed critically, since illustrating the regional benefits leads to an increasing acceptance of RES by the population (BMVBS, 2013) which makes it easier for decision makers and especially for elected ones to communicate positive aspects and decide in favour of RES developments.

Furthermore, because of spatially diverse natural conditions, potential economic impacts should be evaluated rather on a regional than on a national scale (unless the potentials in a country are evenly distributed). For example, the average yearly full-load operating hours of wind turbines are approximately 1/3 higher in Schleswig-Holstein (North Germany), than in Bavaria (South Germany) (BWE, 2012). Additionally, in some countries RES industries are found spatially concentrated. For example, in Germany, approximately $23 \%$ of the employees of the wind power industry were employed in the North German federal state Lower Saxony in 2013 (Ulrich and Lehr, 2014).

As conditions vary, it is important for regional decision makers to evaluate which technologies include the best economic potentials in terms of natural conditions available and where regional economic potentials may efficiently be exploited in order 
to benefit from the opportunities of the energy transition. Relying on national impact assessments does not adequately take into account the specific local and regional natural conditions and economic potentials in a country and provides no solid decision support for regional decision makers when defining a regional RES strategy.

In the case of the German wind power industry it has been found that regions take advantage of the potentials because there is a more progressive deployment of wind power in the North of Germany (which has a more favourable wind regime), than in the South (BDB, 2015 in Leipziger Institut für Energie, 2015). Nevertheless, potentials may still not be fully exploited which calls for comprehensive economic impact assessments on a regional scale. These assessments should be attached to regional energy potential studies or regional energy strategies covering economic and ecological effects of renewable energy developments using an integrated approach.

Conclusively, national economic assessments are useful for defining an overall national RES strategy covering e.g. legal frameworks or financial support of economically promising RE technologies. However, when it comes to regional decisions of RES deployments or a definition of a regional strategy for RES developments which may be location and technology specific, regional assessments are more beneficial than national evaluations and complement them. The overall aim of the paper is to provide a review of existing literature in the field of regional economic impacts of RES and to set up a guideline for impact assessments. One cannot claim to refer to economic development as the most important aspect concerning a sustainable regional development which covers issues of "environmental quality, social equity, and economic welfare" (Shaker and Zubalsky, 2015:1). Evaluating environmental quality or social equity concerning RES deployment are also important issues of the discussion (Evans et al., 2009). However, the aim of the study is not to narrow down a sustainable regional development only to economic aspects, but to focus on economic development by RES as an important part of the debate.

The paper especially addresses researchers and analysts involved in the field of RES and regional economic impact analyses. Besides presenting existing literature, necessary steps to be taken in assessments are illustrated, as well as a critical review of the advantages and disadvantages of applied methods in the field so as to assist in choosing a suitable method for individual regional impact assessments. Furthermore, practitioners and regional decision makers are informed about the possibilities and potential benefits of economic impact analyses which may encourage them to integrate such analyses in RES strategies, legitimating RES developments in their regions. 
After referring to the procedure of literature selection and analysis (Section 2.2), evaluated regions, assessed technologies and time periods of publications are illustrated and discussed (Section 2.3). Four general methodological impact assessment approaches were identified i.e. employment ratios, supply chain analyses, input-output modelling, and computable general equilibrium models. A review of these approaches is provided in Section 2.4, including a detailed analysis of methodological strengths and weaknesses. The conclusions discuss the findings and provide guidelines for a comprehensive impact assessment for RES transitions (Section 2.5).

\subsection{Process of literature selection}

Although it cannot be claimed that every existing study in this field has been evaluated, a large body of literature has been analysed in order to capture the current debate and developments on evaluating and assessing the regional impacts of RES. Assessment methods which have been applied in the different papers are discussed concerning their strengths and weaknesses and applicability in specific contexts, which may help researchers to identify suitable methods regarding regional impact assessments.

To find relevant publications, a literature search was conducted, using the keywords 'economic impacts', 'economy', and 'renewable energy' in English and German. The most used sources were the internet platforms 'Google', 'Google Scholar', 'ScienceDirect', and 'Web of Science'.

After scanning the literature references of appropriate publications to further identify literature, all relevant English and German speaking publications were filtered by including only literature concerning economic impact assessments on a regional scale. German publications were integrated as well, since they included various approaches which were not applied in English papers on a regional scale. In addition, German publications were used to evaluate the approaches to a non-German speaking audience.

The term region may be defined differently given the research context (Faniran, 1980), and refers to an administrative unit on the sub-national scale in this paper. Because of the fact that the characteristics of administrative units in countries (e.g. size, population) may vary on an international scale, European regions have been categorised into the NUTS (Nomenclature des Unités Territoriales Statistiques; English: Classification of Territorial Units for Statistics) system on EU scale. In the nonEuropean examination areas, which consist of regions in the United States the national classifications have been used (Section 2.3.1). 
The 81 publications identified were scaled down to 54 publications (these include 42 publications in English and 12 in German). Excluded publications contained a different version of studies reported in earlier studies. Solely methodological papers were included in Section 2.4 in this paper. Figure 2.1 illustrates the literature research process schematically. Limitations of the approach are that literature which was not found might exist, because it was not registered in the used search engines, nor cited by the reviewed articles. Moreover, literature which has not been published in English or German is not included.

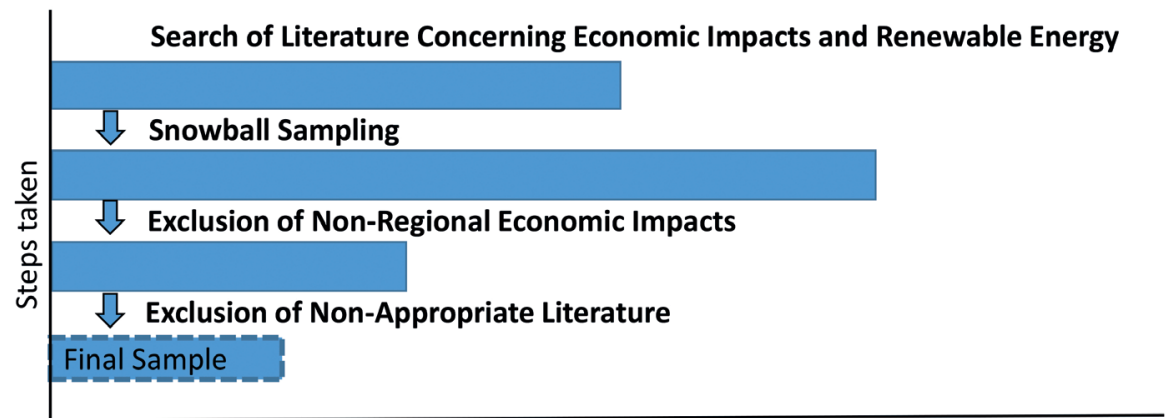

Sample size

Figure 2.1: Schematic illustration of the literature research and scaling down process with steps taken (in bold letters) and approximate sample size

If an English and German version of a publication existed, the English version was evaluated due to a better comprehensibility for non-German speaking readers. Most of the publications (70\%, $n=42$ ) were published from 2005-2015, whereas only one publication dating from before 2000 (1995) was identified and one publication contained no publication date.

Eleven publications were journal articles in peer reviewed journals and 43 publications were grey literature such as project reports. This demonstrates an apparent lack of attention in the peer reviewed literature, despite a quite broad body of literature in the field. 


\subsection{Evaluated regions, technologies, impacts and time periods}

At the beginning of this section, countries and regions where regional economic impacts have been evaluated are discussed (Section 2.3.1). The next step presents RE technologies that have been analysed in the publications (Section 2.3.2). Additionally, different economic impact measurement indicators that have been investigated in the reviewed literature are defined including an assessment of the quality of individual impacts (Section 2.3.3). The studied time periods of the impact assessment are discussed in Section 2.3.4.

\subsubsection{Regions covered by the reviewed publications}

Most of the publications refer to regional economic impacts in the United States (US) $(n=33)$, followed by Germany $(n=12)$, Spain $(n=5)$, Austria $(n=2)$ and the United Kingdom $(U K)(n=2)$. Concerning the publications about US regions, short fact sheets about the economic benefits of 1,000 megawatts (MW) of wind power in 15 different states were identified. Due to the fact that these short reports were written by the same authors using exactly the same methods (Lantz and Tegen, 2008a-I and Lantz and Tegen, 2009a-c) they have been counted as a single publication (Table 2.1).

Table 2.1: Spatial scale of the analysed territories and language used

\begin{tabular}{|c|c|c|c|c|c|c|c|c|}
\hline & \multirow{2}{*}{ Country } & \multirow{2}{*}{ NUTS 1} & \multirow{2}{*}{ NUTS 2} & \multirow{2}{*}{ NUTS 3} & \multirow{2}{*}{ LAU 2} & \multirow{2}{*}{ Other } & \multicolumn{2}{|c|}{ Language } \\
\hline & & & & & & & English & German \\
\hline \multirow{4}{*}{ 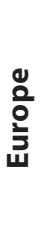 } & Austria $(n=2)$ & & 1 & 1 & & 1 & 2 & \\
\hline & Germany ( $n=12$ ) & $25(16)^{10}$ & 1 & 2 & 11 & 4 & & 12 \\
\hline & Spain $(n=5)$ & & 5 & & & & 5 & \\
\hline & UK $(n=2)$ & 2 & & & & & 2 & \\
\hline \multirow{2}{*}{ ๕ั } & \multirow{2}{*}{ USA $(n=33)$} & \multirow{2}{*}{\multicolumn{2}{|c|}{$\begin{array}{l}\text { State } \\
42(25)\end{array}$}} & \multirow{2}{*}{\multicolumn{2}{|c|}{$\begin{array}{c}\text { County } \\
49\end{array}$}} & Other & \multirow{2}{*}{33} & \\
\hline & & & & & & 2 & & \\
\hline
\end{tabular}

To enable an approximate categorisation of the different regions regarding their spatial scale, the publications which concern European regions are categorised using the NUTS system. The NUTS classification is a European system which enables a broad comparability of administrative units on an international scale. In the classification, a

10 Total number of assessed regions ' 25 ' and different analysed regions in brackets '(16)' 
NUTS 0 region refers to countries and NUTS 1-3 regions refer to regions. The difference between the categories is based on population thresholds and covers administrative divisions, whereas the higher the classification number, the smaller and less populated the region. LAU (Local Administrative Units) refer to municipalities or comparable administrative levels in the EU (Eurostat, s.a.b). However, European NUTS classifications are naturally not existent in the United States. Concerning US states, the US spatial categorisations states and counties are used. In the following table, other regions refer to territories which are not defined by the NUTS classification or which are aggregated regions (e.g. the Mid-Atlantic region in the US which is formed by four states but not clearly defined as an administrative unit). Some regions have been analysed multiple times. Therefore, the number of different evaluated regions in a country is depicted in brackets.

Regarding the publications concerning European regions, the most often assessed administrative units are on NUTS 1 level, whereas specific economic impacts have been assessed for all 16 NUTS 1 regions in Germany. Consequently, a comparability of European regions regarding an impact analysis may be more reasonable at the NUTS 2 level, for which publications from three different countries have been identified. However, when comparing the impacts of RES in different regions, specific regional characteristics should be considered, which are discussed in Section 2.5.

In the US, the most often evaluated territories are at county level, followed by regions on state level. On state level, 25 different states have been assessed including the State of Texas which is the most analysed region in the whole sample (4 publications).

When assessing the impact of RES, it is important to clearly define the country or region where impacts are assessed due to, for example, different characteristics of the regional economy, individual costs for products and services, or labour productivity in various regions (Costello, 1993), which obviously affect the results. Assessing impacts on an aggregated territorial scale without differentiating between individual administrative units bears further disadvantages. First of all economic statistics, which are necessary for a comprehensive analysis are often not available on an aggregated scale. Moreover, policy actions that are based upon impact assessments are in most cases initiated by individual political institutions in the respective administrative units and if benefits for individual administrative units are not illustrated, actions may not take place. Therefore, regions should be clearly defined administrative units.

The NUTS classification is a useful system that enables a cross-state categorisation of European regions, but unfortunately there is no comparability to non-European 
administration systems such as the US. Therefore, to enable a comparison between European and non-European regions, data about the specific characteristics of regions such as the area size, population, etc. should be taken into account.

Nevertheless, in terms of comparability of economic impacts of RES in regions, individual characteristics of regions like the regional economy (Ulrich et al., 2012) or natural conditions (Section 2.1) play a role which makes them unique and in a way incomparable. Therefore, the primary goal of an impact assessment should not be the comparability of regions but rather to develop a scheme to optimally measure regional economic impacts (Section 2.5).

\subsubsection{Technologies covered by the reviewed publications}

It is important to define which RE technologies are assessed, because regional economic impacts differ between various technologies. For example, the impact of a small solar PV plant on the local economy may differ from the impact of a large hydro plant. Moreover, in some regions a technical or economical potential for the applicability of a technology might not exist (e.g. installing solar PV systems in a region with insufficient global radiation or wind plants in regions with unfavourable wind conditions).

A first distinction of RE technologies may be made by the applicability of a technology. In this case, heat, electricity, or fuels can be defined as potential energy types. Some authors do not clearly define the type of energies being assessed. In the analysis the focus lies on heat and electricity only. Only a few regional studies focusing on heat and electricity evaluate the economic impacts of biofuels as well (e.g. Moreno and Lopez, 2008), which is insignificant in the subsequent literature review. Figure 2.2 shows the technologies evaluated and the type of energy such as electricity or heat which is produced by that RE technology. 


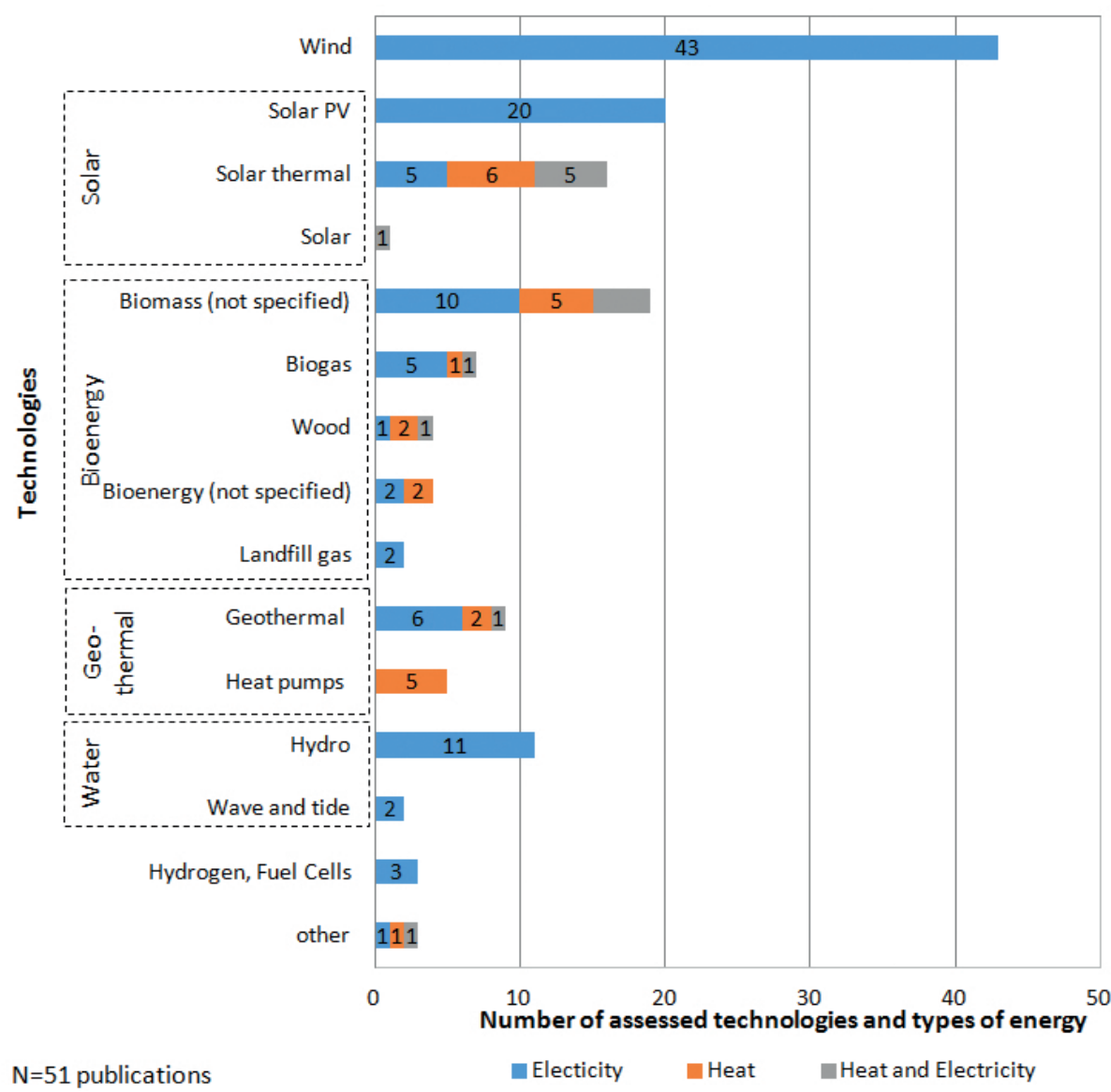

Figure 2.2: Number of assessed technologies and types of energy carrier

In the graph only 51 articles are included, because three articles did not focus on the economic impact of a defined RE technology but on an aggregation of several technologies to a RE system.

Most publications deal with $\mathrm{RE}$ systems regarding electricity generation. In the sample 15 specific technologies, and 111 evaluations of electricity generation technologies were identified. Heat generation was assessed for 8 technologies and 24 times in the sample. Some RE technologies, like biomass, provide the potential to generate electricity as well as heat (e.g. in a combined heat and power (CHP) system). Therefore, some authors did not distinguish between electricity or heat regarding the assessed technologies. Moreover, some authors did not clearly refer to the kind of energy which is produced by the technology. In these cases, it has been assumed, that both heat 
and electricity are generated. Regarding the technologies solar and bioenergy, the authors used the terms as an aggregation of several technologies.

$84 \%(n=43)$ of the publications deal with electricity generation using wind power. The following most important technologies are solar PV $(n=20)$ and biomass $(n=19)$. Therefore, it can be presumed that the outcomes of often analysed RE technologies are more robust than less evaluated technologies. Conclusively, the technology as well as the type of energy (i.e. electricity or heat) should be precisely indicated by the authors in their publications, to permit a clear distinction between technologies assessed and their comparability concerning an impact assessment in different regions. A distinction between technologies is important because of different conditions (solar irradiation, or wind pattern) which may lead to different economic impacts. Moreover, not every technology may be efficiently deployable and usable in every region because of varying geographic conditions (Section 2.5). Distinguishing between technologies in a study may help to understand this factor better.

\subsubsection{Economic impact indicators assessed by the reviewed pub- lications}

Economic impacts can be evaluated by different criteria. One of the most assessed criteria is the number of employees, which is assessed by $93 \%$ of the publications (Table 2.2). There is sometimes no comparability of the indicator employment because some studies take into account part- and full-time jobs (Wei et al., 2010) or even do not provide any information about whether part- or full-time jobs are assessed (e.g. Moreno and Lopez, 2008 or SEED Coalition and Public Citizen's Texas office, 2002). To enable a comparability between different publications and to the number of total jobs in an area, the number of jobs should always be assessed in full-time equivalents (FTE) or person-years. This is the case for $62 \%$ of the publications which assess RE related jobs (93\% of all publications).

The assessment of fiscal effects, which is evaluated by $59 \%$ of the publications are a good example of the financial participation of local or national governments in the local RE industry. This impact is hardly comparable on an international scale because of the various tax systems and different tax rates (Tanzi, 1996). Regarding the example of Germany, Hirschl et al. (2015) for instance, assess every tax occurring in the whole RE industry (e.g. taxes of operating RE by the plant owners as well as taxes of manufacturers of RE equipment and businesses involved in the installation and operation of RE). Another economic impact are the salaries of employees in the RE industry. The significance of that impact is qualitatively higher than the mere number 
of employees which does not include the quality of generated jobs, which may be highly paid white- or low paid blue-collar jobs. Highly paid jobs have potentially larger economic impacts because earnings are ideally spent in the local economy leading to higher regional economic impacts (i.e. induced effects). Induced effects have been calculated by for example Slattery et al. (2011).

Landowner benefits arise from land lease payment from the plant operator to a landowner and occur mostly for the development of wind power plants. However, for some other space-intensive technologies such as large roof-top and ground-based solar PV plants, affordable spaces may also be not owned by the operator. In Germany, platforms already exist like for instance Solardachbörse, where property owners let spaces for roof top systems (Internationales Wirtschaftsforum Regenerative Energien, s.a.), which is a common business model. Therefore, an assessment of land lease payments for other land intensive technologies such as large-scale solar PV plants, or concentrated solar power (CSP) should be assessed in more detail, which has been done by for example BMVBS (2011) or Hirschl et al. (2015).

Moreover, macroeconomic key figures such as gross output, gross value added and gross domestic product (GDP) are evaluated by some publications. Gross output at market prices refers to all revenues of economic agents in a territorial unit. It is calculated by the addition of sales of these agents in a defined period (Colander, 2014). Gross output is investigated by approximately one third (35\%) of the publications. Because of different cost structures and specific characteristics (e.g. the performance) of different RE technologies (e.g. Bröcker et al., 2014), it is important to precisely define economic impacts of specific technologies and not the impacts of RE by aggregating several technologies like for instance Deyette and Clemmer (2005) who illustrate the aggregated employment impacts of solar PV and Wind. Gross output, which is referred to as economic activity in some publications (Costanti 2004, or Lantz, 2009), is mainly assessed for the wind power industry (Table 2.3).

The gross value added (GVA) at market prices can be calculated by subtracting all inputs at purchaser prices from the gross output. Gross value added has been assessed by one fourth (24\%) of published studies and has been evaluated for nearly all RES technologies. Regarding the assessment of GDP, it has only been analysed by two publications for wind, biomass, and a number of aggregated RES technologies. By adding the taxes on products less the subsidies on them, the gross domestic product which includes the final monetary value of goods and services (Callen, 2017) is assessed. The net domestic product (NDP) is the product of the subtraction of consumption of fixed capital. Because of the spatial scale of analysis, only the gross domestic product 
on a regional scale, which may also be referred to as the gross regional product (Isard, $1960)$ is assessed in the publications.

Table 2.2: Number of assessed economic impacts in the reviewed publications

\begin{tabular}{|cll}
\hline $\begin{array}{c}\text { Number of } \\
\text { Evaluations } \\
\text { (N=54) }\end{array}$ & in $\%$ & Impact Categories \\
\hline 50 & 93 & Number of employees (incl. FTE) ${ }^{11}$ \\
\hline 31 & 57 & $\begin{array}{l}\text { Number of employees in full-time equivalents (FTE) } \\
\text { or person-years }\end{array}$ \\
\hline 32 & 59 & Regional taxes \\
\hline 27 & 50 & Salaries of employees \\
\hline 21 & 39 & Landowner benefits \\
\hline 19 & 35 & Gross output \\
\hline 15 & 28 & Other economic impacts \\
\hline 13 & 24 & Gross value added \\
\hline 11 & 20 & Owner of plants revenues \\
\hline 9 & 17 & Proprietor income of firms \\
\hline 4 & 7 & Investment \\
\hline 4 & 7 & Regional GDP \\
\hline 1 & 2 & Turnover \\
\hline
\end{tabular}

Other economic effects such as value of rights of conserved water, (Heavner et al., 2003) or costs avoided for the generation of coal and gas (e.g. Deyette and Clemmer, 2006) are pointed out by approximately one fourth (28\%) of the publications as well.

Benefits of plant operators have been assessed and depicted by only 11 (20\%) of the publications but for almost every technology, whereas 9 publications refer only to $\mathrm{RE}$ in Germany. The generation of renewable energies is linked to locations where the deployment of RE plants is technically and economically feasible because the potential economic benefits for the generation of energy are dependent upon the region's natural resources (e.g. solar irradiation or the wind pattern). Moreover, the development of RES is dependent upon economic profitability of the project and

11 If it not has been pointed out, that full-time equivalent jobs or person-years have been assessed, it has been assumed that only the number of employees has been evaluated. 
therefore is the main factor for the installation of RES. Henceforth, there is a lack of comprehensive evaluation of owner revenues among the publications about regional economic impacts of RES.

Other effects include the proprietor income of renewable energy industry businesses, investments in RE and turnover of involved businesses (Table 2.2).

Table 2.3 shows the indicators assessed for the specific RE technologies, distinguishing electricity and heat. Some technologies enable the generation of electricity and heat, which is referred to as electricity, heat aggregated in the table (Table 2.3).

Table 2.3: Total number of assessed economic impacts per renewable energy technology

\begin{tabular}{|c|c|c|c|c|c|c|c|c|c|c|c|c|c|c|}
\hline 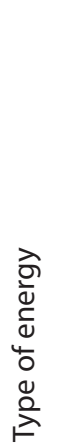 & 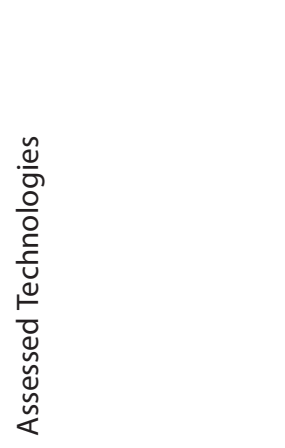 & 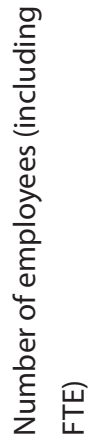 & 崖 & 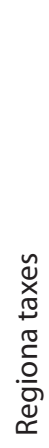 & 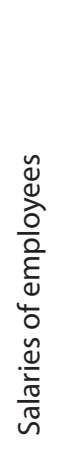 & $\stackrel{⿱}{3}$ & 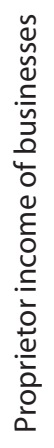 & 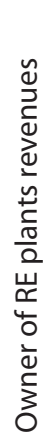 & 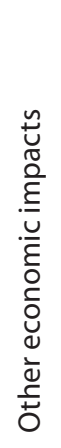 & 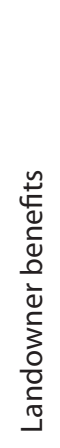 & 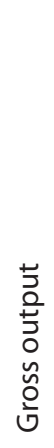 & 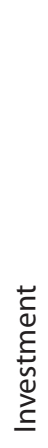 & 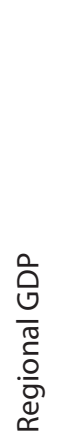 & \\
\hline \multirow{14}{*}{ 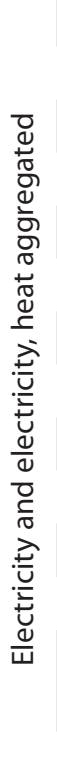 } & Hydro $(n=11)$ & 9 & 6 & 8 & 6 & 6 & 5 & 5 & 2 & 1 & & & & \\
\hline & Wind $(n=43)$ & 39 & 25 & 26 & 22 & 10 & 8 & 9 & 7 & 20 & 15 & 1 & 1 & \\
\hline & Solar $(n=1)$ & 1 & & & & & & & & & & & & \\
\hline & Solar PV (n=20) & 18 & 12 & 9 & 9 & 7 & 6 & 6 & 3 & 2 & 2 & 1 & 1 & \\
\hline & $\operatorname{CSP}(n=10)$ & 9 & 3 & 3 & 2 & 1 & 1 & 1 & 2 & & 2 & 1 & & 1 \\
\hline & Wave and tide $(n=2)$ & 2 & 1 & & 1 & 1 & & & 1 & & 1 & & & \\
\hline & Bioenergy $(n=2)$ & 2 & 1 & 1 & 1 & 1 & 1 & 1 & & & & & & \\
\hline & Biomass $(n=14)$ & 14 & 8 & 4 & 5 & 4 & 4 & 4 & 2 & & 1 & 2 & 1 & 1 \\
\hline & Biogas $(n=6)$ & 5 & 4 & 5 & 5 & 5 & 4 & 4 & & & & 1 & & 1 \\
\hline & Wood $(n=2)$ & 2 & 2 & 1 & 2 & 1 & 1 & 1 & & & 1 & & & \\
\hline & Landfill gas $(n=2)$ & 2 & & 1 & 1 & & & & 1 & & 1 & & & \\
\hline & Geothermal $(n=7)$ & 7 & 5 & 3 & 2 & 2 & 2 & 2 & 2 & & & 1 & & \\
\hline & $\begin{array}{l}\text { Hydrogen, Fuel } \\
\text { Cells }(n=3)\end{array}$ & 3 & 2 & & & & & & 2 & & & & & \\
\hline & Other $(n=2)$ & 2 & 2 & 2 & 2 & 2 & 2 & 1 & & & & & & \\
\hline
\end{tabular}


Table 2.3: Total number of assessed economic impacts per renewable energy technology (continued)

\begin{tabular}{|c|c|c|c|c|c|c|c|c|c|c|c|c|c|c|}
\hline 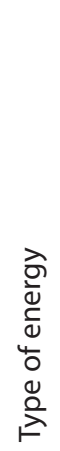 & 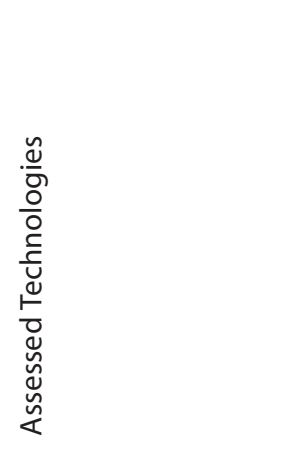 & 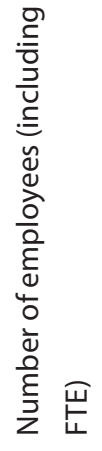 & $\underset{\leftarrow}{\rightleftarrows}$ & 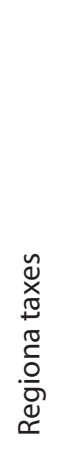 & 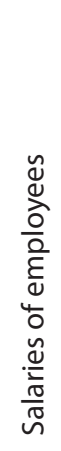 & $\underset{\mathrm{J}}{\mathrm{J}}$ & 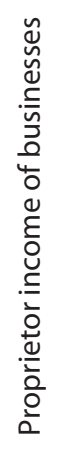 & 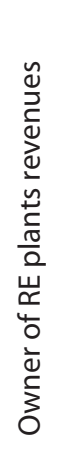 & 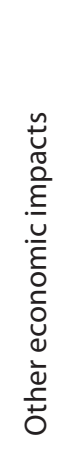 & 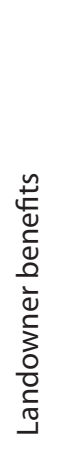 & 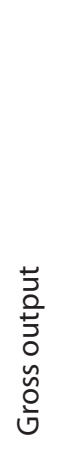 & 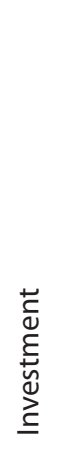 & 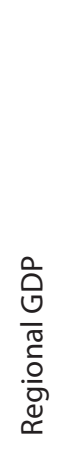 & 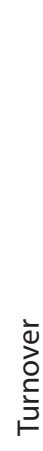 \\
\hline \multirow{10}{*}{ 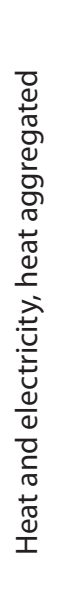 } & Solar $(n=1)$ & 2 & & & & & & & & & & & & \\
\hline & Solar thermal $(n=11)$ & 11 & 6 & 5 & 5 & 5 & 5 & 4 & 2 & & & 1 & & 1 \\
\hline & Bioenergy $(n=2)$ & 2 & 1 & 1 & 1 & 1 & 1 & 1 & & & & & & \\
\hline & Biogas $(n=2)$ & 2 & & 1 & 1 & 1 & 1 & & & & & & & \\
\hline & Wood $(n=3)$ & 2 & 2 & 2 & 2 & 2 & 1 & 1 & 1 & & 1 & & & \\
\hline & Biomass $(n=8)$ & 8 & 5 & 4 & 3 & 4 & 3 & 3 & 2 & & & 1 & & 1 \\
\hline & Heat pumps $(n=5)$ & 4 & 4 & 5 & 5 & 5 & 5 & 4 & & & & & & \\
\hline & $\begin{array}{l}\text { Deep Geothermal } \\
(\mathrm{n}=3)\end{array}$ & 3 & 3 & 2 & 2 & 2 & 2 & 2 & & 1 & & & & \\
\hline & $\begin{array}{l}\text { RES aggregated } \\
(n=3)\end{array}$ & 3 & 1 & 3 & 2 & 1 & 2 & 1 & 3 & 1 & & 2 & 1 & \\
\hline & Other $(n=2)$ & & & 1 & & & & & 1 & & & & & \\
\hline
\end{tabular}

Economic impacts may also be classified as primary or secondary effects. Primary effects refer to direct and indirect economic effects (Breitschopf et al., 2011). Direct impacts refer to purchases of one industry from other industries to satisfy the demand for new RE plants, for example. In order to enable these transactions, these other industries have to purchase goods or services from suppliers which also purchase goods from their suppliers. These effects are defined as indirect effects (Miernyk, 1965). An increase of production by the generated demand leads to additional income of employees and business proprietors of directly and indirectly affected industries. The part of income which is spent by these subjects for example for consumption goods leads to additional secondary effects which are described as cumulative or induced effects. 
Direct and indirect effects are assessed and presented by 21 papers. However, the definition and differentiation between direct and indirect effects vary among the publications. Whereas, for example, the Job and Economic Development Impact model (JEDI) that is used by Lantz (2009), Slattery et al. (2011) and others (Table 2.7) defines all on-site effects of installation, construction, and manufacturing of plant modules as direct effects (Goldberg et al., 2004), BMVBS (2011) defines benefits generated by the generation of electricity by RES as direct effects and all other effects, such as installation and maintenance of RE as indirect effects. Therefore, it is not possible to compare direct and indirect effects among the papers if they do not use the same definitions or methodology. Induced effects have been illustrated by 14 publications. However, total impacts are the same although the categorisation of direct and indirect effect varies. Therefore, in order to enable a comparison of impacts, publications should explicitly describe the impacts concerning their stage in the product lifecycle before categorising them into direct and indirect effects according to their individual definitions.

With respect to the economic impact of different stages in the product lifecycle of different technologies, it is important to stress which stages are assessed in the analysis of economic impacts. Although their specific characteristics may vary between technologies, the lifecycle of RE systems can be divided into five stages which are; research and design, development and manufacture, construction and installation, operation and maintenance (O\&M) or service, updating and/or dismantling (LleraSastresa et al., 2010). Most authors use only an aggregated version of the lifecycle by dividing it into two stages which are 1) manufacturing, construction, installation, and 2) operation, maintenance.

Authors often use the term construction for the stages manufacturing, construction, and installation (e.g. Reategui and Tegen, 2008; Stoddard et al., 2006) to describe the different stages. In order to refer to the ambiguous meaning of the term construction, which may concern the construction activities during the installation of a RE plant only, it should be pointed out clearly which stages are included in the analysis and a clear distinction between manufacturing, construction and installation and operation and maintenance should be made. Authors that take into account installation separately without aggregating the installation and the manufacturing lifecycle stage are for example Algoso and Rusch (2004) or Hirschl et al. (2011). A separation is important in order to estimate the economic impact and compare it to other regions because while a region may not have potential manufacturing resources, local businesses may nevertheless participate economically in the installation phase. 
Most authors do not specify which industries may benefit from economic impacts. This may be an important piece of information for businesses or local economic development organisations. Some authors refer to specific sectors such as finance, insurance and real estate or construction (Weisbrod et al., 1995; Coon et al., 2012) that allows a more specific view on affected industries. However, the RE industry is a cross sectoral industry that is difficult to define because it is usually not statistically classified as an industry (Section 2.4). Therefore, it is challenging to identify which businesses in the sector finance, insurance and real estate may be involved in RE related activities.

Regarding other economic activities affecting local impacts of RE such as research and design, only one publication (Hirschl et al., 2015) points out their local economic impact. Other authors also include this in their studies, but aggregate it with other activities (e.g. Bezdek, 2007; Faulin et al., 2006).

Most of the publications refer only to economic impacts generated by regional demand, for example effects, which are generated by the installation of RE plants within the region studied. Exports outside the studied region by manufacturers or other enterprises, such as RE service companies are often not included in the analyses (e.g. ZSW, 2012; Coon et al., 2012). However, a comprehensive analysis of local economic impacts generated by the RE industry include regional demand as well as exports. Whereas some regions may have a significant natural potential in terms of energy generation, other regions may have a considerable potential of manufacturing enterprises which produce RE components. Publications which include impacts that are generated by non-domestic regional demand are for example Heavner and Del Chario (2003) and Ulrich et al. (2012).

Another difference in impact assessment concerns the evaluation of gross or net impacts. Whereas gross impacts concern only the positive impacts generated by RES deployment in the RE related sectors, net impact studies take into account a comprehensive economic analysis of effects. The aim of net impact studies is to provide a view of overall effects which are generated by investment in RES on the one hand and on the other hand disinvestment in for example fossil energy sources (Breitschopf et al., 2011). In the sample, a comprehensive net impact study has been assessed only by Weisbrod et al. (1995). All other publications are gross impact studies of RE deployment. However, some publications (Algoso and Rusch, 2004; Stoddard et al., 2006) take economic impacts of technologies into account which are based on fossil fuels to enable a comparison of potential effects, although they do not carry out a comprehensive net impact analysis. Moreover, studies which are based on computable equilibrium models (Section 2.4.4) take regional competition for resources (e.g. labour 
(Allan and Gilmartin, 2015) or land rent (Trink et al., 2010)) into account, which leads to negative impacts as well. Concerning net impact studies, positive and negative effects should be precisely pointed out to enable a comparison with other (e.g. gross impact) studies.

\subsubsection{Time periods analysed in the reviewed publications}

The installation costs for wind power plants in the United States, for instance, decreased by $20-40 \%$ between late 2008 and 2015 (DOE, s.a.). Therefore, due to transparency and comparability reasons, the time period of economic impacts should be specified so that publications which include different time periods are comparable. Especially in a dynamic market such as the RE industry, costs and therefore impacts are highly volatile over time for specific technologies (Schröder et al., 2013; Fraunhofer ISE, 2015). However, 12 publications do not indicate what periods are assessed in their study and 7 publications only deal with the economic impacts of a single year. Figure 2.3 depicts the assessed time periods of the publications. Whereas 3 of them deal with historical economic impacts which occurred before the time the paper was written, most of the 35 papers describe future economic impacts $(n=32)$. Although an ex-post analysis may be valuable in terms of a precise evaluation of the RE industry because of available and reliable data, the particular strength of an analysis of future impacts lies in the assessment of potential chances for the regional economy. By estimating future RE deployment and therefore economic opportunities, the local economy may successfully adapt knowledge in the context of RE in terms of becoming a "learning region" (Florida, 1995:527) to satisfy future demand.

Most of the publications (23\%) deal with impacts that occur in a period within 21 different years, which is the assumed average operation period for most technologies (20 years plus 1 year if the operation starts in the middle of a year) (Madlener and Koller, 2007; Bröcker et al., 2014). 19 publications assess up to 20 years of RE deployment (10 up to ten years), while only 8 publications deal with periods longer than 21 years.

The longest period is regarded in Gilmartin and Allan (2015) since they take into account the impacts in a period of 100 years. Most of the publications refer to either one or two technologies or many technologies (six or more). 


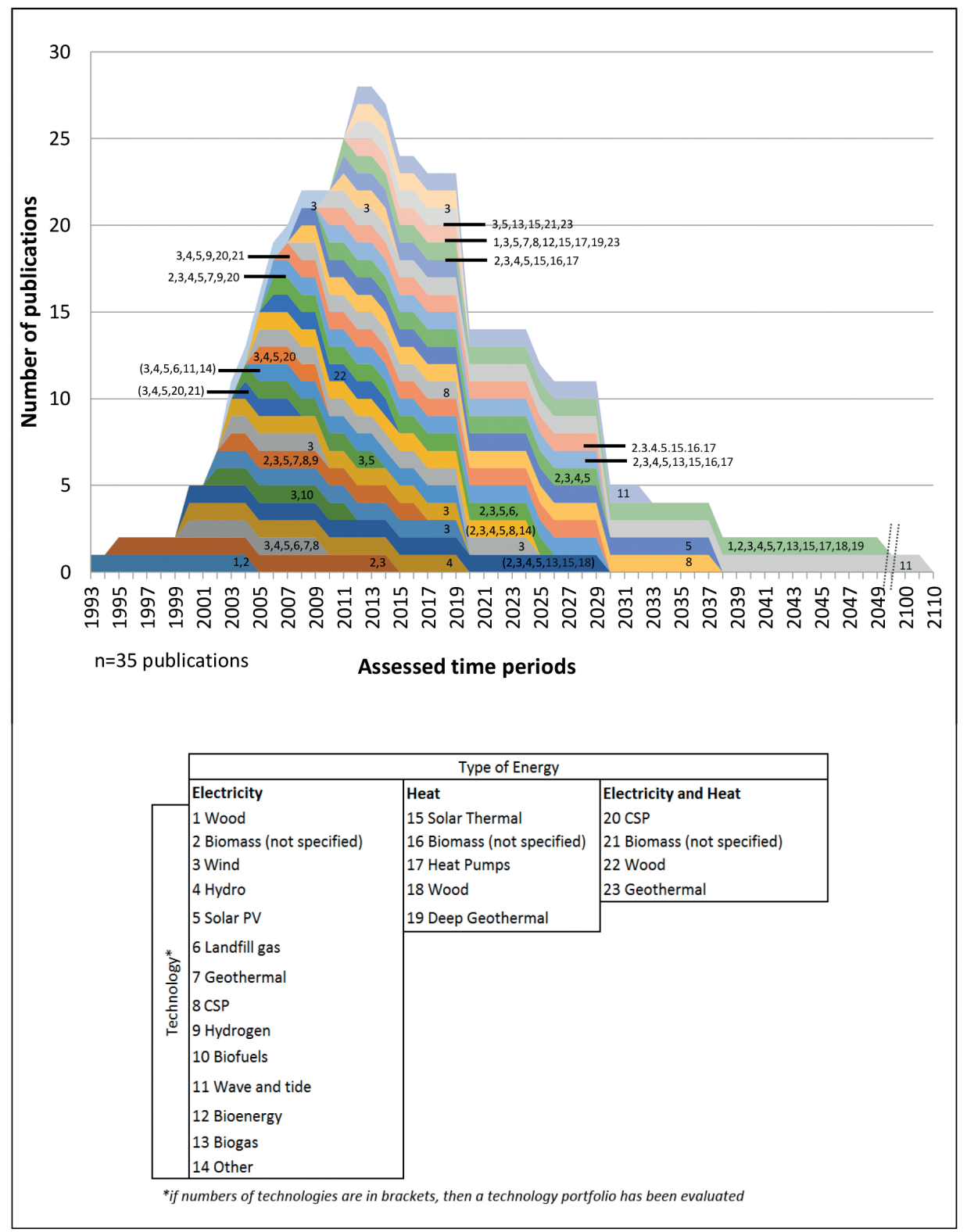

Figure 2.3: Analysed time periods and technologies of the publications

Some publications like, e.g. Loomis and Hinman (2010), Finus et al. (2013) or Slattery et al. (2011) deal with specific RES capacities that are installed at the beginning of the investigated time period and do not consider further RE development in the region during the evaluated period. Other authors like Lantz (2009) or Bröcker 
et al. (2014) take into account deployment during the whole period as well. When assessing deployment which occurs during the whole time, cost reductions of specific technologies because of learning effects, economies of scale (because of the market expansion of a technology) (Isoard and Soria, 2001) should also be taken into account. Even when assessing an allegedly short time period, costs may develop rapidly, as can be shown by the example that the average prices for solar PV systems in Germany decreased by $69 \%$ between the second quarter 2006 and the first quarter 2013 (EuPD Research, 2013). Whereas most of the authors take cost reductions into account (like for example Fanning et al., 2014 or Deyette and Clemmer, 2005), some authors (like e.g. Heavner et al., 2003 or Madsen et al., 2002) point out that they do not consider them in their analysis. Other authors provide no details about cost reductions (Section 2.4.1).

Some publications (e.g. GAO, 2004, or Algoso and Rusch, 2004) take existing scenarios into account such as $20 \%$ of electricity needs in the United States is to be generated by wind power by 2030 (DOE, 2008) which is referred to by Lantz (2009). Other authors deal with a stable amount of RE deployment like an installed capacity of $10 \mathrm{MW}$ of $\mathrm{RE}$ in the region observed (Kildegaard and Myers-Kuykindall, 2006 or Torgerson et al., 2006).

In conclusion, time periods which are analysed should be specified and cost developments over the period should be taken into account when assessing RE development over time. Comparable periods for operation and construction should ideally be assumed, e.g. 20 years for wind or solar PV ${ }^{12}$ to enable a comparison of different studies. Moreover, future RE deployment should follow national or regional development scenarios or targets to provide a realistic perspective on future impacts.

12 The lifetime of individual plants may differ from 20 years of operation and last longer (Fachagentur Windenergie an Land, 2016 for wind power; Wirth, 2014 for solar PV). 


\subsection{Evaluation of methods}

The approaches mainly applied in the reviewed literature sample are analytical methods like employment ratios (Section 2.4.1) and supply chain analyses (Section 2.4.2) as well as methods based on economic models such as input-output models (Section 2.4.3) and computable general equilibrium models (Section 2.4.4). In the following a description of the strengths and weaknesses of the approaches is evaluated, preparing the ground for the discussion in Section 2.5 where the most suitable methods depending on the size of the region, the time of assessment, and the economic indicators are proposed.

\subsubsection{Employment ratios}

Employment ratios or employment factors are used to assess the employment which is generated regarding the total installed capacity or prospective capacity of a specific technology. The sum of jobs is calculated by multiplying the installed or prospective capacity of a technology (in kilowatt (kW), megawatt (MW), or gigawatt (GW) etc.) with a defined ratio of employment per kW, MW, or GW. In case of Biomass generation, employment ratios may also be illustrated by employment per gigawatthour (GWh) (Figure 2.4).
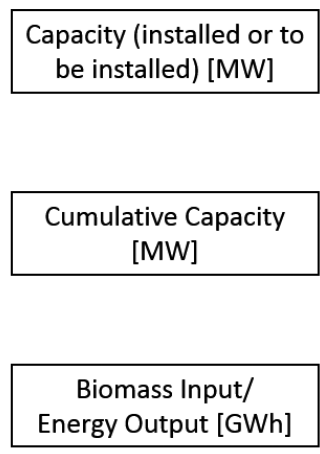

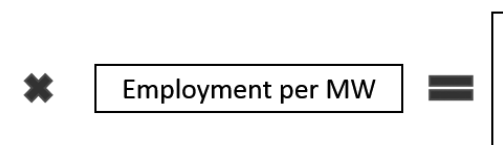

Employment (Manufacturing, Construction, Installation)

\section{Employment (O\&M)}

Employment (Biomass Generation)

Figure 2.4: Calculation of employment using employment ratios (Source: Böhmer et al., 2015:10, modified)

Table 2.4 shows the publications that deal with employment impacts of specific RE technologies by using the employment ratio approach. Regarding the energy type, electricity is the most evaluated energy type, whereas heat is only assessed by 3 papers. Most of the evaluations $(n=10)$ deal with wind power, followed by solar PV $(n=7)$. 
Table 2.4: Studies using the employment ratio approach and evaluated technologies $(n=10)$

\section{Electricity Heat \\ Electricity \\ and Heat \\ Technology Authors}

\section{Number of Evaluations}

\begin{tabular}{|c|c|c|c|c|}
\hline 10 & & & Wind & $\begin{array}{l}\text { Algoso and Rusch (2004); Heavner and Del } \\
\text { Chario (2003); Heavner et al. (2003); Llera- } \\
\text { Sastresa et al. (2010); Madsen et al. (2002); } \\
\text { Moreno und Lopez (2008); SEED Coalition } \\
\text { and Public Citizen's Texas office (2002); } \\
\text { Simons and Peterson (2001); Sterzinger } \\
\text { (2008); ZSW (2012) }\end{array}$ \\
\hline 7 & & & Solar PV & $\begin{array}{l}\text { Algoso and Rusch (2004); Heavner and Del } \\
\text { Chario (2003); Llera-Sastresa et al. (2010); } \\
\text { Moreno und Lopez (2008); Simons and } \\
\text { Peterson (2001); Sterzinger (2008); ZSW (2012) }\end{array}$ \\
\hline 2 & 1 & 2 & $\begin{array}{c}\text { Solar } \\
\text { Thermal }\end{array}$ & $\begin{array}{l}\text { Heavner and Del Chario (2003); } \\
\text { Llera-Sastresa et al. (2010); Moreno und } \\
\text { Lopez (2008); Simons and Peterson (2001); } \\
\text { ZSW (2012) }\end{array}$ \\
\hline 3 & 1 & 1 & Biomass & $\begin{array}{l}\text { Heavner and Del Chario (2003); Moreno and } \\
\text { Lopez (2008); Sterzinger (2008); ZSW (2012) }\end{array}$ \\
\hline 1 & 1 & & Biogas & Moreno und Lopez (2008); ZSW 2012 \\
\hline 1 & & & Landfill Gas & Simons and Peterson (2001) \\
\hline 3 & & 1 & Geothermal & $\begin{array}{l}\text { Heavner and Del Chario (2003); Simons and } \\
\text { Peterson (2001); Sterzinger (2008); ZSW } \\
\text { (2012) }\end{array}$ \\
\hline 1 & & & $\begin{array}{l}\text { Hydrogen, } \\
\text { Fuel Cells }\end{array}$ & Heavner and Del Chario (2003) \\
\hline 1 & & & Hydro & Simons and Peterson (2001) \\
\hline
\end{tabular}

Some authors use employment factors that are derived from the same sources (Table 2.5). Employment factors which have first been used by Simons and Peterson (2001) for example have also been used by Heavner et al. (2003), Heavner and Del Chario (2003) and Madsen et al. (2002). The approach that is used by Sterzinger et al. (2008) in a regional context was originally described by Singh and Fehrs (2001). Moreno and Lopez (2008), Llera-Sastresa et al. (2010), and ZSW (2012) use employment ratios 
which are derived by the comparison of different publications, which use employment factors. The Sustainable Energy and Economic Development (SEED) Coalition and Public Citizen's Texas office (2002) also provides a multiplier for indirect jobs of wind RE deployment which is used by Heavner et al. (2003) and Madsen et al. (2002) for the calculation of indirect jobs. However, the applied methodology for the calculation of this multiplier remains unclear.

Table 2.5: Different approaches of impact assessment using employment ratios

\begin{tabular}{|c|c|c|}
\hline Approach & First Authors & Following Authors \\
\hline $\mathrm{EPRI}^{13}$ & Simons and Peterson (2001) & $\begin{array}{l}\text { Heavner and Del Chario (2003); } \\
\text { Heavner et al. (2003); Madsen et al. (2002) }\end{array}$ \\
\hline REPP & Sterzinger $(2008)^{14}$ & Algoso and Rusch (2004) \\
\hline SEED & $\begin{array}{l}\text { SEED Coalition and } \\
\text { Public Citizen's Texas office (2002) }\end{array}$ & $\begin{array}{l}\text { Heavner et al. (2003) for indirect jobs, } \\
\text { Madsen et al. (2002) for indirect jobs }\end{array}$ \\
\hline $\begin{array}{l}\text { Derived from } \\
\text { literature }\end{array}$ & $\begin{array}{l}\text { Llera-Sastresa et al. (2010), Moreno } \\
\text { and Lopez (2008); ZSW (2012) }\end{array}$ & - \\
\hline
\end{tabular}

An advantage of the methodology is its simplicity. Necessary information consists only of the installed or to be installed rated capacity and the employment ratio. Regarding disadvantages of the approach, large differences between ratios even for the same technologies and lifecycle stages occur. Moreover, it is not sufficient to use employment ratios from other regions, because of different levels of productivity or other specific characteristics (Moreno and Lopez, 2008). Llera-Sastresa et al. (2010) state that even for the same region employment ratios should be used in combination with additional information such as ratios for specific stages in the product cycle e.g. manufacturing, installation and O\&M. This information would strengthen the significance of the approach because reporting the mere number of jobs enables no insight into the quality of jobs, which may be higher paid white- or lower paid bluecollar jobs and hence generate different earnings and economic impacts. Additionally, some regions may not have an available trained workforce for certain lifecycle stages (e.g. engineers for the design of RE technologies), which is assumed in the calculation of the employment ratios.

13 Electric Power Research Institute (EPRI)

14 REPP approach has methodologically been described by Singh and Fehrs (2001) for the Renewable Energy Policy Project (REPP), Sterzinger (2008) is a REPP publication as well 
Many authors use employment ratios without referring to the methodology which has been used to deduce the employment factors. An approach to estimate the ratios may be to evaluate the working hours for every activity in the product cycle of a specific technology and divide it by the typical working hours of a period (usually a year), which yields person-years of full-time equivalent jobs per rated capacity of a technology. Such evaluations are accompanied by extensive data assessment and comprehensive surveys. The REPP approach which is used by Sterzinger (2008) or Algoso and Rusch (2004) for example is based on the inquiry of Singh and Fehrs (2001) that assesses the working hours of various RE industries.

When using employment ratios over a period of time (e.g. in a future scenario) some authors use fixed employment ratios over the whole time (e.g. Simons and Peterson, 2001 or Madsen et al., 2002). Other authors such as Heavner and Churchill (2002) or SEED Coalition and Public Citizen's Texas office (2002) assume a simple cost reduction due to learning effects and productivity, but do not point out at which specific stage in the lifecycle cost reductions occur. For instance, it is assumed that costs decrease by $10 \%$ for the construction period and 5\% for O\&M per year (Heavner and Churchill, 2002).

Conclusively, employment ratios are an easy-to-use-instrument to evaluate the employment impacts of RE development in a region. However, ratios should be used with caution and further information is needed to make a more transparent analysis possible. It should be pointed out which technologies and which part of the product lifecycle have been assessed in order to enable a transparent comparability of factors and an adaptability of employment factors if changes occur (e.g. new production technology which enables an enhanced productivity in the manufacturing sector). Moreover, because of dynamic markets, ratios should be assessed up do date to take into account cost changes (Section 2.3). Finally, cost reductions due to technological learning should be included when using ratios for future scenarios. In any case, the application of employment ratios for employment assessments in future scenarios should be scrutinised with regard to the advantages of other methods. 


\subsubsection{Supply chain analysis}

Supply chain analysis is a methodology for assessing the economic impact of RE deployment by evaluating the supply chain of individual technologies ${ }^{15}$. The supply chain which consists of subordinated tiers is drawn up and the economic impact of each tier is assessed. By assuming typical project investment and operating costs for specific RE technologies, which may also include different plant sizes, the benefits of RE plant developments can be calculated. Moreover, investment and operating costs may also be interpreted as revenues of enterprises which are part of the tier 0 level, like the turnkey contractor. These revenues may be broken down into material costs, labour costs, and revenues, including taxes. By assessing the net earnings of the employees, the net revenues of business proprietors, and taxes, the economic impact of a RES technology on tier 0 can be estimated. Additionally, material costs of tier 0 suppliers (e.g. turnkey contractors) can be interpreted as revenues of tier 1 suppliers (e.g. suppliers of the wind turbine) (Figure 2.5). The costs have to be broken down for each of the suppliers on tier 1 level and the material costs of these suppliers may also be interpreted as revenues of tier 2 suppliers. To assess the businesses that are involved in the RE industry in a region that may potentially supply the regional demand, which leads to economic impacts, a detailed analysis of the regional businesses is needed, because they are not classified as RE businesses in official statistics in most countries (cf. Section 2.4.3). A more comprehensive overview of supply chain analyses is provided by Breitschopf et al. (2011).

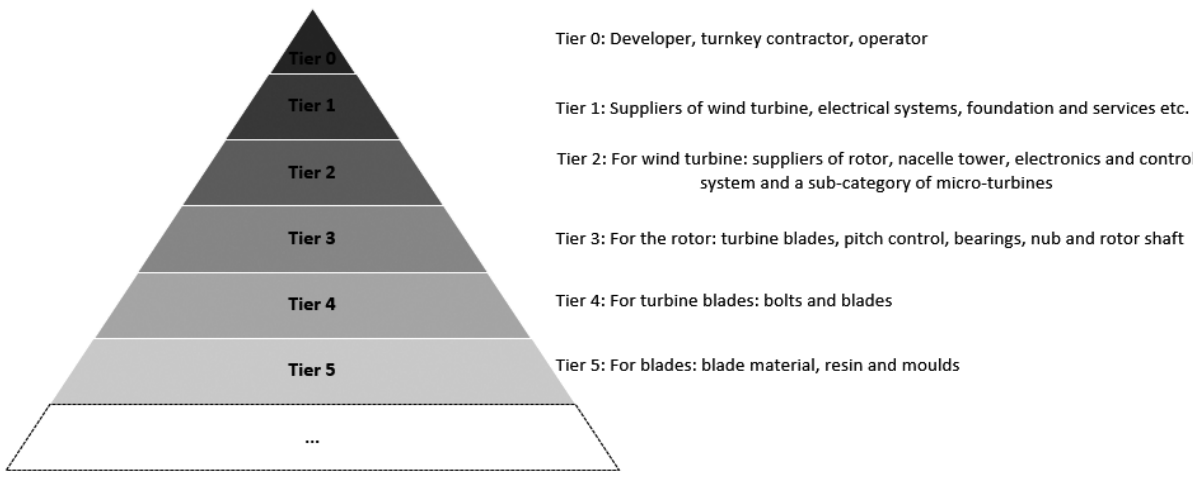

Figure 2.5: Example of a supply chain pyramid for wind and exemplary elements (Source: DTI, 2004:11, modified)

15 The term 'supply chain analysis' is used in Breitschopf et al. (2011) for the approach applied by DTI (2004) and Böhmer et al. (2015) for the approaches used in DTI (2004) and Aretz et al. (2013) (which contains the IÖW model). We follow that terminology, which could also be named analysis of supply chains (Böhmer et al., 2015), because various supply chains are analysed. 
One of the first studies using a supply chain analysis in the context of RES was conducted by DTI (2004) on a national level. For regional supply chain analyses, only studies dealing with the situation in Germany have been identified. The model most often used is the WEBEE (Modell zur Ermittlung von Wertschöpfungs- und Beschäftigungseffekten durch Erneuerbare Energien; English: Assessment model for value added and employment effects in the context of renewable energies) approach, which was originally been developed by Hirschl et al. (2010) and was first called the IÖW model (Table 2.6).

Table 2.6: Different supply chain approaches

\begin{tabular}{cll}
\hline \multicolumn{1}{c}{ Approach } & \multicolumn{1}{c}{ Lead Author } & \multicolumn{1}{c}{ Following Authors } \\
\hline IÖW/WEBEEapproach & Hirschl et al. (2011) & $\begin{array}{l}\text { Bost et al. (2012); Hirschl et al. (2015) }{ }^{17} \text {; Meyer et } \\
\text { al. (2011); Weiß et al. (2012); Bröcker et al. (2014) }\end{array}$ \\
Own & BMVBS (2011) & \\
& Finus et al. (2013) \\
\hline
\end{tabular}

The model contains a detailed analysis of 34 different supply chains of various RES technologies (Hirschl et al., 2015) and includes impacts for all stages in the specific product lifecycle, including value added impacts for operators, wholesale trade, manufacturers etc.

The advantage of supply chain analysis is the provision of an exact view of the RE industry in the region. It helps to clearly identify the value added generated by industries involved in RE related business activities, due to the bottom-up approach accounting for the installed capacity in a region and the generated economic impacts. Unlike in a top-down approach, there is no disaggregation of statistical sectors needed because involved industries are defined as RE related due to their activity in the RE industry.

By using the material costs of suppliers and interpreting them as revenues of their suppliers there is no double counting. Moreover, changes in prices which occur rather fast in the dynamic RE industry can be easily integrated by adjusting the costs for specific industries in the supply chain. Decreasing system prices in the context of

16 IÖW/WEBEE approach was first described methodologically by Hirschl et al. (2010)

17 The studies of Hirschl et al. (2015) and Bröcker et al. (2014) contain an IO model, as well as a supply chain analysis, (author's own graph) 
economies of scale of increasing plant sizes may also be regarded by taking into account different cost structures for specific plant sizes. The approach can be applied in several regions in a country or market, provided that no huge differences exist in technology costs or productivity in industries. The disadvantages of the approach lie in the fact that a lot of detailed information on specific costs of technologies and internal cost structures, such as labour costs and material costs in various industries, is needed in order to conduct a comprehensive analysis. On the other hand, the construction of a comprehensive economic model that calls for even more data gathering (Section 2.4.3 and Section 2.4.4) is not necessary.

Additionally, only inputs which are RES related are taken into account. Other inputs like, for example, the value added of the real estate industry that leases property to, for instance, energy service companies (ESCOs) are not included in the approach. However, that could be overcome by combining the supply chain analysis with an input-output model (Section 2.4.3), which is done by, for example, Bröcker et al. (2014) and Hirschl et al. (2015). The economic impacts of inputs of enterprises which are not directly related to RE related economic activities are then taken into account.

Moreover, if regional industries should be identified to satisfy the demand in a region, a detailed analysis of businesses is necessary, which can be resource- and timeconsuming. However, the same obstacles exist, when the RE industry is assessed by an input-output model with a disaggregated RE industry sector (Section 2.4.3).

\subsubsection{Input-output modelling}

Input-output (IO) modelling is an instrument for assessing the interactions in an economy which dates back to the work of Leontief (1936, 1951). IO tables show the flow of goods and services between the industries in an economy from their production to their final use. By illustrating an 10 model in the Leontieff inverse matrix the values in the columns, which are called multipliers, show what all industries (inclusively a given industry) have to produce directly or indirectly (i.e. as inputs) so that the given industry can generate one additional unit for final demand (Holub and Schnabl, 1994). Concerning final demand, a differentiation between consumption, investment, and export may also be provided (Statistisches Bundesamt, 2010).

By using $\mathrm{IO}$ tables, it is possible to calculate the gross output in an economy, as well as the value added, by subtracting the inputs of an industry from its gross output. Moreover, the value added can be divided into different sub components such as employee and business income including taxes of businesses. Furthermore, it is 
feasible to transform the tables with additional information and, for instance, evaluate the directly and indirectly employed employees in the industries under investigation (Moosmüller, 2004). The mostly used form of IO models in the context of the regional economic impact of RE are static IO models which remain unaltered over time. A key assumption of these models is that the input of a sector is proportional to its output, so that economies of scale, changes in prices, technical progress and increasing or decreasing productivity are not considered (Moosmüller, 2004), as well as potential substitutions of goods and services (Christ, 1955).

National IO output tables exist for OECD member states (OECD, 2017) and several other countries. However, by assessing the regional impacts of RES, a national input-output table cannot be used and a Regional IO Table (RIOT) which represents the flows of goods and services in a regional economy should be developed. Those RIOTs can be derived from national IO tables by calculations, (by transforming the tables using for example the LQ or, FLQ approach of Flegg and Thomo (2013), which is a nonsurvey approach that is used for example in the Regional Input-Output Modelling System (RIMS) II model or Hirschl et al., 2015). A more comprehensive approach is the construction of RIOTs with extensive surveys of the regional economy (e.g. Coon et al., 1985). Some RIOTs combine survey and non-survey data from associations such as national statistic agencies or economic development organisations. This is called a hybrid approach (Jones et al., 2010). In the sample, the study of Fanning et al. (2014) relies on an 10 model that has been developed with such a hybrid approach (Jones et al., 2010).

After the development of a RIOT, the share of goods, which are sourced locally, has to be estimated by using industry data or expert estimates and the economic impact of a change in final demand for a specific industry (e.g. the wind power industry) can be calculated.

One of the most prominent impact assessment instruments in the context of RES which is based on RIOTs is the Job and Economic Development (JEDI) model, developed by the US American National Renewable Energy Laboratory (NREL) (Goldberg et al., 2004). With the JEDI model it is possible to calculate the regional economic impacts of RE deployment like employee earnings, gross output or jobs at the state level in the US (NREL, 2012). The model contains a detailed cost analysis of different technologies and can be applied to measure the impact in different industries. The multipliers used in the model are provided by the IMPLAN (IMpact analysis for PLANning) system, which is a computer-based IO model that was originally developed for the USDA Forest Service and is currently hosted by the IMPLAN group (IMPLAN, 2015a). Originally developed 
for wind power, it has been adapted in order to be suitable for assessing several other energy technologies such as biofuels, geothermal, coal, concentrating solar power, marine and hydrokinetic power, natural gas, and solar PV power plants (NREL, 2015). It is also possible to use default values for local shares of inputs or to enter one's own information (such as specific construction or O\&M costs) into the model. An analysis on county level is also possible, but multipliers, which are available from IMPLAN, have to be inserted by the user independently. Local shares of inputs should be estimated by experts' judgement, surveys or data from associations because JEDI default values are similar among most of the states and only provide a rough estimation of the characteristics of the local economy (NREL, 2015.).

IMPLAN IO models are derived from many sources including the U.S. Census Bureau, the Bureau for Economic Analysis (BEA) and from existing IO tables (BEA Benchmark IO tables) (IMPLAN, 2015b) and provide multipliers for every county in the US. The availability of such a tool leads to its wide application for impact analyses at a regional level. That becomes evident in the sample, since 19 (82\%) of US publications use data originally from IMPLAN or the JEDI model with data from IMPLAN (Table 2.7).

Due to the fact that IMPLAN has widely been applied it is possible to compare studies, because of the same applied methodology, which is a clear advantage. However, weaknesses and limitations of the model such as lack of disaggregation of the RE industry in the IMPLAN IO model, or the negligence of foreign trade flows in the gravity model, also occur in the reviewed studies.

In contrast, some US publications use other multiplier data from RIMS II, REMI or the IO model of North Dakota of Coon et al. (2012). Fanning et al. (2014) use an IO model for Wales which has been developed by Jones et al. (2010). Madlener and Koller (2007) use the national IO table of Austria to describe the effects on the national economy by the deployment of RES in Vorarlberg. The German publications use models, which have been developed by their respective organisations (e.g. DIW, 2014a) and are derived from national IO tables. 
Table 2.7: Authors using different IO models for impact assessment and analysed regions

\begin{tabular}{|c|c|c|c|}
\hline IO Model & Authors & Country & Region \\
\hline \multirow{7}{*}{ IMLPAN } & Carlson et al. (2010) & US & 8 counties in Illinois and Illinois \\
\hline & $\begin{array}{l}\text { Deyette and Clemmer } \\
(2005)\end{array}$ & US & Texas \\
\hline & $\begin{array}{l}\text { Deyette and Clemmer } \\
\text { (2006) }\end{array}$ & US & Washington \\
\hline & ECONorthwest (2002) & US & Kittitas \\
\hline & GAO (2004) & US & $\begin{array}{l}\text { Farms and rural communities } \\
\text { in } 11 \text { different counties in } \\
\text { California, Texas, Minnesota, } \\
\text { Colorado, and lowa }\end{array}$ \\
\hline & $\begin{array}{l}\text { Kildegaard and Myers- } \\
\text { Kuykindall (2006) }\end{array}$ & US & Big Stone County \\
\hline & Timmons et al. (2007) & US & $\begin{array}{l}\text { Massachusetts and an } \\
\text { aggregated region ( } 5 \text { counties) }\end{array}$ \\
\hline \multirow{12}{*}{ JEDI/IMPLAN } & $\begin{array}{l}\text { A Renewable America } \\
(2015)\end{array}$ & US & Washington \\
\hline & Coover et al. (2013) & US & Utah \\
\hline & Costanti (2004) & US & 6 counties in Montana \\
\hline & Lantz (2009) & US & Nebraska \\
\hline & $\begin{array}{l}\text { Lantz and Tegen (2008a-I) } \\
\text { Lantz and Tegen (2009a-c) }\end{array}$ & US & $\begin{array}{l}\text { Arizona, Idaho, Maine, } \\
\text { Montana, New Mexico, Nevada, } \\
\text { Tennessee, North Carolina, } \\
\text { Massachusetts, Indiana, } \\
\text { Pennsylvania, South Dakota, } \\
\text { Utah, West Virginia, Wisconsin }\end{array}$ \\
\hline & Loomis (s.a.) & US & Livingston County and Illinois \\
\hline & Loomis et al. (2010) & US & Illinois \\
\hline & $\begin{array}{l}\text { Rategui and Hendrickson } \\
\text { (2011) }\end{array}$ & US & Texas \\
\hline & Rategui and Tegen (2008) & US & Colorado \\
\hline & Ratliff et al. (2010) & US & Utah \\
\hline & Slattery et al. (2011) & US & Texas \\
\hline & Torgerson et al. (2006) & US & Umatilla County \\
\hline
\end{tabular}


Chapter 2

Table 2.7: Authors using different IO models for impact assessment and analysed regions (continued)

\begin{tabular}{llll}
\hline \multicolumn{1}{c}{ IO Model } & \multicolumn{1}{c}{ Authors } & Country & \multicolumn{1}{c}{ Region } \\
\hline \multirow{2}{*}{ RIMS II } & Stoddard et al. (2006) & US & California \\
& Black and Veatch (2004) & US & Pennsylvania \\
\hline \multirow{2}{*}{ DIW } & DIW (2014a) & Germany & Brandenburg \\
& DIW (2014b) & Germany & North-Rhine Westphalia \\
\hline REMI & Weisbrod et al. (1995) & US & lowa \\
Coon et al. (1985) & Coon et al. (2012) & US & North Dakota \\
Jones et al. (2010) & Fanning et al. (2014) & UK & Wales \\
National IO Table & Madlener and Koller (2007) & Austria & Vorarlberg \\
& Bröcker et al. (2014) & Germany & Schleswig-Holstein \\
\cline { 2 - 3 } Own & Hirschl et al. (2015) & Germany & Germany and federal states \\
& Ulrich et al. (2012) & Germany & 16 German federal states \\
\hline
\end{tabular}

Unfortunately, industries in the 10 model may be displayed at a high aggregation level (e.g. manufacturing industry instead of wind power industry) and multipliers of a more general category, such as manufacturing are used instead of taking specific inputs of the industry being investigated (e.g. wind power plant manufacturing) into account. There is no statistical categorisation of the RE industry concerning common national statistics as the RE industry is aggregated with other industries like fossil-based electricity or energy generation. Hence, inputs of the RE industry into the economy are not clearly categorised in 10 tables. Some studies exist which deal with this issue by disaggregating original 10 table sectors which contain electricity generation into new sectors, for example electricity generation from e.g. wind, solar PV. This is accomplished by extensive data gathering (Lehr et al., 2015).

According to the assumption of static $1 \mathrm{O}$ models that inputs have to be proportional to the output, several potential economic developments are neglected. Firstly, economies of scale, increasing productivity, and technical improvements that have an impact on the production volume or prices are not represented, which is a disadvantage in dynamic markets such as the RE industry. Secondly, there are no limitations in the market volume resulting in the possibility of overestimated production capacities

$18 \mathrm{REMI}$ is a model which can be categorised as an 10 model or a general equilibrium model (REMI, s.a.) 
(Moosmüller, 2004). Furthermore, input of goods and services are unchangeable, so that a substitution of goods as an effect of e.g. innovative production processes is not applicable (Madlener and Koller, 2007). Another disadvantage is the availability of IO tables at a sub-national scale (DIW, 2014a) which is especially a challenge on a rather small regional scale where non-survey based 10 models suffer from a lack of accuracy (BMVBS, 2011).

Moreover, due to the fact that comprehensive survey-based data assessment and processing is very extensive, the results are published with a delay after the original data has been assessed. This also does not take into account the dynamics of the RE industry. For a more comprehensive overview of strengths and weaknesses of IO models refer, for example, to Miller and Blair (2009).

\subsubsection{Computable general equilibrium models}

Computable general equilibrium (CGE) models are computerised simulation models, based upon the general equilibrium theory and normally start with a current (or business-as-usual) equilibrium that is challenged by a change (e.g. a policy shift that promotes increasing RES deployments), inducing impacts that lead to an alternative general equilibrium (Babatunde et al., 2017).

Typically, CGEs include anticipation about the actions of economic agents (e.g. households or enterprises) aiming to achieve individual utility maximisation (Bergs and Peichl, 2006; Böhringer and Löschel, 2006). Some CGE models contain further assumptions like non-market clearing because of unemployment (Gilmartin and Allan, 2015). The model assumptions are linked to economic datasets, like a social accounting matrix $\left(\mathrm{SAM}^{20}\right)$. While IO tables illustrate the flow of goods and services from production to final demand (Section 2.4.3), SAM based CGEs illustrate the interrelations between supply and demand, showing the distribution of income of specific economic agents (e.g. enterprises or the public sector), thus providing a picture of the economy in a fully integrated approach (Cansino et al., 2013).

Characteristics of the model are elastic prices which are dependent upon supply and demand (Böhringer and Löschel, 2006), while in static IO models, increasing or decreasing demand does not have an influence on prices and wages (Allan et

20 There are also CGE models which are based upon 10 models (e.g. Gilmartin and Allan 2015). However, as the aim of this section is to highlight the differences from IO based models, only literature CGEs with integrated SAMs are taken into account. 
al., 2008), which is also the case in the other impact assessment approaches. Since additional variables like migration may be integrated in the model, the approach has the potential to evaluate the impacts of changing conditions in time like an increasing supply of workforce that may have a negative impact on wages (Allan et al., 2014).

Therefore, the approach is the only approach among the evaluated methodologies where market mechanisms and agent behaviour are taken into account. In summary, the approach

"allows one to study the changes in the spheres of production and consumption as well as in income distribution, in response to changes in a given economic policy, as these models explicitly include a representation of the framework of interdependencies among all markets in an economy" (Cansino et al., 2013:27).

A further description of specific characteristics of CGEs and their application in regional impact analyses is provided by Partridge and Rickman (2010).

SAM based CGE models have not been used for a regional economic assessment of RES on a regional scale as frequently as the other approaches since only a few publications using a SAM based CGE have been identified (Table 2.8). This goes along with Cansino et al. (2014) stating that most economic assessments in the field of RES are based upon an IO modelling approach instead of CGE models, which is also the case in the reviewed literature sample.

Table 2.8: Authors using different economic data models in CGE approaches and analysed regions

\begin{tabular}{lll}
\hline Economic Data Model & \multicolumn{1}{c}{ Authors } & \multicolumn{1}{c}{ Region } \\
\hline SAMAND & Cansino et al. (2013); Cansino et al. (2014) & Andalusia \\
AMOS & Gilmartin and Allan $(2015)^{21}$ & Scotland \\
Own & Trink et al. (2010) & $\begin{array}{l}\text { East Styria and rest of } \\
\text { Styria }\end{array}$ \\
\hline
\end{tabular}

21 The studies Allan et al. (2008), Allan et al. (2014) are not included in the sample because differences between Gilmartin and Allan (2015) were low as they focused on the economic effects of the marine energy sector in Scotland using a CGE model as well. 
Gilmartin and Allan (2015) use a CGE model for the assessment of marine energy developments in Scotland and compare the results to a study where an IO model has been used. This comparison shows the differences in CGE models and approaches, where the impact of regional supply and demand on wages and prices are not taken into account.

In comparison to the results of the IO model, Gilmartin and Allan (2015) find that IO models may overrate the regional employment impacts especially in the short term (i.e. the investment stage) and underrate the effects in the long term. This is explained by the IO model's characteristic that labour supply is elastic and an increase in demand has no effect on the regional labour market. However, according to the CGE model assumptions, an increasing demand in RES-related economic activities leads to rising wages in the respective industries if there is no sufficient labour supply. That induces a crowding-out of workforce from non-RE related industries to RE-related industries as a result and therefore lower total employment impacts as in the IO model. In the long term, due to adaptations of the supply side by, for instance, migration into the region and a decreasing labour demand after the investment stage, wages fall which leads to positive economic effects in the labour market (Gilmartin and Allan, 2015).

Therefore, the advantage of CGE models consists of taking regional supply and demand and the impact of increasing regional demand into account which makes the approach particularly valuable for assessing future developments which are "large relative to the host economy" (Allan et al., 2008:2737).

However, due to the fact that a global market and a global division of labour for certain RES technologies (e.g. solar PV) (Binz et al., 2017a) exist, material prices are more dependent upon global or national market developments instead of the regional market. An increase in regional demand therefore may not have a very significant effect on regional prices for RES technologies if the demand stays stable for the rest of the world. In the case of biomass, Trink et al. (2010) support that statement by illustrating that a higher demand for domestic biomass may only have an effect in a protected market. In an international market however, regional goods may be substituted by imports which does not have an increasing effect on the regional price (Trink et al., 2010). Therefore, the effects of regional demand may be negligible at the manufacturing stage.

Nevertheless, in the case of employment especially in the installation and O\&M stage which is supposed to be taken over by local employees - depending upon the specialisation of the local workforce though (Llera-Sastresa et al., 2010) - the advantage 
of CGE models is the fact that competition between non-RE-related and RE-related industries and a crowding-out of employees are taken into account. However, that may be more important for larger regions than on a local or small regional scale due to a limited supply side and an increased labour demand may be compensated by commuters from neighbouring regions.

Further advantages of SAM based CGEs is that specific economic actors such as households are considered, which allows the evaluation of the effects of higher energy prices because of RES technologies. That is illustrated by Trink et al. (2010) for the case of biomass heating which may lead to negative welfare effects for consumers although the net regional GDP is positive due to increasing heating costs. CGEs therefore provide a more comprehensive illustration of a regional economy than the other approaches.

Nevertheless, some assumptions of applied CGE models should be questioned critically like "perfect sectoral mobility" (Allan et al., 2014:126), which does not adequately take into account the specialisation of the workforce for economic activities related to RES. Moreover, cost reductions because of learning effects are also not integrated in, for example Gilmartin and Allan (2015) despite the fact that they may be significant in some RES industries (Schröder et al., 2013), which according to the model's assumptions, also have a positive effect on employment. A challenge of applying SAM based CGEs consists in data availability since according to Jahn (2014) SAMs are in many cases not even available on a national scale.

\subsubsection{Other methods}

Other methods of impact assessment which rely mostly on surveys of the RE industry have been used by Faulin et al. (2006), or The American Solar Energy Society (2008) and Bezdek (2007), that both rely on the same ASES/MISI22 approach or Tegen (2006), who assesses economic benefits in $\$ / \mathrm{kWh}$ (Dollars per kilowatt-hours), using cost information from different sources including the JEDI model. These methods will not be discussed in the following. 


\subsection{Guideline towards regional RE impact assessment}

A potential first step of a regional economic impact assessment consists of choosing and defining a region (Figure 2.6). Such a definition should contain a clear distinction of the regions' boundaries by ideally choosing official administrative units which are classified and internationally comparable in order to enable a comparison of regions and economic impacts.

When assessing regional impacts of RES, certain regional characteristics may be considered that may conceivably limit the comparability of regions. Therefore, that step should include a first analysis of the region of interest. First of all, geographical conditions which have an impact on the operation of RES should be regarded. For instance, the natural conditions like irradiation for solar energy or wind conditions for wind power may define the energetic and economical (which may vary across countries because of different system prices) performance of a technology. For solar energy, the natural conditions vary between Northern Germany (e.g. full load operation hours of solar PV plants in Lower Saxony were 844 h on average in 2014 (Agentur für Erneuerbare Energien, s.a.b)) and Southern Germany (full load operation hours of solar PV plants in Baden-Württemberg were 961 h on average in 2014 (Agentur für Erneuerbare Energien, s.a.c)). In terms of comparability, this leads to higher economic benefits for solar PV operators in Southern Germany provided that system and O\&M costs are the same. Henceforth, the economic benefits of a technology, may be illustrated as economic benefits per unit of energy generated (e.g. $€ / M W h$ ), as an addition to the benefits of the installed capacity (e.g. MW), to take into account the natural conditions of locations.

Furthermore, regional consumption patterns may play a role which may be exemplified by the most energy-consuming processes regarding residential consumption; while in some (northern) regions, technologies for heating may be essentially because of climate conditions, in some (southern) regions, cooling may be more important than heating (Shah et al., 2008), which has an impact on the RES technologies' applicability and demand in a region. Moreover, concerning consumption, demographic criteria like the population number and population density (and concentration) in a region should be considered. The possibilities for applying certain technologies may depend on the level of consumption and the concentration (e.g. when applying district heating solutions (Dötsch et al., 1998)) of the population.

The concentration of the population in a region may - in addition to the size - also define the potential to install certain technologies like wind power or open space 
solar PV plants, which are space intensive. Other criteria like nature conservation or water protection may also limit available spaces for the installation of various RES technologies.

Moreover, there is a need for an analysis of the local economy. If specialised enterprises, which are able to provide services for the installation and the operation of RES are located in a region, there is a chance to create more regional economic benefits, when these enterprises are integrated in value added activities of RES in a region.

In conclusion, when defining and assessing a region or evaluating a comparison across regions, these regional characteristics should be considered.

Furthermore, a precise definition of technologies being assessed, including the energy type (i.e. heat or electricity) that is generated by the technology, should also be provided. Additionally, a clear definition of the evaluated time period should be given. When assessing RE development which is installed within the time period, cost developments for specific technologies should be regarded as well. Moreover, different life-cycle stages (i.e. e.g. manufacturing, installation etc.) should be precisely defined. The impacts that are assessed rely on the research question. While in some cases only employment effects are evaluated, further economic effects may also be taken into account.

Figure 2.6 illustrates the steps which ideally need to be taken to perform such an analysis; however, the order is a proposal that may vary in some cases.

Before choosing the evaluation method, it is necessary to compare the impact assessment approaches and to select the most suitable approach for the individual study, as each method has its strengths and weaknesses.

Based upon the framework of Figure 2.6, Figure 2.7 shows in which specific situations (e.g. indicators: size of the region, time, and type of impacts), the advantages of the evaluated methodologies are especially useful, and in which circumstances the application of a specific approach is the most efficient solution.

For the indicator region, small refers to the local and small regional scale, whereas large covers all larger regions on the sub-national scale. A threshold for large regions can be spatial units above the European NUTS 3 level or US county level depending on the specific regional situation. 


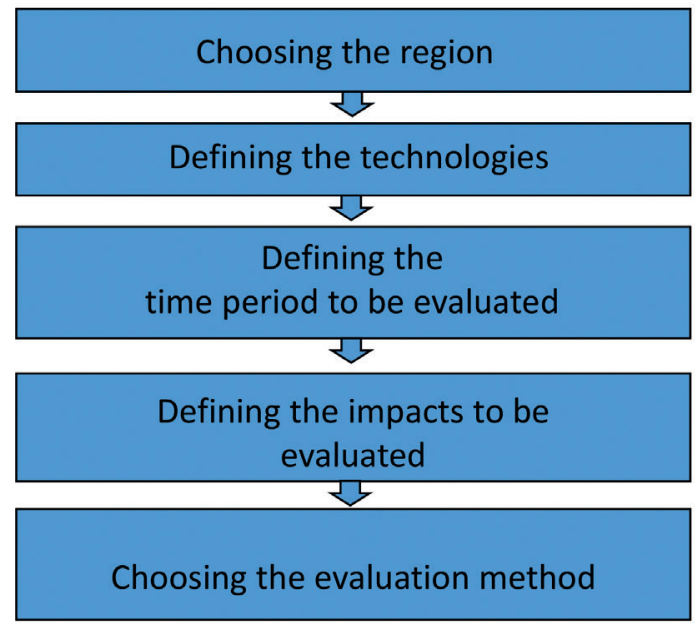

Figure 2.6: Steps to be taken when assessing the regional economic impacts of RE

The indicator time refers to the period where RES deployments take place. Current analyses cover already installed plants whereas Future analyses deal with RES deployments in future periods.

As employment is the most often assessed indicator in impact assessments and some research may consider an evaluation of employment impacts as sufficient, the main assessment impacts are employment or further economic impacts (Table 2.2).

The situation where the strengths of the specific methods are most valuable is illustrated by an unbroken line and the promising alternative applicability of an approach is illustrated by a dotted line.

Analytical models like supply chain analyses and employment ratios may be especially beneficial on a local scale and in relatively small regions, where no economic models like a RIOT and a SAM exist, since constructing a survey-based RIOT or CGE model solely for the case of renewable energy impact assessment is very resource intensive and applying non-survey-based models in rather small regions may lead to imprecise results (Section 2.4.3).

If only the current situation is assessed, there is no need to take future regional labour supply and price changes into account and existing data can be used. Therefore, an employment factor approach is the most efficient approach for assessing employment impacts of the current situation in small regions (orange unbroken line). However, in terms of reliability, employment factors should be up-to-date and assessed in the 
same region where an analysis takes place so that they are open to scrutiny. A best practice example using employment ratios is provided for instance by Llera-Sastresa et al. (2010).

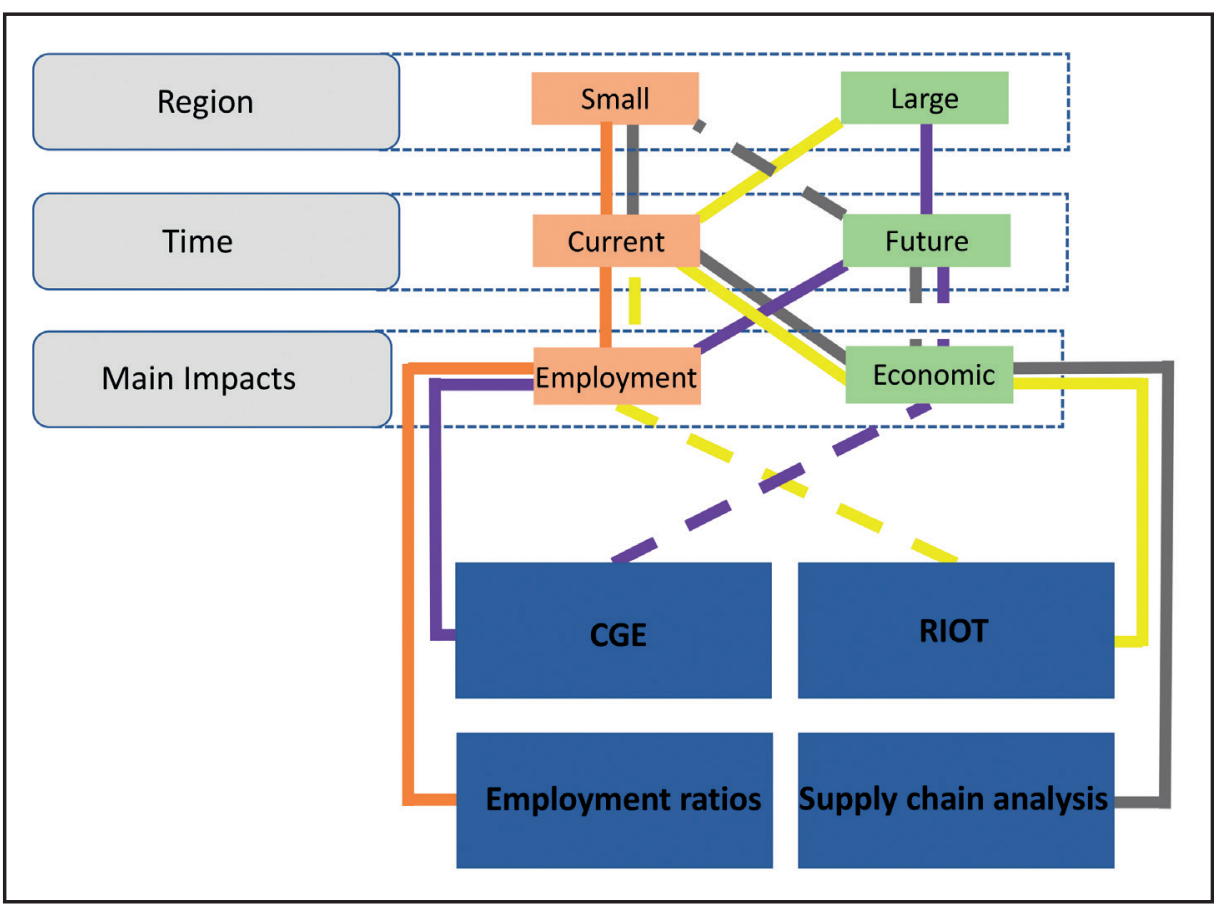

Figure 2.7: Most suitable (unbroken line) and promising alternative (dotted line) approaches, depending upon the size of the region, reference time, and types of impacts

The advantage of supply chain analyses becomes especially evident in the analysis of current economic effects in small regions (grey unbroken line). As for employment ratios, there is no need to have an economic model available, a disaggregation of sectors is not necessary, and the approach allows economic benefits beyond employment to be taken into account. Allied to the benefits of analytical methods on a small regional scale for current assessments, the approach may also be used as a potential alternative to CGEs to evaluate future economic effects on that scale (grey dotted line) since scarce resources (e.g. workforce or goods) on a small regional scale may be compensated by international trade or commuters from outside the region. Furthermore, supply chain analyses are the most transparent tool if economic effects of specific RE technologies (e.g. wind power, cf. Figure 2.5) are evaluated if - as in most cases - economic models are not finely disaggregated. Supply chain analyses can be more easily adapted than employment factors, RIOTs, or CGE models and changes which occur in the supply chain (e.g. changes in prices, substitution of goods) can be 
integrated with limited effort. A best practice example of an impact assessment by conducting a supply chain analysis is provided for instance by Hirschl et al. (2010).

Typically, RIOTs provide a comprehensive analysis of the flow of goods and services in an economy because all inputs of industries are taken into account in the model and not just RE related inputs like in the supply chain analysis approach. Moreover, it is possible to assess employment effects with an $1 \mathrm{O}$ model, so that it provides the same solution as the employment factor approach. IO models may also be used to measure disinvestment if these decline, due to RE development (e.g. coal mining), provided the energy generation sector is sufficiently disaggregated. A disadvantage of most IO models compared to the employment factor approach and the supply chain analysis, is that data is mostly not up-to-date because of the intensive process of data gathering. Moreover, regional 10 tables are not available for most regions (except for the US, where a series of models are available) and non-survey methods of constructing IO models may suffer from a lack of precision in small regions (Section 2.4.3). Because of these constraints and due to fixed coefficients, which inadequately take future market dynamics into account especially concerning employment, other methods are more suitable for evaluating impacts on a small regional scale and future impacts in large regions.

Additionally, if RE industries are not disaggregated (which depends on the aggregation level of the IO table used), impacts of specific technology segments (e.g. small roof top solar PV) are hard to define. A suitable approach may be coupling a supply chain analysis with a regional $1 \mathrm{O}$ model, because a disaggregation of RE related economic activities in the $\mathrm{IO}$ model is not obliged since effects of RE- related activities are covered by the supply chain analysis, which is done for example by Bröcker et al. (2014) and Hirschl et al. (2015). Nevertheless, because of their comprehensive illustration of the economy, IO models are a suitable tool in large regions since there may be surveybased IO tables available or, in case of a derivation from national IO tables, inaccuracies in RIOTs may not be as significant as on a small regional scale.

In conclusion, for an impact assessment of current renewable energy developments beyond employment in larger regions, IO tables are the most suitable approach (yellow unbroken line). As it is possible to assess employment with the approach as well, another potential alternative is the assessment of current employment in large regions (yellow dotted line). A best practice example of an impact assessment by using RIOTs is provided, for instance, by Coon et al. (2012). SAM based CGE models extend the benefits of an 10 model regarding a comprehensive impact analysis by taking future market dynamics and distribution effects into account, enabling a potential 
view of future impacts. Due to the static nature of the other approaches that do not take into account the regional supply side, the model is especially beneficial for future assessments, since in historic or current data assessments these benefits of CGEs become obsolete.

CGE models are especially suitable for assessing employment effects because the impacts of increasing demand on wages and employment are taken into account. For some stages in the supply chain, especially manufacturing, a limited regional market may not exist (Section 2.4.4) but for other stages (e.g. construction and installation or O\&M, with a lower level of specialisation) the method has its benefits in comparison to the other approaches. However, future learning effects which have a negative impact on the workforce demand should be taken into account. These benefits occur especially in larger regions, where an increased demand may not be compensated by commuters from outside the region (purple unbroken line).

Another benefit beyond the evaluation of employment effects lies in the fact that SAM based CGEs illustrate distribution effects which allows the negative effects of rising energy prices for consumers to be taken into account. They are therefore a beneficial alternative to 10 models when taking further economic evaluations (purple dotted line) into account. In conclusion, SAM based CGEs are the most comprehensive tool for assessing the overall effects of a transition to renewable energies.

Nevertheless, it should be noted that the framework provides a generalised picture assisting in choosing a suitable impact assessment. Further variables, such as resource constraints (e.g. time, money), regional data availability (e.g. existing RIOTs), the technology with its specific market dynamics, the specific stage in the value chain which should be assessed, and the extent of developments, affect the assessment method selection. The extent of developments is an indicator for the usefulness of CGEs, since shortcomings of approaches which do not integrate supply and demand are more apparent in large developments which have a significant impact on the regional economy. Moreover, the extent of impacts is important as SAM based CGEs allow income distribution effects for households to be taken into account, which is not included in the other approaches.

After choosing a method, data sources and the methodology including its strengths and weaknesses should clearly be explained since especially the complexity of a CGE may be considered as a "black-box" (Böhringer et al., 2003:1) for inexperienced practitioners in the field of economic modelling. When conducting a comprehensive analysis of economic impacts, the effects generated by installed RE capacities in the 
region, as well as regional enterprises which are part of the RE industry, should ideally be taken into account to cover impacts generated by domestic as well as external demand.

To study the regional chances as well as challenges due to energy transformation, potential economic losses in conventional energy generation industries due to increasing renewable energy developments should also be taken into account in comprehensive regional studies. This especially affects regions where conventional energy generation takes place and supports regional decision makers by evaluating how losses may be compensated by renewable energy developments.

All the studies reviewed focus on relatively clearly assessable RE-related economic benefits (e.g. through job generation), and most often lack a comprehensive analysis of additional benefits, such as changes in regional economic perspectives (e.g. leading to improved export chances), innovation dynamics and spill-overs, as well as further macro-economic effects through e.g. improved public health (due to reduced air pollution) and other factors. Therefore, from a comprehensive regional economic evaluation perspective, further assessments could be integrated in an analysis. Presenting just the results or impacts may not sufficiently show how regional businesses may profit from RE developments in general and, specifically, the developments of the RE industry in a region. Therefore, regional collaboration between research organisations, RES businesses and industries, as well as aspects of the functional economic specialisation (Brachert and Titze, 2012) of a region, potentially enhance knowledge spillover effects and employment growth (Frenken et al., 2007) and may lead to innovations (Asheim et al., 2011), should be assessed. Furthermore, subsequent impacts, like avoided greenhouse gas and air pollutant emissions that may have a positive benefit on public health and therefore reduce healthcare costs (Haines et al., 2009), can also be considered. However, there are methodological challenges in estimating these costs and benefits (Haines et al., 2009). Further analysis is recommended for the evaluation of these ancillary benefits in more comprehensive studies of the impacts of RES on regional economies.

In conclusion, if the aspects which are stressed in this guideline are taken into account in future publications, it will strengthen the significance of impact assessment analyses and may lead to a more considerable appreciation of the opportunities of RE deployment in regions by politics, economy, and society. 


\section{Acknowledgements}

The author gratefully acknowledges support from the FONA (Research for Sustainable Development) programme funded by the German Federal Ministry of Education and Research (BMBF) (FKZ 033L116G). I am also grateful to the Prognos AG for the permission to reproduce Figure 2.4 which is originally illustrated in Böhmer et al. (2015) (cf. References), and to the UK Department of Energy \& Climate Change for the permission to reproduce Figure 2.5 which is originally illustrated in the DTI (2004) report (cf. References). 
Assessing the Regional Economic Impacts of Renewable Energy 



\section{Regional Economic and Environmental Impacts of Renewable Energy Developments: Solar PV in the Aachen Region}

This chapter is based on the publication: Jenniches S, Worrell, E. Regional economic and environmental impacts of renewable energy developments:

Solar PV in the Aachen Region. Energy for Sustainable Development 2019;48:11-24.

https://doi.org/10.1016/j.esd.2018.10.004. 


\section{Abstract}

The energy transition is a challenge that affects regions on various scales. This paper presents the economic chances of deploying the renewable energy technology solar photovoltaic in a German region. Total regional economic effects of 280 PV plants, installed in 2014 with a cumulative capacity of $3.7 \mathrm{MW}$, lead to a regional value added of approximately $€ 3.8$ million ( $€ 1,019 / \mathrm{kW}$ installed, $€ 57 / \mathrm{MWh}$ electricity generated) and employment effects of 42 full-time person years (11 person years/MW installed), occurring from 2014 to 2034. The avoided greenhouse gas emissions of these plants are 2,365 tons $\mathrm{CO}_{2}$-equivalents per year $\left(0.7 \mathrm{kgCO}_{2}\right.$-eq/ $\mathrm{kWh}$ generated) and the avoided air pollution is $0.97 \mathrm{tSO}_{2}$ per year, $1.48 \mathrm{tNO}_{\mathrm{x}}$ per year, and $0.07 \mathrm{t}$ NMVOCs per year in 2014. The total economic effects of regional value added, avoided $\mathrm{CO}_{2}$ emissions, and avoided air pollution per year in 2014 range from $€ 0.8-1$ million or ( $€ 208-277$ per kW installed, €231-307 per MWh electricity generated). 


\subsection{Introduction}

One of the main characteristics of the German Energiewende is the transformation of the energy system from large centralised energy generation systems, based on e.g. fossil or nuclear energy, to a more distributed, decentralised energy system, based on renewable energy sources (RES) like e.g. wind or photovoltaic (PV) generated locally (Gailing and Röhring, 2015; Beckmann et al., 2013). On a spatial scale, this leads to changes in the spatial arrangement of energy systems and regions, which were previously not actively involved in energy generation may benefit economically from renewable energies. The brut electricity generation in the German Land Thuringia for example increased from 2.2 gigawatt-hours (GWh) with a share of renewable energies of 4\% in 1991 to 8.4 GWh in 2014 with a share of renewables of 55\% (LAK, s.a.). On the other hand there is still a strong, socioeconomic significance of fossil energy systems in some regions, and a skeptical view on renewable energy (RE) developments as illustrated by Keppler (2008) for the Lausitz lignite mining area. To overcome the intense sociocultural significance of economic activities related to fossil fuels in a region which may lead to lock-in effects and hinder the application of new technologies (Unruh, 2000; Grabher, 1993) in regions, positive aspects of RE developments like ecologic and economic effects should be demonstrated to increase acceptance of RE (BMVBS, 2013).

This acceptance is needed because decision-making processes on the development of renewable energy projects are not always national but rather regional issues, as shown by Jacobsson and Bergek (2004) for Dutch wind power developments. Decision power depends upon the legislative responsibilities of different governmental levels in a country. In Germany, decision-making power lays to a large extent on the regional or local level (ARL, s.a.), which is also the case in other countries (e.g. Austria (Stix, 2014) or the US (Kayden, 2000)).

In the analysis, the focus lies on PV-systems, which is a technology where the dynamics in the global renewable energy market are particularly visible. In recent years a spatial reorganisation of the PV industry, leading to job losses in the German PV manufacturing industry takes place (Wirth, 2017). Furthermore, decreasing feed-in tariffs for generated PV electricity lead to the impression that PV systems were not profitable for operators (Taunus Zeitung, 2012; Bröcker et al., 2014).

Conclusively, there is a need to show the benefits of PV developments for a region, even after market changes in terms of losses in the manufacturing industry and decreasing feed-in tariffs. 
The benefits of PV developments are evaluated in the district of Aachen (Section 3.2), as an exemplary region which is supposed to suffer in the future, due to expectable economic losses in conventional energy generation industries, illustrating that investing in renewable energies is a beneficial strategy (Section 3.3). Additionally, the environmental and economic benefits of avoided emissions due to PV developments are illustrated (Section 3.4).

\subsection{Characteristics of the region and PV developments in the region}

The district of Aachen (German: Städteregion Aachen) is located in the West of Germany in the Land North Rhine-Westphalia (Figure 3.1). It has an area size of approximately 707 $\mathrm{km}^{2}$ and a population of 554,000 inhabitants in 2015 (IT.NRW, s.a.) and is subdivided into 10 municipalities. The region is categorised as a NUTS 3 region in the European statistical classification, which is the lowest category for regions (Eurostat, s.a.c), and is, therefore, classified as a small region on a European scale.

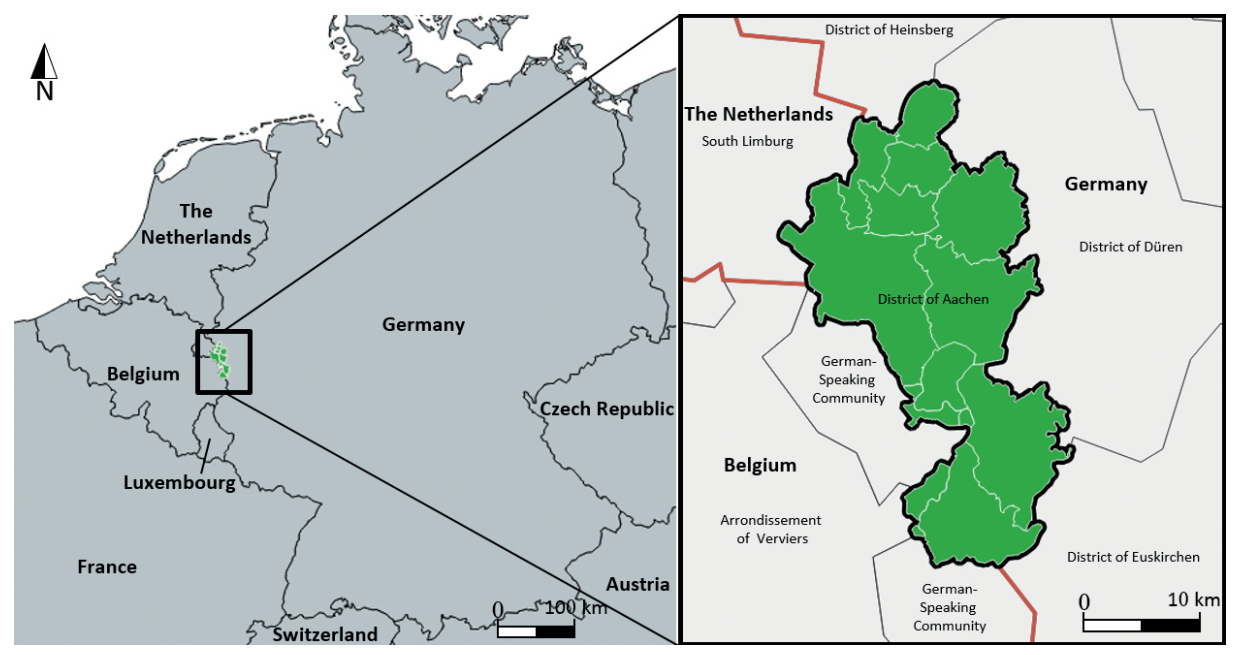

Figure 3.1: Location of the district of Aachen in Germany (left side) and neighbouring territorial units (right side) on NUTS 3 level (Source: author's own graph, map data source: Eurostat, s.a.a)

The Aachen mining region in the north of the region has been one of the oldest European black coal mining regions whose last coal mine was closed in 1997 (Bergbaumuseum Grube Anna e.V., s.a.). The lignite power plant Weisweiler, producing 15.3 terrawatt-hours (TWh) of electricity per year (mean value of electricity generation from 2012 to 2014) is located in the municipality of Eschweiler in the East of the district, as well as the open lignite mine Inden which lays partly in the district of Aachen and 
the district of Düren. It is aimed to close the lignite mine by 2030 (RWE Power AG, s.a.). In 2009, the mining and energy company RWE Power AG employed approximately 1,600 employees in the open lignite mine and the power plant Weisweiler, which demonstrates the economic significance of fossil fuels in the region (RWE Power AG, 2009).

The region may be characterised as a forerunner in the development of PV plants, because of the early implementation of cost covering feed-in tariffs for PV operators and a transfer of the costs to electricity consumers (so called Aachener Modell) in the region in the 1990s. That model was adapted by other German cities and later on by Feed-in tariffs regulations (FiT) in the German Renewable Energies Act (EEG) in 2000, which lead to large-scale PV deployment in Germany (Mertens, 2015; Willecke and Räuber, 2012; Edinger, 1999). Figure 3.2 shows the PV development since 1994 in the region (left). Until 1996, small-scale developments with 295 kilowatts (kW) of cumulative installed capacity in 1996 dominated. Since 2007, the regional market acts very dynamic with large-scale developments especially in 2011 (16.9 megawatts (MW)) and 2012 (18.7 MW). In 2014, the installed capacity of plants that have been installed since 1994 is $70.9 \mathrm{MW}$. The majority (54.4 MW) of plants are rooftop plants.

In comparison to Germany, there is a relatively high dynamic in the 1990s due to the early implementation of feed-in tariffs in the region (Figure 3.2, right). After 2000 and implementing the EEG in Germany, significantly higher dynamics in the German market take place which may be explicable by more favourable global radiation potentials in other German regions (e.g. South of Germany) which led to large-scale deployments (Agentur für Erneuerbare Energien, s.a.d). In the South German Land Bavaria for example, 29\% of all PV plants in Germany are installed (data compilation by Agentur für Erneuerbare Energien, s.a.d and BMWi, 2016), whereas it covers only $20 \%$ of the total area of Germany (Destatis, 2017). 


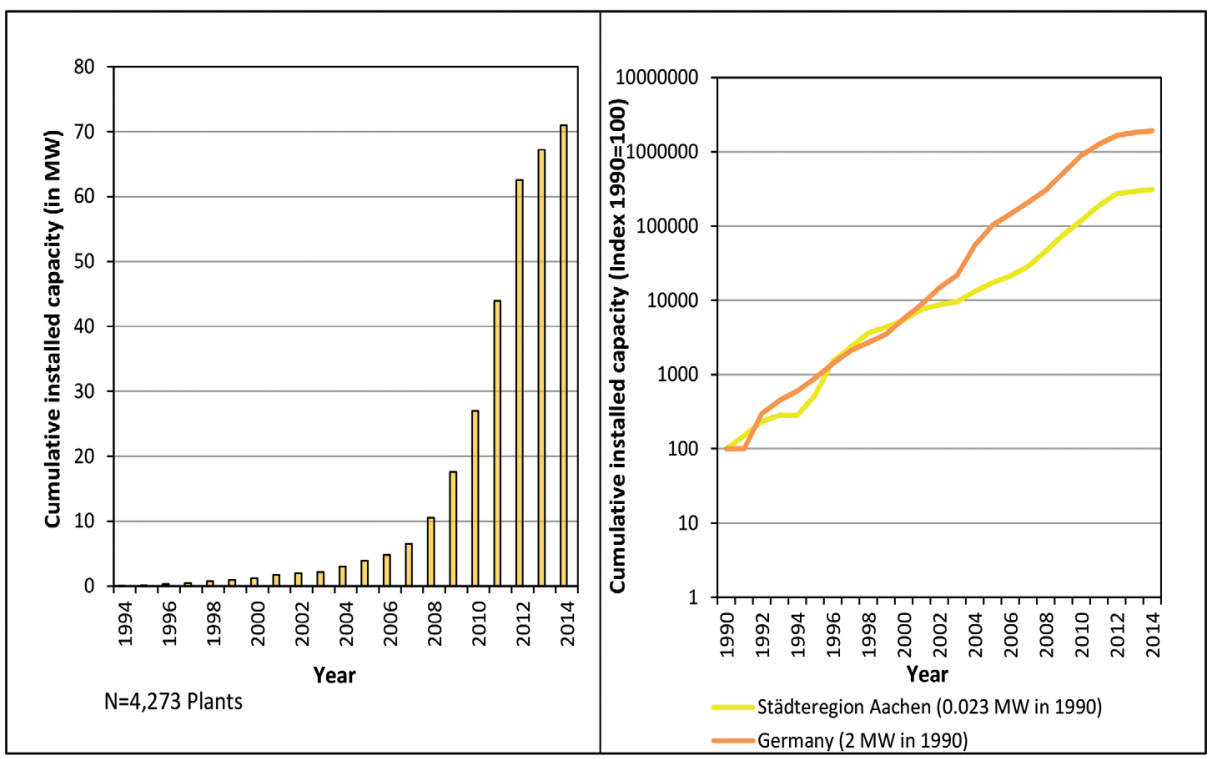

Figure 3.2: Cumulative installed capacity of PV (rooftop and open space) in the district of Aachen from 1994-2014 (left) (Source: render, 2016) and PV developments in comparison to Germany from 1990-201423 (right) (Source: data compilation by BMWi, 2016 for Germany and render, 2016 for the district of Aachen)

\subsection{Regional economic impacts of PV}

\subsubsection{Selection of an impact assessment method}

Three often applied methods can be identified to assess positive economic and employment effects of renewable energies. These are employment ratios, inputoutput (IO) models, and analyses of supply chains (Jenniches, 2018).

As it is intended to look beyond the assessment of regional employment effects only, the advantages and challenges of conducting an impact analysis based on regional IO models and supply chain analyses are solely presented in the following.

The special characteristic of $\mathrm{IO}$ models is the representation of interactions in a defined economy (e.g. a country), by illustrating the exchange of goods and services. These exchanges are captured in an overall view which ranges from production to the final

23 Due to issues of illustratability a logarithmic scale has been used, which has to be taken into account when comparing the different developments in Germany and the district of Aachen. 
use of commodities and thus includes all direct and indirect effects (Statistisches Bundesamt, 2010). A clear advantage of the approach lays in the comprehensive illustration of economic exchange.

When using $\mathrm{IO}$ tables to illustrate the economic effects of renewable energies, there are several challenges. National statistics do normally not distinguish between economic activities in the field of fossil or renewable energies like in the case of Germany where IO tables contain only electricity generation in general (Statistisches Bundesamt, 2010). Therefore, the effects of, for example, electricity generation by renewable energies have to be disaggregated in a resource binding process to illustrate the effects of RES. Original tables illustrating inputs and outputs on a regional scale (regional IO tables (RIOTs)) are not available for small regions in Germany (DIW, 2014b) and have to be derived from national data by calculations (e.g. Hirschl et al., 2015) or extensive surveys (e.g. Coon et al., 1985). However, BMVBS (2011) state a lack of precision of non-survey based IO modelling on a small regional scale. Further discussions on IO modelling is found in e.g. Richardson (1972) or Miller and Blair (2009). Studies that use RIOTs with regard to renewable energies are Coon et al. (2012), Slattery et al. (2011), or Stoddard et al. (2006).

The analysis of supply chains follows the idea of evaluating single economic activities (e.g. installation or operation) of renewable energy deployment. In the evaluation, the costs of the plant operator for the activities (e.g. maintenance) are considered as revenues of the respective companies. In a first step, the revenues are disaggregated into material costs (or intermediate inputs) provided by the suppliers and additional revenues. These additional revenues are needed to calculate the economic effects with regard to the maintenance industry by applying industry specific statistics. The material costs may be interpreted as revenues of the wholesale trade which may be disaggregated into intermediate goods and additional revenues as well. By applying industry specific statistics, the economic effects of the trade are evaluated. The intermediate goods are interpreted as revenues of component manufacturers and so on. A clear advantage of this bottom-up method is that effects of individual activities can be determined very precisely. In a supply chain analysis, a precise distinction between renewable energy technologies and even regarding a particular technology (e.g. between small and large power plants) should be made (Böhmer et al., 2015).

A challenge is the accuracy and the quantity of information on costs that is needed to perform a supply chain analysis. Moreover, a realistic estimation of activities that can be taken over by regional companies (Section 3.3.2.1) may be quite resource demanding because the renewable energy industry is inadequately captured in official 
statistics (Section 3.3.2). Examples of supply chain analyses are Hirschl et al. (2015) or Finus et al. (2013).

For the analysis of the district of Aachen, a supply chain analysis has been identified as the most favourable assessment approach, because original IO tables for small regions are not available and a survey based approach was considered as being too resource intensive. Moreover, according to Llera-Sastresa et al. (2010), "analytical models" (Llera-Sastresa et al., 2010:680) like the supply chain approach are considered as being more transparent in comparison to IO tables, because the weight of specific variables influencing the results can be more easily assessed.

\subsubsection{Assessing the regional economic impact of PV}

Concerning the components and the assessment of local or regional value added, the paper follows Hirschl et al. (2010) and Bröcker et al. (2014) who define them as profits of enterprises, net income of employees of enterprises, and locally or regionally raised taxes. ${ }^{24}$ Employment effects are evaluated in full-time employment personyears. These key figures cover most of the impacts that have been analysed in previous regional economic impact assessment studies of renewable energies (Jenniches, 2018). ${ }^{25}$

In this section, the impacts are calculated for the latest available data of plants that is 2014. The conducted supply analysis does not include an overall assessment of the PV industry in a region, but enables a quantification of the impacts directly induced by the deployment of PV in the region. Therefore, the additional impacts of the PV industry are estimated by relying on industry statistics.

The assessment is structured as follows: After a lifecycle analysis, where activities in the PV lifecycle are evaluated, local shares of the specific activities are defined (Section 3.3.2.1). This section also includes the evaluation about the economic benefits of the PV industry in general which are not dependent on regional PV developments only. In a further step, a cost analysis is conducted (Section 3.3.2.2). The costs of different activities may be interpreted as revenues of regional enterprises (e.g. planning or

24 All taxes which are not raised by the municipalities in the region are not taken into account as a component of the regional value added. Subsidies are not taken into account.

25 By applying the supply chain approach, the gross effects of PV developments are studied. Net effects as a result of crowding out other electricity generation technologies are neglected in the calculation model and, therefore, an estimation of the potential effects on the lignite industry is additionally provided by a separate analysis (Section 3.3.3). 
installation companies), that are needed to analyse the economic effects in the following part of the section (Section 3.3.2.3). Finally, the assessment of the activity electricity generation (Section 3.3.2.4) is demonstrated.

\subsubsection{Lifecycle analysis and estimation of economic activities carried out in the region}

Illustrating the lifecycle of PV plants, the paper follows Llera et al. (2013) who define five lifecycle stages of renewable energy plants. In the following, it is referred to these lifecycle stages as research and development (R\&D) (1), manufacturing (2), installation (3), operation and maintenance (O\&M) (4), and decommissioning (5).

As a first step, the stages of the PV plant lifecycle regarding their specific activities are analysed. These activities have been derived from existing studies in the field such as BMVBS (2011), Hirschl et al. (2010), and PV information platforms like Heindl Server $\mathrm{GmbH}$ (s.a.). Evaluating the activities in the PV supply chain that are carried out by regional enterprises is challenging as the renewable energy industry is insufficiently listed in official statistics. Different industry statistics from official and non-official sources such as IHK Aachen (s.a.a), Heindl Server GmbH (s.a.), Cylex International S.N.C. (s.a.) have, therefore, been used to identify individual potential enterprises in the renewable energy market in 2015 by hand. In an extensive analysis, which was supported by an online survey, 225 enterprises that were able to be active in the PV market have been identified. This excludes insurance companies, tax advisory enterprises, or financial institutes that are active in the market and located in the region.

For R\&D there are methodological obstacles to calculate a realistic and quantifiable economic impact of organisations in the region regarding regional PV developments, because of international cooperation in R\&D activities (de Paolo et al., 2016; Quitzow, 2015), and as it is hard to define an economic value for R\&D activities in the price of a plant component, which is essential for the assessed supply chain approach. In the Aachen region, three enterprises and one institute of RWTH Aachen University, involved in PV related R\&D activities have been identified. According to Bundesanzeiger Verlag GmbH (s.a.), profits of the three enterprises have been $€ 856,000$ in 2014 and the institute employed 16 employees. This value can be serve as a broad estimation since it could not be identified how much of these profits and employment effects are accountable for solely PV related activities. 
Although PV related manufacturers are located in the region it is difficult to define a realistic share of components of PV plants in the region, originating from these manufacturers, because the production capacities as well as the delivering flows of regional manufacturers are unknown and could only be estimated very broadly. That challenge is also stated by Kirkegaard et al. (2010). Eight component manufacturers, have been identified in the region. Profits of PV related manufacturing enterprises have been calculated by relying on data of Bundesanzeiger Verlag $\mathrm{GmbH}$ (s.a.) and are approximately $€ 1,678,000$ (in 2014 and for one enterprise in 2013). ${ }^{26}$ As in the case of R\&D, these profits are not only generated by PV related activities and illustrate the situation in 2014. Like for $R \& D$ related activities, these profits are decoupled from the supply chain analysis because they are generated from PV developments inside and outside the region.

As an overall trend in R\&D and manufacturing, a rising importance of actors from Asian countries can be observed (Binz et al., 2017a for R\&D and Quitzow, 2015 for manufacturing). Therefore, it is beneficial from a regional economic development perspective to refer to other parts of the lifecycle stage, which can be done by organisations from the region in the long term. Hence, the focus of the supply chain analysis lies on the stages installation, O\&M, and decommissioning (Figure 3.3), where an allocation of activities, done by regional enterprises concerning regionally installed plants is more probable (Llera et al., 2013).

The local shares for installation, O\&M, and decommissioning have been estimated based on the regional industry analysis and assumptions from existing studies. A local share of $100 \%$ has been assumed for all activities, excluding grid connection, metering, funding, and insurance. For grid connection and metering, a regional share of $93 \%$ has been estimated, based on the distribution of grid operators of the PV plant stock in the region that started operating between 1994 and 2014 (render, 2016). The regional share of financial institutions (45\%) has been estimated following BMBVS (2011). Given the fact that insurance contracts may be taken out by online insurances or a local insurance broker a share of $50 \%$ of insurance contracts between the operator and a regional insurance broker has been assumed.

26 In this number, the profits of two manufacturing enterprises are not included, because they were subsidiaries and it is not possible to estimate the share of profits which is generated by them. Moreover, the profits of two manufacturing enterprises $(€ 835,000)$ have already been included in the $R \& D$ enterprises' profits because they are also involved in $R \& D$ related activities. 


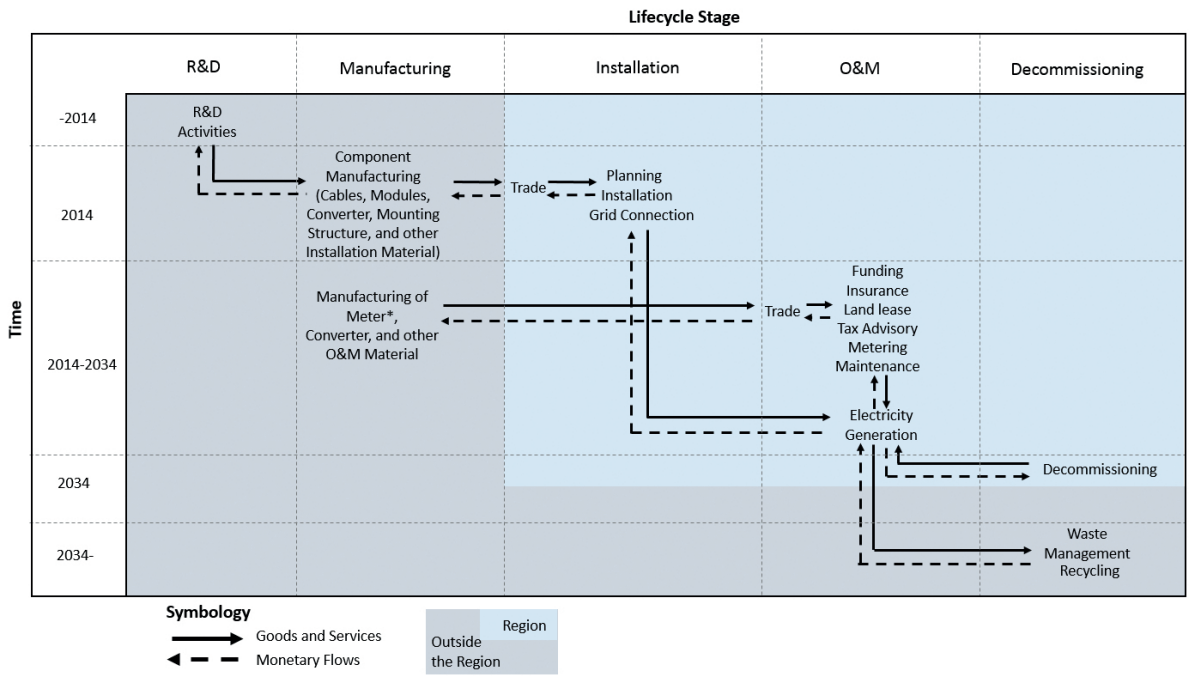

Figure 3.3: Activities, flows, spatial scope, and temporal dimension of different lifecycle stages of PV systems, installed in the district of Aachen in 2014 ( ${ }^{*}$ meter manufacturing is supposed to happen in 2014 whereas the meter lease happens from 2014 to 2034)

The effects of PV plants, which have been installed in the region in 2014 are evaluated. $R \& D$ of the PV technology has been conducted before the component manufacturing stage that may take place in $\mathbf{2 0 1 4}$ or before. After the installation and grid connection in 2014, a plant operation period of 20 years (2014-2034), as assumed by Bröcker et al. (2014), Hirschl et al. (2010), and other authors is assumed, although plants may operate longer (Wirth, 2014). Decommissioning takes therefore place in 2034. As depicted in Figure 3.3, a flow of goods and services takes place starting from manufacturers, to the wholesale trade, to service providers, and finally to the plant operator. In the opposite direction a flow of monetary transactions occurs that is evaluated in the cost analysis. In the following, a cost analysis is carried out, which is needed to calculate the regional economic effects (Section 3.3.23 and 3.3.24) occurring in every activity listed in Figure 3.3. 
Chapter 3

Table 3.1: Estimated costs in specific lifecycle stages for rooftop PV plants by power classes installed in 2014 (nominal values) ${ }^{27}, 28$

\begin{tabular}{|c|c|c|c|c|}
\hline \multirow{2}{*}{ Lifecycle Stage } & \multirow{2}{*}{ Activity } & \multicolumn{3}{|c|}{ Power Class } \\
\hline & & $<10 \mathrm{~kW}$ & $10<100 \mathrm{~kW}$ & $>=100 \mathrm{~kW}$ \\
\hline \multirow{9}{*}{ Installation } & Planning & $€ 208 / \mathrm{kW}$ & $€ 170 / \mathrm{kW}$ & $€ 47 / \mathrm{kW}$ \\
\hline & Cabling & $€ 70 / \mathrm{kW}$ & $€ 68 / \mathrm{kW}$ & $€ 64 / \mathrm{kW}$ \\
\hline & $\begin{array}{l}\text { Grid connection } \\
\text { (material costs) }\end{array}$ & $€ 119 / \mathrm{kW}$ & $€ 17 / \mathrm{kW}^{29}$ & $€ 56 / \mathrm{kW}$ \\
\hline & $\begin{array}{l}\text { Grid connection } \\
\text { (labour costs) }\end{array}$ & $€ 51 / \mathrm{kW}$ & $€ 7 / \mathrm{kW}^{29}$ & $€ 24 / \mathrm{kW}$ \\
\hline & Mounting structure & $€ 160 / \mathrm{kW}$ & $€ 155 / \mathrm{kW}$ & $€ 145 / \mathrm{kW}$ \\
\hline & Installation & $€ 176 / \mathrm{kW}$ & $€ 147 / \mathrm{kW}$ & $€ 103 / \mathrm{kW}$ \\
\hline & Inverter & $€ 176 / k W$ & $€ 144 / \mathrm{kW}$ & $€ 130 / \mathrm{kW}$ \\
\hline & Modules & $€ 624 / k W$ & $€ 603 / \mathrm{kW}$ & $€ 566 / \mathrm{kW}$ \\
\hline & Installation total & $€ 1584 / \mathrm{kW}$ & $€ 1310 / \mathrm{kW}$ & $€ 1134 / \mathrm{kW}$ \\
\hline
\end{tabular}

27 For plants with a capacity above $100 \mathrm{~kW}$, additional costs for management, leasing costs of the roof, etc. have to be considered. The assumed share of borrowed capital for plants with a capacity below 10 kW is 50\% (Hirschl et al., 2010), between 10 and 100 kW 63\%, and above $100 \mathrm{~kW} \mathrm{75 \%} \mathrm{(Kelm} \mathrm{et} \mathrm{al.,} \mathrm{2014).}$ For funding, an effective interest rate of $3 \%$ for a credit period of 20 years is assumed (KfW, 2015). The decommissioning stage includes the end-of-life activity uninstallation only. Because future material costs of the plant (e.g. mounting structure) exceed the decommissioning costs (Janzing, 2015) they are cost neutral to the plant operator.

28 (Sources: Installation costs: Kelm et al., 2014 and own calculations based on Reichmuth et al., 2011 for cables, grid connection and substructure; Operation costs: own calculations based on Schormann und Behrla, s.a. (maintenance), Christian Münch GmbH, s.a. (meter lease), Eggers s.a., (insurance), BMVBS, 2011 (tax advisory services), Hirschl et al., 2010 (management and liability renumeration); Decommissioning costs: Kelm et al. ,2014 and own calculations based on Reichmuth et al., 2011 (operation excluding funding costs))

29 Total grid connection costs are $€ 1,700$ minimum 
Table 3.1: Estimated costs in specific lifecycle stages for rooftop PV plants by power classes installed in 2014 (nominal values) (continued)

\begin{tabular}{|c|c|c|c|c|}
\hline \multirow{2}{*}{ Lifecycle Stage } & \multirow{2}{*}{ Activity } & \multicolumn{3}{|c|}{ Power Class } \\
\hline & & $<10 \mathrm{~kW}$ & $10<100 \mathrm{~kW}$ & $>=100 \mathrm{~kW}$ \\
\hline \multirow{8}{*}{ Operation } & Maintenance & $€ 20 / \mathrm{kW} / \mathrm{a}$ & $€ 20 / \mathrm{kW} / \mathrm{a}$ & $€ 20 / \mathrm{kW} / \mathrm{a}$ \\
\hline & Meter lease & $€ 40 / a$ & $€ 40 / a$ & $€ 40 / a$ \\
\hline & Insurance & $€ 100 / a$ & $\begin{array}{c}€ 25 / \mathrm{a}+ \\
€ 2.5 / \mathrm{kW} / \mathrm{a}^{30}\end{array}$ & $\begin{array}{c}€ 25 / \mathrm{a}+ \\
€ 2.5 / \mathrm{kW} / \mathrm{a}\end{array}$ \\
\hline & Tax advisory & - & - & $\begin{array}{c}€ 3.9 / \mathrm{a}+ \\
€ 4.1 / \mathrm{kW} / \mathrm{a}\end{array}$ \\
\hline & $\begin{array}{l}\text { Liability } \\
\text { renumeration }\end{array}$ & - & - & $€ 1 / \mathrm{kW} / \mathrm{a}$ \\
\hline & Management & - & - & $€ 13 / \mathrm{kW} / \mathrm{a}$ \\
\hline & Roof lease & - & - & $€ 33 / \mathrm{kW} / \mathrm{a}$ \\
\hline & Operation total & $\begin{array}{c}(€ 140+ \\
€ 20 / \mathrm{kW}) / \mathrm{a}\end{array}$ & $\begin{array}{c}(€ 65+ \\
€ 23 / \mathrm{kW}) / \mathrm{a}\end{array}$ & $\begin{array}{c}(€ 69+ \\
€ 74 / \mathrm{kW}) / \mathrm{a}\end{array}$ \\
\hline Decommissioning & Decommissioning & $€ 176 / \mathrm{kW}$ & $€ 147 / \mathrm{kW}$ & $€ 103 / \mathrm{kW}$ \\
\hline
\end{tabular}

\subsubsection{Cost analysis of PV systems}

The starting point of assessing the effects that arise in the lifecycle stages of PV plants are the costs for the plant operator (see Table 3.1).

For the assessment, data should be highly disaggregated, i.e. every component and activity for different plant sizes with specific costs should be assessed (Table 3.1).

\subsubsection{Effects during installation, operation, and decommissioning}

The total number of plants installed in the region in 2014 is 280 plants with a total cumulative capacity of 3,724 kW (Figure 3.4). 227 plants with a capacity below $10 \mathrm{~kW}$ and with a cumulative capacity of $1,354 \mathrm{~kW}, 45$ plants with a capacity ranging from 10-100 kW with a total capacity of 1,208 kW, and 8 plants with a capacity above 100 $\mathrm{kW}$ with a total capacity of 1,162 kW, have been installed. 


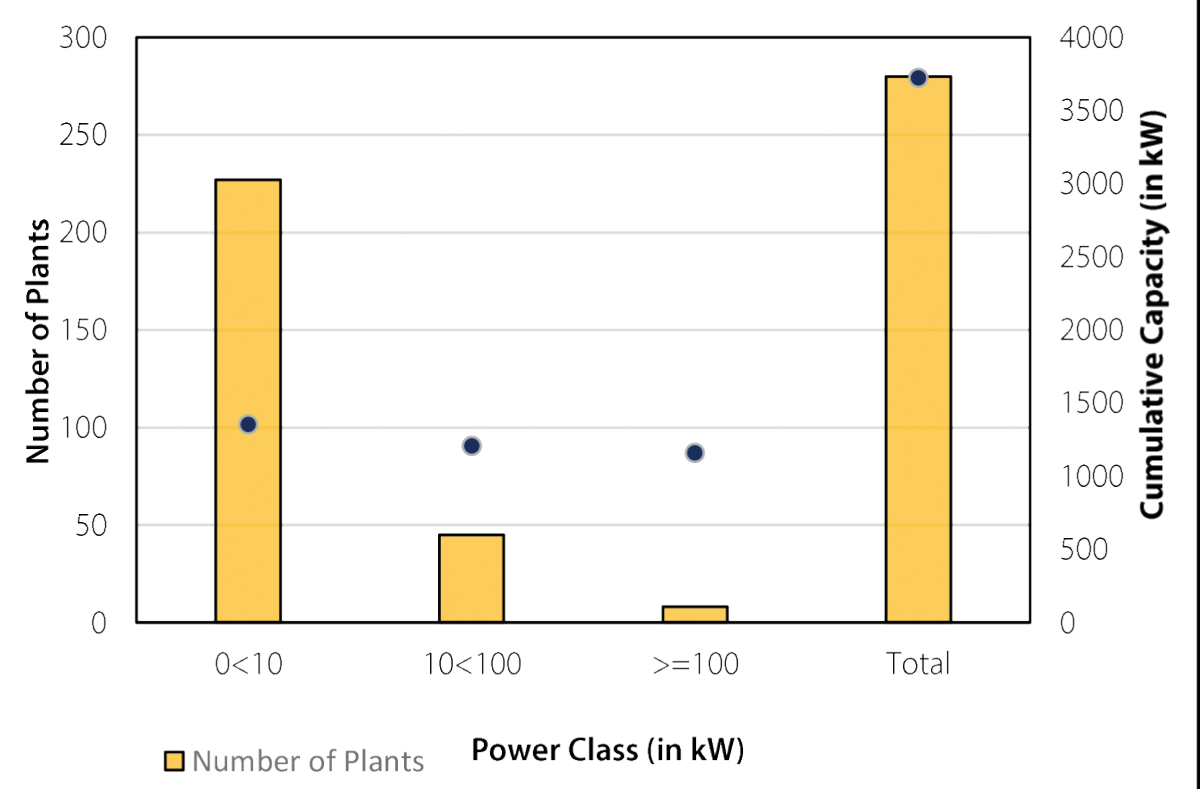

Figure 3.4: Number of plants and total installed capacity of plants installed in 2014 in the district of Aachen (Source: own calculations based on render, 2016)

Regarding the electricity generated by these plants, 900 full load hours that is a mean value for the Land North Rhine-Westphalia (LANUV, 2016) are used, since specific data for the region is not available. That value may be interpreted as a conservative assumption for the region, because natural conditions in the Aachen region are rather favourable in comparison to most parts of the Land (LANUV, 2013). By multiplying the installed capacity with the full load hours and the years of operation, the total electricity generated between 2014 and 2034 is 67,032 MWh.

After the cost analysis (Section 3.3.2.2) the regional economic impacts of the plants that have been installed in 2014 are calculated. As a precondition, costs for plant operators (Table 3.1) are interpreted as the revenues of suppliers. Figure 3.5 depicts the calculation of economic effects (i.e. enterprise profits, net income, and municipal taxes) for the assembly of all plants with a capacity below $10 \mathrm{~kW}$. 
Regional Economic and Environmental Impacts of Renewable Energy Developments: PV

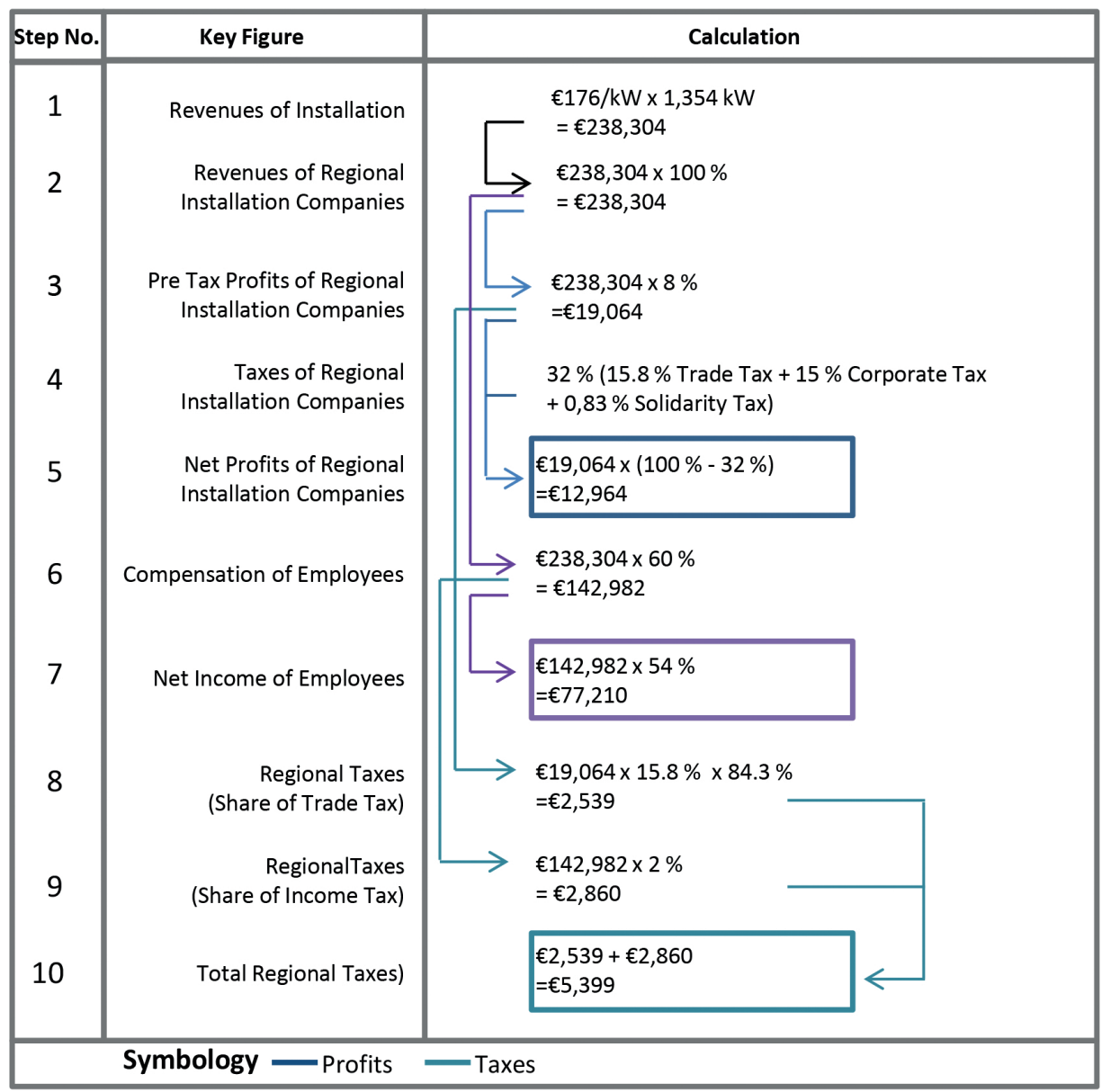

Figure 3.5: Calculation of profits, income, and taxes regarding the installation of rooftop PV plants with a capacity below $10 \mathrm{~kW}$ installed in 2014 in the district of Aachen (nominal values)

First, the revenues (1) and the regional share of enterprises (Section 3.3.2.1) are used to calculate the regional revenues (2) (Section 3.3.2.2). Next, industry specific values have been used to calculate the benefits of enterprises before taxes (3). These values have been derived from Deutsche Bundesbank (s.a.a) for financial institutions and Deutsche Bundesbank (s.a.b) for the other industries, by using a mean value of various years.

For enterprise taxes, national standardised taxes (corporate tax and solidarity $\operatorname{tax}^{31}$ ) (4) depending on the legal form of the enterprise are included. That was derived from the

31 The solidarity tax is a tax that has been introduced in the 1990s to finance the German reunification (Bundesministerium der Finanzen, s.a.a). 
analysis of legal forms of local PV businesses, and locally different shares of trade taxes based on IT.NRW (2015). By subtracting the taxes from the enterprise revenues, the net profits of enterprises (5) are assessed. To assess the compensation of employees, industry specific values have been used (6).

For the employees' taxes and charges (e.g. for health insurance) (7), income specific tax shares based on Bundesministerium der Finanzen (2016) have been used. Municipalities benefit from taxes so that a part of trade taxes (8) and a part of income taxes (9) are allocated by the municipality (10) (Bundesministerium der Finanzen, s.a.b). These calculations have been conducted for every activity and every power class of installed plants.

\subsubsection{Calculation of effects during electricity generation}

For electricity generation of PV plants in Germany, profits of plant operators have usually been calculated by multiplying the electricity generated with feed-in tariffs that are regularly published by the German Federal Network Agency (Bundesnetzagentur, 2017a), which is also the case in comparable regional impacts studies like BMVBS (2011) or Bröcker et al. (2014).

The feed-in tariffs depend on the capacity of a plant and the larger the capacity, the smaller the fee in c/kWh for electricity fed in the grid is provided. Equation 3.1 illustrates the calculation of the feed-in tariff for a $40 \mathrm{~kW}$ rooftop PV plant that is paid for 20 years of operation.

75\% (share of capacity below $30 \mathrm{~kW}$ ) x 34.05c/kWh (feed-in tariff for a plant capacity below $30 \mathrm{~kW}$ ) + 25\% (share of capacity ranging from 30-100 kW) x $32.39 \mathrm{c} / \mathrm{kWh}$ (feed-in tariff ranging from 30-100 kW) = 33.64 c/kWh

Equation 3.1: Feed-in tariff of a 40 kW PV plant that starts operating in July 2010 (Source: Clearingstelle EEG, s.a., modified)

Feed-in tariffs also depend on PV deployment in Germany over time. Tariffs decrease if the PV development path, determined by the Renewable Energy Act (EEG), is exceeded and increases if the installed capacity falls below.

Since 2012, feed-in tariffs for plants with a capacity below $30 \mathrm{~kW}(€ 0.24 / \mathrm{kWh}$ start of operation from January to March 2012, Clearingstelle EEG, s.a.) are lower than 
electricity prices for consumers with an annual consumption between 2,500 kWh and $5,000 \mathrm{kWh}(€ 0.26 / \mathrm{kWh}$ in the first half of the year, Eurostat, 2015) that is a characteristic consumption for private households. Therefore, it is economically more efficient for plant operators to consume generated electricity and minimise overproduction, rather than to feed it into the grid and benefit from the feed-in tariff, especially since feedin tariffs decreased further. The feed-in tariff for a plant with a capacity below $10 \mathrm{~kW}$ starting to operate in January 2014 for example is $€ 0.14 / \mathrm{kWh}$ (Clearingstelle EEG, s.a.). Therefore, PV operators do become so-called prosumers who produce and consume electricity (IEA-RETD, 2014).

The amount of generated electricity that can be consumed depends on several factors such as load management and consumer behaviour (von Bost et al., 2011). Storage systems, which also positively affect internal consumption of generated electricity, are disregarded because they are not sufficiently economically deployable in 2014 in most cases (Leipziger Institut für Energie, 2014). However, they should be taken into account in forthcoming studies, because of decreasing system prices (Sterner et al., 2015).

Kelm (2015) estimates potential internal consumption of PV plants of different power classes (Table 3.2). These may be higher or lower due to specific consumption patterns in individual cases, such as stated by SMA (2013) for non-private consumers, but provide an indication.

Table 3.2: Building typologies and internal consumption of typical PV power classes

\begin{tabular}{lll}
\hline Power Class & Building Type & Internal Consumption \\
\hline$<\mathbf{1 0} \mathbf{~ k W}$ & detached and semi-detached homes & $\approx 30 \%$ on average \\
$\mathbf{1 0 - 4 0 ~ k W}$ & $\begin{array}{l}\text { apartment buildings, barns, } \\
\text { stables, small businesses, small administration } \\
\text { buildings, schools }\end{array}$ & $\approx 40 \%$ on average \\
$\mathbf{4 0 - 1 0 0 ~} \mathbf{~ W W}$ & $\begin{array}{l}\text { large apartment buildings, barns, stables, } \\
\text { schools, administration buildings, trade } \\
\text { buildings }\end{array}$ & $\approx 40 \%$ on average \\
$\mathbf{1 0 0 - 1 , 0 0 0 ~} \mathbf{~ k W}$ & $\begin{array}{l}\text { large farming buildings, } \\
\text { large supermarkets, factory buildings }\end{array}$ & $\approx 40 \%$ on average \\
\hline
\end{tabular}

(Source: Kelm 2015, modified) 
Following Kelm (2015), an amount of energy that is fed into the grid of 70\% for rooftop plants with a capacity below $10 \mathrm{~kW}$ and of $60 \%$ for larger plants is estimated. The profitability of plants depends on the development of future electricity prices. To estimate future prices in Germany, the paper follows an energy market prognosis conducted by Schlesinger et al. (2014) (see Figure 3.6).

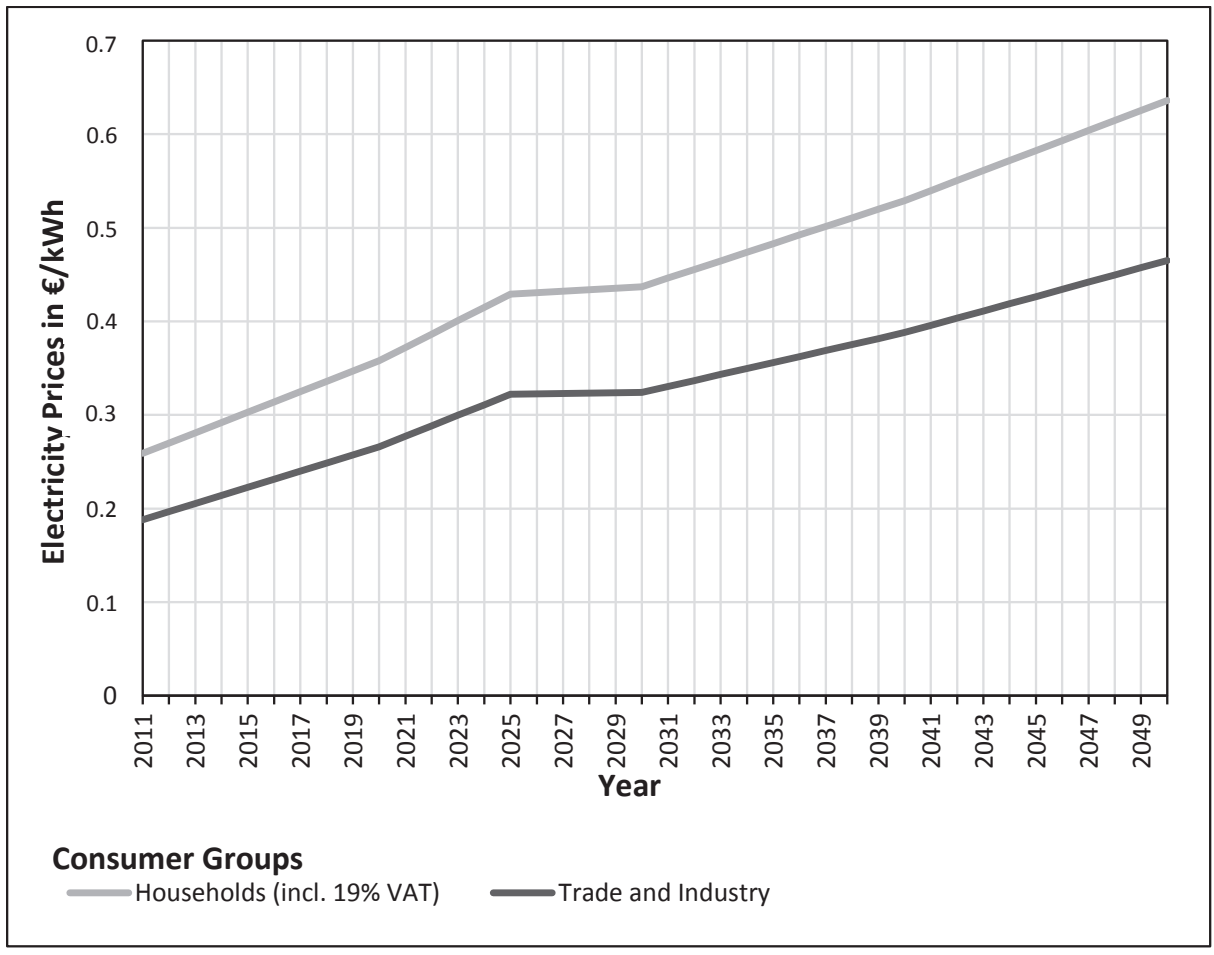

Figure 3.6: Development of annual electricity prices in $€ / \mathrm{kWh}$ (nominal values) for households (including value added tax), trade and industry (excluding manufacturing and energy intensive industries) (Source: Schlesinger et al. 2014, modified)

Following the building types in Table 3.2 and the derived consumer groups, the household electricity prices have been used as a reference to calculate the avoided electricity costs for plants with a capacity below $10 \mathrm{~kW}$ and the trade and industry prices as a reference for larger plants.

Since the introduction of the EEG 2014 in August 2014, the consumption of PV electricity is charged with a fee per kWh from consumers, except for plants with a capacity below $10 \mathrm{~kW}$ and an annual internal consumption below $10 \mathrm{MWh}$. The annual charge is estimated by following Schlesinger et al. (2014). A reduction of the charge 
may be granted if the operator and the consumer of the plant is the same person (Bundesnetzagentur, 2016), which is integrated by following Bundesministerium der Justiz und für Verbraucherschutz (s.a.a).

The assessment of economic impacts for electricity generation is exemplified by a 80 kW PV plant in the following Figure 3.7, which leads to revenues of $€ 59,000$ for the plant operator and municipal taxes of $€ 7,000 .{ }^{32}$

\begin{tabular}{|c|c|c|}
\hline Step No. & Key Figure & Calculation \\
\hline 1 & Electricity Generation & $\begin{array}{l}80 \mathrm{~kW} \times 900 \mathrm{~h} \times 20 \mathrm{a} \\
-=1,440,000 \mathrm{kWh}\end{array}$ \\
\hline 2 & + Revenue Feed-in-Tariff & $\begin{array}{l}\rightarrow 1,440,000 \mathrm{kWh} \times € 0.1164 / \mathrm{kWh} \times 60 \% \\
\quad=€ 100,570\end{array}$ \\
\hline 3 & $\begin{array}{r}\text { Revenue Avoided } \\
\text { Electricity Costs }\end{array}$ & $\begin{aligned} \rightarrow & 1,440,000 \mathrm{kWh} \times € 0.29 / \mathrm{kWh} \times 40 \% \\
& =€ 167,040\end{aligned}$ \\
\hline 4 & Installation Costs & $\begin{array}{l}80 \mathrm{~kW} x € 1,274 / \mathrm{kW} \\
=€ 101,920\end{array}$ \\
\hline 5 & Operation Costs & $\begin{array}{l}\text { (€65+€23/kW } \times 80 \mathrm{~kW}) \times 20 \text { a } \\
=€ 38,100+€ 21,932 \text { (Funding Costs) }\end{array}$ \\
\hline 6 & Revenues & $€ 105,658$ \\
\hline 7 & Income Taxes & $\begin{aligned} & € 105,658 \times 42 \% \\
& =€ 44,376\end{aligned}$ \\
\hline 8 & Solidarity Tax & $\begin{aligned} & € 44,376 \times 5.5 \% \\
& =€ 2,441\end{aligned}$ \\
\hline 9 & $=$ Revenues after Taxes & $\longrightarrow € 58,841$ \\
\hline 10 & Municipal Taxes & $\begin{array}{l}€ 44,376 \times 15 \% \\
=€ 6,656\end{array}$ \\
\hline
\end{tabular}

Figure 3.7: Regional economic impacts of electricity generation of an $80 \mathrm{~kW}$ PV plant, installed in July 2014 in the district of Aachen (nominal values)

32 Due to individual revenues (e.g. the feed-in tariff depends on the date when the individual plant starts operating), calculations cannot be illustrated aggregated for a market segment as in the case of the activity installation (Figure 3.5) and have been conducted for every single plant that has been installed in the region in 2014 individually. 


\subsubsection{Results}

Table 3.3 depicts the regional value added and employment effects of plants installed in 2014. The lifecycle stages are illustrated by different frames representing installation, operation, and decommissioning.

These are the results of the calculation of the total regional value added of every economic activity with regional enterprises involved (Figure 3.3) as demonstrated in Figure 3.5 for the activity installation of plants with capacities below $10 \mathrm{~kW}^{33}$ and in Figure 3.7 for an individual plant for the activity electricity generation, which is included in the aggregated result of electricity generation of plants with capacities between 10 and $100 \mathrm{~kW}$.

Overall economic effects equate to $€ 3,796,000$ consisting of the components profits $(€ 2,334,000)$, net income $(€ 1,151,000)$, and taxes $(€ 311,000)$. Most of the effects occur during operation between 2014 and 2034 with total effects equating to $€ 2,999,000$ ( $€ 0.03 / \mathrm{kWh}$ for electricity generation and $€ 302 / \mathrm{kW}$ for operation excluding electricity generation), followed by the effects during installation $(€ 579,000)(€ 156 / \mathrm{kW}$ installed) and decommissioning $(€ 217,000)(€ 58 / \mathrm{kW}$ decommissioned). The rather large proportion of effects during the operation depends strongly upon the effects of electricity generation that contribute to $62 \%$ of the effects during operation.

The highest share of effects is attributable to electricity generation with approximately $€ 1,874,000$, or $49 \%$ of total effects, of PV plants installed in 2014. Concerning the PV installation industry, total effects of $€ 774,000$ are generated, which represent the second highest share of effects regarding the industries. Approximately half of these effects $(€ 339,000)$ arise during the operation stage. The other effects occur in 2014 during installation and 2034 during decommissioning of PV plants. Effects arising concerning land (i.e. roof) lease represent the third highest share with $€ 512,000$, where $€ 222.000$ of the effects occur regarding private and $€ 290.000$ concerning public landlords. Other effects are between $€ 200,000$ and $€ 100,000$ except those regarding tax advisory and insurance services that are lower.

Employments effects are 16 full-time jobs in 2014 (4 full-time jobs/MW installed), 20 person-years between 2014 and 2034 ( 0.06 person-years/GWh electricity generation and 4.3 person-years/MW for operation excluding electricity generation) (which is equal to one full-time job per year), and 7 full-time jobs (1.9 full-time jobs/MW installed) in 2034. Total employment effects are therefore 42 person-years. 
Regional Economic and Environmental Impacts of Renewable Energy Developments: PV

Table 3.3: Detailed overview about total regional value added and employment effects of PV plants installed in 2014 in the district of Aachen (in $€$ nominal and person-years)

\begin{tabular}{|c|c|c|c|c|c|c|}
\hline Industries & Activities & $\begin{array}{l}\text { Power } \\
\text { Classes }\end{array}$ & Profits & Income & Taxes & $\begin{array}{l}\text { Person- } \\
\text { Years }\end{array}$ \\
\hline \multirow{4}{*}{$\begin{array}{l}\text { Planning } \\
\text { Companies }\end{array}$} & \multirow{3}{*}{ Planning } & $\begin{array}{l}0<10 \mathrm{~kW} \\
(\mathrm{n}=227)\end{array}$ & 20,803 & 66,407 & 7,739 & 2.0 \\
\hline & & $\begin{array}{l}10<100 \mathrm{~kW} \\
(\mathrm{n}=45)\end{array}$ & 15,167 & 48,417 & 5,642 & 1.5 \\
\hline & & $\begin{array}{l}>=100 \mathrm{~kW} \\
(\mathrm{n}=8)\end{array}$ & 4,032 & 12,872 & 1,500 & 0.4 \\
\hline & Total & & 40,003 & 127,696 & 14,882 & 3.8 \\
\hline \multirow{4}{*}{$\begin{array}{l}\text { Financial } \\
\text { Institutions }\end{array}$} & \multirow{3}{*}{ Financing } & $\begin{array}{l}0<10 \mathrm{~kW} \\
(n=227)\end{array}$ & 14,660 & 19,267 & 4,105 & 0.5 \\
\hline & & $\begin{array}{l}10<100 \mathrm{~kW} \\
(\mathrm{n}=45)\end{array}$ & 13,935 & 18,315 & 3,902 & 0.5 \\
\hline & & $\begin{array}{l}>=100 \mathrm{~kW} \\
(\mathrm{n}=8)\end{array}$ & 13,987 & 18,383 & 3,917 & 0.5 \\
\hline & \multicolumn{2}{|l|}{ Total } & 42,582 & 55,966 & 11,924 & 1.5 \\
\hline \multirow{7}{*}{$\begin{array}{l}\text { Wholesale } \\
\text { Companies }\end{array}$} & \multirow{4}{*}{$\begin{array}{l}\text { Trade of Plant } \\
\text { Components }\end{array}$} & $\begin{array}{l}0<10 \mathrm{~kW} \\
(n=227)\end{array}$ & 17,530 & 43,354 & 5,433 & 1.6 \\
\hline & & $\begin{array}{l}10<100 \mathrm{~kW} \\
(\mathrm{n}=45)\end{array}$ & 11,258 & 27,907 & 3,501 & 1.0 \\
\hline & & $\begin{array}{l}>=100 \mathrm{~kW} \\
(\mathrm{n}=8)\end{array}$ & 7,015 & 17,733 & 2,242 & 0.7 \\
\hline & & $\begin{array}{l}0<10 \mathrm{~kW} \\
(\mathrm{n}=227)\end{array}$ & 3,586 & 8,801 & 1,069 & 0.3 \\
\hline & \multirow{2}{*}{$\begin{array}{l}\text { Trade of } \\
\text { Maintenance } \\
\text { Material }\end{array}$} & $\begin{array}{l}10<100 \mathrm{~kW} \\
(\mathrm{n}=45)\end{array}$ & 3,199 & 7,851 & 954 & 0.3 \\
\hline & & $\begin{array}{l}>=100 \mathrm{~kW} \\
(\mathrm{n}=8)\end{array}$ & 3,076 & 7,550 & 917 & 0.3 \\
\hline & \multicolumn{2}{|l|}{ Total } & 45,664 & 113,197 & 14,115 & 4.2 \\
\hline
\end{tabular}


Chapter 3

Table 3.3: Detailed overview about total regional value added and employment effects of PV plants installed in 2014 in the district of Aachen (in € nominal and person-years) (continued)

\begin{tabular}{|c|c|c|c|c|c|c|}
\hline Industries & Activities & $\begin{array}{l}\text { Power } \\
\text { Classes }\end{array}$ & Profits & Income & Taxes & $\begin{array}{l}\text { Person- } \\
\text { Years }\end{array}$ \\
\hline \multirow{10}{*}{$\begin{array}{l}\text { PV } \\
\text { Installation } \\
\text { Companies }\end{array}$} & \multirow{3}{*}{ Installation } & $\begin{array}{l}0<10 \mathrm{~kW} \\
(\mathrm{n}=227)\end{array}$ & 13,528 & 77,753 & 5,508 & 3.2 \\
\hline & & $\begin{array}{l}10<100 \mathrm{~kW} \\
(n=45)\end{array}$ & 10,079 & 57,932 & 4,104 & 2.4 \\
\hline & & $\begin{array}{l}>=100 \mathrm{~kW} \\
(\mathrm{n}=8)\end{array}$ & 6,791 & 39,034 & 2,765 & 1.6 \\
\hline & \multirow{3}{*}{ Maintenance } & $\begin{array}{l}0<10 \mathrm{~kW} \\
(\mathrm{n}=227)\end{array}$ & 17,217 & 98,958 & 7,011 & 4.1 \\
\hline & & $\begin{array}{l}10<100 \mathrm{~kW} \\
(n=45)\end{array}$ & 15,359 & 88,278 & 6,254 & 3.7 \\
\hline & & $\begin{array}{l}>=100 \mathrm{~kW} \\
(n=8)\end{array}$ & 14,769 & 84,889 & 6,014 & 3.5 \\
\hline & \multirow{3}{*}{ Uninstallation } & $\begin{array}{l}0<10 k W \\
(n=227)\end{array}$ & 13,528 & 77,753 & 5,508 & 3.2 \\
\hline & & $\begin{array}{l}10<100 \mathrm{~kW} \\
(n=45)\end{array}$ & 10,079 & 57,932 & 4,104 & 2.4 \\
\hline & & $\begin{array}{l}>=100 \mathrm{~kW} \\
(\mathrm{n}=8)\end{array}$ & 6,791 & 39,034 & 2,765 & 1.6 \\
\hline & \multicolumn{2}{|l|}{ Total } & 108,143 & 621,563 & 44,034 & 25.9 \\
\hline \multirow{7}{*}{$\begin{array}{l}\text { Grid } \\
\text { Service } \\
\text { Companies }\end{array}$} & \multirow{4}{*}{$\begin{array}{l}\text { Grid } \\
\text { Connection }\end{array}$} & $\begin{array}{l}0<10 \mathrm{~kW} \\
(\mathrm{n}=227)\end{array}$ & 10,014 & 10,206 & 2,576 & 0.3 \\
\hline & & $\begin{array}{l}10<100 \mathrm{~kW} \\
(n=45)\end{array}$ & 3,327 & 3,391 & 856 & 0.1 \\
\hline & & $\begin{array}{l}>=100 \mathrm{kWp} \\
(\mathrm{n}=8)\end{array}$ & 5,710 & 5,819 & 1,469 & 0.2 \\
\hline & & $\begin{array}{l}0<10 \mathrm{~kW} \\
(\mathrm{n}=227)\end{array}$ & 22,207 & 22,631 & 5,712 & 0.7 \\
\hline & \multirow[t]{2}{*}{ Meter Lease } & $\begin{array}{l}10<100 \mathrm{~kW} \\
(\mathrm{n}=45\end{array}$ & 4,402 & 9,545 & 4,486 & 0.3 \\
\hline & & $\begin{array}{l}>=100 \mathrm{~kW} \\
(n=8)\end{array}$ & 783 & 798 & 201 & 0.0 \\
\hline & Total & & 46,443 & 52,389 & 15,299 & 1.6 \\
\hline
\end{tabular}


Table 3.3: Detailed overview about total regional value added and employment effects of PV plants installed in 2014 in the district of Aachen (in $€$ nominal and person-years) (continued)

\begin{tabular}{|c|c|c|c|c|c|c|}
\hline Industries & Activities & $\begin{array}{l}\text { Power } \\
\text { Classes }\end{array}$ & Profits & Income & Taxes & $\begin{array}{l}\text { Person- } \\
\text { Years }\end{array}$ \\
\hline \multirow{4}{*}{$\begin{array}{l}\text { Plant } \\
\text { Operators }\end{array}$} & \multirow{3}{*}{$\begin{array}{l}\text { Electricity } \\
\text { Generation }\end{array}$} & $\begin{array}{l}0<10 \mathrm{~kW} \\
(\mathrm{n}=227)\end{array}$ & 530,425 & 0 & 60,502 & 0.0 \\
\hline & & $\begin{array}{l}10<100 \mathrm{~kW} \\
(\mathrm{n}=45)\end{array}$ & 768,325 & 0 & 86,918 & 0.0 \\
\hline & & $\begin{array}{l}>=100 \mathrm{~kW} \\
(\mathrm{n}=8)\end{array}$ & 248,685 & 141,985 & 36,894 & 4.0 \\
\hline & Total & & $1,547,435$ & 141,985 & 184,314 & 4.0 \\
\hline \multirow{4}{*}{$\begin{array}{l}\text { Insurance } \\
\text { Companies }\end{array}$} & \multirow{3}{*}{ Insurance } & $\begin{array}{l}0<10 \mathrm{~kW} \\
(n=227)\end{array}$ & 4,541 & 11,165 & 1,452 & 0.3 \\
\hline & & $\begin{array}{l}10<100 \mathrm{~kW} \\
(\mathrm{n}=45)\end{array}$ & 1,017 & 2,499 & 325 & 0.1 \\
\hline & & $\begin{array}{l}>=100 \mathrm{~kW} \\
(\mathrm{n}=8)\end{array}$ & 621 & 1,527 & 199 & 0.0 \\
\hline & Total & & 6,179 & 15,191 & 1,976 & 0.4 \\
\hline \multirow{3}{*}{ Landlords } & \multirow{2}{*}{ Roof Lease } & $\begin{array}{l}>=100 \mathrm{~kW} \\
\text { (private) }\end{array}$ & 200,151 & 0 & 21,740 & 0 \\
\hline & & $\begin{array}{l}>=100 \mathrm{~kW} \\
\text { (public) }\end{array}$ & 290,460 & 0 & 0 & 0 \\
\hline & \multicolumn{2}{|l|}{ Total } & 490,611 & 0 & 21,740 & 0 \\
\hline $\begin{array}{l}\text { Tax } \\
\text { Advisory } \\
\text { Companies }\end{array}$ & Tax Advisory & $\begin{array}{l}>100 \mathrm{~kW} \\
(\mathrm{n}=8)\end{array}$ & 7,081 & 22,605 & 2,634 & 0.7 \\
\hline \multicolumn{3}{|l|}{ Total } & $2,334,140$ & $1,150,593$ & 310,918 & 42.2 \\
\hline \multicolumn{2}{|c|}{ Installation } & \multicolumn{2}{|c|}{ O\&M } & & \multicolumn{2}{|c|}{ Decomissioning } \\
\hline
\end{tabular}

Most of the employment effects arise in the PV installation industry with approximately 26 person-years, or $62 \%$ of the total employment effects. Other employment effects are relatively lower. The comparison of income and employment effects shows that relatively high employment effects per total income occur in the PV installation industry. That is due to lower employment compensation compared to other industries. Therefore, there is a need to provide additional information about the 
calculation of the effects, like providing the average income in the specific industries where the employment effects occur.

Complementary to Table 3.3 that depicts the total aggregated value added of the plants installed in 2014, Table 3.4 illustrates further characteristics of the sample. The minimum value added ranges from $€-413$ for a $1.3 \mathrm{~kW}$ plant to $€ 211,986$ for a 180.0 kW plant. For smaller plants, fix costs of plants have a greater impact on the profits of plant operators than for larger plants which negatively affects the profits of plant operators and conclusively the value added which explains the negative result of the $1.3 \mathrm{~kW}$ plant. According to the used model and data, system capacities' should be minimum $2.5 \mathrm{~kW}$ for a profitable operation.

Table 3.4: Minimum, maximum, and mean regional value added of PV plants in the power classes

\begin{tabular}{llll}
\hline $\begin{array}{l}\text { Power } \\
\text { Class }\end{array}$ & $\begin{array}{l}\text { Mean value } \\
\text { added }\end{array}$ & $\begin{array}{l}\text { Minimum value } \\
\text { added }\end{array}$ & $\begin{array}{l}\text { Maximum value } \\
\text { added }\end{array}$ \\
\hline $0<10 \mathrm{~kW}$ & $€ 5,125(6.0 \mathrm{~kW})$ & $€-413(1.3 \mathrm{~kW})$ & $€ 10,189(9.84 \mathrm{~kW})$ \\
$10<100 \mathrm{~kW}$ & $€ 28,686(26.9 \mathrm{~kW})$ & $€ 10,690(11.4 \mathrm{~kW})$ & $€ 98,709(99.5 \mathrm{~kW})$ \\
$>=100 \mathrm{~kW}$ & $€ 162,838(145.2 \mathrm{~kW})$ & $€ 128,295(114.4 \mathrm{~kW})$ & $€ 211,986(180.0 \mathrm{~kW})$ \\
\hline
\end{tabular}

Conclusively, it can be stated that the greater the capacity of plants, the higher are the regional economic effects.

The estimated municipal tax revenues from the deployment of PV in 2014 totaled $€ 56,000$, represent $0.01 \%$ of the total municipal share of income-, and trade taxes in the district of Aachen (IT.NRW 2017a). Noted, however, that corporate taxes are included in the taxes in the district and only the plants installed in 2014 are recorded. The total municipal tax effects of the facilities installed in 2014 yield $€ 311,000$ over their presumed lifetime from 2014 to 2034, representing $0.07 \%$ of the share of income- and trade tax in 2014.

The results show 16 fulltime jobs in 2014 which is $0.008 \%$ of the total employment in June 2014 in the district of Aachen (IT.NRW, 2017b). If all effects related to the plants installed in 2014 were supposed to occur in 2014 it would be $0.02 \%$ of total employment in the region. In comparison to the employment effects of the open lignite mine Inden 
and the power plant Weisweiler in 2009 (approximately 2,672 employees ${ }^{34}$ ) the total effects of PV plants installed in 2014 account for a share of $1.6 \%$ of employment effects. The lignite industry accounts for 0.2 jobs per GWh electricity generated, whereas PV developments lead to 4.8 jobs per GWh electricity generated in 2014 in the region.

As the generation of electricity by PV may lead to a crowding out of conventional power generation, this may have an effect on the regional economy which relies on the lignite industry. According to Memmler et al. (2014, based on Klobasa and Sensfuß, 2013), PV substitutes 3\% of electricity generated by lignite. Therefore, the generation of electricity leads to a substitution of $101 \mathrm{MWh}$ electricity generated by lignite per year. This implies only marginal negative employment effects of 0.01 less employees.$^{35}$

\subsubsection{Comparison of the results to other studies in the field}

To compare the results to existing work in the field, studies that carried out a comparable analysis of effects of PV plants in German regions, examining a regional value added, consisting of profits, income and regional taxes have been chosen. Studies' results on an international level such as Simons and Peterson (2001) or Bezdek (2007) are illustrated more aggregated, which does not allow to evaluate the impacts in the specific lifecycle stages and the assessed regional economic effects vary regarding the indicator regional value added as defined and evaluated in this paper, which hinders a comparability.

Bröcker et al. (2014) assessed the value added for the Land Schleswig-Holstein taking taxes into account which occur on Land level as well, whereas the other studies regard taxes on municipal scale only, which leads to lower taxes and therefore to a lower regional value added. BMVBS (2011) define the costs for activities in the operation stage as income costs and material costs and define all income costs as incomes of employees, without differentiating between employee income and profits and taxes of enterprises, while the latter two components of the value added are not calculated for the operation stage (BMVBS, 2011), which leads to a relatively high value added as well. The studies' results are illustrated for the stages installation, operation (while displaying the activity electricity generation separately) and decommissioning.

34 Employment effects of RWE Power AG have been evaluated by multiplying the employees of RWE Power AG in the lignite mine Inden and the power plant Weisweiler (1,600 employees according to RWE Power AG, 2009) by an average employment multiplier for the Rhenish lignite mining region (1.67 in 2009) according to EEFA, 2010.

35 In this calculation, a linear correlation between the 1,600 RWE employees in 2009 and the electricity generated in 2014 (15.3 TWh) has been assumed. 
Because of different cost structures (Table 3.1), only small PV plants (0-10 kW) that are usually installed on top of, for instance, single family homes (Table 3.2) are considered. Bröcker et al. (2014), Hirschl et al. (2010), and BMVBS (2011) distinguish between two types of rooftop PV plants - small and large. A differentiation between three power classes for rooftop PV plants as in this paper has not been made, which is of course dependent upon available cost data.

Hirschl et al. (2010) explore the potentials by assuming a 100\% regional share of activities taken over by enterprises in a region (i.e. a community in Hirschl et al. (2010)), BMVBS (2011) and Bröcker et al. (2014) assume individual shares for activities executed by regional enterprises. In the Aachen region, regional shares are assumed as well and the regional economic potentials are explored first by identifying individual enterprises in the region, which has not been done by another study to such an extent.

After harmonising data assessments, ${ }^{36}$ results of the installation stage range between $€ 207$ and $€ 412$ per kW in this stage (Table 3.5). The differences in the results are mainly explicable because of differences in costs for plants which have dramatically decreased along past years. Whereas Hirschl et al. (2010), for example, assumed prices of $€ 1,566 € /$ $\mathrm{kW}$ for modules and $€ 331 / \mathrm{kW}$ for inverters, prices for the Aachen region were assumed as $€ 624 / \mathrm{kW}$ for modules and $€ 176 / \mathrm{kW}$ for inverters. Furthermore, the plant assembly costs vary from $€ 304 / \mathrm{kW}$ Hirschl et al. (2010) to $€ 176 / \mathrm{kW}$ (own results) which may be explicable due to learning effects of installation companies.

For the operation stage, all authors assume a lifetime of 20 years. The results in Table 3.5 illustrate the total effects per kW for 20 years of operation. BMVBS (2011) did not include the value added of the activity financing, because they classified it as the direct effects occurring during electricity generation, which is included into the operation stage (Figure 3.3) for the Aachen region. Moreover, total interests have been interpreted as a component of regional value added without considering a disaggregation of interests into taxes of banks, income of employees, or further costs of banks, which leads to a relatively high value added for operation. Results vary

36 Hirschl et al. (2010) and Bröcker et al. (2014) summarised the wholesale of modules and inverters under their defined stages 'investment' or 'plant components' that include manufacturing of modules as well. As for the Aachen region, the results for wholesale of modules and inverters are integrated into the installation stage. Manufacturing of installation material as included by Hirsch et al. (2010) is excluded. 
between $€ 179 / \mathrm{kW}$ (Aachen region) ${ }^{37}$ and $€ 2,366 / \mathrm{kW}$ (Bröcker et al., 2014) in this stage. Differences are explicable by decreased maintenance material costs (Hirschl et al., 2010 and this paper's results), additional cost positions and methodological differences. ${ }^{38}$

For electricity generation, value added depends on capacity, as well as on the full load hours of the plant varying with location (800 h (Schleswig-Holstein) to $934 \mathrm{~h}$ (Nordschwarzwald)). Value added is illustrated in $€$ per kWh electricity generated, in order to account for the different locations. Regarding the results one sees significant differences. They are partly explicable because of different costs for installation and operation which have an impact on the profits (and therefore taxes) of operators. Other important aspects are the global irradiation potentials of the regions and the decrease of feed-in tariffs. Whereas Hirschl et al. (2010) calculated with a feed-in tariff of $€ 0.4301 / \mathrm{kWh}$ according to EEG 2009, Bröcker et al. (2014) calculated with an average feed-in tariff of $€ 0.1529 / \mathrm{kWh}$ according to EEG 2012, which is almost three times less than the feed-in tariff of Hirschl et al. (2010). The fact, that operation costs in Hirsch et al. (2010) are lower than in all other studies (except for this study) explains why their value added in electricity generation is much higher than in other studies. Bröcker et al. (2014) is the only study where a negative value added concerning the activity electricity generation is presented. This is due to the relatively high costs for operation, and that benefits of operators were assessed the by taking the profits generated by feed-in tariff only into account, which is lower than the electricity prices in 2012, and not considering internal consumption.

The stage decommissioning is only taken in this study into account, whereas a regional value added for the activity uninstallation have only been assessed in the Aachen region.

37 The difference between $€ 179 / \mathrm{kW}$ for small plants between 1-10 kW and €302/kW for PV plants in general (Section 3.3.3) are explicable because the latter include tax advisory services and roof lease for PV plants above $100 \mathrm{~kW}$.

38 Bröcker et al. (2014) and BMVBS (2011) included tax advisory services in their calculations, which have not been considered in Hirschl et al. (2010) and this paper's results for small PV plants. Bröcker et al. (2014) included the costs for e.g. retrofitting requirements which are not included in other studies and assume a relatively high value added for maintenance ( 6 times Hirschl et al., 2010). The relatively high values of BMVBS (2011) are due the interpretation of interests as component of value added. 
Chapter 3

Table 3.5: Total regional value added of PV plants (0-10 kW) in different studies in $€ / \mathrm{kW}$ installed capacity and in $€ /$ kWh electricity generated

\begin{tabular}{|c|c|c|c|c|c|c|}
\hline \multirow[b]{2}{*}{ Region } & \multirow[b]{2}{*}{$\begin{array}{l}\text { NUTS } \\
\text { Level }\end{array}$} & \multirow[b]{2}{*}{$\begin{array}{l}\text { Instal- } \\
\text { lation } \\
€ / \mathbf{k W}\end{array}$} & \multicolumn{2}{|c|}{ Operation } & \multirow[b]{2}{*}{$\begin{array}{c}\text { Decommis- } \\
\text { sioning } \\
€ / \mathbf{k W}\end{array}$} & \multirow[b]{2}{*}{ Source } \\
\hline & & & $\begin{array}{c}\text { Operation } \\
€ / \mathbf{k W}\end{array}$ & $\begin{array}{c}\text { Electricity } \\
\text { Generation } \\
€ / \text { kWh }\end{array}$ & & \\
\hline Friesland & NUTS 3 & - & 1,296 & 0.055 & - & $\begin{array}{c}\text { BMVBS } \\
(2011)\end{array}$ \\
\hline $\begin{array}{l}\text { Nordschwarz- } \\
\text { wald }\end{array}$ & $\begin{array}{c}\text { Four } \\
\text { aggregated } \\
\text { NUTS } 3 \\
\text { regions }\end{array}$ & - & 1,296 & 0.056 & - & $\begin{array}{c}\text { BMVBS } \\
(2011)\end{array}$ \\
\hline Hannover & NUTS 3 & - & 1,296 & 0.040 & - & $\begin{array}{c}\text { BMVBS } \\
(2011)\end{array}$ \\
\hline Trier & NUTS 2 & - & 1,296 & 0.051 & - & $\begin{array}{c}\text { BMVBS } \\
(2011)\end{array}$ \\
\hline $\begin{array}{l}\text { Schleswig- } \\
\text { Holstein }\end{array}$ & NUTS 1 & 412 & 2,366 & -0.078 & - & $\begin{array}{c}\text { Bröcker } \\
\text { et al. } \\
\text { (2014) }\end{array}$ \\
\hline $\begin{array}{c}\text { Municipalities } \\
\text { in Germany in } \\
\text { General }\end{array}$ & LAU 2 & 357 & 330 & 0.120 & - & $\begin{array}{l}\text { Hirschl } \\
\text { et al. } \\
(2010)\end{array}$ \\
\hline $\begin{array}{c}\text { Städteregion } \\
\text { Aachen }\end{array}$ & NUTS 3 & 207 & 179 & 0.024 & 71 & $\begin{array}{l}\text { This } \\
\text { Paper }\end{array}$ \\
\hline
\end{tabular}

(Source: own calculation and aggregation based on BMVBS (2011), Bröcker et al. (2014) and Hirschl et al. (2010), nominal values)

In summary, the comparison of the studies' results shows the dynamics in the German PV market regarding decreasing system costs and changes in business opportunities for operators (feed-in tariff vs. PV electricity consumption). The positive regional value added is decreasing because of lower system costs and learning effects. Furthermore, lower system costs do not compensate the losses in value added for operators because of decreasing feed-in tariffs. Nevertheless, profits for operators are supposed to rise in the future because of further decreases of PV plant component prices (Schröder 
et al., 2013) and increasing electricity prices (Figure 3.6) making investments into PV more attractive.

\subsection{Estimating the impact of PV on avoided greenhouse gas emissions and air pollution}

\subsubsection{Avoided GHG emissions due to PV deployment}

As a climate mitigation strategy, it is aimed achieve a reduction of $\mathrm{CO}_{2}$ emissions of $40 \%$ until 2020 and $80 \%$ by 2050 in the Aachen district (StädteRegion Aachen, 2011).

To include total emissions of energy generation systems, a lifecycle assessment (LCA) may be used to calculate the emissions of a product (e.g. PV) during the whole product lifetime from the extraction of material, manufacturing, usage, till waste management (Rebitzer et al., 2004). A compilation of LCA assessment studies that includes PV has been done by for example Sherwani et al. (2010), Nugent and Suvacool (2014), Louwen et al. (2015), and Turconi et al. (2013).

In this paper, data of avoided emissions due to PV deployment in Germany has been evaluated by the Federal Environmental Agency, using a LCA approach (Memmler et al., 2014). GHG emissions of PV plants may be slightly underestimated because emissions during plant operation and emissions regarding the plant components inverters and cables are neglected (Memmler et al., 2014). As data for 2014 was not available, data of 2013 is used. In 2013, GHG emissions of PV deployment are estimated at $55 \mathrm{gCO}_{2}$-eqivalents (eq)/kWh (Memmler et al., 2014). Comparing these emissions with values from different studies, Nugent and Suvacool (2014) calculated a mean of $49.9 \mathrm{gCO}_{2}$-eq/kWh in a comprehensive literature analysis.

Avoided emissions depend on the substitution potentials of a technology. In case of PV, due to fluctuating feed-in because of day and night and seasonal differences, mostly hard coal and natural gas power generation may be substituted (Memmler et al., 2014). Avoided emissions in 2013 are estimated $761 \mathrm{gCO}_{2}$-eq/kWh (Memmler et al., 2014). Subtracting the emissions of PV deployment leads to net avoided emissions of $706 \mathrm{gCO}_{2}$-eq/kWh. Although, emissions, generated by PV systems occur not equally distributed during their lifetime because component manufacturing takes place in or before 2014, an equal distribution is assumed in order to estimate the emissions of PV per year. Following the assumptions regarding electricity generation by PV plants in the region (see Section 3.3.2.3), the net avoided GHG emission potential of PV of the 
plant sample would be 2,365 $\mathrm{tCO}_{2}$-eq in 2014, if all plants had been installed before the beginning of the year. $\mathrm{CO}_{2}$ only makes 2,194 (93\%) of emissions.

In order to estimate the economic benefits of non-emitted GHGs the paper follows the European Environmental Agency (EEA, 2014), using the market price of the European Union (EU) European Emission Trading System (ETS) and, secondly, the social cost of carbon (SCC). The mean value of for a ton of $\mathrm{CO}_{2}$ traded at the European Energy Exchange (EEX) in 2014 is $€ 5.42$ (calculations based on European Energy Exchange AG, 2017).

The economic value is $€ 11,891$ ( $€ 0.004 / \mathrm{kWh}$ electricity generated) in 2014 which is calculated by multiplying the avoided $\mathrm{CO}_{2}$ with the ETS allowance price. As the ETS price varies widely and decreased very much in recent years (Koch et al., 2014), the SCC approach is presented as a second method.

Social cost of carbon estimate the "economic cost caused by an additional ton of carbon dioxide emissions" (Nordhaus, 2014:273). The SCC estimates the avoided damage (or external) costs due to the mitigation of a ton of GHG today by taking future damage costs into account, based upon assumptions on climate change effects (EEA, 2014). SCC includes a growth rate for "marginal damage costs" (Tol, 2013:913), meaning that costs increase within time (Ackerman and Stanton, 2012; Bateman et al., 2014).

Estimating a value for the SCC, it can be referred to a comprehensive review by Isacs et al. (2016) who present a lower and a higher value of the SCC. The lower value $(€ 5.8$ per ton $\mathrm{CO}_{2}$ in $2014^{39}$ ) consists of a mean global estimate, based on calculations of Tol (2013). This price, which is comparable to the ETS price is lower than in other studies and can therefore be seen as a value based on assumptions including relatively "low climate sensitivity, less importance of future generations compared to current [...], and less risk concern" (Isacs et al., 2016:45).

Higher SCC estimations are based on "high climate sensitivity, an equally important weight put on future generations as that of the current [...], and the inclusion of possible catastrophic climate change" (Isacs et al., 2016:45). Following the higher estimations by Ackerman and Stanton (2012) in Isacs et al. (2016), yields to costs of

39 Isacs et al. (2016) present a value of $€ 6.1$ per $\mathrm{tCO}_{2}$ in 2015 which they calculate based on Tol (2013) and Bateman et al. (2014). To calculate the SCC value for 2014, a damage growth rate of 2.3\% p.a. as presented by Tol (2013) and an inflation rate of Germany based on OECD (2017b) to calculate $2014 €$ prices is used. 
$€ 698$ per ton of $\mathrm{CO}_{2}$ in $2014 .{ }^{40}$ To take the range of SCC values into account van den Bergh and Botzen (2014) present $€ 94$ per ton $\mathrm{CO}_{2}$ in $2014^{41}$ as a threshold which can be "considered a realistic and conservative value" (van den Bergh and Botzen, 2014:256). This is, therefore, used in the calculations of the SCC value. Taking the emissions of PV systems into account, leads to a SCC value of $€ 206,220(€ 0.06 / \mathrm{kWh}$ electricity generated).

The variables influencing the value are hard to quantify and may alter in the future (Isacs et al., 2016). Nevertheless, the SCC values illustrate a range of occurring damage costs which are dependent upon potential future developments.

\subsubsection{Avoided air pollutant effects and their economic impact}

Conventional energy generation induces air pollution effects which lead to negative effects for the environment and provokes negative health effects like lung- or cardiovascular damages (Remais et al., 2014). Preiss et al. (2013) for instance estimate annual negative effects of 33,000 years of life lost (YOLL) and 700,000 working days lost (wdl) because of 67 coal power plants operating in Germany in 2010.

Concerning the spatial dispersion of effects, there are different levels of damages in different countries due to the reason that ecosystems or the population density and the emitters of air pollutants are not equally distributed and there are therefore regions which are more or less affected. Moreover, effects and damages vary upon the diffusion of the emissions and "differences in atmospheric chemistry (such as chemical transformation rates)" (EEA, 2014:26) which depends on the position of the emission source. Additionally, specific emissions tend to diffuse in the direction of the sea, which has a more severe impact on countries with access to the sea than for countries without a coastline (EEA, 2014). Therefore, there is a need to assess the effects of emissions at least country specific.

As for GHG emissions, the paper follows Memmler et al. (2014) to assess the amount of avoided pollutants due to PV deployment in the region of Aachen to rely on a consistent methodology for all avoided emissions. In 2014, the avoided emissions due to PV deployment in the region of Aachen (Table 3.6), account for 1.48t Nitrogen oxides $\left(\mathrm{NO}_{\mathrm{x}}\right)$ per year, $0.97 \mathrm{t}$ Sulphur dioxide $\left(\mathrm{SO}_{2}\right)$ per year, and $0.07 \mathrm{t}$ Non-methane volatile

40 Isacs et al. (2016) illustrate costs of $€ 724$ per $\mathrm{tCO}_{2}$ in 2015 , based on the estimations Ackerman and Stanton 2012. To calculate a value for the year 2014, the growth rate of damage costs per year (1.7\%) and the inflation rate for Germany based on OECD (2017b) are integrated.

41 The original value of $\$ 125$ per $\mathrm{tCO}_{2}$ of van den Bergh and Botzen (2014) has been transformed into $€$ by using the mean exchange rate of 2014 (Deutsche Bundesbank, 2017). 
organic compounds (NMVOCs) per year. On the other hand, PV deployments induce emissions of dust (0.02t per year) and (3.64t per year) of Carbon monoxide (CO).

Monetising costs of pollution due to these emissions, data for Germany provided by EEA (2014) that assessed the damages due to air pollution by European industrial facilities from 2008 to 2012 is used.

The economic effects of air pollutants are expressed in the value of a life year (VOLY) and a value of a statistical life (VSL), which is higher than the VOLY. VOLY expresses the damaging costs dependent upon the life expectancy (in YOLLs), whereas deaths of younger human beings are more weighted than deaths of elder human beings. The VSL expresses people's willingness to pay (wtp) for a decrease of the threat of health damages (EEA, 2014).

By taking the emissions of PV plants into account, a VOLY of $€ 32,000(€ 0.01 / \mathrm{kWh}$ electricity generated) in 2014 is calculated. The VSL of $€ 95,000$ ( $€ 0.028 / \mathrm{kWh}$ electricity generated) is approximately three times higher.

Table 3.6: Avoided air pollution and economic valuation in 2014

\begin{tabular}{llllll}
\hline Substance & $\begin{array}{l}\text { Net avoided } \\
\text { air pollution }(\mathbf{t})\end{array}$ & $\begin{array}{l}\text { VOLY } \\
(\boldsymbol{\epsilon} / \mathbf{t})\end{array}$ & $\begin{array}{l}\text { VSL } \\
(\boldsymbol{\epsilon} / \mathbf{t})\end{array}$ & $\begin{array}{l}\text { Economic value } \\
\text { of avoided air } \\
\text { pollution }(\boldsymbol{\epsilon})\end{array}$ & $\begin{array}{l}\text { Economic value } \\
\text { of avoided air } \\
\text { pollution }(\boldsymbol{\epsilon})\end{array}$ \\
\hline SO $_{2}$ & 0.97 & 21,316 & 64,684 & 20,610 & 62,542 \\
$\mathbf{N O}_{\mathbf{x}}$ & 1.48 & 7,666 & 21,431 & 11,369 & 31,786 \\
\hline NMVOCs $^{42}$ & 0.07 & 2,126 & 5,366 & 144 & 364 \\
\hline Total & & & & $\mathbf{3 2 , 1 2 3}$ & $\mathbf{9 4 , 6 9 1}$ \\
\hline
\end{tabular}

(Source: own calculations based on Memmler et al. (2014) (emissions) and EEA (2014) (economic assessment $\left.{ }^{43}\right)$ )

It should be considered that these benefits do not all occur in the Aachen region, as it is hard to map the spatial distribution of emission reductions due to PV, since the power grid is integrated. Hence, emission reductions may take place outside the region.

42 EEA (2014) include secondary organic aerosols (SOA) into NMVOCs as well, whereas it is not clear whether they are included in the calculations of Memmler et al. (2014).

43 The values of EEA (2014) were originally in $2005 €$, which have been converted using an inflation rate for Germany based on OECD (2017b). 


\subsection{Conclusions and policy implications}

The results of the supply chain analysis in the region illustrate overall economic effects of $€ 3.8$ million, which include the components profits ( $€ 2.3$ million) net incomes ( $€ 1.2$ million), and regional taxes ( $€ 0.3$ million). The regional economic effects are $€ 1,019$ per kW for the installed plants with a total cumulative capacity of $3,724 \mathrm{~kW}$ and $€ 57$ per MWh electricity generated with a total electricity generation of $67,032 \mathrm{MWh}$.

In 2014, the regional value added accounts for $€ 729,000$ ( $€ 196$ per kW, $€ 218$ per MWh) the benefits of avoided $\mathrm{CO}_{2}$ are $€ 12,000-206,000$ ( $€ 3-55$ per kW, $€ 4-62$ per MWh) and the benefits of avoided air pollution range from $€ 32,000$ to $€ 95,000$ ( $€ 9-25$ per kW, $€ 10-28$ per MWh). Total effects range from $€ 773,000-1,030,000$ ( $€ 208-277$ per kW, $€ 231$ 307 per MWh). Employment effects are 16 person years ( 0.004 person years per kW, 0.005 person years per MWh) (Table 3.7).

Table 3.7: Economic effects of plants installed in 2014 in $€$, $€ / \mathrm{kW}$, and $€ / M W h$ in 2014

\begin{tabular}{lllll}
\hline Indicator & Component & Total in $\boldsymbol{\epsilon}$ & $\boldsymbol{\epsilon} / \mathbf{k W}$ & $\boldsymbol{\epsilon} / \mathbf{M W h}$ \\
\hline \multirow{2}{*}{ Value Added } & Profits & 234,181 & 63 & 70 \\
& Income & 439,078 & 118 & 131 \\
& Taxes & 56,095 & 15 & 17 \\
\hline Avoided $\mathrm{CO}_{2}$ & $\mathrm{CO}_{2}$ & $11,891-206,220$ & $3-55$ & $4-62$ \\
\hline \multirow{2}{*}{ Avoided Air } & $\mathrm{SO}_{2}$ & $20,610-62,542$ & $6-17$ & $6-19$ \\
Pollution & $\mathrm{NO}_{x}$ & $11,369-31,786$ & $3-9$ & $3-10$ \\
\hline Total & $\mathrm{NMVOCs}^{*}$ & $144-346$ & $0.04-0.1$ & $0.04-0.1$ \\
\hline
\end{tabular}

The applied supply chain approach is a useful method to evaluate the effects of regional renewable energy deployments, because it is illustrative and easily adaptable when specific cost structures are available. As the benefits for specific economic actors are illustrated very detailed, the approach is beneficial for organisations like industry associations to evaluate the benefits for specific industries. Moreover, these assessments support RES, as demonstrating the benefits of renewable energies to decision makers may lead to increasing developments of RES. In comparison to other studies, data for three different power classes of PV systems has been used, taking the different cost structures of various plant classes into account which makes this paper's analysis more precise, than using two power classes only. The quality of assessments depends on the availability of current data. It is therefore needed, to continuously assess data of the costs developments of the PV industry on a high disaggregation 
level. Moreover, there is a need to study the regional effects of PV on an international level, as such regional impact assessments have rarely been conducted outside Germany.

Most of the effects are due to operation (approximately half of the total effect). The profits of plant operators depend mainly on the (self-)consumption of generated PV electricity. Higher consumption may be achievable by a more efficient load management or storage systems, which are expected to be economically deployable in the future. The ongoing integration of renewable energy prosumers in the electricity market is a threat to traditional business models of established incumbents like traditional power supply companies. Therefore, there is need for research to define the role of power supply companies in the future energy market.

Taking into account the external benefits of avoided GHGs and air pollution and monetising them is a suitable approach for making benefits illustrative for decision makers. Especially for external costs there is a need for research to realistically estimate the costs of future damage costs and to integrate them in assessments. However, the success of a regional energy transition depends on many other issues as the motives of regional stakeholders, legal situation, acceptance of RES, etc. In that case, interdisciplinary research which combines economic findings with outcomes from other disciplines may be beneficial.

Finally, the development of PV is only a component of a regional energy transition as an analysis of the regional potential shows up that rooftop PV is unable to fully cover the region's electricity demand. Therefore, in an overall analysis of a region's energy demand and supply options there is a need to integrate other energy sources, as well as flexible demand and storage potentials for volatile energy sources such as PV or wind power (Perez-Arriaga and Batlle, 2012). This also has economic effects, which are not explicitly considered in this study. Further analyses may, however, use data of individual studies like this as a component to study the overall effect of a regional energy transition in an integrated approach. 


\section{Acknowledgements}

The outcomes presented in this paper have been assessed in the render (Regional Dialogue Energy Transition) project that is part of the FONA (Research for Sustainable Development) programme funded by the of the German Federal Ministry of Education and Research (BMBF) (FKZ 033L116G). The authors gratefully acknowledge funding from the FONA programme of the BMBF. We are also grateful to Tobias Kelm for the permission to reproduce Table 3.2, originally illustrated in Kelm (2015) (cf. References). 



\section{Regional Economic and Environmental Impacts of Wind Power Developments: A Case Study of a German Region

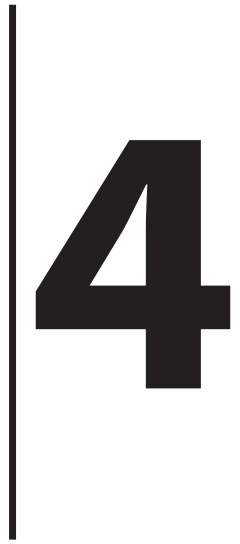

This chapter is based on the publication: Jenniches S, Worrell E, Fumagalli E. Regional economic and environmental impacts of wind power developments: A case study of a German region. Energy Policy 2019;132:499-514. https://doi.org/10.1016/j.enpol.2019.05.046. 


\section{Abstract}

Wind power is an important technology in the transition towards a low carbon economy. This paper covers the regional impacts of wind power developments in a small German region. Wind power developments with a cumulative capacity of 63.1 MW which have been installed in 2017 in the Aachen region, generating 3,901 GWh electricity from 2017 to 2037 lead to a regional value added of $€ 50.8$ million (or $€ 805 / \mathrm{kW}$ ). The avoided greenhouse gas emissions are $132,770 \mathrm{tCO}_{2}$-equivalents in 2017 and the total economic impacts of value added, avoided greenhouse gases and air pollution ranging from $€ 20.9$ to $€ 24.6$ million ( $€ 332-389$ per kW or $€ 107-126$ per MWh electricity generated) in 2017. From an environmental economic view, the generation of wind power is the most beneficial electricity generation technology in comparison to PV and lignite. 


\subsection{Introduction}

As acknowledged by most climate scientists, climate change, which has significant negative effects on the environment, is caused by the emission of greenhouse gases (GHG) such as carbon dioxide $\left(\mathrm{CO}_{2}\right)$ (NASA, 2017). Therefore, the avoidance of GHG, which has been adopted by international treaties such as the Kyoto Protocol and most recently by the Paris Agreement, is one of the main present and future societal targets and challenges (UNFCCC, 2014).

As most GHGs are emitted by the energy sector (IPCC, 2014) there is especially a need to reduce emissions in this sector by the exploitation of renewable energy sources (RES).

In terms of installed capacities, wind power is, after hydro power, the most important renewable energy technology, whose significance is expected to increase in the future (REN21, 2018) and may therefore be regarded as a significant contributor to a lower carbon energy system.

However, the energy transition to a low carbon energy system has not only positive impacts. Critics point out for example job losses in conventional energy industries (dpa, 2014) and regions where conventional energy carriers play a significant role, such as the Rhenish lignite mining area (EEFA, 2010), are particularly affected. Nevertheless, there are opportunities for a more sustainable regional development that encompasses environmental and socioeconomic concerns (Hopwood et al., 2005), even in regions that historically relied heavily on fossil fuels. These chances should be quantified to realistically estimate future economic opportunities in regions such as the district of Aachen (German: Städteregion Aachen), which historically relied on coal, still mines lignite, and finds itself in a transformation process to a low carbon energy system. Indeed, studies of this sort have policy relevant implications, for instance in Germany, where the envisaged phasing out of lignite in 2035 is expected to impact all regions currently relying on fossil fuel industries (Kommission Wachstum, Strukturwandel und Beschäftigung, 2019). The region may, therefore, be representative for a region relying on fossil fuel industries. There are other regions in a similar situation and each one should be studied individually, due to the local situation.

The aim of the paper is therefore to comprehensively show the current regional economic and environmental effects of developing RES like wind power and comparing these to conventional energy generation technologies. While a number of studies have looked at the economic implications of wind power development at the regional level, only a few take into account both economic and environmental 
effects. Yet, illustrating both dimensions at the regional level is extremely important from a policy perspective, as in most countries, regional and local governments (e.g. states, provinces, or municipalities) are key decision makers in the energy transition. In more details, Jenniches and Worrell (2019) find that most studies covering regional economic impacts of renewable energies purely focus on economic effects and do not take into account further effects such as the positive impacts of avoided emissions (GHG or air pollution), which may be referred to as positive externalities. Exceptions are Madlener and Koller (2007), Stoddard et al. (2006), or Bost et al. (2012). Evaluations mostly conclude with a quantification of the emissions and a monetary valuation of effects is not integrated (an exception is Simons and Peterson, 2001). Most studies in the field, moreover, present a simple substitution of one energy carrier by wind power without taking into account the effects of the integration of wind power on the actual electricity generation mix (Novan, 2015). On the contrary, the positive externalities of renewable energy generation on avoided emissions should also be integrated as a contribution of a region to climate change mitigation. This is especially relevant in regions where fossil fuel generation takes place and a compensation of the negative effects of the transition is strongly required due to a regional responsibility (Chen and Chen, 2011; Kinzig and Kammen, 1998) and from a sustainable development perspective (Dincer, 2000). In fact, a valuation of these effects enables a hands-on quantification showing the positive aspects of RES for all regional stakeholders (e.g. politicians, end-users, and businesses) in comparison to fossil energy generation technologies.

Consistently, this paper presents a comprehensive analysis of the regional economic effects of wind power deployment, supplemented by the estimation of the monetised positive impacts of avoided emissions, based on the current energy mix. As the market evolves quite dynamically in terms of technological and economic development (Deutsche Windguard, 2015), an up-to-date assessment is carried out in the paper by evaluating developments for the most recent year (2017).

Moreover, the paper assesses the current benefits of wind power and PV compared to lignite. Such a comparison is at the center of recent discussions about the future of lignite in the German energy system, as regional stakeholders decide on developments in their regions (Schmidt-Mattern, 2018).

The paper is structured as follows: After the introduction (Section 4.1), the characteristics of the analysed region with a special emphasis on the energy system are introduced (Section 4.2). Section 4.3 introduces the method to evaluate the economic impacts of RES in regions, which is then applied to the Aachen region. Section 4.4 
assesses the monetary value of environmental benefits of wind power developments, while the concluding section discusses the findings and provides a comparison on the benefits of the renewable energy technologies wind power and PV to the fossil energy carrier lignite.

\subsection{Characteristics of the region and wind power developments}

The district of Aachen is situated in the West of Germany (Figure 4.1) in the federal state North Rhine-Westphalia.

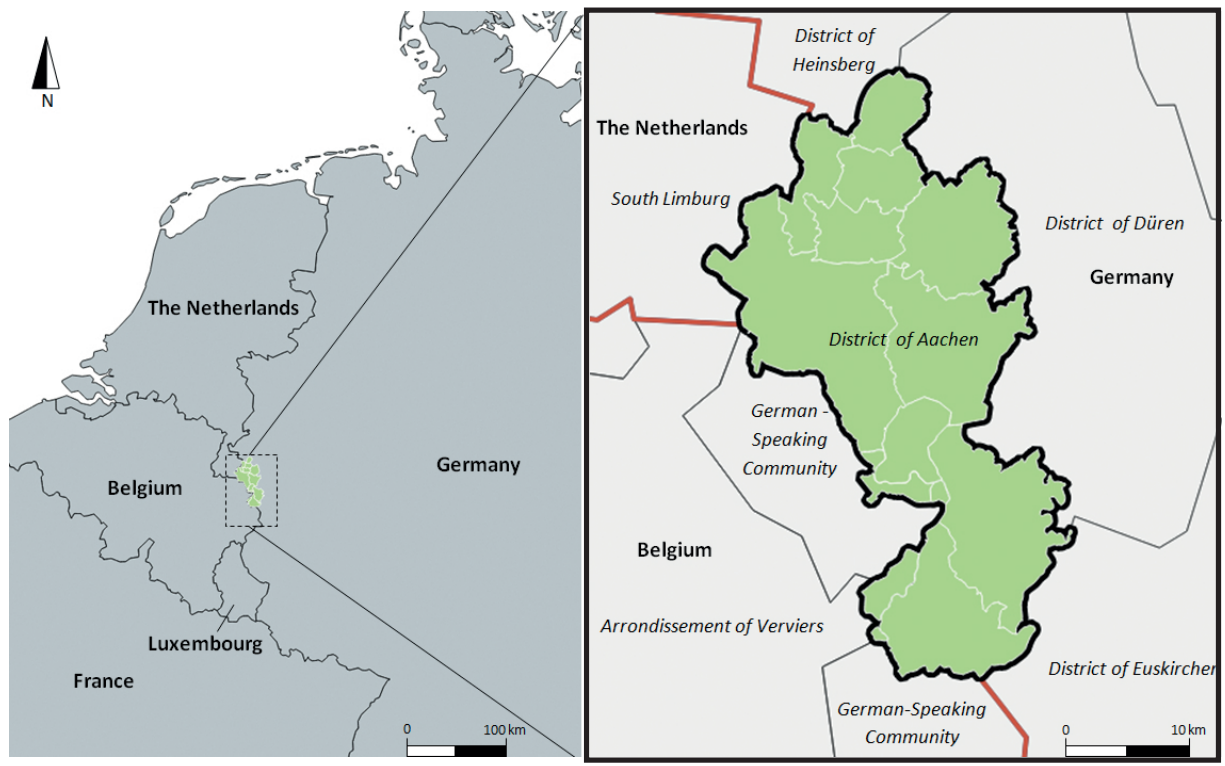

Figure 4.1: Location of the district of Aachen in Europe (left) and neighbouring territorial units (right) on NUTS 3 level (Source: Jenniches and Worrell, 2019, modified; map data sources: Eurostat, s.a.a)

Regarding its historic development, energy is deeply rooted in the regions' socioeconomic DNA. ${ }^{44}$ In the North of the region, black coal was exploited until 1997, when the last coal mine was closed (Bergbaumuseum Grube Anna, s.a.). Mining and fossil energy carriers still play a significant role in the region, which is part of the

44 The following description of the historical and current role of energy in the region is based on Jenniches and Worrell (2019). 
Rhenish lignite mining area. There is for example the lignite mine Inden ${ }^{45}$, whose resources are exploited for the generation of electricity in the lignite power plant Weisweiler which is scheduled to close in 2030 (RWE Power AG, s.a.). The work force of the lignite mine Inden and the power plant Weisweiler amounted to 2,672 employees in $2009^{46}$, demonstrating the regional economic significance of the lignite industry.

In terms of renewable energy (RE) developments, the region can be considered an early mover. Indeed, the Aachen model (German: Aachener Modell) of cost covering feed-in tariffs for renewable energies, which has been introduced in the 1990s in the region, is considered as the predecessor to the German feed-in tariffs regulation of the Renewable Energies Act (EEG) (Solarenergieförderverein e.V. et al., s.a.; Agentur für Erneuerbare Energien, 2014a).

By the end of 2017, a cumulative capacity of 201 MW of wind power has been installed in the region (Figure 4.2, left).

In a German-wide comparison, higher dynamics took place between the mid-1990s and 2003 in the district of Aachen. This may be explicable by the introduction of the feed-in tariff (Figure 4.2, right). After 2003, the dynamics in the region are almost comparable to the dynamics in Germany. In 2017, the region became more dynamic once more, which is explained by a change in the compensation system that nudges operators to install wind turbines until the end of 2018 (Section 4.3). ${ }^{47}$

45 The lignite mine is situated partly in the municipality of Eschweiler in the East of the region.

46 Employment effects of RWE Power AG have been evaluated by multiplying the employees of RWE Power AG in the lignite mine Inden and the power plant Weisweiler (1,600 employees according to RWE Power AG, 2009) by an average employment multiplier for the Rhenish lignite mining region (1.67 in 2009) according to EEFA (2010).

47 Nevertheless, large-scale developments like the installation of numerous wind plants in a wind power park that have - especially in small-scale regions - a significant impact on the development dynamics are installed in specific years and not developed constantly over time. Due to regulatory restrictions (zoning, availability of suitable space, etc. ), the development dynamics of wind power evolve differently than other RES technologies like for example PV which develops quite linearly in the region (see Jenniches and Worrell, 2019). 


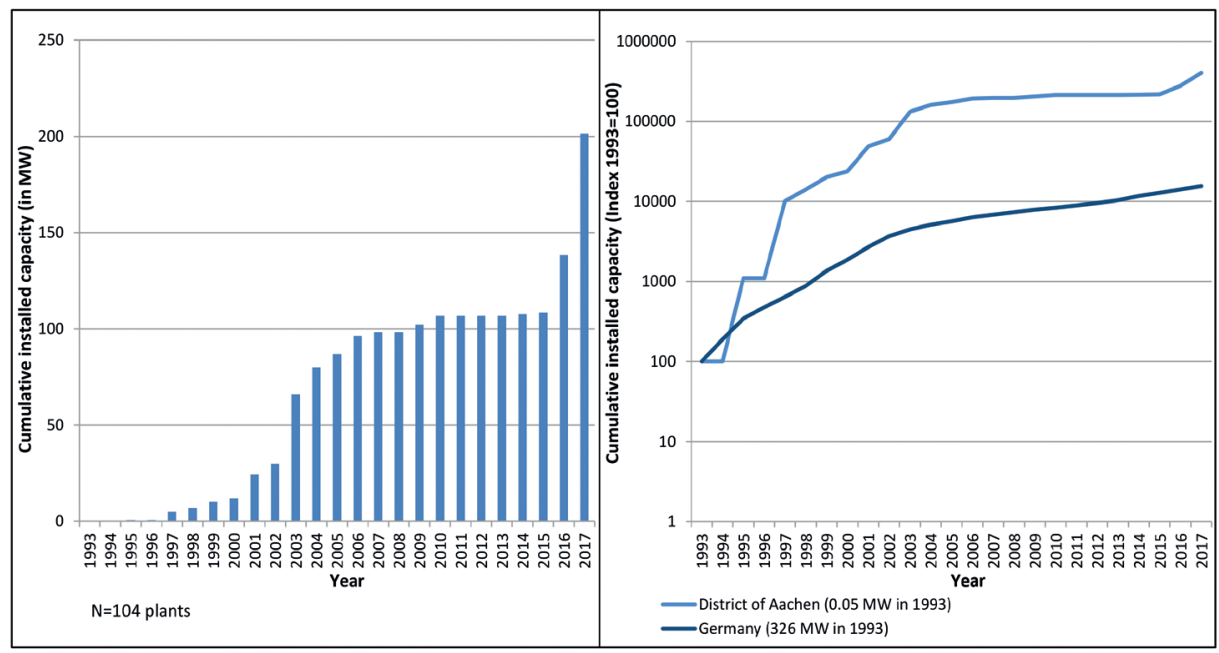

Figure 4.2: Cumulative installed capacity of wind power in the district of Aachen from 19932017 (left) (Source: render, 2016; Bundesnetzagentur, 2018) and wind power developments in comparison to Germany from 1993-201748 (right) (Source: data compilation by BMWi, 2016; Deutsche Windguard, in BWE, 2017)

\subsection{Regional economic impacts of wind power}

\subsubsection{Selection of an assessment methodology}

According to Jenniches (2018), most regional economic impact assessments of RES use employment ratios, Input-Output (IO) models, or supply chain analyses.

While the first method is not suitable to explore other factors besides employment, an IO model is an overall economic impact assessment tool (Leontieff 1936; 1951). It demonstrates the interactions of different industries in an economic system, illustrated in direct economic effects due to economic activities in an industry and indirect effects on suppliers of that industry. One of the challenges is the amount of data used to create an IO model. Unfortunately, regional IO tables (RIOTs) are not available for regions in Germany and would have to be derived from higher level (for example national) data (DIW, 2014a) or constructed by surveys (Coon et al., 1985). Nevertheless, statistical derivation from larger scale 10 models lacks precision on a small regional scale (BMVBS, 2011).

48 Due to issues of illustratability, a logarithmic scale has been used, which has to be taken into account when comparing the different developments in Germany and the district of Aachen. The plant installed in 1993 was a small plant of only 0.05 MW. Therefore, the changes from 1993 to 2017 occur much higher than in the case of Germany in the illustrated Figure 4.2 where an index has been used. 
Supply chain analyses also evaluate flows of goods and services, whereas the starting point of analysis is not the whole economic system, but a specific end product. For this product, the effects in different stages of the supply chain are evaluated..$^{49}$

In this sense, a supply chain analysis meet the evaluation's needs. ${ }^{50}$ Moreover, as Llesa et al. (2013) state, the advantage of analytical methodologies like the value chain approach is that that they are more easily to reproduce than IO models because the effects of significant variables are more comprehensible. This supports the validity of the results and makes a comparison of results easier (Section 4.3.5).

The supply chain analysis approach, which has been used by Hirschl et al. (2010) and Finus et al. (2013) in similar studies, which this paper follows methodologically, may be categorised as a bottom-up method to assess regional economic impacts. A detailed overview about the calculations is presented in Section 4.3.3. For a comparable study concerning the procedure in the district of Aachen see Jenniches and Worrell (2019) for PV. By applying this method, the regional value added according to the definition of Hirschl et al. (2010) and Bröcker et al. (2014) is assessed consisting of the components post tax revenues of enterprises, net income of employees, and regionally (i.e. municipally) raised taxes. Moreover, the number of full-time employees in the different industries is assessed in person years.

\subsubsection{Lifecycle analysis and estimation of economic activities carried out in the region}

In a first step, the activities concerning wind power developments and the activities that may be realistically taken over by regional enterprises are estimated.

Llera et al. (2013), followed by Jenniches and Worrell (2019) use 5 subsequent life cycle stages for the economic impacts assessment of RES which may be referred to as research and development (R\&D) (1), manufacturing (2), installation (3), operation

49 The costs of wind turbine maintenance during operation, for example, are interpreted as the material costs (or intermediate input) and the additional costs and benefits of the maintenance company. By applying industry specific statistics, it is possible to calculate the regional value added, generated by the activity maintenance. The costs of intermediate inputs are interpreted as material costs and as additional costs and benefits of the previous stage of the supply chain, which may be trading in this case. The material costs of trading are interpreted as the intermediate inputs, benefits and additional costs of component manufacturers and so on. For further explanation about supply chain analyses see Jenniches and Worrell (2019) or Hirschl et al. (2010).

50 For an evaluation of various regional economic impact assessment instruments see Breitschopf et al. (2011) or Jenniches (2018). 
and maintenance (O\&M) (4), and decommissioning (5). Figure 4.3 shows the activities in each lifecycle stage following literature in the field such as Bröcker et al. (2014), BMVBS (2011), or Deutsche Windguard (2013). Defining activities that can be taken over by regional enterprises is challenging because there is no statistical classification of the renewable energy industry (Statistisches Bundesamt, 2017). ${ }^{51}$

Dealing with this challenge, various industry statistics such as official and non-official sources (e.g. IHK Aachen, s.a.a; Cylex International S.N.C., s.a.) have been analysed to identify regional enterprises that are involved in the renewable energy industry. The analysis has been supported by an online survey (Jenniches and Worrell, 2019) and 21 enterprises involved in activities in the wind power market have been identified in the region. ${ }^{52}$ As it is difficult to provide a conservative estimate of specifically wind power related revenues of $R \& D$ and component manufacturing companies that are active in other business areas as well, the paper focuses on installation, operation and maintenance activities of wind power developments in the region as minimum economic impacts, nevertheless acknowledging the regional economic benefits of the local wind power industry.

To quantify the economic effects that depend on wind power developments in the region only, activities that are realistically carried out by regional enterprises are taken into account using enterprises located in the region from the regional enterprise analysis as a precondition, combined with literature values and field interviews for specific activities. In the installation stage, infrastructure, and foundation may fully be taken over by regional enterprises (Türck-Hövener, 2016).

It has been found that $55 \%$ of installed wind turbines in the region are operated by regional grid service companies, which is therefore assumed also to be the regional share of the activity grid connection. As some planning companies and wind turbine operators are located in the region, it is estimated, that all wind turbines may be planned and operated by regional enterprises. Due to the fact that insurances may be taken out by an internet contract or by a local insurance broker, a share of $50 \%$ for

51 For example, component suppliers of 'the wind power industry' are classified as manufacturers of the product categories rubber and plastic products, metal products, mechanical engineering, and electrical equipment (DIW, 2014a), whereas not every enterprise listed in, for example, the mechanical engineering industry is involved in the wind power market.

52 Four enterprises only involved in the small wind turbine market were excluded. Enterprises which are able to fulfill the activities funding, foundation and infrastructure, and insurance are also excluded in order not to sophisticate the amount of enterprises in the wind power market because wind power is considered as being only a peripheral business of these enterprises. 
insurances taken out by regional brokers is assumed. However, in case some activities may be taken over by external companies, an additional assessment with a $50 \%$ share of regional planning enterprises and operator $5^{53}$ and a zero share of regional insurance companies is calculated in order to provide a more conservative estimate and an idea of the impact of a change in the regional share on the economic effects (Section 4.3.4), which is also referred to in the discussion (Section 4.5).

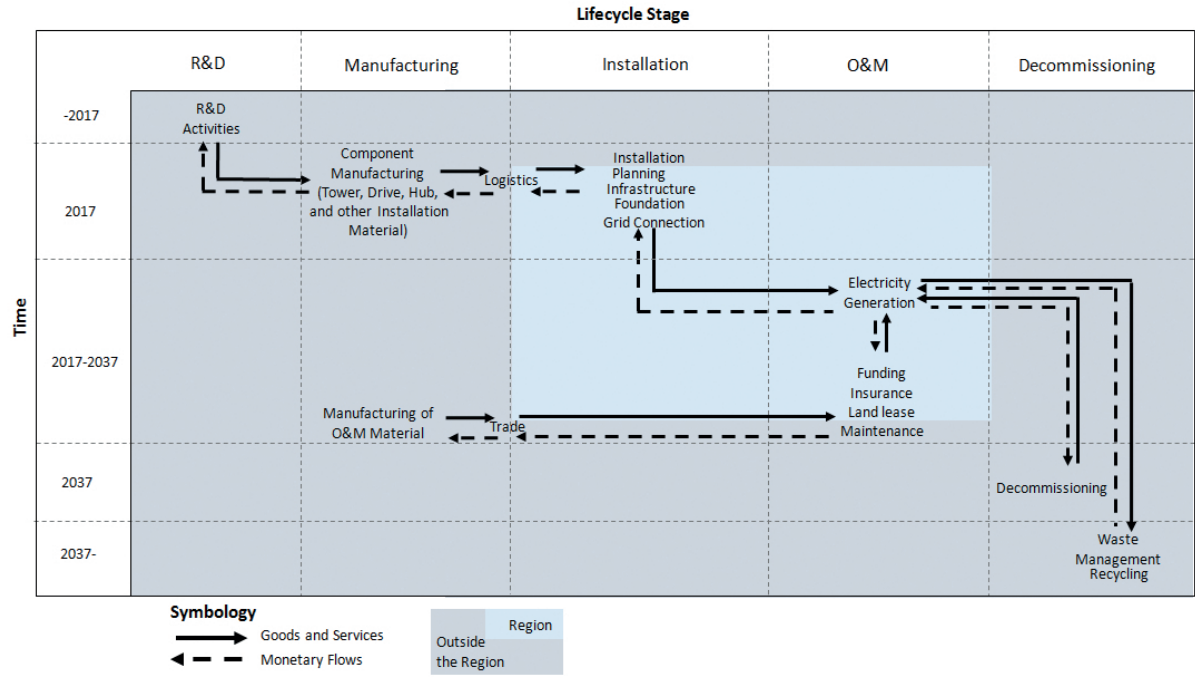

Figure 4.3: Lifecycle stages, time periods, activities and their spatial distribution regarding wind power developments in the district of Aachen

Whereas land lease may be naturally taken over by regional land owners, the paper follows BMVBS (2011) and uses a share of $45 \%$ of local credit institutes based on the analysis of local funding for RE projects. Other sources assume a higher share (such as $50 \%$ by Bröcker et al., 2014).

As depicted in Figure 4.3, the effects generated in the R\&D stage are assumed to occur before the installation in 2017. Moreover, manufacturing and installation are assumed to take place in 2017 with the exception of manufacturing of O\&M material, which takes place between 2017 and 2037. The operation and maintenance stage is assumed to last 20 years, which may be outlasted in single cases (Fraunhofer IWES,

53 In the calculation, the trade taxes of external operators flowing to the Aachen region, whose shares may vary in distinct cases (BWE, 2018), are not included in the calculation. 
2015). Decommissioning is therefore assumed to happen in 2037, whereas waste management and recycling may succeed 2037.

\subsubsection{Calculation of effects}

In 2017, one turbine with a capacity of $0.8 \mathrm{MW}$, four turbines in the power class between 2 and $3 \mathrm{MW}$ with a capacity of $10.8 \mathrm{MW}$, and 16 turbine between 3 and 4 $\mathrm{MW}$ with a cumulative capacity of $51.5 \mathrm{MW}$ respectively have been installed in the region. Therefore, the total installed capacity of the 21 wind turbines in 2017 is 63.1 MW (Figure 4.4). The estimated amount of electricity generated, based on location specific estimations for each wind turbine (Bundesnetzagentur, 2018), between 2017 and 2037 will be 3,901 GWh. ${ }^{54}$

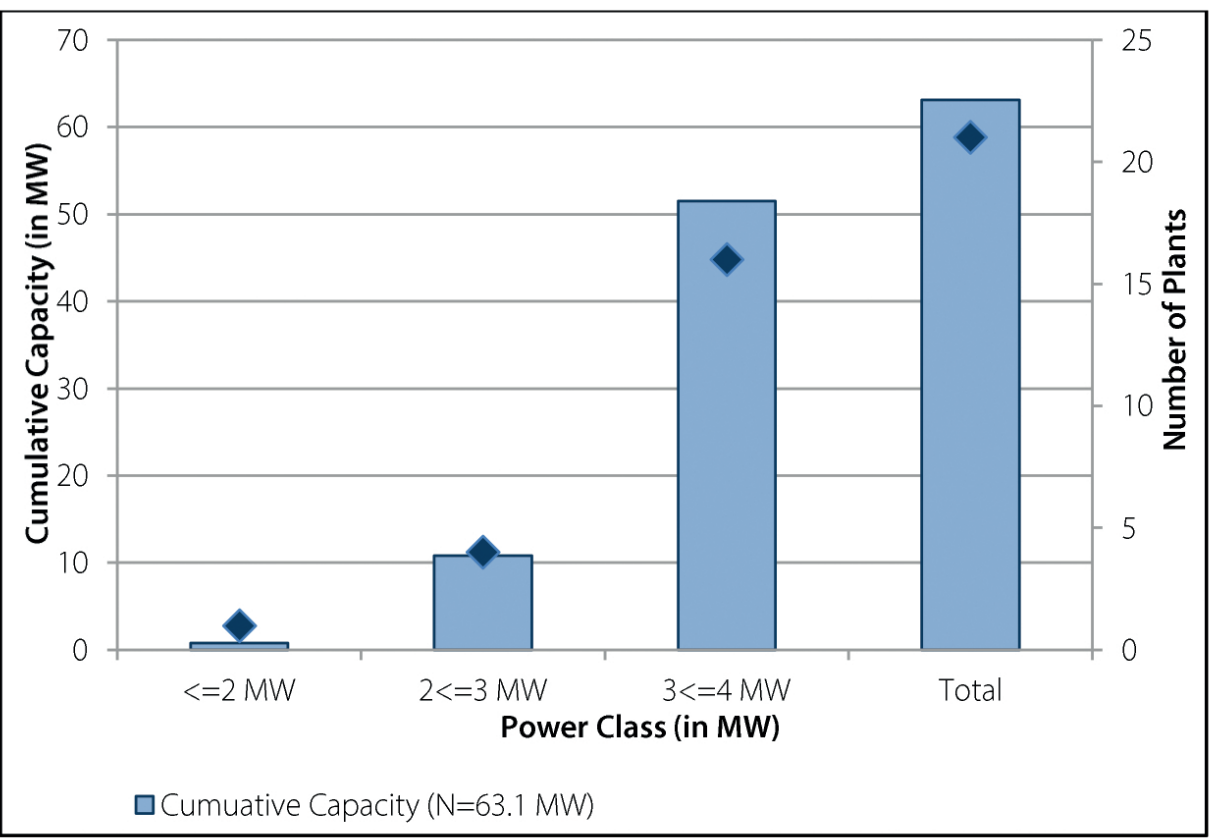

Figure 4.4: Number of wind turbine and total installed capacity of turbines installed in 2017 in the district of Aachen (Source: own calculations based on Bundesnetzagentur, 2018)

54 For 18 of the 21 wind turbines, the amount of electricity generated was taken from publicly available (Bundesnetzagentur, 2018) reports which, for every plant to be built, provide the expected harvest of the plant by taking into account the specific geographic conditions (FGW, 2017a). For three plants without data, a regional average value has been used. 
The individual capacities and further wind turbine specific characteristics are essential for the analysis of costs in the installation stage (Section 4.3.3.1). Moreover, the operation stage is analysed (Section 4.3.3.2), with a special emphasis on electricity generation (Section 4.3.3.3).

\subsubsection{Installation}

As the regional value added of wind power developments depends on wind turbine specific characteristics, an exemplary evaluation is illustrated for a Senvion 3.2M114 turbine with a capacity of $3.2 \mathrm{MW}$ and a hub height of $143 \mathrm{~m}$ that started operating in September 2017 in the region. These calculations have been made for every individual turbine in the region. Before calculating the regional economic impacts of wind power developments, a detailed cost analysis is elaborated. The installation costs are usually separated into the costs for the wind turbine and the additional wind turbine investment costs (e.g. planning, infrastructure). Costs for wind turbines depend on the power class and the hub height, whereas the latter is the main cost driver (Table 4.1). Turbine costs for the 3.2 MW turbine are $€ 3,936,000$ (with $€ 1,230 / \mathrm{kW}$ ).

Table 4.1: Costs and number of wind turbines (in brackets) in the Aachen district depending on hub heights and power classes ${ }^{55}$

Power Classes and Number of Wind Turbines

\begin{tabular}{llll} 
Hub Height (HH) & $\mathbf{0} \mathbf{M W}<\mathbf{P}<=\mathbf{2} \mathbf{M W}$ & $\mathbf{2} \mathbf{M W}<\mathbf{P}<=\mathbf{3} \mathbf{M W}$ & $\mathbf{3} \mathbf{M W}<\mathbf{P}<=\mathbf{4} \mathbf{M W}$ \\
\hline $\mathrm{HH}<=100 \mathrm{~m}$ & $€ 1,090 / \mathrm{kW}(1)$ & $€ 980 / \mathrm{kW}(1)$ & $€ 990 / \mathrm{kW}(0)$ \\
$100 \mathrm{~m}<\mathrm{HH}<=120 \mathrm{~m}$ & $€ 1,200 / \mathrm{kW}(0)$ & $€ 1,160 / \mathrm{kW}(0)$ & $€ 1,120 / \mathrm{kW}(0)$ \\
$120 \mathrm{~m}<\mathrm{HH}<=140 \mathrm{~m}$ & - & $€ 1,280 / \mathrm{kW}(2)$ & $€ 1,180 / \mathrm{kW}(9)$ \\
$140 \mathrm{~m}<\mathrm{HH}$ & - & $€ 1,380 / \mathrm{kW}(1)$ & $€ 1,230 / \mathrm{kW}(7)$ \\
\hline
\end{tabular}

(Source: Deutsche Windguard, 2013; Deutsche Windguard, 2015, modified; nominal values)

An estimation of the shares of sub components of the investment costs is depicted in Figure 4.5.

55 For plants above $2 \mathrm{MW}$, data refers to plants installed in 2016 and 2017 following Deutsche Windguard (2015). For plants below 2 MW, data refers to plants installed 2009-2013 following Deutsche Windguard (2013). 


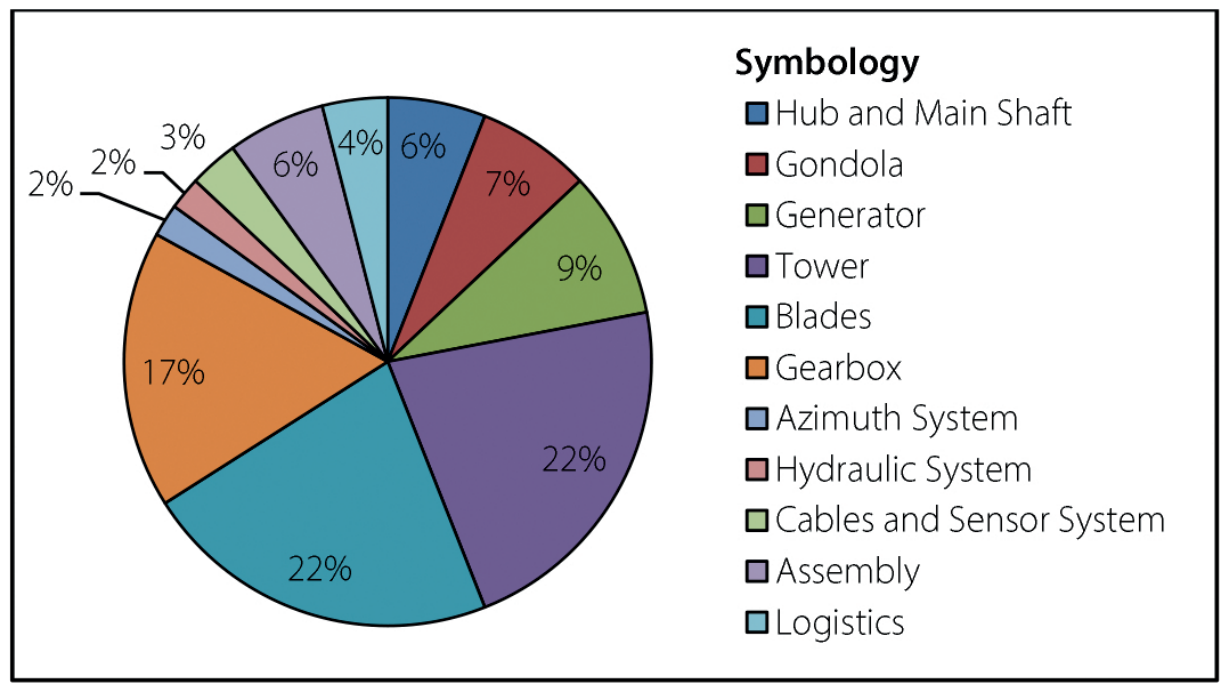

Figure 4.5: Components of investment costs (Source: Hirschl et al., 2010, modified)

As specific costs for 2017 were not available, costs of turbine that have been installed between 2009 and 2013 were used (see Table 4.2). The position other costs include costs like nature compensatory measures which occur when wind turbines have an impact on ecosystems or the landscape (Hau, 2017; Fachagentur Windenergie an Land, 2018). As the amount of compensatory measures are project specific (BUND and NABU, 2017), the costs for these measures cannot be properly disaggregated.

Table 4.2: Components of additional wind turbine investment costs

\begin{tabular}{lcc}
\hline Component & in $€ / \mathbf{k W}$ & in \% \\
\hline Foundation & 67 & 18 \\
Grid Connection & 73 & 20 \\
Infrastructure & 41 & 11 \\
Planning & 95 & 25 \\
Other Costs & 97 & 26 \\
\hline Total & $\mathbf{3 7 3}$ & $\mathbf{1 0 0}$ \\
\hline
\end{tabular}

(Source: Deutsche Windguard 2013, modified; nominal values)

The calculation of the regional value added is illustrated in Figure 4.6 for foundation and infrastructure for all wind turbines from 3 to $4 \mathrm{MW}$. 


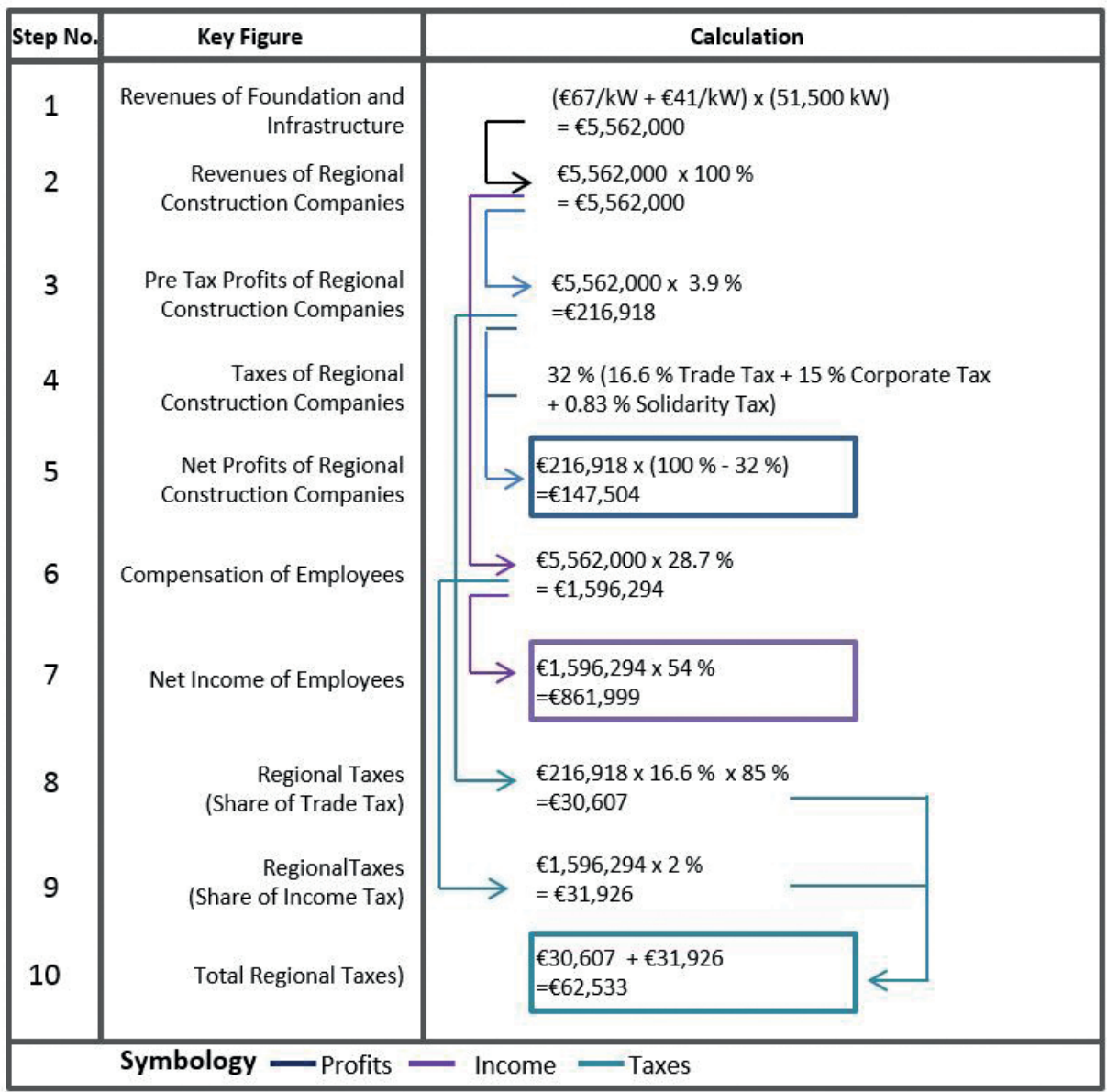

Figure 4.6: Calculation of regional value added of foundation and infrastructure of wind turbines from 3-4 MW, installed in the Aachen district in 2017 (nominal values) ${ }^{56}$

The first step consists of multiplying the costs for foundation and infrastructure (Table 4.2) by the cumulative capacity of the wind turbines (1). Due to the fact, that these activities are usually taken over by regional enterprises (Figure 4.3 and TürckHövener, 2016), a share of $100 \%$ of regional enterprises is assumed (2). These values are multiplied by the pre-tax profits as a share of the revenues of the construction industry, derived from industry specific statistics (Deutsche Bundesbank, s.a.b). ${ }^{57}$ After subtracting trade taxes, corporate taxes, and the solidarity tax (4), one is able to calculate the net profits of regional construction companies as a first component

56 The results vary slightly from the results in Table 4.5 due to rounding effects.

57 For financial institutions in the O\&M stage, statistics of Deutsche Bundesbank (s.a.a) are used 
of the regional value added (5). ${ }^{58}$ The compensation of the employees is calculated by multiplying the revenues of the regional construction enterprises by an industry specific value (6). Integrating taxes (Bundesministerium der Finanzen, 2016) and social insurance costs (Bundesministerium der Justiz und für Verbraucherschutz, s.a.c-g, Bundesministerium für Arbeit und Soziales, 2015), the net income of employees can be illustrated (7). In a next step, regional taxes are evaluated, consisting of the regional share of the trade tax (8) and the share of the income tax of employees (9). To conclude, the total value added concerning the foundation and infrastructure of the 3 to $4 \mathrm{MW}$ wind turbines in the district of Aachen is $€ 1,072,036$. The employment effects are calculated by dividing the net income for employees (Destatis, 2016), which yields 36 jobs in the construction industry in 2017 or 36 person years. These calculations have been processed for all activities in the installation stage (Table 4.5).

\subsubsection{Operation and maintenance}

For O\&M costs, the latest data for Germany (Deutsche Windguard, 2013) is used. Because the costs vary during the first (year 1-10) and the second period (year 11-20) of operation due to different conditions (for instance maintenance costs are typically higher in the second term), average costs for the whole operation period (Table 4.3) are calculated. Regarding land lease, the paper follows Hirschl et al. (2010), who assumed a share of $80 \%$ of private landlords and $20 \%$ of the land owned by the municipality.

Table 4.3: Nominal O\&M costs, depending on time periods and components for wind turbines installed between 2009 and 2013

\begin{tabular}{lllll}
\hline Component & $\begin{array}{l}\text { Year 1-10 } \\
\boldsymbol{\epsilon} / \mathbf{M W h}\end{array}$ & $\begin{array}{l}\text { Year 11-20 } \\
\boldsymbol{\epsilon} / \mathbf{M W h}\end{array}$ & $\begin{array}{l}\text { Year 1-20 } \boldsymbol{\epsilon} / \\
\mathbf{M W h}\end{array}$ & $\begin{array}{l}\text { Year 1-20 } \\
\boldsymbol{\epsilon} / \mathbf{k W h}\end{array}$ \\
\hline Maintenance & 10.5 & 14.7 & 12.6 & 0.0126 \\
\hline $\begin{array}{l}\text { Land Lease } \\
\text { Operation and }\end{array}$ & 5.3 & 5.1 & 5.2 & 0.0052 \\
$\begin{array}{l}\text { Management Costs } \\
\text { Insurance }\end{array}$ & 4.1 & 3.6 & 3.85 & 0.00385 \\
Reserve Assets & 1.2 & 0.7 & 0.95 & 0.00095 \\
Other Costs & 2 & 1.4 & 1.2 & 0.0012 \\
\hline Total & 24.1 & 1.3 & 1.65 & 0.00165 \\
\hline
\end{tabular}

(Source: Deutsche Windguard, 2013, modified)

58 Solidarity tax was introduced in the 1990s to finance the German reunification (Bundesministerium der Justiz und für Verbraucherschutz, s.a.b). 
Funding conditions are based on Deutsche Windguard (2015), verified by an interview with the German Wind Energy Association (BWE). They assume a 2.5\% interest rate and an $85 \%$ share of external capital. A 10 year credit period is considered, comparable to the conditions provided by $\mathrm{KfW}$, the most important financial institution in the German renewable energy market (KfW, 2015; Papendieck, 2015).

Moreover, electricity marketing costs of $€ 0.002 / \mathrm{kWh}$ (Deutsche Windguard, 2015) are included which results in operation costs of $€ 0.02745 / \mathrm{kWh}$. Following the method depicted in Figure 4.6, one can estimate the regional value added for operation and maintenance activities generated between 2017 and 2037.

\subsubsection{Electricity generation}

Since the introduction of the EEG 2017, compensations for wind power electricity are determined by a tender process. However, in a transitional arrangement, turbines which have obtained planning permission before 2017 and start operating before the end of 2018, still have the right of a compensation by a general feedin tariff (Bundesnetzagentur, 2017b). As the highest bid that awarded a contract in the second tender process in 2017 (4.29 c/kWh) has been below the feed-in tariffs (Table 4.4), it is assumed that operators may make use of the transition arrangement (Bundesnetzagentur, 2017c).

Table 4.4: Feed-in tariff of wind turbines in the district of Aachen, starting to operate in September 2017

\begin{tabular}{ll}
\hline Component of feed-in tariff & In c/kWh \\
\hline Higher feed-in tariff (first 5 years) & 7.47 \\
Lower feed-in tariff (last 15 years) & 3.97 \\
\hline
\end{tabular}

(Source: Netztransparenz, 2018; nominal values)

The feed-in tariff for wind turbines in the transition arrangement consists of a higher feed-in tariff for the first five years of the operation period and a lower feed-in tariff for the last fifteen years of the operation time (Table 4.4).

The location specific harvest of a wind turbine has to be related to the harvest of that specific turbine type in a reference location, which may lead to an extension of the higher feed-in tariff period (FGW, 2017b). It is estimated that the exemplary 3.2 MW turbine generates $49.8 \mathrm{GWh}$ in the first five years (Bundesnetzagentur, 2018) which 
is $92.8 \%$ of the harvest of the turbine in the reference location (Bundesnetzagentur, 2018).

The following formula is used to calculate the prolongation of the higher feed-in tariff period according the German renewable energy act (EEG). For a $92.8 \%$ reference location $(x=92.8)$, the higher feed-in tariff paid would be provided for 14.9 years in that case (Equation 4.1).

$$
[(130-x) / 0.36=t \text { (months) }] / 12+[(100-x) / 0.48=t(\text { months })] / 12+5(\text { years })=t
$$

$\mathrm{x}=$ reference location

Equation 4.1: Prolongation of the higher feed-in tariff period (Source: Dağaşan et al., 2014, modified)

The average feed-in tariff for twenty years is calculated by using the following Equation 4.2 , according to the EEG.

$$
\left[\left(t_{1} / 20\right) \times r_{1}(c / k W h)\right]+\left[\left(t_{2} / 20\right) \times r_{2}(c / k W h)\right]=r_{a}(c / k W h)
$$

$\mathrm{t}_{1}$ higher feed-in tariff period (in years)

$\mathrm{t}_{2}$ lower feed-in tariff period

$r_{1}$ feed-in tariff during the higher feed-in tariff period

$r_{2}$ feed-in tariff during the lower feed-in tariff period

$r_{a}$ average feed-in tariff

Equation 4.2: Average feed-in tariff for twenty years (Source: BMU, 2013, modified)

Inserting the specific feed-in tariff periods $\left(t_{1}=14.9, t_{2}=5.1\right)$ and the feed-in tariff $\left(r_{1}=7.47\right.$, $r_{2}=3.97$ ) for the exemplary turbine, starting to operate in September 2017 in the district of Aachen, leads to an average feed-in tariff of $6.57 \mathrm{c} / \mathrm{kWh}$ during the 20 years of turbine operation.

Figure 4.7 shows the calculation of regional profits and taxes of electricity generation for a 3.2 MW wind turbine resulting in revenues of $€ 1,005,000$ and regional taxes of $€ 285,000$. 


\begin{tabular}{|c|c|c|}
\hline Step No. & Key Figure & Calculation \\
\hline 1 & Electricity Generation & $\begin{array}{c}9,960,000 \mathrm{kWh} \times 20 \mathrm{a} \\
-=199,200,000 \mathrm{kWh}\end{array}$ \\
\hline 2 & Revenue Feed-in-Tariff & $\begin{aligned} \rightarrow & 199,200,000 \mathrm{kWh} \times € 0.0657 / \mathrm{kWh} \\
& =€ 13,087,440\end{aligned}$ \\
\hline 3 & Wind Plant Costs & $\begin{array}{l}3,200 \mathrm{~kW} \times € 1,230 / \mathrm{kW} \\
=€ 3,936,000\end{array}$ \\
\hline 4 & Installation Costs & $\begin{array}{l}(3,200 \mathrm{~kW} \times € 373 / \mathrm{kW}) \\
=€ 1,193,600\end{array}$ \\
\hline 5 & Operation Costs & $\begin{array}{l}\longrightarrow 199,200,000 \mathrm{kWh} x € 0.02745 / \mathrm{kWh} \\
=€ 5,468,040+€ 621,705 \text { (Funding } \\
\text { Costs) }=€ 6,089,745\end{array}$ \\
\hline 6 & $\begin{array}{r}\text { Profit } \\
\text { Trade Taxes }\end{array}$ & $\begin{aligned} &=€ 1,868,095 \\
&(€ 1,868,095-€ 490,000) \times 16.6 \% \\
&==€ 228,764\end{aligned}$ \\
\hline 8 & Income Taxes & $\begin{aligned} & € 1,868,095 \times 42 \%-13.3 \% x \\
& (€ 1,868,095-€ 490,000) \\
= & =€ 601,313\end{aligned}$ \\
\hline 9 & Solidarity Tax & $\begin{aligned} & € 01,313 \times 5.5 \% \\
& =€ 33,072\end{aligned}$ \\
\hline 10 & Profit after Taxes & $\longrightarrow € 1,004,946$ \\
\hline 11 & Municipal Taxes & $\begin{aligned} & 85 \% \times 228,764+€ 601,313 \times 15 \% \\
\longrightarrow & =€ 284,646\end{aligned}$ \\
\hline
\end{tabular}

Figure 4.7: Schematic illustration of the value added effects of electricity generation (excl. income) of the exemplary 3.2 MW turbine installed in 2017 in the district of Aachen (nominal values)

As turbine operators will have to take part in the tender process from 2018 onwards, it is evaluated whether turbine operators in the Aachen region would be able to compete with a bid of compensation under $4.29 \mathrm{c} / \mathrm{kWh}$ which was the maximum bid in the second round in 2017. As the bid refers to a $100 \%$ reference location in the EEG 2017, the actual compensation is calculated by taking into account the location of the turbine. Following BWE (2016a), this leads to a compensation of $4.51 \mathrm{c} / \mathrm{kWh}$.

Evaluating the profitability of investments for operators, the levelized cost of electricity (LCOE) is calculated following Kost et al. (2013) to evaluate the minimum bid for turbines in the Aachen region (Equation 4.3). 


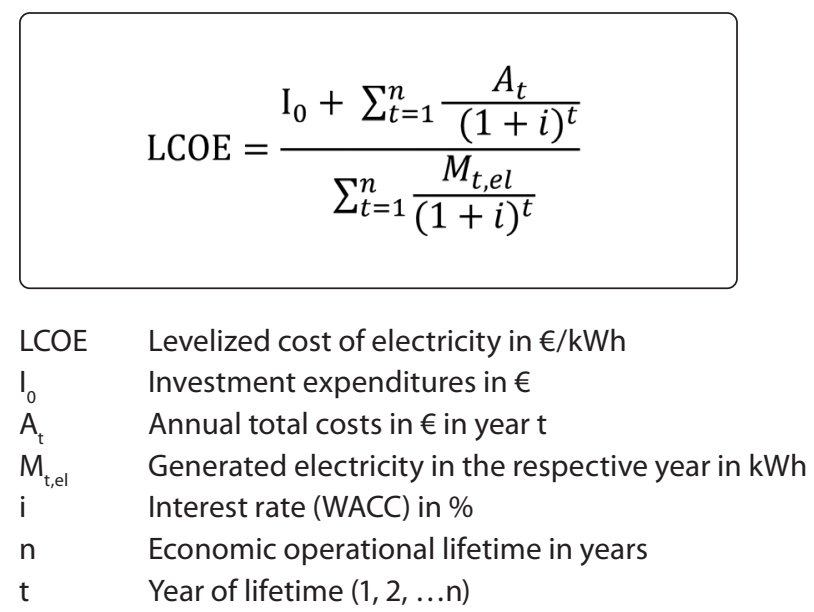

Equation 4.3: Calculation of the LCOE (Source: Kost et al., 2013, modified)

Assuming that the interest rate is based on the Weighted Average Cost of Capital (WACC) to account for the operator's equity and debt. As the equity capital cost, a rate of $9 \%$ has been assumed (Kost et al., 2013). The LCOE and therefore the minimum bid for the turbine would be $6.36 \mathrm{c} / \mathrm{kWh}$. To conclude, under these assumptions, wind turbines in the Aachen region cannot compete with bids in the tender process, considering future bids will be at a similar level as in 2017. However, the positive effects of wind power may still exceed other electricity generation sources as discussed in the conclusion (Section 4.5).

\subsubsection{Results}

Table 4.5 illustrates the final results for specific industries, including a scenario with a lower share of regional enterprises for the activities planning, insurance and electricity generation. In the assumed baseline scenario, all effects may be added up to $€ 32,863,000$ of profits, $€ 10,362,000$ of income, and $€ 7,601,000$ of taxes resulting in a value added of $€ 50,825,000$ and employment effects of 309 person years. Municipalities profit not only from taxes, but also from income from public land lease $(€ 3,350,000)$, which yields $€ 10,951,000$ of municipal profits in total (Table 4.5). For 2017 only, the value added is $€ 5.9$ million $^{59}$.

59 The value added of $€ 5.9$ million is $0.13 \%$ of the nationwide value added in 2012 (Hirschl et al., 2015). The employment effects in 2017 are 101 person years, accounting for $0.27 \%$ of total employment in the German wind power industry (Hirschl et al., 2015). The 2012 data includes both onshore- and offshore wind power data as well as the economic effects of wind turbine manufacturing. Noted, however the installed capacity in Germany 2017 increased by 64\% since 2012. Therefore, the regional economic effects in 2017 may be lower in comparison to the national effects in Germany in 2012. 
The total effects during the construction and installation stage are approximately $€ 3,602,000$ ( $€ 57,000 / \mathrm{MW}$ ), whereas $€ 734,000$ are profits, $€ 2,590,000$ incomes and $€ 278,000$ municipal taxes. Employment effects are 90 jobs (1.4/MW) in 2017 (or 90 person years). In the operation stage (2017-2037), land lease, insurance, and financing lead to regional economic effects of $€ 13,878,000$ ( $€ 220,000 / \mathrm{MW}$ ) and 19 person years $(0.3 / \mathrm{MW}$ ). The effects generated by electricity generation are $€ 33,344,000$ ( $€ 8.5$ per MWh electricity generated) and 200 person years ( $0.05 / \mathrm{GWh})$.

The effects of electricity generation account for $66 \%$ of the total effects. Land lease, making $€ 12,508,000$ or $25 \%$ of the total effects, are the second highest position although nearly three times smaller than the effects, generated by electricity generation. Other relatively high effects occur for planning and documentation $(€ 2,020,000)$, funding $(€ 1,245,000)$, and foundation and infrastructure $(€ 1,312,000)$.

Most employment effects arise for wind turbine management in the activity electricity generation. Other relatively high effects account for planning (42 person years) and construction companies (44 person years). Even though planning companies' employees' income $(€ 1,413,000)$ is significantly higher than incomes of the activity construction $(€ 1,056,000)$, the employment effects are only slightly higher due to a higher average income in the planning industry.

Municipal taxes for wind power developments in 2017 are $€ 645,000$ in 2017 and amount to $0.13 \%$ of the total share of income and trade tax arising in the district of Aachen in 2016 (IT.NRW, 2018). It should be noted, however, that corporate taxes are not included. Total taxes of these wind turbines from 2017-2037 are $€ 7,601,000$ and provide for 1.5\% of the regional income and trade tax in 2016.

The total effects of wind turbines installed in 2017 (309 person years) make 0.15\% of total employees in the district of Aachen by the end of 2016 (Bundesagentur für Arbeit, 2018).

In the lower share of regional enterprises-scenario, a 50\% share of regional planning enterprises would lead to a reduced value added of $€ 1,010,000$ and a zero share of regional insurance companies to a reduction of $€ 126,000$. If only half of the wind power operators were situated in the Aachen district, this would imply a value added of only $€ 16,672,000$ for the activity electricity generation, and a $32 \%$ reduction of the total value added of wind power. The lower scenario would lead to a total value added of $€ 33,017,000$ and employment effects of 185 person years. 
Due to the German and European merit-order effect ${ }^{60}$ of wind power, a volatile energy carrier, substitutes mainly electricity generated by coal and gas (Section 4.4.2), as there are no large storage capacities. This has no significant impact on the regional energy system heavily relying on lignite, because no large coal or gas power plants are located in the region. However, as it is expected that lignite mine will be closed by 2030, the employment potentials of renewables should be compared to the fossil fuels in the region (Section 4.5).

\subsubsection{Comparison of the results with existing studies}

To analyse regional differences of economic impacts and to identify factors affecting the results of regional economic analyses, the results are compared to other German studies in the field that use a similar methodology (Table 4.6). ${ }^{61}$ Enabling a comparison to international studies, economic effects of wind power developments outside of Germany are as well illustrated. The German studies cover NUTS levels from local administrative units (LAU), which are municipalities, to NUTS 1 regions, which are federal states. The different sizes of regions affect the results because, for example, Bröcker et al. (2014) studied the impact of wind power on a federal state level where higher shares of taxes occur than on a municipal scale because of the German tax distribution scheme.

All wind turbines have the same lifetime of 20 years and capacities range from 1.6 to 3.2 MW. As most authors focus on a single power class, solely the effects of wind turbines with capacities between 3 and $4 \mathrm{MW}$ as the predominantly installed power class are taken into account in the results for the Aachen district. To overcome differences between calculations, data is aggregated making the results comparable to the results in the defined lifecycle stages in this paper, which is illustrated in the following. ${ }^{62}$

60 The merit-order effect may be defined as: "The merit order of production ranks the available power plants in ascending order according to their marginal costs of production. The plants with the lowest marginal costs deliver power most of the time and are dispatched first. The higher the demand rises, the more expensive plants are utili[s]ed. Power price corresponds to the marginal costs of the last power plant that is still needed to cover demand"Böckers et al. (2013:2,3)

61 A similar comparison has been conducted by Jenniches and Worrell (2019) for PV.

62 For the installation stage, Bröcker et al. (2014) and Hirschl et al. (2010) present the aggregated costs of manufacturing and the assembly of the plant. 


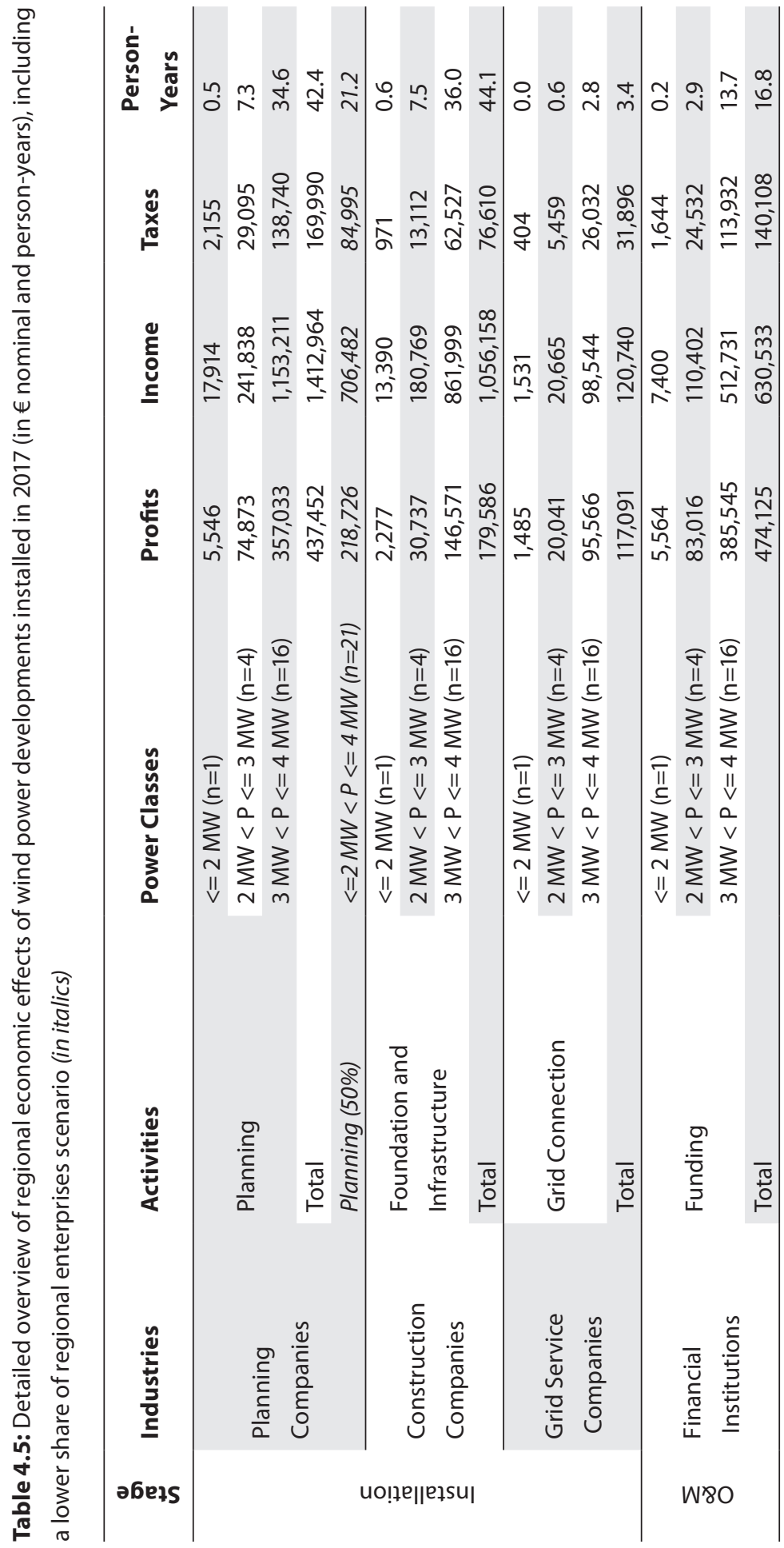


Regional Economic and Environmental Impacts of Wind Power Developments

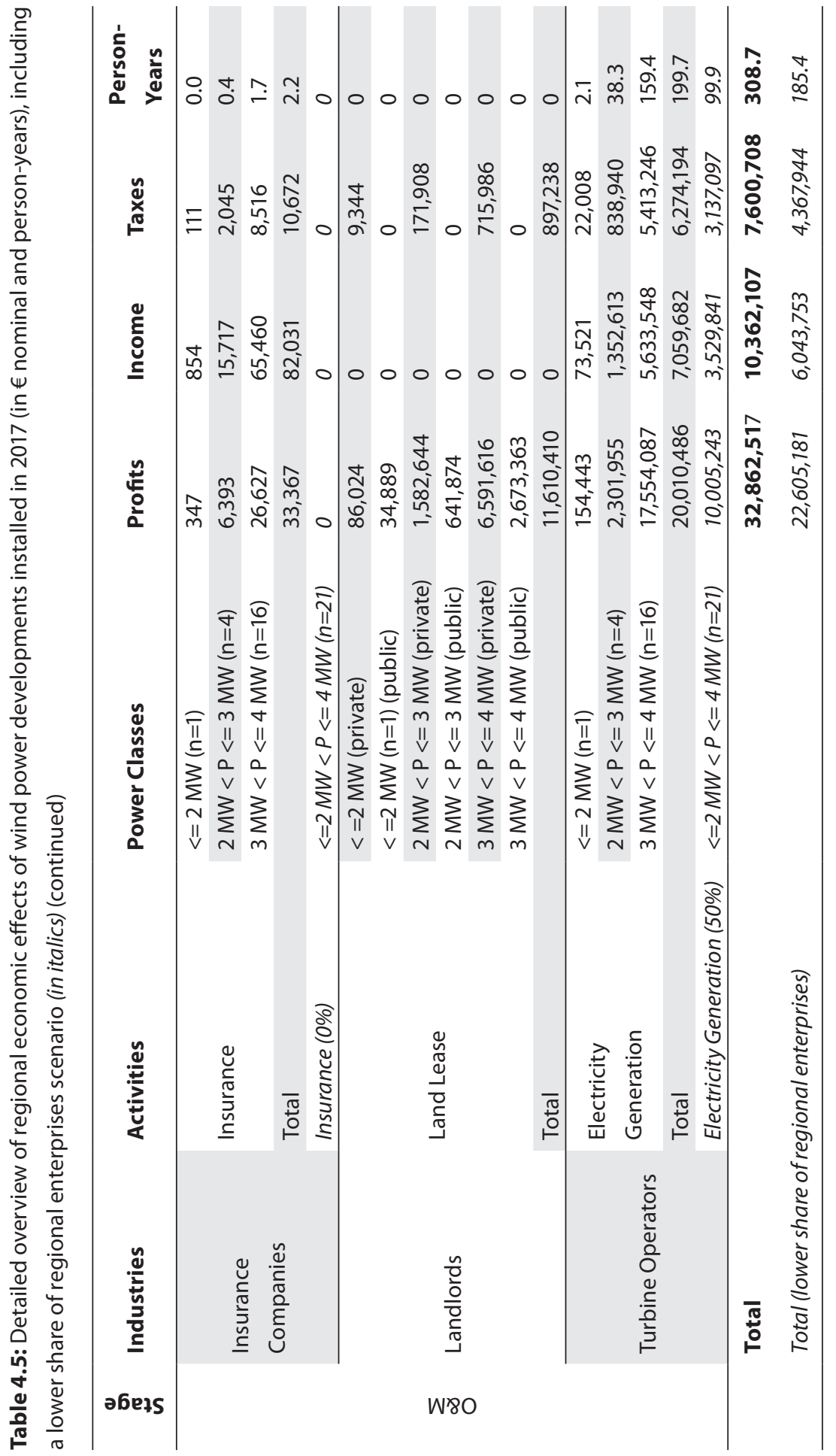


Chapter 4

Table 4.6: Comparison of regional economic effects of wind power developments (nominal values) $)^{63}$

\begin{tabular}{|c|c|c|c|c|c|c|}
\hline \multirow[b]{2}{*}{ Country } & \multirow[b]{2}{*}{ Region } & \multirow[b]{2}{*}{$\begin{array}{l}\text { Spatial } \\
\text { Level }\end{array}$} & \multirow[b]{2}{*}{$\begin{array}{l}\text { Installation } \\
€ / \mathbf{k W}\end{array}$} & \multirow{2}{*}{$\begin{array}{l}\text { Operation } \\
\text { Operation } \\
€ / \mathbf{k W}\end{array}$} & \multirow[b]{2}{*}{$\begin{array}{l}\text { Electricity } \\
\text { Generation } \\
€ / \mathbf{k W}\end{array}$} & \multirow[b]{2}{*}{ Source } \\
\hline & & & & & & \\
\hline Germany & Trier & NUTS 2 & - & 684 & 435 & $\begin{array}{l}\text { BMVBS } \\
(2011)\end{array}$ \\
\hline Germany & $\begin{array}{l}\text { Nord- } \\
\text { schwarzwald }\end{array}$ & $\begin{array}{l}\text { Four } \\
\text { aggregated } \\
\text { NUTS } 3 \\
\text { regions }\end{array}$ & - & 684 & 435 & $\begin{array}{l}\text { BMVBS } \\
(2011)\end{array}$ \\
\hline Germany & $\begin{array}{l}\text { Städteregion } \\
\text { Aachen }\end{array}$ & NUTS 3 & 57 & 215 & 555 & $\begin{array}{l}\text { This } \\
\text { Paper }\end{array}$ \\
\hline Germany & $\begin{array}{l}\text { Munici- } \\
\text { palities in } \\
\text { Germany in } \\
\text { general }\end{array}$ & LAU 2 & 121 & 388 & 700 & $\begin{array}{l}\text { Hirschl } \\
\text { et al. } \\
(2010)\end{array}$ \\
\hline Germany & Hannover & NUTS 3 & - & 692 & 669 & $\begin{array}{l}\text { BMVBS } \\
(2011)\end{array}$ \\
\hline Germany & Friesland & NUTS 3 & - & 698 & 873 & $\begin{array}{l}\text { BMVBS } \\
(2011)\end{array}$ \\
\hline Germany & $\begin{array}{l}\text { Schleswig- } \\
\text { Holstein }\end{array}$ & NUTS 1 & 77 & 872 & 1,175 & $\begin{array}{l}\text { Bröcker } \\
\text { et al. } \\
\text { (2014) }\end{array}$ \\
\hline US & Texas & State & 30 & 37 & - & $\begin{array}{l}\text { Slattery } \\
\text { et al. } \\
\text { (2011) }\end{array}$ \\
\hline US & Washington & State & 33 & 117 & - & $\begin{array}{l}\text { Heavner } \\
\text { et al. } \\
(2003)\end{array}$ \\
\hline US & Utah & State & 95 & 88 & - & $\begin{array}{l}\text { Ratliff et } \\
\text { al. (2010) }\end{array}$ \\
\hline
\end{tabular}

63 Values have been converted into $€$ by relying on Deutsche Bundesbank (2017) 
Table 4.6: Comparison of regional economic effects of wind power developments (nominal values) (continued)

\begin{tabular}{lllllll}
\hline Country & Region & $\begin{array}{l}\text { Spatial } \\
\text { Level }\end{array}$ & $\begin{array}{l}\text { Installation } \\
\boldsymbol{\epsilon} / \mathbf{k W}\end{array}$ & $\begin{array}{l}\text { Operation } \\
\text { Operation } \\
\boldsymbol{\epsilon} / \mathbf{k W}\end{array}$ & $\begin{array}{l}\text { Electricity } \\
\text { Generation } \\
\boldsymbol{\epsilon / k W}\end{array}$ & Source \\
\hline US & Colorado & State & 19 & 172 & - & $\begin{array}{l}\text { Madsen } \\
\text { et al. } \\
\text { (2002) }\end{array}$ \\
US & $\begin{array}{llllll}\text { Livingston } \\
\text { County }\end{array}$ & County & 55 & 146 & - & $\begin{array}{l}\text { Loomis } \\
\text { (s.a.) }\end{array}$ \\
\hline
\end{tabular}

In the comparison of the value added of the installation stage, similar values are presented by Bröcker et al. (2014), and Hirschl et al. (2010). Differences to this paper are explicable first because of the installation which is taken over by regional enterprises in Bröcker et al. (2014) ${ }^{64}$ and Hirschl et al. (2010). Moreover, Bröcker et al. (2014) asses the value added of other costs and costs for nature compensatory measures, whereas the latter is assessed by Hirschl et al. (2010) as well, which was not possible in this paper (Section 4.3.3.1). Hirschl et al. (2010) integrate the value added of logistics as well which partially explains higher results of Hirschl et al. (2010).

In summary, it can be concluded that the value added of the installation stage mostly depends on the activities and regional share of enterprises which are taken in the calculations into account.

The highest values in the operation stage are presented by Bröcker et al. (2014). This is mainly due to methodological differences, leading to a relatively high value added for the activity funding (more than 3 times higher than in Hirschl et al., 2010).

The results of Bröcker et al. (2014) and Hirschl et al. (2010) include the value added of maintenance activities, which and are fully carried out by regional enterprises.

Costs for land lease are approximately 1.5 times higher in Bröcker et al. (2014) than in Hirschl et al. (2010) because of higher benefits in the North German region Schleswig-

64 This is especially characteristic for North German regions, where lots of enterprises of the German wind power industry are located (BWE, 2016b) (e.g. Enercon and Nordex which account for $51 \%$ of the installed capacity in the German wind power market according to BWE, 2015). 
Holstein with excellent potentials for wind power, whereas Hirschl et al. (2010) assess the overall situation in Germany.

Since BMVBS (2011) did not distinguish between profits of enterprises and income of employees, illustrating the sum of the two positions without taking other costs and taxes of enterprises into account and define the costs for borrowed capital directly as value added, which makes half of the value added in the operation stage, their values for operation are naturally higher than in Hirschl et al. (2010), where approximately 1/3 of the value added in the operation stage relies on funding. Therefore, BMVBS (2011) may overestimate the economic benefits of the operation stage.

The differences between Hirschl et al. (2010) and this paper's results are mainly due to the activities maintenance and disassembling that are taken over by regional enterprises in Hirschl et al. (2010), whereas in the Aachen region no regional enterprises involved in that activity has been identified. This is also the case for the position funding, where a $45 \%$ share of regional banks of has been assumed (Section 4.3.2). Secondly, a lower interest rate has been determined, whereas Hirschl et al. (2010) calculate the total regional potential by assuming a $100 \%$ share of regional banks and used different statistics calculating the value added for banks.

For the activity electricity generation, results range between $€ 435$ and $€ 1,175$ per $\mathrm{kW}$. These differences are partly explicable by geographical differences and wind potentials, ranging from 1,936 full load hours (Trier in BMVBS, 2011) to 2,780 h (Schleswig-Holstein in Bröcker et al., 2014), and 3,072 $\mathrm{h}$ in the Aachen region. ${ }^{65}$ Further determining factors are the decrease in feed-in tariffs, since the feed-in tariff for operators in the Aachen region is only $80 \%$ of the tariff in Schleswig-Holstein (Bröcker et al., 2014) in 2014 and a relatively high income tax rate for operators in this paper that can be regarded as a conservative estimation which may eventually underestimate the potential effects for operators.

In summary, along methodological differences, the availability of regional enterprises, the location which determines the electricity generation potentials and decreasing feed-in tariffs for wind turbines can be rated as the significant variables influencing the impact assessment results.

65 The additional full load hours of plants in the Aachen region in comparison to plants in the coastal region Schleswig-Holstein are explicable by more efficient, modern power plants. 
In non-German studies, economic effects range from $€ 19$ to $€ 95$ per kW in the installation stage and from $€ 37$ to $€ 172$ per $\mathrm{kW}$ in the operation stage. Lower values in comparison to studies in Germany result mainly from methodological differences, since the studies use different costs and another definition and calculation of the regional value added as in this paper. ${ }^{66}$ For example, annual land lease is calculated with $€ 2,263$ per MW by Ratliff et al. (2010), whereas annual land lease in SchleswigHolstein is more than six times higher (€14,400/MW) (Bröcker et al., 2014).

\subsection{Impacts of wind power on GHG emissions and air pollution}

\subsubsection{Methodology to assess the impacts of wind power on GHG emissions and air pollution}

When assessing the avoided GHG emissions for wind power, the emissions of a wind turbine during its whole lifetime should be included. Among the various approaches, a prominent method is a lifecycle assessment (LCA) which considers the emitted GHG during the whole lifecycle of wind power systems. Such lifecycle assessments "include impacts from extraction, processing and transportation of fuels, building of power plants and generation of electricity" (Gagnon et al., 2002).

LCAs for wind power have been applied by e.g. Crawford (2009), Tremeac and Meunier (2009), or Turconi et al. (2013). In evaluations of GHG emissions, some authors refer to $\mathrm{CO}_{2}$ only, whereas other authors include other $\mathrm{GHG}$ like for example $\mathrm{CH}_{4}$ or $\mathrm{N}_{2} \mathrm{O}$ as well, transforming them into $\mathrm{CO}_{2}$-equivalents (eq) (Wagner et al., 2007). In terms of comparability and transparency, it is opted for the latter assessment to consider other GHGs as well. According to the available literature reviews (Turconi et al., 2013; Weisser, 2007; Radaal et al. (2011), GHG emission values range from 3-55.4 gCO -eq/ $\mathrm{kWh}$. These values should be compared with the emitted GHG emissions of substituted energy technologies, in order to evaluate the avoided emissions due to wind power developments.

As the use of renewable energies is supposed to reduce air pollution significantly in comparison to conventional energy generation technologies such as coal (Jacobson, 2009), renewable energy developments have also a positive effect on human health. According to WHO (2014), approximately $13 \%$ of deaths worldwide were caused by

66 Economic effects are not illustrated in value added, but in employee earnings only. In the operation stage, land owner benefits are also taken into account (an exception is Slattery et al., 2011). 
air pollution in 2012, making it "the world's largest single environmental health risk" (WHO, 2014). For ambient air pollution, the number of deaths in 2016 is estimated in 4.2 million (WHO, 2018). According to Eurostat (2016), 13\% of the most important acidifying gases and $8 \%$ of ozone precursors were emitted by electricity, gas, steam, and air conditioning supply in the EU-28 in 2014.

To enable methodological consistency, emission data which is used for GHG emissions is used for air pollution as well (Memmler et al., 2017). Specifically for air pollution, emission data of 2016 is used and an equal distribution of effects in the wind turbine lifetime is assumed to enable a calculation of net avoidance effects. In this regard, it is important to note that data should ideally be country specific and up-to date, taking into account the specific technology as well as the country specific energy system and substitution potentials.

\subsubsection{Avoided GHG emissions}

For the Aachen region it is referred to a study of the German Environment Agency (UBA) that evaluated the incurred and avoided emissions by generating electricity via renewable energy sources, on the basis of the principles of an LCA (Memmler et al., 2017). By wind power, electricity generated by black coal (61\%) and gas power plants (39\%) are substituted (Klobasa and Sensfuß, 2016 in Memmler et al., 2017). Differently, electricity generation by lignite that is exploited in the region does not play role, due to the merit order of electricity generation technologies (Memmler et al., 2017). Since values for 2017 were not available, data for 2016 were used, under the assumption that all wind turbines were installed before the beginning of 2017 (Equation 4.4).

\section{$N\left(g \mathrm{CO}_{2}-\mathrm{eq} / \mathbf{k W h}\right) \times \mathrm{M}_{\mathrm{el}}(\mathrm{kWh}) \times \mathrm{V}(€ / \mathrm{kWh})=\mathrm{B}(€)$}

$\begin{array}{ll}N & \text { net avoided emissions } \\ M_{\text {el }} & \text { generated electricity } \\ V & \text { monetised value of emissions } \\ \text { B } & \text { monetised benefits of avoided emissions }\end{array}$

Equation 4.4: Calculation of the monetised benefits of avoided emissions

The emitted greenhouse gases for onshore wind turbines are $11 \mathrm{gCO}_{2}$-eq/kWh in 2016 (Memmler et al., 2017), which lays in the range of the values, provided by the reviews of Turconi et al. (2013), Weisser (2007), and Radaal et al. (2011). When multiplied by the estimated electricity generated in 2017 (195,073,000 kWh; Section 4.3.3.3), they result 
in 2,086 $\mathrm{tCO}_{2}$-eq. The gross avoided emissions are $691 \mathrm{gCO}_{2}$-eq/kWh (Memmler et al., 2017) which corresponds to $134,856 \mathrm{tCO}_{2}$-eq. This leads to net avoided emissions of $132,770 \mathrm{tCO}_{2}$-eq $\left(681 \mathrm{gCO}_{2}\right.$-eq/kWh) for the Aachen region, which correspond to $0.29 \%$ of the avoided GHG emissions due to wind power in Germany in 2016 (Memmler et al., 2017).

Note that, in reality, that there is no equal distribution of effects over the wind turbine's lifetime since higher effects occur during manufacturing and construction (Weisser, 2007). However, in order to take into account all positive and negative effects, an equal distribution of effects over time was assumed.

As avoided emissions may be a quite abstract indicator for decision makers in the region, the economic benefits for avoided $\mathrm{CO}_{2}$-eq emissions are calculated, following Jenniches and Worrell (2019), by assessing the social cost of carbon (SCC), which may be defined as the net present value of damage costs of mitigating an additional unit of carbon in a specific point in time (Tol, 2015). These damage costs are the product of the positive and negative impacts of climate change effects such as sea level rise, energy, agriculture, water supply, and health, etc. (Watkiss et al., 2006).

SCC varies among model assumptions in different studies. As reported by lsacs et al. (2016), SCC ranges from $€ 6.3^{67}$ to $€ 734.4^{68}$ per ton $\mathrm{CO}_{2}$ in 2017.

In order not to underestimate climate change effects, a lower bound of $€ 98.8$ per ton $\mathrm{CO}_{2}$ in 2017, as proposed by van den Bergh and Botzen (2014) and representing a conservative estimate, is used as a SCC value. ${ }^{69}$ This leads to SCC of $€ 13,117,715$ (€0.07/ kWh electricity generated) in 2017 that can be interpreted as the economic benefits of $\mathrm{CO}_{2}$-eq mitigation due to wind power developments in 2017.

67 Isacs et al. (2016) illustrate a value of $€ 6.1$ per $\mathrm{tCO}_{2}$ in 2015 which is based on Tol (2013) and Bateman et al. (2014). The value has been converted into $2017 €$ by including a damage growth rate of $2.3 \%$ p.a. (Tol, 2013) and the inflation rate of Germany based on OECD (2018).

68 Isacs et al. (2016) present costs of $€ 724$ per $\mathrm{tCO}_{2}$ in 2015, based on Ackerman and Stanton (2012). The value has been converted into $2017 €$ by including a growth rate of damage costs per year (1.7\%) and the inflation rate for Germany based on OECD (2018).

69 The original value of $\$ 125$ per $\mathrm{tCO}_{2}$ of van den Bergh and Botzen (2014) has been converted into 2017 $€$ by using an average exchange rate (Deutsche Bundesbank, 2017). 


\subsubsection{Avoided air pollution and its economic impact}

Multiplying the electricity generated by each wind turbine in 2017 times the net emission reduction in tons per kWh of electricity generated by wind power in 2016 (Equation 4.4) yields a reduction of $89.73 \mathrm{t}$ of nitrogen oxides $\left(\mathrm{NO}_{\mathrm{x}}\right), 50.72 \mathrm{t}$ of sulphur dioxides $\left(\mathrm{SO}_{2}\right)$, 3.9t of non-methane volatile organic compounds (NMVOCs), 3.9t of dust, and (7.8t) of carbon monoxide (CO). Using the same source as for GHG emissions, it is possible to estimate that $0.29 \%$ of the national avoided air pollution related to wind power are due to wind power in the Aachen region (Memmler, 2017).

Due to geographic conditions such as population densities or the location of ecosystems as well as different atmospheric conditions that depend on the emitters' location (EEA, 2014), damage costs vary spatially. Data of EEA (2014) is used, evaluating the damage costs due to air pollution by European industrial facilities from 2008-2012 on a country level.

The damage costs of air pollution on human health is measured by a value of a life year (VOLY) and a value of statistical life (VSL).

The VOLY illustrates life expectancy decreases by considering the age of casualties whereas younger casualties are weighted higher than elder ones (EEA, 2014) and the VSL represents "individuals' willingness to pay to secure a marginal reduction in the risk of premature death" (WHO, 2015:VIII). In the analysis, a VOLY of $€ 68,000$ and a VSL of $€ 2,593,000$ (both values in $2017 €^{70}$ ) are used, representing values for the European Union, based on evaluations of the NewExt research project (Hurley et al., 2005) and are values which are typically applied in projects on a European scale (Hein et al., 2016). In a comparison of values, Hein et al. (2016) find VOLY estimates ranging from $€ 6,200$ to $€ 150,000$ and VSL estimates ranging from $€ 0.5$ to more than $€ 6,000,000$. Both values used can therefore be interpreted as slightly below the average value of existing studies in the field. However, the estimations are subject to uncertainty which should be taken into account when interpreting the results. Based on specific exposures to emissions, EEA (2014) provides country specific data for emitted pollutants (Table 4.7) where average values for Germany have been used.

70 Original vales are $€ 57,000$ (VOLY) and $€ 2,200,000$ (VSL). These values have been converted to $2017 €$ values using an inflation rate for Germany based on OECD (2018). 
Table 4.7: Avoided air pollution and economic valuation of wind power developments in 2017

\begin{tabular}{llllll}
\hline Substance & $\begin{array}{l}\text { Net avoided } \\
\text { air pollution } \\
(\mathbf{t})\end{array}$ & $\begin{array}{l}\text { VOLY } \\
(\boldsymbol{\epsilon} / \mathbf{t})\end{array}$ & $\begin{array}{l}\text { VSL } \\
(\boldsymbol{\epsilon} / \mathbf{t})\end{array}$ & $\begin{array}{l}\text { Economic value } \\
\text { of avoided air } \\
\text { pollution }(\boldsymbol{\epsilon})\end{array}$ & $\begin{array}{l}\text { Economic value } \\
\text { of avoided air } \\
\text { pollution }(\boldsymbol{\epsilon})(\mathbf{V S L})\end{array}$ \\
\hline $\mathbf{S O}_{\mathbf{2}}$ & 50.72 & 22,357 & 67,846 & $1,133,937$ & $3,441,052$ \\
\hline $\mathbf{N O}_{\mathbf{x}}$ & 89.73 & 8,040 & 22,479 & 721,473 & $2,017,097$ \\
\hline NMVOCs $^{71}$ & 3.90 & 2,230 & 5,628 & 8,701 & 21,958 \\
\hline Total & & & & $\mathbf{1 , 8 6 4 , 1 1 1}$ & $\mathbf{5 , 4 8 0 , 1 0 8}$ \\
\hline
\end{tabular}

(Source: own calculations based on Memmler et al. (2017) (emissions) and EEA (2014) (economic assessment ${ }^{72}$ )

Since the power grid is integrated it is difficult to evaluate the spatial distribution of air pollution reductions. Therefore, emission reductions take place inside as well as outside the region. The total economic value of avoided air pollution in 2017 ranges from $€ 1,864,000$ ( $€ 0.01 / \mathrm{kWh}$ electricity generated) (VOLY) to $€ 5,480,000$ ( $€ 0.03 / \mathrm{kWh}$ electricity generated) (VSL) because of wind power developments in the Aachen region in 2017 (Table 4.7).

\subsubsection{Comparison of the results with existing studies}

Factors influencing the results of external costs of avoided emissions include different methods used, different emission amount values, and different external costs, which makes a comparison of results among studies quite challenging (Sundqvist, 2004; Novan, 2015). Krewitt (2002), therefore, states that a "validation of external cost estimates is not possible" (Krewitt, 2002:840) but sees merit in comparing the results as it illustrates differences in the assessments. While existing studies in the field are not specific to German regions, most authors compare electricity generation by wind to coal and gas, which are the same energy carriers substituted as in this paper.

In the studies where wind power replaces coal or gas (e.g. Munksgard and Larsen, 1998; Sundqvist, 2004), avoided costs for wind substituting coal range from 3.7 to $8.5 \mathrm{c} / \mathrm{kWh}$ and are mostly higher than the avoided external costs for the substitution of gas (1.3-

71 EEA (2014) include secondary organic aerosols (SOA) into NMVOCs as well, whereas it is not clear whether they are included in the calculations of Memmler et al. (2017).

72 The values of EEA (2014) were originally in $2005 €$, which have been converted using an inflation rate for Germany based on OECD (2018). 
$9.9 \mathrm{c} / \mathrm{kWh}$ ) in the respective studies (e.g. McCubbin and Sovacool, 2013; Munksgard and Larsen, 1998). This is due to a higher amount of emissions by electricity generation from coal than from gas (Table 4.8).

Table 4.8: Avoided external costs of wind power generation in different studies in $\mathrm{c} / \mathrm{kWh}^{73}$

\begin{tabular}{|c|c|c|c|c|}
\hline Authors & $\begin{array}{l}\text { Wind replacing } \\
\text { coal (c/kWh) }\end{array}$ & $\begin{array}{l}\text { Wind replacing } \\
\text { gas (c/kWh) }\end{array}$ & $\begin{array}{l}\text { Wind } \\
\text { replacing } \\
\text { coal and } \\
\text { gas (c/kWh) }\end{array}$ & Region \\
\hline $\begin{array}{l}\text { Munksgard and } \\
\text { Larsen (1998) }\end{array}$ & $3.7-5.1$ & $1.8-2.7$ & - & Denmark \\
\hline $\begin{array}{l}\text { Roth and Ambs } \\
\text { (2004) }\end{array}$ & 7.9 & 5.5 & - & US \\
\hline Sundqvist (2004) & 8.5 & 3.7 & - & Global Sample \\
\hline \multirow{2}{*}{$\begin{array}{l}\text { McCubbin and } \\
\text { Sovacool (2013) }\end{array}$} & \multirow{2}{*}{-} & $1.5-9.9$ & - & $\begin{array}{l}\text { Altamont (CA)/ } \\
\text { US }\end{array}$ \\
\hline & & $1.3-6.9$ & - & $\begin{array}{l}\text { Sawtooth (ID)/ } \\
\text { (US) }\end{array}$ \\
\hline Cullen (2013) & - & - & 0.8 & Texas \\
\hline Novan (2015) & - & - & 2.2 & Texas \\
\hline This Paper & - & - & $7.7-9.5$ & $\begin{array}{l}\text { District of } \\
\text { Aachen }\end{array}$ \\
\hline
\end{tabular}

The most important cost parameter in most studies, disaggregating GHG and other emissions, are $\mathrm{CO}_{2}$ emissions, which corresponds to the findings of our study.

The range of avoided costs (1.3-9.9 c/kWh) in McCubbin and Sovacool (2013) derives from the estimation of a low and a high impact scenario with different amounts of emissions. In their study, the site specifity of assessments becomes apparent as there are different amount of emissions due to the efficiency of substituted power plants in the region, where the specific wind turbines are installed.

73 Values have been converted into $2017 €$ based on Deutsche Bundesbank (2017) and using an inflation rate for Germany based on OECD (2018). Net benefits have been calculated, following Timilsina et al. (2013). If several values were presented, a medium scenario has been chosen. In the evaluation of Novan (2015), nuclear energy and other not specified energy carriers are also taken into account. However, their impact has been considered negligible. 
Only a few studies take into account the actual energy mix substituted by wind power as stated by Novan (2015), who identified Cullen (2013) as the first paper studying "econometric estimates of the actual substitution pattern between wind generation and conventional generators" (Novan 2015:296).

The outcome of our study for wind power substituting coal and gas ranges between 7.7 and $9.5 \mathrm{c} / \mathrm{kWh}$. This result is a bit lower than in McCubbin and Sovacool (2013), mainly due to a lower $\mathrm{CO}_{2}$ price (8 times lower than in our study in Cullen, 2013; 4 times lower than in this paper in Novan, 2015). To conclude, there is a high level of uncertainty and variety regarding emissions and estimated external costs, which should be made transparent and regarded in the interpretation of the results.

\subsection{Conclusion and Policy Implications}

The total regional value added effects of 63.1 MW wind power developments in 2017 in the district of Aachen are $€ 50.8$ million ( $€ 805 / \mathrm{kW}$ ) consisting of profits of $€ 32.9$ million, net incomes of $€ 10.4$ million, taxes of $€ 7.6$ million, and employment effects of 309 person years (4.9 jobs per MW installed) (Table 4.5). Assuming a lower share of regional enterprises would lead to a value added of $€ 33$ million $(€ 523 / \mathrm{kW})$ and employment effects of 185 person years ( 2.9 jobs per MW installed), whereas the total regional value added highly depends on the electricity generation activity and implicitly on operators situated in the region. In fact, assuming only half of the operators being situated in the region would lead to a loss of total value added of $32 \%$. Consequently, regions should actively promote electricity generation by regional operators.

In 2017 alone, value added is $€ 5.9$ million ( $€ 95 / \mathrm{kW}$; $€ 31 / \mathrm{MWh}$ electricity generated). Employment effects are 101 person years. In the scenario with a lower share of regional enterprises, the value added is $€ 4.1$ million ( $€ 65 / \mathrm{kW}$; $€ 21 / \mathrm{MWh}$ generated) and the employment effects are 75 person years (Table 4.9). 
Chapter 4

Table 4.9: Economic effects of wind turbines installed in 2017 in the Aachen region in $€$ and in $€ / \mathrm{kW}$ in 2017, including a lower share of regional enterprises scenario (in brackets)

\begin{tabular}{|c|c|c|c|c|}
\hline Indicator & Category & Total (in $€$ ) & $€ / \mathbf{k W}$ & $€ / M W h$ \\
\hline \multirow{3}{*}{ Value added } & Profits & $(1,619,892) 2,340,549$ & (26) 37 & (8) 12 \\
\hline & Income & $(2,091,398) 2,978,473$ & (33) 47 & (11) 15 \\
\hline & Taxes & $(402,223) 644,606$ & (6) 10 & (2) 3 \\
\hline \multicolumn{2}{|c|}{ Total value added } & $5,963,629$ & 95 & 31 \\
\hline Avoided GHG & $\mathrm{CO}_{2}$-eq & $13,117,715$ & 208 & 67 \\
\hline \multirow{3}{*}{$\begin{array}{l}\text { Avoided Air } \\
\text { pollution }\end{array}$} & $\mathrm{SO}_{2}$ & $1,133,937-3,441,052$ & $18-55$ & $6-18$ \\
\hline & $\mathrm{NO}_{\mathrm{x}}$ & $721,473-2,017,097$ & $11-32$ & $4-10$ \\
\hline & NMVOCs & $8,701-21,958$ & $0.1-0.4$ & $0.04-0.11$ \\
\hline \multicolumn{2}{|c|}{ Total avoided air pollution } & $1,864,111-5,480,108$ & $30-87$ & $10-28$ \\
\hline \multicolumn{2}{|c|}{ Total (lower scenario) } & $19,095,339-22,711,336$ & $303-360$ & $98-116$ \\
\hline \multicolumn{2}{|l|}{ Total } & $20,945,455-24,561,451$ & $332-389$ & $107-126$ \\
\hline
\end{tabular}

Further benefits of $€ 13.1$ million arise by $132,770 t$ of avoided $\mathrm{CO}_{2}$-eq emissions. The positive impacts of non-emitted air pollutants on human health range from $€ 1.9$ million to $€ 5.5$ million. Total benefits in 2017 range from $€ 20.9$ to $€ 24.6$ million ( $€ 332-$ $389 / \mathrm{kW}$ or $€ 107-126 / \mathrm{MWh}$ electricity generated) in the baseline scenario and from $€ 19.1$ to $€ 22.7$ million in the lower scenario. Further benefits would occur if the amount of $\mathrm{PM}_{2.5}$ and $\mathrm{PM}_{10}$ emitted would be integrated in the analysis, which has not been done by Memmler et al. (2017) and there is further research needed.

The supply chain approach is a valuable instrument for analysing economic impacts of RES, especially on a small regional scale, since there is no need for an economic model that is often not available on a local or small regional level. Moreover, the analysis is very illustrative and it allows assessing the parameters determining the impacts very precisely, which is a benefit for stakeholders in the wind power market.

An important question for stakeholders in the region are the benefits of wind power, compared to the second most important renewable energy generation technology PV (render, 2016) and the conventional energy generation technology lignite which are all generated in the region. By comparing the levelized cost of electricity (LCOE) which takes into account all costs for electricity generation of a technology, one sees that it would most economical to generate electricity by lignite (Table 4.10). 
Table 4.10: Costs and employment effects of electricity generation of wind power, PV, and lignite in the Aachen region

\begin{tabular}{|c|c|c|c|c|}
\hline Technology & & Wind & $\begin{array}{l}\text { PV (large } \\
\text { rooftop) }\end{array}$ & Lignite \\
\hline LCOE (c/kWh) & & \multirow{2}{*}{6.36} & \multirow{2}{*}{6.71} & 4.59 \\
\hline LCOE excl. EU ETS carbon price (c/kWh) & & & & 4.36 \\
\hline GHG emissions ( $g / k W h)$ & $\mathrm{CO}_{2}-e \mathrm{q}$ & 10.69 & 67.81 & 413.15 \\
\hline Cost of emitted GHG (c/kWh) & $\mathrm{CO}_{2}$-eq & 0.11 & 0.67 & 4.08 \\
\hline \multirow{2}{*}{ Air pollution (g/kWh) } & $\mathrm{SO}_{2}$ & 0.01 & 0.07 & 0.23 \\
\hline & $N O_{x}$ & 0.02 & 0.09 & 0.26 \\
\hline \multirow{2}{*}{$\begin{array}{l}\text { Cost of emitted air pollution (VOLY) (c/ } \\
\mathrm{kWh})^{74}\end{array}$} & $\mathrm{SO}_{2}$ & 0.03 & 0.15 & 0.51 \\
\hline & $\mathrm{NO}_{x}$ & 0.02 & 0.07 & 0.42 \\
\hline $\begin{array}{l}\text { Costs of electricity generation (c/ } \\
\text { kWh) }\end{array}$ & & 6.51 & 7.59 & 9.37 \\
\hline $\begin{array}{l}\text { Regional employment (person years/ } \\
\text { GWh) }\end{array}$ & & 0.08 & 0.63 & $\mathbf{0 . 1 7 ^ { 7 5 }}$ \\
\hline
\end{tabular}

(Sources: LOCE of wind: own calculation (Section 4.3.4); LCOE lignite and PV (average value for Germany for large rooftop plants): Kost et al., 2018, modified); GHG emissions and air pollution: Memmler et al., 2017, GHG prices: van den Bergh and Botzen, 2014, modified) (see Section 4.4.1); cost of air pollution: EEA (2014, modified) (see Section 4.4.2); regional employment: wind power: own calculation (Section 4.3.4), lignite: own calculation based on employment and electricity generation of lignite (Section 4.4.2), PV: Jenniches and Worrell, 2019)

However, by integrating the external costs of GHG emissions and air pollution, wind power is the most economical electricity generation source, followed by PV, whereas the external costs of lignite make it the least economical option. The presented example is based on conservative assumptions as the lowest LCOE for lignite, which may - with an upper value of $7.98 \mathrm{c} / \mathrm{kWh}$ (Kost et al., 2018)- be well above the LCOE of wind power and PV, is chosen. Furthermore, the emissions of lignite electricity

74 We have chosen the VOLY here to provide a single value, following Hein et al. (2016) who consider -among others - the VOLY as a superior indicator for measuring air quality as VSL.

75 The calculation of the employment effects of lignite is based on another methodology as for wind power and PV, which makes a comparison difficult. 
generation are assumed to be quite low ${ }^{76}$, which illustrates the superiority of renewable energy sources compared to lignite. Differently from other studies (e.g. Sims et al., 2003; Munksgard and Larsen, 1998), the external costs of wind power generation are not considered zero, as emissions over the whole technology lifecycle (including plant manufacturing) are taken into account and not only energy generation, which makes the comparison more comprehensive.

Comparing the employment effects, the effects of wind power enable approximately half of the effects of lignite. However, due to methodological specifics, the estimation of the regional employment effects of lignite is quite high and regions nearby are also considered, though the lignite mine (Section 4.2) is only partly situated in the Aachen district.

Most of the employment effects (nearly 4 times more than lignite) account for PV which is due to more regional PV enterprises in the region, whereas specialised enterprises for wind power are located in other regions.

Investing $€ 1$ million in wind, PV, or lignite allows a generation of $15.7 \mathrm{GWh}$ of wind power, 14.9 GWh of PV and 21.8 GWh of wind power. However by taking into account the external costs, the same investment would lead to $15.4 \mathrm{GWh}$ of wind power, 13.2 GWh of electricity by PV, and $10.7 \mathrm{GWh}$ of lignite. The regional employment effects of the investment are 1 person year for wind, 9 for PV, and 4 person years for lignite.

In summary, from an environmental and economic perspective, the development of PV and wind power is preferable than investing in lignite electricity generation, where the generation costs of wind power are the lowest. From a socioeconomic perspective, PV is the preferable electricity generation technology. Regional decision makers should therefore always opt for developing PV over lignite. The decision between developing wind or lignite is based on a trade-off between environmental economic and socioeconomic concerns, whereas, from a global view, the long term negative effects of climate change may be more important than individual regional employment. Differently, a balanced deployment of PV and wind should consider

76 The costs of lignite range between 4.49-7.98 c/kWh depending on the full load hours and the carbon prices of the EU Emissions Trading System of lignite. To avoid double counting, the carbon costs are have been excluded by using an average carbon price value for 2017 ( $€ 5.58 / \mathrm{tCO}_{2}$; European Energy Exchange AG, 2017). The GHG emissions of lignite, used by Memmler et al. (2017) are relatively low in comparison to other sources. Using the average value of the literature analysis by Wagner et al. (2007) would lead to emissions of $1,083 \mathrm{~g} / \mathrm{kWh}$ electricity generated, which would lead to GHG emission costs of $11 \mathrm{c} / \mathrm{kWh}$. 
technical issues, in addition to environmental and (socio)economic aspects. From a regional employment perspective, the deployment of $\mathrm{PV}$ is more beneficial than wind power, although energy generation costs are slightly higher. In any case, to achieve a total electricity supply by renewable energies, wind power remains necessary: even by exploiting the whole PV potential in the region, the regional electricity demand could not be satisfied by PV alone (render, 2018).

In this regard, incentives are needed to foster the transformation to a low carbon energy system in fossil fuel regions and to steer regions towards a low carbon energy policy, as local governments might prefer to support local jobs rather than reducing emissions, which is a classic "tragedy of the commons" (Hardin, 1968:1245) challenge. This can be solved by fully taking into account the negative impacts of fossil energy generation. Internalising the external damage costs could be done by making emitters accountable or by rewarding operators or regions for their efforts to avoid GHG and air pollution.

However, regions relying on fossil fuels have to compensate structural employment market changes by providing alternative opportunities for employees in the fossil fuel industries. In this case, job training is necessary. Ultimately, the number of jobs depends on the ability of regions to attract RES industries as well as on the renewable energy generation potentials, which both support a sustainable economy in the long term.

\section{Acknowledgements}

The outcomes presented in this paper have been assessed in the render (Regional Dialogue Energy Transition) project that is part of the FONA (Research for Sustainable Development) programme funded by the German Federal Ministry of Education and Research (BMBF) (FKZ 033L116G). The authors gratefully acknowledge funding from the FONA programme of the BMBF. 



\section{Energy Transitions at the Subnational Scale: How to Get the Former German Frontrunner Region Aachen Back on Track}

This chapter is based on the submitted paper: Jenniches S, Truffer B, Fumagalli $E$, Worrell E. Energy transitions at the subnational scale: How to get the former German frontrunner region Aachen back on track (submitted). 


\section{Abstract}

This paper calls for a regional approach to energy transitions leveraging regional specifics instead of national averages. Taking local variation into account allows for a more efficient analysis of specific transition challenges instead of evaluations on the national scale that are mostly found in the literature. We build on the multilevel perspective in order to analyse the energy transition in the German region of Aachen, an early mover in renewable energy development which also relies strongly on coal production. Regional interaction patterns between the established regime and the niche are analysed. We find that especially informal institutions drove the implementation and promotion of renewable energies. Building on these informal institutions, the paper provides policy advice to successfully manage the regional energy transition in the future. The approach may be transferable to other regions as well. 


\subsection{Introduction}

There is broad academic consent that the emission of greenhouse gases (GHG) is leading to global warming and climate change causing severe impacts on ecosystems (Umweltbundesamt, 2019c). A large number of international and national GHG mitigation strategies has been formulated. Looking specifically at Germany, a commitment was made to reduce them by 2020 to about $40 \%$ compared to the 1990 level (BMU, 2017a). In this regard, several supportive factors have emerged: studies have shown that such a goal is technically feasible (Kopiske and Gerhard, 2018) and economically viable as electricity generation by solar photovoltaic (PV) and onshorewind is meanwhile cost competitive with electricity generated by fossil fuel plants (Kost et al., 2018). Furthermore, there is a broad societal support of the energy transition (Agentur für Erneuerbare Energien, 2017). Nevertheless, the $40 \%$ target will presumably not be achieved (Kopiske and Gerhard, 2018). This raises the question: what kind of barriers still hinder the energy transition despite major drivers pointing in the right direction?

The present paper maintains that in order to identify hindering or promoting factors of the implementation of the energy transition in a country, the analysis should focus on regional or local processes. Every region possesses a specific development potential, which depends on geographical factors (e.g. wind potential, solar irradiation, agriculture and land use etc.). Other locally varying factors are the extent and capacity of the energy infrastructure, capabilities in the regional economy, as well as cultural characteristics of the sub-national territories (Keppler, 2007; Bonnemaison et al., 2005). Moreover, the adoption of renewable energies (RE) is rather a local or regional, than a national responsibility in many countries. This is because municipalities or regions may have the power to hinder or promote the implementation of new technologies. For example, necessary building permissions for wind power developments often fall under local responsibility (Jacobsson and Bergek, 2004; Jenniches et al., 2019). Despite these conditions, regional characteristics (e.g. dependence on fossil fuel exploitation) are often overlooked in national appraisals of energy transition potentials. In other words, there is a missing link between national targets, on the one hand, and conditions for regional implementation, on the other. In a similar way, a policy aiming at a national energy transition has to take regional contexts into account.

This paper addresses this gap by looking at hindering and enabling factors of the energy transition at the regional level. Our analytical framework is composed of two elements. First, to analyse the energy transition at the regional level, we adopt a sociotechnical system perspective (Verbong and Geels, 2007; Walker and Cass, 2007). This allows for a comprehensive view, as it introduces a social perspective into an analysis 
that is often dominated by techno-economic arguments (Bolton and Foxon, 2015). By implementing a multi-level perspective (MLP) (Section 5.2) we describe how, also at a regional level, $\mathrm{RE}$ evolve in niches, facing opposition by the existing sociotechnical regime by following the conceptualisation of Smith et al. (2010) and Verbong and Geels (2007). Both innovative technologies and sociotechnical regimes are influenced by broader developments such as societal trends - the sociotechnical landscape. The fundamental restructuring of a sector results from dynamics operating simultaneously at these three levels (Geels, 2002; Geels, 2005; Geels and Schot, 2007; Voß et al., 2009; Geels, 2012).

In a further step, we want to elaborate how a multi-scalar understanding of sustainability transitions can come to bear. Transition approaches have been criticised for their insufficient consideration of the spatial dimension (Hansen and Coenen, 2015; Bridge et al., 2013; Truffer et al., 2015) as, for example, the spatial reach of institutions is inadequately addressed (Coenen et al., 2012). In fact, most studies analyse processes at the national level (Markard et al., 2012) - examples are Geels (2005), Kern (2012), or Belz (2004). However, they miss factors which operate at the regional level interacting with spatial "variations and reproduction[s] of regime structure[s]" (Truffer and Coenen, 2012:10). In other words, by focusing on the national level only, studies do not explain why, for example, the initial market formation of clean technologies occurs in specific regions and not in others or why some regions perform better in the energy transition, even though techno-economic conditions may be largely similar (Dewald and Truffer, 2012).

For this reason, the second key component of our analysis is the concept of sociospatial embeddedness, which is like multi-scalarity also derived from the Geography of Sustainability Transitions (GOST) literature (Truffer et al. 2015; Hansen and Coenen; 2015). Socio-spatial embeddedness encompasses the characteristics of places in terms of available capital, infrastructure, physical geographical potential, the political system, informal (such as individual cultures) and formal institutions (Amin, 1999). ${ }^{77}$ These factors may either support or hinder the implementation of a more sustainable energy transition (Truffer et al., 2015; Bridge et al. 2013; Wirth et al. 2013). Accordingly, socio-spatial embeddedness enables a better understanding of conditions for energy transitions and support the formulation of adequate regional policies.

77 Formal institutions may be defined as rules, laws, standards and regulations, whereas informal institutions may be referred to as culture, habits, "customs, traditions, and codes of conduct" (North, 1991:97). 
In the paper we apply the proposed framework to a region and describe the energy transition process regarding the interplay between the existing regime and the innovative niche by referring to actors, formal institutions, and technologies (as in Geels et al., 2016). Furthermore, we enrich the analysis by looking at informal institutions, as well as at technical, economic, environmental, and social-acceptance issues. In this regard, a distinction between RE technologies is essential, as every technology has particular techno-economic characteristics, environmental impacts, and social acceptances. Therefore, the analysis illustrates the energy transition not only in its regional, but also in its technological variations and options which has, to such an extent, not been done in other MLP studies so far.

Specifically, the focus will be on the historical mining region of Aachen, located in the West of the federal State North Rhine-Westphalia in Germany (Figure 5.1). Using qualitative and quantitative data, as well as narrative analysis, we find a powerful regime based on fossil energy generation, resulting in a hostile environment for alternative technologies. Nevertheless, the Aachen region has also been the forerunner in terms of RE promotion: the highly effective national feed-in tariff as part of the national renewable energy act (EEG) was first developed here (Jenniches and Worrell, 2019).

However, renewable energy implementation has recently fallen behind expectations, although, economic benefits, technical potentials, and social acceptance can be considered high. These features make the region quite an interesting case to study, but also an extreme example of the interplay of relatively strong national and regional conditions, regarding to niche and regime characteristics. This allows for transferring the results into other regional contexts where conditions may be more moderate. Nevertheless, this analysis provides the basis to formulate suitable policy measures, thus making use of the full potential of the MLP (Kern, 2012).

In this regard, the proposed analytical framework generates generalisable lessons which can be used in performing integrated analysis of technical, economic, and social acceptance of the energy transition in other regions as well. Based on that, several research questions are formulated: how do niche innovations interact with potentially hostile regional socio-technical regimes (e.g. regimes depending on the fossil energy industry, such as in mining regions)? What (spatially-embedded) factors may support the emergence of novel (clean-)technologies in a region? (see Section 5.4.3) What are barriers that slow down the transition? What are drivers of regional transitions which one may build upon to support further developments of renewable energies? (see Section 5.5). 
Finally, we need to clarify the concept of a region. The administrative region of the district of Aachen (German: Städteregion Aachen) is the relevant spatial unit for an analysis of regional characteristics such as economic data, population surveys, or energy system analyses. The evaluation of the wider structural region is relevant because mining and energy generation are historically quite significant in the Aachen district as well as in the adjacent district of Düren. Both are part of the Rhenish lignite mining area (Rheinisches Braunkohlerevier). We therefore use the term Aachen district, representing the administrative district of Aachen and the Aachen region for the district of Aachen and Düren, when we refer to the parts of the region, where mining and energy generation from lignite takes place and where we find a regional specialisation on research and development. ${ }^{78}$

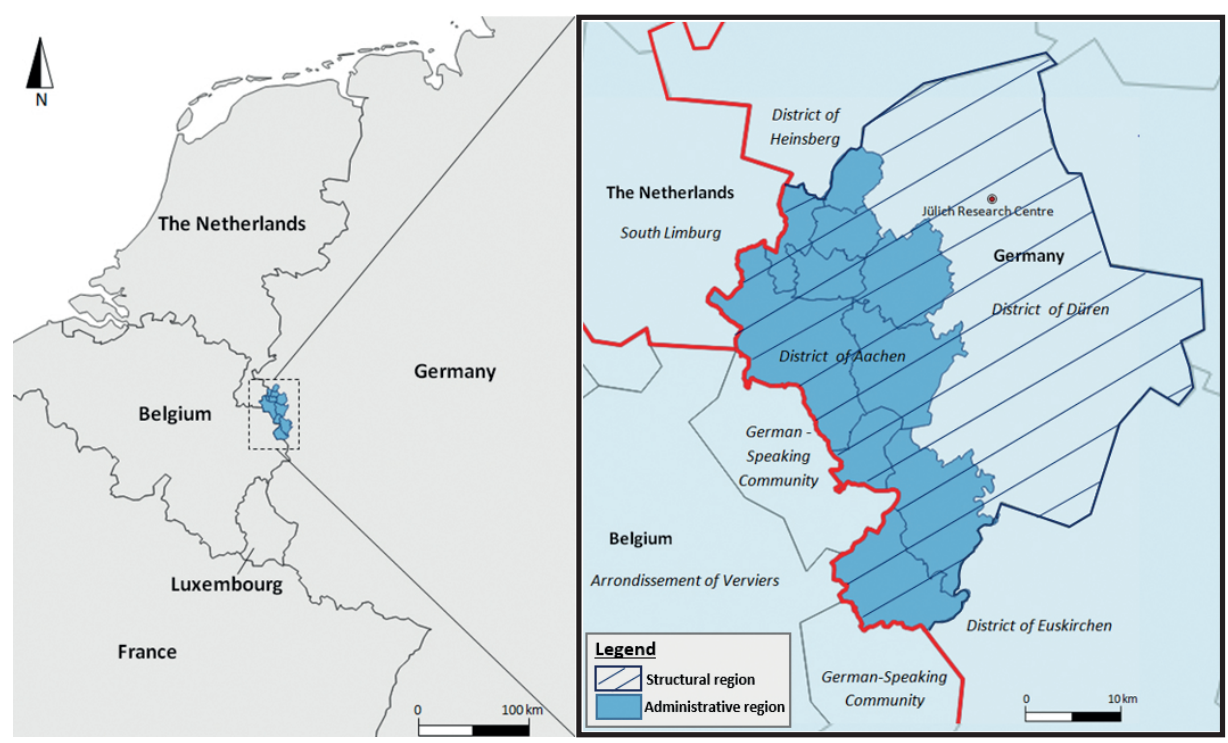

Figure 5.1: Situation of the district of Aachen (German: Städteregion Aachen) in Europe (left) and neighbouring territorial units (right) on NUTS 3 level (Source: Jenniches and Worrell, 2019, modified; map data sources: Eurostat, s.a.a)

The paper is structured as follows: after introducing the MLP (Section 5.2), the data gathering process is briefly presented (Section 5.3). The regional characteristics enabling niche formation, the incumbent regime and their interaction are elaborated, by taking the relative importance of regional actors, institutions, and technologies into

78 The area of the district of Düren, as well as the district of Heinsberg, and Euskirchen, together with the district of Aachen and the city of Aachen also form part of the historical governmental district of Aachen and are referred to as the Aachen region (Region Aachen Zweckverband, s.a.). This is a rationale for labelling the district of Aachen and Düren as the 'Aachen region'. 
account (Section 5.4). This analysis provides the basis for proposing policy measures to steer the regional energy transition in the future (Section 5.5).

\subsection{The multi-level perspective}

The multi-level perspective (MLP) allows for the analysis of transitions by referring to a systemic view composed of three different structural levels, namely niches, regimes, and landscapes, interacting with each other (Geels, 2005). A common assumption that is often found in the original literature is that socio-technical regimes are mostly located at the national level, whereas niches operate at more local scales and landscape forces represent globally operating context conditions (Truffer and Coenen, 2012). Only later, geographers have introduced a multi-scalar perspective by revealing that all three socio-technical configurations operate at global, national, and local scalar levels simultaneously (Coenen et al., 2012; Murphy, 2015; Coenen and Truffer, 2012; Binz and Truffer, 2017). As a result, although widely applied and recognised by sustainable transition scholars, MLP analyses often take the dimensions of space and scale into account insufficiently.

A particularly critical point is that most MLP based papers implicitly adopt a national view on socio-technical regimes (Smith et al., 2010). This creates a risk for the analysis to overlook variations within countries that might potentially impact the success and shape of a transition (Raven et al., 2012). For instance, informal institutions may exhibit a high degree of sub-national variation, e.g. regarding an identification with mining rooted in a regional culture, but there also may be a regional concentration of actors of the incumbent regime such as the mining and fossil fuel industry. In the following, we discuss why niche and regime need to be studied at the regional level, i.e. why their spatial embeddedness is relevant.

\subsubsection{The regional variation of niches}

Niches may be defined as shielded experimental spaces for radical innovations where they can evolve and are protected against established processes and influential incumbent actors (Schot et al., 1994).

Protecting measures to support these innovations are necessary as they are still expensive, cumbersome, and suffer from technological teething problems (Geels, 2002). These measures are, however, instruments for "governing transitions into socially desirable directions" (Raven et al., 2010:59). What is socially desirable may be different on a spatial scale. For instance, while climate change mitigation is desperately 
needed, RE developments may not be a socially desired strategy in every region (Graf, 2018). Hence, we argue that social support of alternative energy generation options needs to be assessed at the regional level.

Moreover, niches are not as highly institutionalised as established regimes because formal institutions such as laws or standards and informal institutions such as codes of conduct, customs, and habits (North, 1991) still have to be developed. Also, the adoption of a technology by users and the integration into "practices, organisations and routines" (Geels, 2004:902) is still in an early stage. Again, informal institutions supporting niche formation such as customs, practices and habits, vary across regions and should be analysed consistently (Keating, 2001; Keating et al., 2003; Bonnemaison et al., 2005).

In sum, we argue that the relative regional capability to absorb innovative technologies into the local context might explain why the adoption of innovations and therefore the transition to RE occurs earlier in some regions than in others. Differently, in most analyses, the impact of socio-spatial embedding, i.e. how the spatial situation such as infrastructure, or the availability of natural resources and the local and regional institutional setting influence the formation and maturing of niches, has been missing (Coenen and Truffer, 2012).

\subsubsection{A multi-scalar view on socio-technical regimes}

Innovations evolving in niches are confronted with existing regimes, i.e. the setting of mature technological and institutional arrangements as well as incumbent firms (Audretsch, 1997). A technological regime, originally introduced by Nelson and Winter (1982) may be defined as:

"the rule-set or grammar embedded in a complex of engineering practices, production process technologies, product characteristics, skills and procedures, ways of handling relevant artefacts and persons, ways of defining problems-all of them embedded in institutions and infrastructures. Regimes are intermediaries between specific innovations as these are conceived, developed, and introduced, and overall sociotechnical landscapes" (Rip and Kemp, 1998:338).

Whereas some traits of the regime may be defined at a national level, such as national laws and standards, others have a specific regional character. For instance, as lignite mining and energy generation mostly take place in close proximity, we find a concentration of several industries dependent on fossil fuels at a sub-national 
scale. As already argued, also informal institutions, social norms and behaviour may vary regionally. One example for this may be lignite mining regions, where RE are considered a threat to conventional energy generation and therefore might negatively impact incumbent job profiles. Therefore, this paper distinguishes the national dimensions of a regime from the local and regional ones.

\subsubsection{Socio-technical landscape level}

The sociotechnical landscape is described by overarching factors impacting both niches and regimes and has an influence on the overall transition dynamics (Geels, 2002). As a general characteristic, landscapes are beyond the direct influence of actors located at the level of specific regimes or niches (Geels, 2005). Developments on the landscape level encompass global trends such as climate change or resource availability. These developments may contest an existing regime (climate change and fossil fuel availability question the existing regime of carbon intensive electricity generation) and therefore, create windows of opportunity for niches to develop.

\subsection{Data collection}

The objective of this study is to assess regional patterns of niche formation and regime interdependencies in the context of RE development for the Aachen region.

The analysis of the regional transition path is conducted using an MLP, enriched by spatial embeddedness and multi-scalarity. By describing the past (mainly since the 1990s) and current regional situation and factor endowment, lessons can be drawn to further support the adoption of RE in the region.

We use quantitative data from e.g. economic analyses (integrating the geographical situation such as solar or wind potential and the environmental benefits of RE), regional energy assessment studies, and a population survey (in 2017) about the energy transition in the region. ${ }^{79}$ As for the relevance of informal institutions, we use qualitative narrative research in order to reconstruct the regional pattern that explains the diffusion of RE (Lieblich et al., 1998; Andrews et al., 2013). Data sources are project workshops and conferences about future energy scenarios for the region, interviews with stakeholders regarding the regional energy transition, and newspaper articles.

79 In the following results of the population survey in 2017 , only answering interviewees are taken into account. 
Data have mostly been gathered in the regional dialogue, energy transition render, that started in $2015 .^{80}$ The project incorporated a multidisciplinary approach, as especially in complex challenges affecting multiple dimensions, such as energy transition, an integrated analysis is needed. To transfer the knowledge gained into practical implementation, the project used a transdisciplinary approach, as well. The render project core group was formed by actors from science and consultancies, as well as practitioners from the administration and the energy sector (i.e. utility companies). An extended public expert group was formed by further participants and actively promoted (render, 2018). The group participated in various workshops, acting as a forum and contributing to activate other relevant regional stakeholders. These other stakeholders were a heterogeneous group of actors such as politicians, energy companies, civil society (also RE opponent groups), administrative groups, chambers of commerce, associations, scientists, etc.

\subsection{Managing the energy transition in the Aachen region}

This section follows Geels at al. (2016) and structures the description of the energy transition in the region by looking at actors and institutions first and technologies second. The same structure applies to the description of regime (Section 5.4.1) and niche (Section 5.4.2). A summary of findings is also provided (Section 5.4.3).

\subsubsection{Regime dynamics}

The Aachen region is one of the oldest European mining regions where black coal was mined until 1997 (Bergbaumuseum Grube Anna, s.a.). Lignite is still exploited in the lignite mine Inden and used for energy generation in the power plant Weisweiler, operated by RWE Power AG. A Location Quotient (LQ) of 2.5 indicates the specialisation of the Aachen district in coal mining in comparison to the federal state North RhineWestphalia and illustrates significance of the lignite industry in the region..$^{81}$ Indeed,

80 The project was part of the Research for Sustainable Development (FONA) programme of the German Federal Ministry of Education and Research targeting sustainable development challenges. The first author was part of the project team. The view of the authors does not automatically correspond to the view of the project render.

81 The location quotient (LQ) illustrates the specialisation of the region by comparing employment of a spatial unit (e.g. municipality, district) with a superordinated spatial unit (e.g. federal state or country). A location quotient less than one illustrates a lower significance of a sector in a region, and a quotient larger than one a higher significance than in the superordinated spatial unit. The data source for the calculation of the location coefficient is Bundesagentur für Arbeit (2017). 
one of the main challenges for the Aachen region is the phase-out of the Inden mine and of the power plant Weisweiler, both planned for 2030.

\subsubsection{Actors and institutions}

Relevant regional actors include the association Zukunftsagentur Rheinisches Revier which was founded to manage the regional structural change, to overcome the related challenges, and to promote new economic development. The district of Aachen, the Aachen Chamber of Commerce, the Chamber of Crafts, and the region of Aachen are all associates of the organisation (IRR, 2019). Furthermore, mining and energy generation form part of the cultural identity in the region and people are proud of their heritage. In particular, mining associations aim at preserving the mining traditions (Landesverband der Berg-und Knappenvereine NRW, 2019). Finally, the organisation Energy Hills e.V., headquartered in the Aachen district, is the largest, energy-related network of universities, research institutes, and companies at the European level. Its members from outside the district of Aachen, are mostly located in the Rhineland and in the Netherlands (Energy Hills e.V., 2017).

As for formal institutions, we note that the Chamber of Commerce (IHK Aachen), whose objective is to support the regional economy, lists standards such as energy security, lignite, and inexpensive energy among the defining factors of a future energy regime in the region. The Chamber has to balance the interests of its member enterprises, which are actively involved in the renewable, but also in the fossil-based energy sector (IHK Aachen, 2014).

\subsubsection{Technology and institutions}

Lignite

The lignite phase-out after 2030 will be a challenge for the energy industry in the region. The lignite plant Weisweiler generates a gross amount of 15.3 TWh of electricity per year as well as heat, since a combined heat and power system is integrated in the plant (RWE Power AG, s.a.). The debate so far can be described with reference to the public opinion, on the one hand, and the alternative technological opportunities, on the other.

At the Hambach lignite mine in the district of Düren, there is a strong protest coalition against the use of lignite for energy generation and the destruction of the Hambach forest. The conflicts between protesters and the law enforcement forces have initiated 
a nationwide debate about the exploitation of lignite. The media even compared the 2011 Fukushima disaster, a significant event that nurtured the German nuclear phase-out, to the lignite protest that may eventually support a rapid lignite phaseout (Flauger, 2018; Gries, 2018). The German commission of coal, which envisaged to end the exploitation of coal by 2038, advised not to further promote the use of the Hambach forest (ARD, 2019). Under pressure from politics and the media, RWE agreed not to clear the forest until autumn 2020 (Aachener Zeitung, 2019a).

However, there are also supporters of the lignite industry. An analysis conducted of newspaper articles and comments of the readership reveals a conflict between supporters of lignite and opponents, representing the struggle between the current energy regime and the evolving niche in the region (Aachener Zeitung, 2019b; Aachener Nachrichten, 2018). Interestingly, the Chamber of Commerce, which has openly promoted the lignite industry in the past (to ensure supply security against the intermittent energy generation from wind power and PV, and as a pillar of the local economy) (IHK Aachen, 2014) has recently changed its position. The Chamber of Commerce now calls for an energy transition, albeit by underlining stable and secure energy supply and affordable energy costs (IHK Aachen, s.a.b). In this regard, it is important to observe that there are economic challenges linked to the phase-out: in 2009, approximately 2,672 employees worked in the lignite industry (the mine Inden and the power plant), which is therefore accountable for 0.2 jobs per GWh electricity generated (Jenniches et al., 2019). Fearing unemployment, miners demonstrated against the lignite phase-out in 2018, even as they admitted that the energy transition may be necessary (Aachener Nachrichten, 2017).

The possibilities of substituting lignite by wind and PV was evaluated by Memmler et al. (2014). They state that electricity generated by wind and PV substitute lignite only by a small proportion in Germany. However, if storage capacities for RE existed, full substitution may be possible. Notably, according to a population survey, only $8 \%$ of the interviewees opt for a very significant or significant role of lignite development in the district of Aachen whereas $79 \%$ did not see it as important. Interestingly, in the parts of the region where the lignite mine is situated (Eschweiler/Stolberg), this number is only a bit lower (69\%) (RISP, 2017).

\section{Nuclear Power}

The German nuclear phase-out by 2022 was determined by the German government in 2011 (Presse- und Informationsamt der Bundesregierung, 2018). Nuclear energy is not generated in the region and research activities at the Jülich Research Centre 
currently focus on nuclear safety, decommissioning, and waste management of nuclear energy plants. Nuclear safety is a big concern, because of several incidents at the Tihange 2 nuclear plant (near Liège, Belgium) located approximately $60 \mathrm{~km}$ from Aachen (Städteregion Aachen, s.a.a). Landscape developments such as the Fukushima nuclear disaster in 2011 led to a growing public concern about nuclear safety that strengthened the pressure on the regime. For instance, the district of Aachen requested a safety report which revealed the risk of contamination in case of nuclear fallout caused by a nuclear accident (Arnold et al., s.a.). Moreover, in 2016 the district of Aachen in cooperation with the municipality of Maastricht (The Netherlands) and the city of Wiltz (Luxembourg) filed a law suit against the State of Belgium, the Belgian Nuclear Safety Agency (FANK), and the operating company Electrabel S.A. to achieve the shut-down of the Tihange nuclear plant (Städteregion Aachen, s.a.a). Around the same time, Belgian, Dutch, and German Civil movements supported the shut-down of Tihange and Doel (near Antwerp, Belgium) with a massive movement and protested with a human chain (Norddeutscher Rundfunk, 2017). Against the background of the safety concerns in the Belgian nuclear plants, the interviewees of the population survey in 2017 widely (85\%) disagree with the statement that relying on nuclear energy would be inevitable in the future (RISP, 2017).

\subsubsection{Renewable niche innovations}

The render project estimated that in the district of Aachen only $16 \%$ of the electricity consumed in 2017 was generated from RE (render, 2018). This is less than half of the German average of $36 \%$ and clearly shows the urgent need for a lignite phase-out and a RE transition. Interestingly, regional actors (such as politicians or civil society organisations) involved in the render project were quite disappointed as they learned about the comparatively low performance of the region: in their heuristic view, the region performed rather well from an environmental perspective (indeed, the assessment also indicated that the regional climate change mitigation targets would not be met by the current development dynamics). The view of these actors is partly explained by the region's role as an early mover in institution building for RE and by the region's role in research and development in the energy sector, leading to the perception that the regional engagement in RE developments may be significant (IHK Aachen, 2014).

This section describes in more detail the regional, innovation niche pertaining to RE technologies. The struggle between the regime and the niche is analysed by looking at the interplay of actors, institutions, and RE technologies, where we focus on wind and rooftop PV as the most important technologies. 


\subsubsection{Actors and institutions}

One of the characteristics of the German energy transition is that energy market incumbents play only a minor role in the promotion and operation of RE plants. In 2013 nearly half of the plants were operated by citizens (i.e. private persons and cooperatives), whereas only $12 \%$ were owned by utility companies in Germany (Agentur für Erneuerbare Energien, 2014b). In the Aachen district citizens operate the majority of renewable power plants as well (render, 2016). This is different to other countries where the energy transition is significantly steered by incumbents (e.g. the UK). Instead, new local actors (private persons or energy cooperatives) enter the market and challenge existing professional business models (Geels et al., 2016). Faced with decreasing stock values (finanzen.net $\mathrm{GmbH}, 2019$ ), energy incumbents recently founded RE branches such as Innogy (formerly RWE) or, in the case of E.ON, outsourced their fossil energy generation branches into new companies (i.e. Uniper SE). Another important stakeholder in the region is the PV initiative Solarenergieförderverein (SFV), which played a key role in the niche formation process. Finally, a wide network of environmental protection groups is active in the region (Liesenfeld et al., 2015).

From a political perspective, the relatively high importance of environmental topics is evidenced by the $14 \%$ share of the green party in the parliament of the district of Aachen (Städteregion Aachen s.a.b), which is more than double compared to the state North-Rhine Westphalia (Der Präsident des Landtags NRW, s.a.). As for the local (i.e. municipal) administration, the district of Aachen is in a relatively strong position to take over a coordinative role for the whole district (Stachowiak, 2016).

Concerning R\&D and qualification, the region is known as an important (energy-) technology hub. The strong focus on engineering and research is demonstrated by the presence of several universities (the university RWTH Aachen, the University of Aachen research campus, and the Aachen University of Applied Sciences), three Fraunhofer Institutes, and the Jülich Research Centre (JRC), as well as several technology and engineering institutes (Lühr et al., 2017). A location quotient of 5.3 for research and development in the Aachen district and of 13.7 in the district of Düren underlines the regional specialisation. ${ }^{82} \mathrm{In}$ fact, the region is referred to as the Technologieregion Aachen (technology region Aachen). This term is used, for example, by the economic development agency AGIT and other officials (AGIT, s.a.; MWIDE NRW, s.a.). The focus on research and engineering, a high interest in technological developments, and the

82 As the main part of the employees in R\&D in the district of Düren work at the Jülich Research Centre, $R \& D$ activities are organisationally more concentrated than in the district of Aachen, which has, however, an organisationally more diversified R\&D community. 
identification and self-perception as an (energy-)technology region are all part of the daily culture and may be regarded as a regional narrative that influenced the niche formation and continues to drive the regional energy transition.

For the future energy system, a population survey reveals high support $(95 \%$ of answering interviewees) for the development of RE. In addition, 93\% of the interviewees support the implementation of policy recommendations that have been evaluated by research projects like render. This shows how informal institutions strongly support and create legitimacy for such a transition (RISP, 2017).

Among the formal institutions which are relevant for the niche dynamics, environmental targets play, a relevant role. A number of international climate mitigation targets have recently been transferred to a national and even regional scale. These targets can be regarded as a formal institution. The Aachen district, decided to envisage a reduction of $\mathrm{CO}_{2}$ emissions to $40 \%$ in 2020 and $80 \%$ in 2050 in comparison to 1990 (Städteregion Aachen, 2011). Furthermore, the district set a target share of $75 \%$ of RE to be achieved in final energy consumption by 2030 (Städteregion Aachen, 2015). To evaluate the achievability of this target, the future electricity consumption in 2030 was estimated within the render project..$^{83}$

Electricity consumption is projected to decrease only slightly from 2,968 GWh in 2013 to $2,763 \mathrm{GWh}$ in 2030 . To achieve a $75 \%$ share of renewable electricity, approximately $2,050 \mathrm{GWh}$ of electricity should be generated by renewable sources. In turn, meeting the $75 \%$ goal exceeds the $80 \% \mathrm{CO}_{2}$ emission reduction target in the electricity sector and fulfils, therefore, both regional targets (Donner, 2016).

Conclusively, the analysis shows strong actor coalitions as well as institutions in favour of RE. Potential barriers hampering RE developments currently and eventually in the future will be illustrated by the technology specific evaluation conducted in the next subsection.

\subsubsection{Technology and institutions}

Before evaluating potential RE developments, it is important to analyse whether the $75 \%$ target is achievable in the district of Aachen. This illustrates an aspect of the socio-

83 The render project focused on electricity generation. However, noted that an overcompensation in the electricity sector is needed to fulfill the target for the sectors heat and transport as well. 
spatial embeddedness of RE developments as they depend on the geographic factor endowment (e.g. irradiation, wind potential, and available spaces).

The theoretical potential of all technologies is $5,900 \mathrm{GWh}^{84}$ which is 2.2 times the electricity consumption in 2030 (Figure 5.2). This potential excludes locations where the development of plants affects environmental concerns such as nature conservation areas.

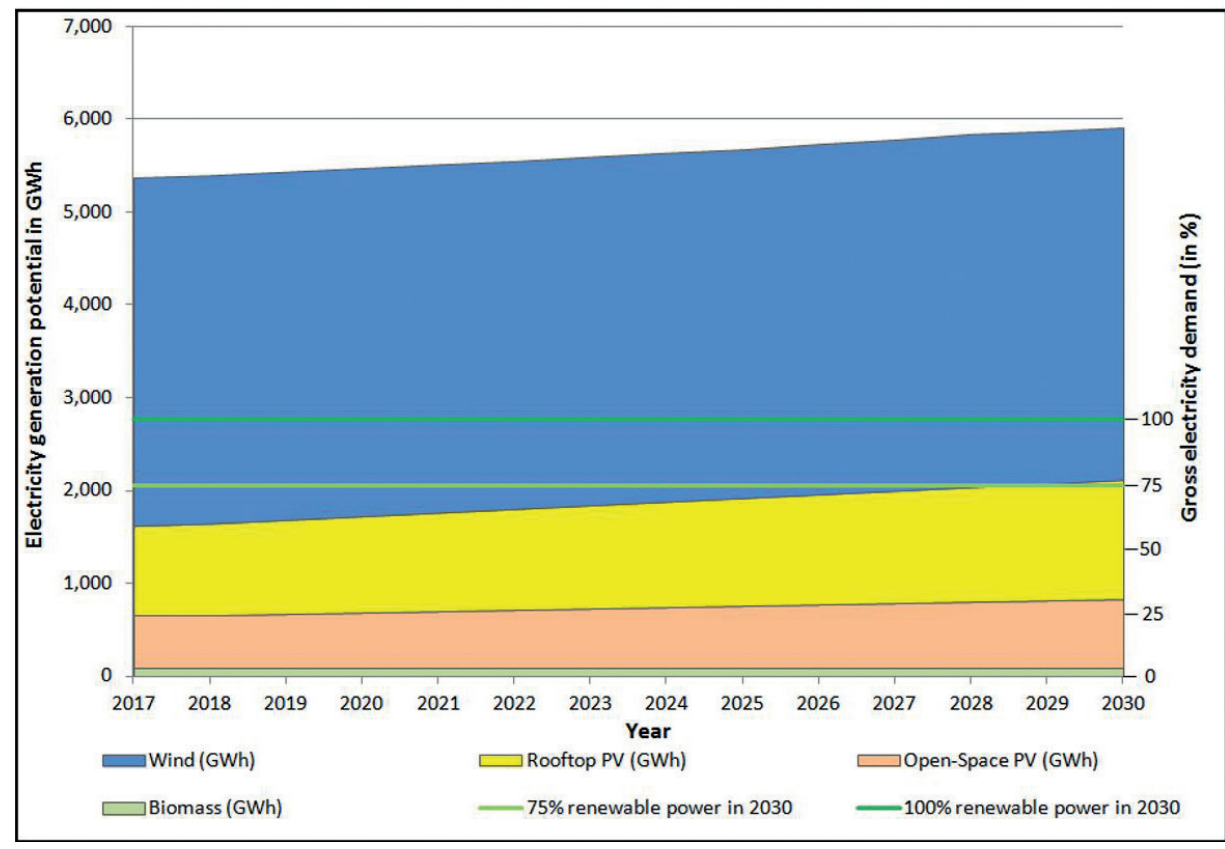

Figure 5.2: Electricity generation potentials from renewable sources in the district of Aachen per technology (Source: own calculation based on LANUV (2013) and an analysis using a geographical information system (GIS) tool developed in render)

The achievability of the $75 \%$ target for electricity generation was communicated in the region by the render project (render, 2018) in order to encourage regional stakeholders to proceed in the regional energy transition and to weaken arguments of RE opponents who consider the target as unrealistic. However, the mere geographical potential is a necessary precondition, but not a sufficient one, as economic (e.g. profitability of

84 The analysis of the regional energy generation potentials was carried out, based on a geographic information system (GIS) tool which was developed in the render project, taking plant lifetimes, future space requirements, and efficiency gains based on Fraunhofer ISE (2015) (for PV) into account. 
plants) issues and the institutional setting (such as laws for planning regulations and zoning), and social (e.g. acceptance issues), have to be considered as well.

The introduction of a cost covering compensation for the operation of plants, as the predecessor of the feed-in tariff is the success of an initiative in the region. It was driven by the technology PV and highly depended on the activist Wolf von Fabeck and the local solar energy support association Solarenergieförderverein (SFV) which may be considered as change agents (Pastakia, 1998; Cerf, 2011), catalysing formal institution building for cleantech. From an environmentalist perception, von Fabeck realised the urgent change that was needed to avoid air pollution that was caused by fossil energy generation (Rubner, 2005). As he studied mechanical engineering, he had a technical understanding that enabled him considering technical solutions, where he discovered PV as an alternative to conventional energy generation technologies (Rubner, 2005). von Fabeck and other activists demonstrated the feasibility of PV on public squares in the Aachen region by showing that with solar panels, electric devices could be operated, which attracted the interest of citizens. This interest in engineering and enthusiasm for innovative technologies (Rubner, 2005), as described in the regional narrative, led to the conviction that the technology worked and had to be promoted. That was the birth of an initiative for the full cost compensation for RE, the so called Aachener Modell, which later was adopted by the German feed-in tariff (Morris and Jungjohann, 2016; von Fabeck, 2014). These events induced a conflict between employees of RWE and supporters of RE in the region (von Fabeck, 2014), hindering the implementation of the full cost compensation. As a result, the full cost compensation was introduced in other cities first, before Aachen, although the idea originated from there (Morris and Jungjohann, 2016).

\section{Rooftop PV}

Rooftop PV developments generated 73.2 GWh of electricity in the year 2017 in the district of Aachen. The potential for rooftop installations will dramatically increase due to efficiency gains (Fraunhofer ISE, 2015), which will save on space consumption for installed capacities. When current plants are deinstalled, they will provide space for more efficient plants. The potential is 957 GWh annually by the end of 2017 and without further developments - 1,276 GWh annually by 2030 (46\% of the electricity consumption in 2030). In relation to other regions in North Rhine-Westphalia, the Aachen region has excellent conditions for PV development (Jenniches and Worrell, 2019). 
In 2018, the electricity generation costs - Levelized Cost of Electricity (LCOE) - of PV in the district of Aachen are estimated at $€ 0.09 / \mathrm{kWh}$ for small rooftop plants which are typically installed on single family homes and $€ 0.07 / \mathrm{kWh}$ for larger rooftop plants which are installed on commercial and public buildings. ${ }^{85}$ The technology provides for economic benefits as plants installed in 2014 generate a value added of $€ 196 /$ $\mathrm{kW}^{86}$, employment of 0.63 person years ${ }^{87}$ per GWh in 2014. Positive environmental effects exist with avoided net greenhouse gas (GHG) emissions of $0.7 \mathrm{kgCO}_{2}$-eq/ $\mathrm{kWh}$ generated and avoided air pollution of $0.6 \mathrm{gSO}_{2}$-eq $/ \mathrm{kWh}$ in $2014 .{ }^{88}$ These effects have been monetised summing up to $€ 55 / \mathrm{kW}$ of avoided $\mathrm{CO}_{2}$ (Social Costs of Carbon; SCC) and $€ 9.26 / \mathrm{kW}$ of avoided air pollution. Thus, the positive economic and environmental effects are $€ 260-277$ per kW installed in 2014 (Jenniches and Worrell, 2019). Future PV markets will mostly rely on self-consumption of electricity, which is since 2012 more profitable than demanding a feed-in tariff especially in buildings with a constant electricity demand (e.g. supermarkets, farms, or industrial estates). Lower system costs, which are expected to decline by $62 \%$ in 2030 compared to 2010 according to Schröder et al. (2013) and prospected rising electricity prices (Schlesinger et al., 2014) make PV even more profitable. Storage of electricity, which is currently still too expensive for some projects will become profitable on a larger scale due to lower system costs (Hubik, 2015). Furthermore, people have an enhanced connection to energy if they produce, consume (prosumer; Reinsberger and Posch, 2016) and share it in their community, instead of being just a consumer. That is supposed to foster energy efficiency. ${ }^{89}$

The population survey reveals great support for PV with $79 \%$ of the interviewees rating future PV developments in the district of Aachen as very important (55\%) or important (24\%) which makes it the most important energy generation technology (RISP, 2017). ${ }^{90}$ Therefore, from a sustainability perspective, rooftop PV meets economic, environmental, and social objectives.

85 Average value for Germany, based on Kost et al. (2018), as the LCOEs may be project specific.

86 The regional economic value added is a measure for the economic benefits in a region and consists of profits (after taxes) of regional enterprises, net income of employees of regional enterprises, and regional taxes (Jenniches and Worrell, 2019).

87 This figure includes employment of large rooftop plants only.

88 The net avoided emission takes into account the emissions of the technology as well. For a detailed analysis see Jenniches and Worrell (2019).

89 In that case, there is a discussion about the rebound effect of more consumption because of allegedly cheaper energy from renewable energy generation. Oberst et al. (2016) evaluate the rebound effects of prosumers. However, the question could not be properly answered and more research is needed. Other technologies were lignite, biomass, CHP, open-space PV, and wind power 


\section{Storage}

One flagship storage project in the region is the $5 \mathrm{MW}$ storage system M5BAT, which is integrated into the local grid, where researchers from various institutes and private companies test the applicability of such storage systems in the field (E.ON SE, 2017). Another project is the planned low emission area Richtericher Dell mainly for employees of RWTH Aachen Campus, where generation, consumption, storage, and distribution solutions for RE are planned to be implemented. This has been evaluated in a scenario process by the render project with multiple stakeholders (Stawag, 2017). A big chance for RE and especially PV is the increasing development of e-mobility, providing storage opportunities that may make the investment in PV more profitable. Aachen takes a special position as a testing region for e-mobility. Moreover, two important local manufacturers (e.go and StreetScooter) whose models have been developed in cooperation with RWTH Aachen University are located in the region.

\section{Wind Power}

Wind energy generation in the district of Aachen amounted to $371 \mathrm{GWh}$ in the year 2017 which is 5 times higher than rooftop PV and makes it the most important renewable electricity source in the district of Aachen. The generation potential in 2017 is 3,748 GWh ${ }^{91}$ and will increase to 3,793 by 2030 due to the decommissioning of plants as well as increased efficiency. If the potential can be fully exploited, it will exceed electricity demand by 1.4 times (Figure 5.2), which makes wind power the most important and most promising RE technology.

Economic effects of plants installed in 2017 are a value added of $€ 95$ per kW in 2017 and employment effects of 0.08 jobs per GWh electricity generated. Environmental benefits in 2017 are avoided GHG emissions of $0.7 \mathrm{kgCO}_{2}$-eq/ $\mathrm{kWh}$ generated and 0.6 $\mathrm{gSO}_{2}$-eq/kWh of air pollution (Memmler et al., 2017). Monetising the environmental effects leads to $€ 208 / \mathrm{kW}$ of avoided $\mathrm{CO}_{2}$ and $€ 30-87$ per $\mathrm{kW}$ of air pollutants. ${ }^{92}$ Total effects are therefore $€ 332-389 / \mathrm{kW}$ for plants installed in 2017 (Jenniches et al., 2019).

A very strong or strong approval of wind power developments near the place of residence is expressed by $60 \%$ of the interviewees, which is a higher approval than for biomass, but a lower approval than for open-space PV. However, with $58 \%$ of interviewees fearing very big or big conflicts with wind power developments, the

91 The potential has been calculated by taking wind concentration areas, wind potential areas, and other spaces into account. Furthermore, municipalities provided reasons, why they did not favour wind power developments on specific sites.

92 Not every particular air pollutant could be monetised. 
conflict potential is the highest. The most often named negative effects are noise, followed by wind power plants' visual impact on the landscape. Wind energy developments are rated as very important or important for the district of Aachen by 77\% of the interviewees in 2017 (RISP, 2017).

Although the support for wind energy is generally high among the population, project specific protests may successfully hinder wind power developments. An example are protests against wind power in the small village Schevenhütte, which stopped wind farm plans of a local energy company. The reason behind protests was that locals were annoyed by another large-scale project (a dam) which was built, although the population was against it. This supported the protests against the wind farm. However, they admitted that they would reconsider their position if they could participate financially (Interviewee A, 2019). Moreover, the wind farm was supposed to be built in a forest which evoked protests because of environmental concerns (Müller, 2016). Furthermore, the visual impact on the landscape was criticised. These points illustrate the importance of the informal institutional norms and values in the region, as environmental concerns, as well as fairness and social justice play a role in the development of wind power. This supports previous research on wind power acceptance (Gross, 2007; Wolsink 2007; Wüstenhagen et al., 2007). Although wind power developments are regulated by public participation in the building authorisation process, participation - even in the region - is quite low (RISP, 2017) and protests take place even if decisions have already been made. A negative example are the protests against the railway project Stuttgart 21 in Southern Germany (BMU, 2017b; Stüer and Buchsteiner, s.a.). This calls for integrating the public in an alternative way to enable more efficient planning and project development processes. That is supported by the citizens, where $80 \%$ of the interviewees state that they see additional and alternative modes of participation in planning processes as at least important and $81 \%$ say that they would eventually participate in such alternative participation processes. Moreover, $47 \%$ of the interviewees in the district of Aachen want the citizens to have direct decision possibilities instead of letting the regional parliaments and councils decide (RISP, 2017).

R\&D activities in the region are carried out, for example, at the Center for Wind Power Drives at RWTH Aachen University and at a small wind turbine manufacturer located in the region. For large wind power plant manufacturing, where German enterprises still hold a large market share, there are no Original Equipment Manufacturers (OEM) located in the region and it may be resource intensive to catch up in knowledge and manufacturing expertise and building a distribution network compared to other established actors in the market. 


\subsubsection{Summary of findings}

Current developments in the regime and the niche illustrates that the current electricity regime is challenged and under heavy pressure. As the German nuclear phase-out is set for 2022, and nuclear power is, moreover, not generated in the region, it does not play a significant role. However, there exists the fear of fallout caused by the nearby Tihange 2 nuclear plant. The population strongly supports the nuclear phase-out, and we cannot find strong and powerful actor coalitions in favour of nuclear energy (Städteregion Aachen, s.a.a; RISP, 2017). This is where RE may be presented to regional actors as an alternative to nuclear energy.

The vast majority of the population also sees no future for power generated by lignite. A symbol of resistance of the population against the destruction of nature and use of lignite, demonstrating environmentalist culture in the region, is the Hambach forest that led to a public debate, even on a national scale, questioning the further exploitation of lignite. As the phase-out in the region will be in 2030 (RWE Power AG, 2009), lignite will not play a significant role in the future energy generation system, making the region an example for an early transition, which is supposed to happen nationwide in 2038.

In the region, we still find a cultural identification with mining. A new paradigm is visible in the changed positions and actions of traditional regime incumbents such as the Jülich Research Centre, the IHK Aachen, and even RWE (Innogy), who now support the niches as well. The Aachen region is even presented as a successful economic transition region to other regions such as the Ruhr area, where hard coal mining ended in 2018 (ARD, 2018). To conclude, the highly challenged electricity regime in the region provides a window of opportunity for RE due to the phase-out of technologies and their decreasing acceptance.

The early emergence of cleantech in the region is explained by the spatially-embedded factors, environmental consciousness and a distinguished culture of technological interest. The fact that actors outside the region took on the idea of a full cost compensation accounts for the multi-scalarity of sustainability transitions. Moreover, it illustrates the struggle between the niche and the regime, which hampered the niche formation in the region, but regime inertia was finally overcome by public pressure. R\&D activities have shifted from a focus on PV towards other research areas to grid and storage, as in the overall trend in the German PV industry (Binz et al., 2017b; Quitzow, 2015; Dewald and Fromhold-Eisebith, 2015). 
The following integrated summarising evaluation of RE technologies (Table 5.1), allows the evaluation of their disadvantages and advantages, which one can build upon to stimulate the development of RE. Due to the different characteristics of RE technologies, technology specific regional strategies are needed. Wind power electricity generation is cheaper than PV and the environmental benefits are higher. Moreover, the region cannot fulfil its energy and emission mitigation targets without relying on wind power. PV has a slightly higher acceptance than wind power, but far more regional economic benefits in terms of value added and employment effects. Developing PV is, therefore, an important strategy to compensate the future regional economic losses in the lignite mining industry, which may be a barrier for phasing out lignite faster (Aachener Zeitung, 2019b), that is also indicated by several stakeholders, including the employees of the lignite industry.

Table 5.1: Comparison of sustainability indicators of PV and wind power in the district of Aachen

\begin{tabular}{|c|c|c|c|}
\hline \multirow{2}{*}{ Dimension } & \multirow{2}{*}{ Indicators } & \multicolumn{2}{|l|}{ Technology } \\
\hline & & Rooftop PV & Wind Power \\
\hline \multirow{3}{*}{ Economic } & LCOE & $\begin{array}{l}€ 0.07 / \mathrm{kWh} \text { (large)- } \\
€ 0.09 / \mathrm{kWh} \text { (small) }\end{array}$ & $€ 0.06 / \mathrm{kWh}$ \\
\hline & Regional Employment ${ }^{93}$ & $\begin{array}{l}0.63 \text { person years/ } \\
\text { GWh }\end{array}$ & $\begin{array}{l}0.08 \text { person years/ } \\
\text { GWh }\end{array}$ \\
\hline & Value Added & $€ 196 / \mathrm{kW}$ & $€ 95 / \mathrm{kW}$ \\
\hline \multirow[t]{2}{*}{ Environmental } & $\begin{array}{l}\text { Value of avoided } \mathrm{CO}_{2} \\
\text { Emissions }\end{array}$ & $€ 55 / \mathrm{kW}$ & $€ 208 / \mathrm{kW}$ \\
\hline & Value of avoided air pollution & $€ 9-26 / \mathrm{kW}$ & $€ 30-87 / \mathrm{kW}$ \\
\hline \multicolumn{2}{|c|}{ Economic and Environmental effects } & $€ 260-277 / \mathrm{kW}$ & $€ 332-389 / \mathrm{kW}$ \\
\hline Social & Support of developments ${ }^{94}$ & $79 \%$ & $77 \%$ \\
\hline
\end{tabular}

(Sources: LOCE of wind: Jenniches et al. (2019); LCOE PV (average value for Germany): Kost et al. (2018, modified); GHG emissions and air pollution: Memmler et al. (2014, 2017), GHG prices: van den Bergh and Botzen (2017, modified); cost of air pollution: EEA (2014, modified); regional employment: wind power: Jenniches et al. (2019), PV: Jenniches and Worrell (2019)

To conclude, from a sustainability perspective, the development of both PV and wind power is beneficial as there are no economic or environmental barriers, and are

93 Assessed in 2014 for PV and in 2017 for wind power

94 Measured by the share of respondents rating the further development of a technology as very important or important 
supported by the public (Table 5.1). Therefore, building on the institutional setting in the region may support further developments of RE in the region, which is illustrated in the following (Section 5.5).

\subsection{Conclusion, policy implications, and recom- mendations for future research}

Targeted policy implications are formulated based on the analysis of barriers and supporting factors of the energy transition. This acts like a blueprint for transition analyses, which is applicable to other regions as well.

The strong focus on research and development in energy as well as the region's role in the early periods of the German energy transition has led to the illusive self-perception of local actors that the region performed better in RE development than it was the case. In this regard, actors were not informed properly about the actual achievements of energy generation targets and were misled by the region's role in R\&D which made them think developed technologies were used in the region as well. This is where the regional perception culture triggered by the achievements in technology and engineering, led to misperceptions about the status quo in RES developments. This slowed the energy transition in terms of development achievements as they were not soundly assessed, nor critically questioned and, therefore, overestimated.

Consequently, transparent monitoring of the energy transition on a digital platform involving information on the location of plants, energy consumption and generation, status quo of development, and climate protection goals, should be implemented as a policy measure (render, 2018). This information platform provides a realistic assessment of the fulfilment of the transition objectives. Ideally, this platform is hosted by a trustworthy independent organisation, enabling objective monitoring.

Economic and environmental impacts of RE developments (Table 5.1) should be continuously investigated and presented to decision makers (i.e. public administration, citizens, politicians, regional enterprises) to illustrate the benefits of RE developments. Presenting these benefits relates to the local informal institutions, a culture of technical interest of the population and environmental consciousness. Such assessments which strengthen the legitimisation of the energy transition may also be implementable in other regions.

Environmental concerns and the visual impact on landscapes, which are rooted in the environmentalist culture in the region, are barriers to the implementation of wind 
power developments and have to be taken seriously by decision makers. Therefore, developments should be decided on a more participative basis to identify the least controversial sites. In this regard the trade-off between the environmental impact of wind power and climate change mitigation should be properly investigated. To design informal and formal planning processes more efficiently and inclusively, the public participation which is obligatory in planning processes in Germany should redesigned. Ideally, the advantages and disadvantages of individual projects should be analysed and presented by a neutral institution (e.g. by illustrating projects on the above-mentioned digital platform) (Engelbert et al., 2017). Another form are citizens' reports, where planning processes of projects are taken over by private persons. In this format, ordinary citizens give advice on projects with the support of professionals (e.g. spatial planners, biologists), to enhance participation and acceptance (Gesellschaft für Bürgergutachten, 2017). Fairness and social justice concerning a distribution of negative and positive impacts is essential in projects that affect citizens (Rupert-Winkel et al., 2013). Consequently, compensation measures, which include at least financial participation of residents in nearby wind farms should be implemented to foster the acceptance of the energy transition. A best practice example has been implemented in the federal state Mecklenburg-Vorpommern where the right to buy RE project shares for citizens or comparable compensation measures has been made compulsory by law (Gotchev, 2016). Regions facing similar challenges in participation processes may also make this solution. There is further research needed on how to overcome public resistance of the energy transition in a fair way.

Although the centre of PV R\&D has shifted to Asia, research institutes in the region do research on future challenges of the energy system such as infrastructure, grid, and storage. The fact that Aachen is a testing region for electricity storage as well as e-mobility, for example, demonstrates the regional capability to take part in experimentation and knowledge diffusion for cleantech industries. These activities in the region will further nurture the citizens' regional perception as a cleantech region and support informal institutions of embracing new technologies in the future. Using the socio-spatially embedded institution of a technology culture may, therefore, be used to support the energy transformation. A concrete measure based on this culture may be the promotion of further intermitted electricity generation and consumption on a local scale (prosumer). In this regard, providing room for experimentation with new technological applications is, therefore, seen as a big chance for the region.

To conclude: the socio-spatial embeddedness of energy generation and consumption, environmental consciousness, and a culture embracing technological progress led to the early mover position of the region in renewable energies. Building on that culture 
with tailored measures will support further niche developments in the region. This makes the region an example for other German regions in the energy transition, with a similar culture of embracing technological advancement (e.g. some regions in BadenWürttemberg). Further research should, therefore, take a more local and regional view and consider socio-spatially embedded institutions to further gain an understanding of individual barriers and drivers of the energy transition. This understanding is a prerequisite to identify adequate policy measures for the further development of renewable energies.

\section{Acknowledgements \& Disclaimer}

The outcomes presented in this paper have been assessed in the render (Regional Dialogue Energy Transition) project that is part of the FONA (Research for Sustainable Development) programme funded by the of the German Federal Ministry of Education and Research (BMBF) (FKZ 033L116G). The authors gratefully acknowledge funding from the FONA programme of the BMBF. The views and opinions expressed in this article are those of the authors and do not necessarily reflect the official position of WFG Wirtschaftsförderungsgesellschaft Krefeld mbH. 



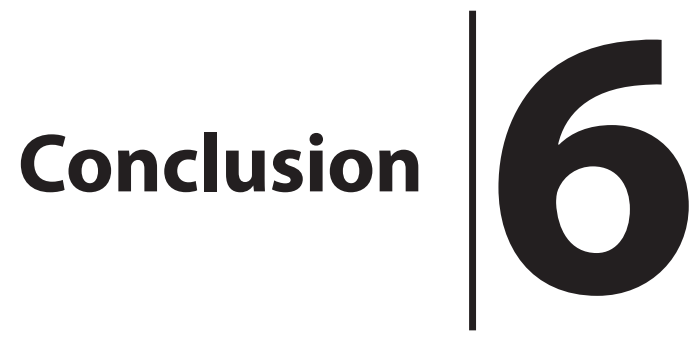




\subsection{Summary of the results}

An increasing deployment of renewable energies is an effective strategy for tackling one of the most important challenges of our common future: climate change mitigation. In most OECD countries, decisions regarding the implementation of renewable energies are taken on local or regional scales. This is due to the far-reaching local and regional autonomies in terms of planning for land use and the decisionmaking powers of regional stakeholders such as citizens, politicians and enterprises. As the economic and environmental benefits of renewable energies are supportive factors for further developments, decision-making instruments and investigations into impacts are necessary to provide sound investigations of the effects of renewable energies on local and regional scales. Most studies in the literature that assesses the economic impacts of renewable energies investigate employment effects or other economic effects such as regional taxes or salaries of employees.

The indicators to be evaluated depend on the research aim and the target group of the assessment. Politicians or the local media, for example, are mainly interested in the effects on employment, while economic development organisations may be more interested in the precise economic impacts in terms of the gross regional domestic product (GRDP) or the value added. In addition to these indicators, the size of the region or the time for the occurrence of effects (i.e. current or future) are decisive when it comes to selecting an adequate assessment method for measuring the regional economic effects of RES. Based on that information, a tailored assessment methodology may be chosen to conduct a comprehensive assessment of the regional economic impacts of renewable energies (RQ 1: What is the most suitable method for evaluating regional economic effects of renewable energies?). This thesis contributes to existing studies as there is no comprehensive overview on the advantages of individual methods to efficiently evaluate the regional economic impacts of renewable energies. The overview provided in the thesis may be used as a decision support instrument for practitioners in the field when choosing a suitable assessment method. Moreover, if the presented overall impact assessment guideline is considered, the validity of assessments is enhanced which may lead to a higher appreciation of the chances of deploying renewable energies in a region by decision makers.

The most efficient method for evaluating the regional economic effects of renewable energies depends on the aims, conditions and indicators being assessed, where one can distinguish between economic indicators (i.e. employment or other economic effects) and the size of the region to be analysed, such as small ( $<=$ NUTS 3 for regions in the EU) and large (> NUTS 3 for regions in the EU), as well as the times of the impacts (i.e. current or future impacts). 
The thesis finds that RIOTs are the most efficient instrument for assessing current economic or employment effects in large regions (e.g. NUTS 1 in the EU or states in the US). A CGE model is the most suitable instrument for evaluating future employment or economic effects in these regions. Employment ratios are suitable for assessing current employment effects on small regional scales. The current and future economic effects of renewable energies in these small regions can be assessed most efficiently through a supply chain analysis. To sum up, in large regions with extensive statistical databases, economic models such as RIOTs or CGEs that rely on regional statistical data may be the most suitable, whereas in smaller regions analytical models like employment ratios or supply chain analyses lead to more precise results. A limitation of the research carried out in the thesis lies in the fact that the methods of analysis concern only instruments that evaluate the quantitative economic effects of renewable energy developments. An analysis and a comparison of methods for assessing other qualitative economic effects such as the regional innovation capability in the cleantech sector, which lead to further economic chances in terms of employment and export potentials, are not considered.

In addition to the economic impacts, environmental effects, such as avoided GHG emissions leading to reduced damages on ecosystems or a reduction in air pollution that has positive effects on public health, are additional macroeconomic benefits of investing in renewable energies. By monetising these benefits, the thesis presents an illustrative and comprehensive assessment of the positive economic and environmental benefits for the technologies with the largest renewable power generation potential in Germany (PV and wind power) (RQ 2: What regional economic and environmental effects are generated because of the development of solar PV and wind power?). In doing so, the view of decision makers on the full impacts of renewable energies is broadened. Moreover, in the comparison of various studies, the evolvement of the wind and PV market are highlighted which enables a better understanding of the impacts of PV and wind power over time and the dynamics in the markets.

The regional economic and environmental effects of PV and wind power may be assessed for each region individually because of specific geographical conditions (e.g. solar irradiation, wind power potential, or the availability of local cleantech enterprises) that affect the results. Based on the outcomes of Chapter 2, the comparison of the assessment tools for economic impacts reveals that a supply chain analysis is the most suitable method for analysing the current economic impacts of renewable energy developments in a small region such as the district of Aachen in Germany. 
In the case of rooftop PV, the results of studies in the field vary because of individual calculation methodologies, a decreasing value added in time because of lower system investment costs resulting from learning effects and declining feed-in tariffs. Because feed-in tariffs are usually lower than the electricity prices, we find that, mainly since 2012 in Germany there has been a market shift from business models based on fixed feed-in tariffs for generated electricity to self-consumption. In the district of Aachen, where the regional economic and environmental effects of PV are assessed by a supply chain analysis, the deployment of 280 PV plants with a total capacity of 3.7 $\mathrm{MW}$, generating $3.4 \mathrm{GWh}$ of electricity per year leads to a total regional value added of $€ 3.8$ million ( $€ 1,019$ per kW installed; $€ 57$ per MWh of electricity generated) and employment effects of 42 full-time person years (11 person years per MW installed) from 2014 to 2034.

The avoided GHG emissions resulting from PV deployments in 2014 in the region account for 2,365 tons $\mathrm{CO}_{2}$-equivalents per year ( $0.7 \mathrm{kgCO}_{2}$-eq per $\mathrm{kWh}$ ) generated). Furthermore, air pollution of $0.97 \mathrm{tSO}_{2}$ per year, $1.48 \mathrm{tNO}_{x}$ per year and $0.07 \mathrm{t}$ NMVOCs per year is avoided. Monetising the environmental effects illustrates a benefit of $€ 3-55$ per kW (€4-62 per MWh) for reduced GHG emissions and €9-26 per kW (€929 per MWh) for avoided air pollution. The positive environmental effects of avoided emissions of $€ 13-91$ per MWh are in line with other studies, where Owen (2006) finds a median lower bound of $€ 36$ per MWh for avoided emissions of PV substituting coal and lignite across countries in the EU. In total, the economic and environmental economic effects of PV plants installed in 2014 in the district of Aachen lead to $€ 208-277$ per kW (€231-307 per MWh electricity generated) per year.

For the case involving wind power, the regional economic impacts of wind power developments in studies vary because of decreases in feed-in tariffs and differences in the methodologies used. Further significant factors are the physical (i.e. wind power potential) and the economic (i.e. availability of local enterprises in the wind power sector) geographic features of regions. With regard to the case study for the district of Aachen, 63.1 MW of wind power operating from 2017 to 2037 and generating 195.1 GWh per year generate a value added of $€ 50.8$ million ( $€ 805$ per kW or $€ 13$ per MWh electricity generated) over 20 years of operation. Employment effects are 309 person years from 2017 to 2037 (5 person years per MW installed). In 2017 alone, these effects (101 person years) account for $0.05 \%$ of total employment in the district.

In 2017, the avoided emissions are $132,770 \mathrm{tCO}_{2}$-equivalents, $89.73 \mathrm{tNO}_{x^{\prime}} 50.72 \mathrm{tSO}_{2^{\prime}}$ $3.9 \mathrm{t}$ of NMVOCs, and $7.8 \mathrm{tCO}$ per year. This leads to positive macroeconomic effects of $€ 13.1$ million for avoided GHGs and €1.9-5.5 million for avoided air pollution. The total 
effects of avoided emissions are $€ 77-95$ per MWh, which is in the high range of values (€8-99 per MWh) found by other studies. In summary, the total economic impacts of value added, avoided GHGs, and air pollution in 2017 range from $€ 20.9-€ 24.6$ million (€332-389 per kW or €107-126 per MWh electricity generated).

A comparison between rooftop PV and wind power reveals differences concerning their respective impacts on land use, with wind power being more space intensive and differences with respect to ownership, since wind power plants are not as frequently owned by private persons as PV. In addition, the distribution of monetary effects varies. Fewer parties benefit from wind power than from PV where, especially for small-scale $\mathrm{PV}$, a broader range of regional actors and industries is positively affected.

A limitation of the research carried out in this thesis lies in the fact that accounting for avoided regional damages because of regionally reduced GHGs and air pollution is not possible because of the dispersion of gases and pollutants into the air, making geographical allocations difficult. Therefore, positive environmental impacts that affect only a specific region cannot be illustrated explicitly. In the case of PV, a prognosis is used to estimate future electricity prices but the impact of uncertain future electricity prices on the results has not specifically been explored. Moreover, storage solutions leading to a higher self-consumption of generated electricity by PV are not considered.

Particularly for regions that rely on fossil fuels, it is important to compare the effects of investing in renewable energies to the impacts of fossil fuels to prepare the ground for a reasonable and responsible energy policy. This type of comparison is also needed to reveal the future economic opportunities in a decarbonised society and to elaborate on how investing in renewable energy sources may compensate for the negative effects of a potential economic downturn resulting from a fossil fuel phase-out (RQ 3: What are the regional economic and environmental benefits of renewable energies in relation to conventional energy carriers?). The comprehensive assessment of the impacts of investments in renewable energies and fossil fuels from an economic and environmental perspective on a regional level closes a gap that is not considered in the literature. This assessment may support stakeholders in the decision-making process regarding whether to further invest in fossil fuels or in renewable energies.

The thesis compares the economic and environmental benefits of wind power, PV and lignite and shows that, from a macroeconomic view, investing in renewable energies in the Aachen region is more beneficial than relying on conventional energy generation through fossil fuels. In a comparison of the economic and environmental economic 
effects, wind power and PV are the most cost-effective electricity generation sources when internalising the costs of GHG emissions and air pollution, as costs are 6.51 cent (c) per kWh electricity generated for wind power, $7.59 \mathrm{c} / \mathrm{kWh}$ for PV and $9.37 \mathrm{c} / \mathrm{kWh}$ for lignite. From a regional employment perspective, $\mathrm{PV}$ technology is the most beneficial electricity generation technology with a regional employment of 0.63 person years per GWh of electricity generated, which is four times higher than for lignite ( 0.17 person years per GWh) and 8 times higher than for wind power ( 0.08 person years per $\mathrm{GWh}$ ). The net positive effects that are illustrated validate renewable energy sources for those in the sector who are seeking evidence concerning the soundness of investing in renewables and clear statements for those arguing that the energy transition may be too cost intensive, as macroeconomic benefits prevail.

A limitation of this research lies in the fact that, even though the macroeconomic benefits of renewable energies over lignite are demonstrated and the energy transition is supported, the thesis does not assess potential job profiles for people who are currently employed in the fossil fuel sector and are affected by a phase-out of fossil fuels. In addition, the thesis does not include the costs and economic effects of the electricity storage that is needed in the long term if baseload fossil energy generation technologies are substituted by variable or intermittent energy generation technologies.

In spite of decisive factors such as the physical geographical potential, available spaces for development and the economic and environmental benefits that provide excellent conditions for further renewable energy developments, the district of Aachen is lagging with respect to achieving its energy targets. Meeting the regional transition target of $75 \%$ of electricity demand generated by renewable energy sources by 2030 in the district of Aachen is, therefore, challenging and more progressive development is necessary to meet future demands. In the investigation, the struggle between conventional energy generation technologies and their environments composed by actors and institutions (i.e. the socio-technical regime) and the renewable energy developments (i.e. the sociotechnical niche) is analysed to provide a comprehensive assessment of factors that support the regional energy transition (RQ 4: How can a regional energy transition be supported?). This contributes to the literature in the field which insufficiently takes the regional characteristics of both the conventional energy generation system and renewable energies into account. By closing this literature gap, the thesis emphasises the need for more specific analyses on the regional scale instead of merely focusing on the national perspective. 
The thesis finds that, in the past (mainly since the 1990s), a struggle took place in the Aachen region between the incumbent conventional energy generation regime and the evolving renewable energy niche, both constituted by technologies, actors and institutions. It also illustrates that the rise of renewable energies in the region was caused by informal institutions such as environmental concerns and a culture that embraced innovative technologies, which prevailed against the resistance of the conventional energy generation regime. Recently, we observe a decreasing acceptance of the fossil energy generation regime, inspired by widespread public concerns regarding environmental damages caused by the fossil fuel industry. This creates a window of opportunity for alternative methods of developing renewable energies in the region. This example illustrates the significance of having informal institutions as supporting elements in addition to looking at decisive factors such as technical feasibility as well as economic and environmental benefits. By further nurturing environmental awareness and a culture of embracing new technological opportunities such as, for example, the prosumption (production by consumers) of electricity or experimenting with technological solutions in the fields of grid and storage, the region might be able to manage its transition even more efficiently. By considering technologies, actors and institutions of renewable and conventional energies, the thesis presents a systemic and comprehensive approach for analysing the supportive factors of a regional energy transition that is transferable to other regions as well. This may serve as an exemplary in-depth analysis, first for investigating challenges and in a second step for formulating targeted approaches on regional scales. A shortcoming of the research with respect to the targets of the Aachen region lies in the fact that it focuses on electricity generation only, without taking energy efficiency or other sectors such as transport or heat generation into account. Furthermore, since the regional characteristics of the niche and the regime are evaluated for the Aachen region, the individual supportive factors of the regional energy transition are limited to a specific regional context. However, in other regions or countries, the tradeoff between investing in fossil fuels or renewable energies may depend on other parameters, which could be assessed individually (see Section 6.2).

To conclude, the thesis contributes to the scientific energy transition debate and creates an understanding of the geographic variation of individual regional transitions by positioning regions in the centre of the analysis. Disciplinary, it contributes to regional economics, environmental economics, transition management, the geography of sustainability transitions (GOST), and economic geography, as well as regional policy design, and opts for a multidimensional and systemically integrated approach to manage energy transitions successfully. 


\subsection{Policy implications}

The results provide a sound base for decision makers to opt for a phase-out of fossil fuels and develop renewable energies instead. While from an employment perspective PV is more beneficial, the development of wind power is more efficient from an environmental perspective in the district of Aachen. Given its energy intensity, wind power is, moreover, an essential source for achieving the regional energy targets. Therefore, a regional energy policy should include a balanced renewable energy mix by considering economic and environmental benefits fairly.

A cost-effectiveness of wind and PV compared to lignite is accomplished by taking the external costs of GHG emissions and air pollution into account. In this regard, rising energy costs may not be perceived solely as a threat to economic competitiveness but as a macroeconomic necessity to account for environmental damages. Against this background, it should be considered that global warming is naturally globally occurring phenomenon. Therefore, a worldwide strategy is needed to develop solutions for this global challenge. Internalising the avoided external costs of fossil fuels is a useful approach that builds on the price sensitivity of consumers and makes investments in conventional energy generation technologies unprofitable. However, an internalisation should be implemented on a global scale. This ensures that countries may not be able to provide comparative advantages through lax environmental regulations enabling comparatively lower electricity prices that may lead to a relocation of energy intensive industries, a phenomenon known as carbon leakage (Babiker, 2005; Peters, 2010).

Clearly, an essential pillar of energy transition includes the phase-out of conventional energy generation sources and an increasing use of energy generated by renewable sources instead. In countries such as Germany, we observe new market entrants such as private persons or newly established corporations generating electricity through renewable energy sources. These competitors challenge incumbent energy generation companies (e.g. RWE and E.ON), as the latter fear erosion of their usual business models of selling energy, which traditionally are generated by conventional energy sources. Conventional energy generation companies, therefore, have to adapt their old-fashioned business models by switching to renewable energy sources and/ or integrating energy services such as energy efficiency services or leasing models for renewable energy plants into their business strategies, to cope with the new market environment. Furthermore, research and politics need to find and create new employment opportunities for people working in conventional energy industries such as mining or power plant operations. Hence, investment in education and training are needed. 
Technological feasibility and economic and environmental benefits alone do not sufficiently push the development of renewable energies in a region. In addition, considering the supporting formal and informal institutions in a region allows for the development of more efficient policy design for transformations. In the case of the Aachen region, for example, a constant monitoring of the state of the energy transition, as it makes the technical process of energy generation more visible, builds on the technological enthusiasm in the region. This may also serve as a strategy in other regions with similar characteristics in terms of technological enthusiasm, such as the South German federal state of Baden-Württemberg where a lot of manufacturing enterprises and research institutes are situated.

In other regions, the situations may be different. In the Lausitz mining region in Central Germany, for example, the energy transition is seen as being more critical because the regional economy is more dependent on lignite mining and energy generation. Various employment opportunities do not exist for people employed in the fossil energy industry as in the case of the Aachen region, which is situated in the economically strong Rhineland region. Furthermore, especially in the eastern parts of Germany, there are fears of de-industrialisation, since after the reunification many enterprises were closed. Therefore, employees of the fossil fuel industry opposed the phase-out of fossil fuels, and politicians demanded large structural programmes and subsidies (rbb, 2019; Siegel, 2018). These subsidies and programmes support the development of new technologies and industries to become a smart region that is based on information and communications technology (ICT) (BMWi, 2020). By contrast, the federal state of Schleswig-Holstein, an economically less favoured region because of structural changes in the shipbuilding and marine industries (Forschungsstelle für regionale Zeitgeschichte und Public History, 2016), has no mining heritage. In this context, renewable energies are regarded by decision makers as being an opportunity for new regional economic development. These two examples are different from the Aachen context. In the Aachen region, the threat of job losses does not have such severe impacts on the regional economy as is the case in the Lausitz mining region, which depends much more heavily on mining and energy generation. By placing strong emphasis on education, research and development, the Aachen region has even been presented as an example of a successful economic transformation after black coal mining ended in the late 1990s (ARD, 2018). In contrast to the example of Schleswig-Holstein, where the wind power industry and wind power generation are comparatively new opportunities for the regional economy, the example of the Aachen region illustrates a specialisation in the energy sector, which shifted from mining and energy generation to research and development and currently focuses 
on grid, storage and e-mobility. Therefore, in the policy design process, the individual regional situation should be taken into account.

In the process of the energy transition such as, for example, in the case of Germany, debates focus mainly on the transformation of the electricity sector (Ekardt, 2014; Maubach, 2015). However, transportation and especially the heating and cooling sector are neglected. This occurs even though the heating and cooling sector's share in the amount of energy consumption is $49 \%$, much larger than that of the electricity sector (21\%) in Germany in 2018 (Agentur für Erneuerbare Energien, 2019). In addition to existing strategies and concepts targeting these sectors individually, a systemic approach and a combination of technologies across sectors are needed, such as using electricity to generate heat or for e-mobility, which may reduce the amount of storage capacity required for electricity generated by renewable energies. This is known as an integrated energy system (Sektorenkopplung in German) (Gils et al., 2016; Sterner et al., 2017). With respect to such systems, the use of ICT (e.g. the Internet of things (IOT) applied in concepts such as smart home or smart grid) may be an essential pillar of these strategies to monitor and operate such systems efficiently (Liggesmeyer et al., 2018; Weigel and Fischedick, 2018). Indeed, making full use of the existing technological potential in the field of integrated energy requires extensive coordination among stakeholders across the different sectors.

As the benefits of renewable energies are well studied, there is a need to integrate their further development into policy design and to decide on their implementation. The latter is of the utmost importance since even though a lot of policy recommendations and measures are available these are not being put into practice (Rickards et al., 2014). This process could strongly benefit through support from practical research in the field.

\subsection{Recommendations for further research}

Most regional economic impact studies consider only the economic effects of renewable energy developments and lack comprehensive analysis because they neglect other macroeconomic benefits such as avoided GHGs or air pollution leading to enhanced public health. In their turn, most studies of the environmental impacts neglect the positive economic effects of renewable energy developments.

In this regard, an integrated approach combining the evaluation of regional economic impacts with an assessment of the environmental benefits of renewable energy technologies has so far rarely been carried out in scientific studies. However, there 
is a strong need for integrated future research to raise public awareness and gain experience from additional regions. As a consequence, more interdisciplinary studies are required to enable a more complete view of the effects of developing renewable energies. Investigating these effects simultaneously allows for a more comprehensive indication of the total benefits of renewable energy developments.

The phase-out of fossil fuels and rising amounts of electricity generated through renewable energy sources require large-scale electricity storage capacities. Therefore, future research on renewable energies should also take into account the costs and the overall economic effects of the storage of electricity generated by renewable energy sources.

On a spatial scale, the implementation of renewable energies follows different paths. While we see dynamic and progressive developments in some regions, the deployment of renewable energy technologies is far beyond the potential of others. This may, on the one hand, be attributable to frequently identified causes such as, such as economic potentials (Slattery et al., 2011; Mulvaney et al., 2013) or environmental benefits (Yuan et al., 2015; Fokaides et al., 2014). However, more distinguished regional factors, including informal institutions involving cultures or norms, may also determine the implementation path, as illustrated in the case of the Aachen region. As decisions regarding developments take place on regional scales in most OECD countries, more in-depth analyses of regional situations are needed. Concepts such as multiscalarity and spatial endowment, which are introduced in Chapter 5, underline the significance of space and scale as well as the need to take individual regional situations into account, especially in pluralistic societies where decisions are taken democratically. Putting regions at the centre of the analysis allows for a better understanding of (national) transition processes. To conclude, there is a need for further research on regional transitions.

The concepts and frameworks that have been applied, such as the MLP, and which may offer support in assessing the energy transitions have so far been applied primarily in HDCs, as most concepts originate from such countries (Gosens et al., 2013). However, these concepts may also be useful in the context of developing countries and emerging economies that have increasing energy demands. Therefore, there is a need to assess how to overcome barriers to renewable energies, especially in this group of countries (as done by Luthra et al., 2015 for the case of India or by Ohunakin et al., 2014 for Nigeria). Of particular note is the case study in an HDC that Chapter 5 illustrates, showing that informal institutions can hamper or support the implementation and development of renewable energies. The role of informal institutions may be even 
more pertinent to decision-making in less developed countries that lack formal institutions, especially if informal institutions are used as substitutes for these (Meagher, 2007; Steer and Sen, 2010). As there is a lack of studies analysing renewable energy implementation in developing and emerging economies while using concepts such as MLPs, further research is needed into applying these methodologies to gain a better understanding of transition processes in these countries (Binz et al., 2020). A special focus on informal institutions may be a promising approach for understanding the dispersion of cleantech more thoroughly within this context.

Finally, it is the responsibility of the scientific community to evaluate statements about the benefits of measures to mitigate climate change in a comprehensive manner by providing scientific data and facts, enabling decision makers to make sound decisions regarding the transformation of our energy systems. 


\section{References}

A Renewable America, editor. Powering up Washington: A Report on the Economic Benefits of Renewable Electricity Development. Washington, DC: A Renewable America; 2015.

Aachener Nachrichten, editor. Bergheim: 3000 Beschäftigte demonstrieren gegen Kohle-Aus: Der Protest einer genervten Industrie. In: Aachener Nachrichten 01/12/2017, https://www. aachener-nachrichten.de/nrw-region/3000-beschaeftigte-demonstrieren-gegen-kohleaus-der-protest-einer-genervten-industrie_aid-24959295; 2017 [accessed 08 August 2019].

Aachener Nachrichten, editor. Hambacher Forst: Bereits 44 Baumhäuser abgebaut. In: Aachener Nachrichten 24/09/2018, https://www.aachener-nachrichten.de/nrw-region/hambacherforst-raeumung-geht-weiter_aid-33231951; 2018 [accessed 08 August 2019].

Aachener Zeitung, editor. Hambacher Forst - RWE stimmt Rodungsstopp bis Herbst 2020 zu. In: Aachener Zeitung 20.02.2019, https://www.aachener-zeitung.de/nrw-region/rwe-stimmtmoratorium-fuer-hambacher-forst-bis-herbst-2020-zu_aid-36898037; 2019a [accessed 08 August 2019].

Aachener Zeitung, editor. Wirtschaftsverbände warnen vor teurem Kohleausstieg. In: Aachener Zeitung 15/02/2019, https://www.aachener-zeitung.de/nrw-region/braunkohle/ wirtschaftsverbaende-warnen-vor-teurem-kohleausstieg_aid-35670163; 2019b [accessed 08 August 2019].

Ackerman F, Stanton E. Climate risks and carbon prices. Revising the social cost of carbon. Economics. The Open-Access, Open-Assessment E-Journal 2012;10;1-25.

Agentur für Erneuerbare Energien, editor. Aachen und Aalen - Stadt und Werk. In: KOMM:MAG - Das Jahresmagazin zu Erneuerbaren Energien in Kommunen 2014;8-11, https://www. unendlich-viel-energie.de/media/file/287.KOMM-MAG_2014_web.pdf; 2014a[accessed 11 April 2018].

Agentur für Erneuerbare Energien, editor. Akteure der Energiewende - Großteil der Erneuerbaren Energien kommt aus Bürgerhand. In: Renews Kompakt 29/01/2014. https:// www.unendlich-viel-energie.de/media/file/284.AEE_RenewsKompakt_Buergerenergie. pdf; 2014b [accessed 08 August 2019].

Agentur für Erneuerbare Energien, editor. Repräsentative Umfrage: 95 Prozent der Deutschen wollen mehr Erneuerbare Energien, https://www.unendlich-viel-energie.de/themen/ akzeptanz-erneuerbarer/akzeptanz-umfrage/akzeptanzumfrage2017; 2017 [accessed 08 August 2019]. 
Agentur für Erneuerbare Energien, editor. Endenergieverbrauch in Deutschland im Jahr 2018 nach Strom, Wärme und Verkehr, https://www.unendlich-viel-energie.de/mediathek/ grafiken/endenergieverbrauch-nach-strom-waerme-und-verkehr; 2019 [accessed 31 March 2020].

Agentur für Erneuerbare Energien, editor. Windenergie in Deutschland und seinen Bundesländern, https://www.foederal-erneuerbar.de/auf-einen-blick-detailseite/items/ windenergie-in-deutschland-und-seinen-bundeslaendern; s.a.a [accessed 31 March 2020].

Agentur für Erneuerbare Energien, editor. Landesinfo, https://www.foederal-erneuerbar.de/ landesinfo/bundesland/NI/kategorie/solar/auswahl/813-durchschnittliche_ja/\#goto_813; s.a.b [accessed 29 December 2017].

Agentur für Erneuerbare Energien, editor. Landesinfo, https://www.foederal-erneuerbar.de/ landesinfo/bundesland/BW/kategorie/solar/auswahl/813-durchschnittliche_ja/\#goto_813; s.a.c [accessed 29 December 2017].

Agentur für Erneuerbare Energien, editor. Förderal Erneuerbar - Bundesländer mit neuer Energie, https://www.foederal-erneuerbar.de/landesinfo/bundesland/BY/kategorie/solar/ auswahl/183-installierte_leistung\#goto_183; s.a.d [accessed 08 February 2018].

AGIT, editor. Technologieregion Aachen, https://www.agit.de/de/technologieregion-aachen. html; s.a. [accessed 08 August 2019].

Algoso D, Rusch E. Renewables Work: Job Growth from Renewable Energy Development in the Mid-Atlantic. Trenton, NJ: NJPIRG Law and Policy Center; 2004.

Allan GJ, Bryden I, McGregor PG, Stallard T, Swales JK, Turner K, Wallace R. Concurrent and legacy economic and environmental impacts from establishing a marine energy sector in Scotland. Energy Policy 2008;36:2734-2753.

Allan GJ, Lecca P, McGregor PG, Swales, JK. The economic impacts of marine energy developments: a case study from Scotland. Marine Policy 2014;43:122-131.

Amin A. An institutionalist perspective on regional economic development. International Journal of Urban and Regional Research 1999;23:365-378.

Andrews M, Squire C, Tamboukou M, editors. Doing narrative research. Los Angeles, CA, London, New Delhi, Singapore, Washington, DC: Sage; 2013.

ARD, editor. Laschet zum Steinkohle-Aus „Ein wehmütiger Tag“, https://www.tagesschau.de/ inland/laschet-interview-steinkohle-101.html; 2018 [accessed 08 August 2019]. 
ARD, editor. Kohlekommission - Hambacher Forst soll bleiben. In: Tagesschau 26/01/2019, https://www.tagesschau.de/inland/kohle-hambacherforst-101.html; 2019 [accessed 08 August 2019].

Aretz A, Heinbach K, Hirschl B, Schröder A. Wertschöpfungs- und Beschäftigungseffekte durch den Ausbau Erneuerbarer Energien. Hamburg: Greenpeace e.V.; 2013.

$A R L$, editor. Kommunale Planungshoheit, https://www.arl-net.de/lexica/de/kommunaleplanungshoheit; s.a. [accessed 13 October 2017].

Arnold N, Gufler K, Sholly S, Müllner N. Mögliche radiologische Auswirkungen eines Versagens des Reaktordruckbehälters des KKW Tihange 2. Wien: Universität für Bodenkultur Wien; s.a.

Asheim BT, Boschma R, Cooke P. Constructing regional advantage: Platform policies based on related variety and differentiated knowledge bases. Regional Studies 2011;45:893-904.

Audretsch DB. Technological regimes, industrial demography and the evolution of industrial structures. Industrial and Corporate Change 1997;6:49-82.

Babatunde KA, Begum RA, Said FF. Application of computable general equilibrium CGE to climate change mitigation policy: A systematic review. Renewable and Sustainable Energy Reviews 2017;78: 61-71.

Babiker MH. Climate change policy, market structure, and carbon leakage. Journal of international Economics 2005;65:421-445.

Bastianoni S, Pulselli FM, Tiezzi E. The problem of assigning responsibility for greenhouse gas emissions. Ecological Economics 2004;49:253-257.

Bateman IJ, Day BH, Argarwala M, Bacon P, Bad'ura T, Binner A, De-Gol AJ, Ditchburn B, Dugale S, Emmett B, Ferrini S, Fezzi C, Harwood A, Hillier J Hiscock K, Hulme M, Jackson B, Lovett A, Mackie E, Matthews R, Sen A, Siriwardena G, Smith P, Snowdon P, Sünnenberg G, Vetter S, Vinjili S. UK National Ecosystem Assessment Follow-on Work Package Report, 3 Economic value of ecosystem services, http://uknea.unep-wcmc.org/LinkClick. aspx?fileticket=1n4oolhlksY\%3D\&tabid=82; 2014 [accessed 08/02/2018].

BDB, editor. Betreiber-Datenbasis (BDB): Stand Januar 2015. Rade; 2015. Retraction in: Leipziger Institut für Energie, editor. Marktanalyse - Windenergie an Land, http://www.bmwi.de/ Redaktion/DE/Downloads/S-T/studie-windernergie-an-land.html; 2015 [accessed 29 December 2017].

Beckmann KJ, Gailing L, Hülz M, Kemming H, Leibenath M, Libbe J, Stefansky A. Räumliche Implikationen der Energiewende Positionspapier. Berlin: Difu; 2013. 
Belz FM. A transition towards sustainability in the Swiss agri-food chain (1970-2000): using and improving the multi-level perspective. In: Elzen B, Geels FW, Green K, editors. System innovation and the transition to sustainability. Cheltenham, Northampton, MA: Edward Elgar; 2004. p. 97-114.

Benz A, Fürst D, Kilper H, Rehfeld D. Regionalisierung: Theorie-Praxis_Perspektiven. Wiesbaden: Springer; 1999.

Bergbaumuseum Grube Anna e.V., editor. Grube Anna Bergbaumuseum, http://www. bergbaumuseum-grube-anna2.de/; s.a. [accessed 08 February 2018].

Bergs C, Peichl A. Numerische Gleichgewichtsmodelle - Grundlagen und Anwendungsbeispiele. Köln: Finanzwissenschaftliches Forschungsinstitut Universität zu Köln; 2006.

Bezdek RH. Renewable energy and energy efficiency: Economic drivers for the 21st century. Boulder, CO: American Solar Energy Society; 2007.

Bilbao-Ubillos J. The limits of Human Development Index: The complementary role of economic and social cohesion, development strategies and sustainability. Sustainable Development 2013;21:400-412.

Binz C, Tang T, Huentele J. Spatial lifecycles of cleantech industries - The global development history of solar photovoltaics. Energy Policy 2017a;101:386-402.

Binz C, Truffer B. Global Innovation Systems-A conceptual framework for innovation dynamics in transnational contexts. Research Policy 2017b;46:1284-1298.

Binz C, Coenen L, Murphy JT, Truffer B. Geographies of transition- From topical concerns to theoretical engagement: A commentary on the transitions research agenda. Environmental Innovation and Societal Transitions 2020;34:1-3.

Black and Veatch, editors. Economic impact of Renewable Energy in Pennsylvania. Overland Park, KS: Black and Veatch; 2004.

BMU, editor. Vergütungssätze, Degression und Berechnungsbeispiele nach dem ErneuerbareEnergien-Gesetz. https://www.erneuerbare-energien.de/EE/Redaktion/DE/Downloads/ Broschue-re/ verguetungssaetze-eeg-2012.pdf?__\%20blob=publicationFile\&v=3; 2013 [accessed 19 June 2016].

BMU, editor. Der Klimaschutzplan 2050 - Die deutsche Klimaschutzlangfriststrategie, https://www.bmu.de/themen/klima-energie/klimaschutz/nationale-klimapolitik/ klimaschutzplan-2050/\#c8420; 2017a [accessed 08 August 2019]. 
BMU, editor. Das 3x3 einer guten Öffentlichkeitsbeteiligung bei Großprojekten - Status-quo und Perspektiven. Dessau-Roßlau: Umweltbundesamt; 2017b.

BMVBS, editor. Strategische Einbindung regenerativer Energien in regionale Energiekonzepte Wertschöpfung auf regionaler Ebene, http://www.bbsr.bund.de/cln_032/nn_21684/BBSR/DE/ Veroeffentlichungen/BMVBS/Online/2011/ON182011.html; 2011 [accessed 29 December 2017].

BMVBS, editor. Regionalwirtschaftliche Effekte der erneuerbaren Energien II - Einfluss der Regionalplanung und Raumordnung auf regionale Wertschöpfung. Bonn: BMVBS; 2013.

BMVI, editor. Räumlich differenzierte Flächenpotentiale für erneuerbare Energien in Deutschland, http://www.bbsr.bund.de/BBSR/DE/Veroeffentlichungen/BMVI/ BMVIOnline/2015/DL_BMVI_Online_08_15.pdf?_blob\%20=publicationFile\&v=2; 2015 [accessed 29 December 2017].

BMWi, editor. Erneuerbare Energien in Zahlen - Nationale und internationale Entwicklung im Jahr 2015. Berlin: BMWi; 2016.

BMWi, editor. Modellvorhaben „Unternehmen Revier", https://www.bmwi.de/Redaktion/DE/ Textsammlungen/Energie/modellvorhaben-unternehmen-revier.html; 2020 [accessed 31 March 2020].

Böckers V, Giessing L, Rösch J. The Green Game Changer: An Empirical Assessment of the Effects of Wind and Solar Power on the Merit Order. Düsseldorf: Düsseldorf University Press; 2013.

Böhmer M, Kircher A, Hobohm J, Weiß J, Piegsa A. Wertschöpfungs- und Beschäftigungseffekte der Energiewirtschaft: Studie im Auftrag des Bundesministeriums für Wirtschaft und Energie. München, Basel, Berlin: Prognos; 2015.

Böhringer C, Löschel A. Computable general equilibrium models for sustainability impact assessment: Status quo and prospects. Ecological Economics 2006;60:49-64.

Böhringer C, Rutherford TF, Wiegard W. Computable general equilibrium analysis: Opening a black box. Heidelberg: ZEW; 2003.

Bolton R, Foxon T. A socio-technical perspective on low carbon investment challenges-insights for UK energy policy. Environmental Innovation and Societal Transitions 2015;14:165-181.

Bonnemaison T, Lasseur M, Thibault C. La géographie culturelle: Cours de l'université Paris IV Sorbonne, 1994-1997. Paris: Comité des travaux historiques et scientifiques; 2005.

Bost M, Böther T, Hirschl B, Kreuz S, Neumann A, Weiß J. Erneuerbare Energien Potenziale in Brandenburg 2030: Erschließbare technische Potenziale sowie Wertschöpfungs- und Beschäftigungseffekte - eine szenariobasierte Analyse. Berlin: IÖW; 2012. 
Brachert M, Titze M. Wirtschaftsstruktur und Regionalentwicklung: Zur Bedeutung von Headquartern und verbundenen Wirtschaftszweigen. Wirtschaft im Wandel 2012;18:209-216.

Breitschopf B, Nathani C, Resch G. Review of approaches for employment impact assessment of renewable energy deployment. Economic and industrial development (EID)-EMPLOY, Final report, http://iea-retd.org/wp-content/uploads/2011/11/EMPLOY-task-1.pdf; 2011 [accessed 29 December 2017].

Bridge G, Bouzarovski S, Bradshaw M, Eyre N. Geographies of energy transition: Space, place and the low-carbon economy. Energy Policy 2013;53:331-340.

Bröcker J, Burmeister J, Preißler-Jebe JH, Alberty F. Wertschöpfungs- und Beschäftigungseffekte als Folge des Ausbaus Erneuerbarer Energien in Schleswig-Holstein. Kiel: Universität Kiel Institut für Regionalforschung; 2014.

Brown LA, Holmes J. The delimitation of functional regions, nodal regions, and hierarchies by functional distance approaches. Ekistics 1971;32:387-391.

Brücher W. Erneuerbare Energien in der globalen Versorgung aus historisch-geographischer Perspektive. Geographische Rundschau 2008;60:4-12.

Brunnengräber A. Klimaskeptiker in Deutschland und ihr Kampf gegen die Energiewende. Berlin: Freie Universität Berlin, Forschungszentrum für Umweltpolitik; 2013.

BUND, NABU, editors. Praxisbeispiele Windenergie \& Artenschutz - Erfolgreiche, Erfolg versprechende \& innovative Ansätze. 2nd ed. Stuttgart: BUND, NABU; 2017.

Bundesagentur für Arbeit, editor. Statistik der Bundesagentur für Arbeit - Betriebe, Ausbildungsbetriebe und ihre Beschäftigten. Düsseldorf: Statistik Service West (unpublished); 2017.

Bundesagentur für Arbeit, editor. Betriebe, Ausbildungsbetriebe und ihre Beschäftigten. Düsseldorf: Bundesagentur für Arbeit Statistik-Service West; 2018.

Bundesanzeiger Verlag $\mathrm{GmbH}$, editor. Unternehmensregister. https://www. unternehmensregister. de/ureg/index.html?dest=ureg\&language=de; s.a. [accessed 08 February 2018].

Bundesministerium der Finanzen, editor. Lohn- und Einkommenssteuerrechner, https://www. bmf-steuerrechner.de/fb2016/?clean=true; 2016 [accessed 30 July 2016].

Bundesministerium der Finanzen, editor. Solidaritätszuschlag, https://www. bundesfinanzministerium .de/Content/DE/Glossareintraege/S/Solidaritaetszuschlag. html?view=renderHelp; s.a.a [accessed 08 February 2018]. 
Bundesministerium der Finanzen, editor. BMF Dokumentation - Der Gemeindeanteil an der Einkommenssteuer in der Gemeindefinanzreform, http://www.bundesfinanzministerium. de/ Content/DE/Standardartikel/Themen/Oeffentliche_Finanzen/Foederale_ Finanzbeziehungen/Kommunalfinanzen/GemeindeanteilESt-2015.pdf?__ blob=publicationFile\&v=2; s.a.b [accessed 08 February 2018].

Bundesministerium der Justiz und für Verbraucherschutz, editor. Gesetz für den Ausbau erneuerbarer Energien (Erneuerbare-Energien-Gesetz - EEG 2014) § 61 EEG-Umlage für Letztverbraucher und Eigenversorger, https://www.gesetze-im-internet.de/ eeg_2014/_61.html; s.a.a [accessed 08 February 2018].

Bundesministerium der Justiz und für Verbraucherschutz, editor. Solidaritätszuschlagsgesetz 1995 (SolzG 1995) §3 Bemessungsgrundlage und zeitliche Anwendung, http://www. gesetze-im-internet.de/solzg_1995/_3.html; s.a.b [accessed 11 April 2018].

Bundesministerium der Justiz und für Verbraucherschutz, editor. Sozialgesetzbuch (SGB) Fünftes Buch (V) - Gesetzliche Krankenversicherung - (Artikel 1 des Gesetzes v. 20. Dezember 1988, BGBI. I S. 2477)§ 241 Allgemeiner Beitragssatz, http://www.gesetze-iminternet.de/sgb_5/__241.html; s.a.c [accessed 11 April 2018].

Bundesministerium der Justiz und für Verbraucherschutz, editor. Sozialgesetzbuch (SGB) Drittes Buch (III) - Arbeitsförderung - (Artikel 1 des Gesetzes vom 24. März 1997, BGBI. I S. 594) § 341 Beitragssatz und Beitragsbemessung, http://www.gesetze-im-internet.de/sgb_3/__341. html; s.a.d [accessed 11 April 2018].

Bundesministerium der Justiz und für Verbraucherschutz, editor. Sozialgesetzbuch (SGB) - Elftes Buch (XI) - Soziale Pflegeversicherung (Artikel 1 des Gesetzes vom 26. Mai 1994, BGBI. I S. 1014)§55 Beitragssatz, Beitragsbemessungsgrenze, http://www.gesetze-im-internet.de/ sgb_11/_55.html; s.a.e [accessed 11 April 2018].

Bundesministerium der Justiz und für Verbraucherschutz, editor. Gewerbesteuergesetz (GewStG) § 11 Steuermesszahl und Steuermessbetrag. http://www.gesetze-im-internet. de/gewstg/__11.html; s.a.f [accessed 11 April 2018].

Bundesministerium der Justiz und für Verbraucherschutz, editor. Gewerbesteuergesetz (GewStG) § 16 Hebesatz, http://www.gesetze-im-internet.de/gewstg/__16.html; s.a.g [accessed 11 April 2018].

Bundesministerium für Arbeit und Soziales, editor. Bekanntmachung der Beitragssätze in der allgemeinen Rentenversicherung und der knappschaftlichen Rentenversicherung für das Jahr 2016, http://www.bgbl.de/xaver/bgbl/start.xav?startbk=Bundesanzeiger_ BGBI\&jumpTo = bgbI115s2110a.pdf\#__bgbI__\%2F\%2F*\%5B\%40attr_ id\%3D\%27bgbl115s2110a.pdf\%27\%5D__1477913096284; 2015 [accessed 11 April 2018]. 
Bundesnetzagentur, editor. Leitfaden zur Eigenversorgung, https://www.bundesnetzagentur. de/SharedDocs/Downloads/DE/Sachgebiete/Energie/Unternehmen Institutionen/ErneuerbareEnergien/Eigenversorgung/Finaler_Leitfaden.pdf; jsessionid=C79C6107CA42A3A00E9D30BE5F47BD0C?__blob=publicationFile\&v=2; 2016 [accessed 08 February 2018].

Bundesnetzagentur, editor. Photovoltaikanlagen - Datenmeldungen und EEG-Vergütungssätze, https.//wwwbundesnetzagenturde/DE/Sachgebiete/ElektrizitaetundGas/Unternehmen_ Institutionen/ErneuerbareEnergien/Photovoltaik/DatenMeldgn_EEG-VergSaetze/ DatenMeldgn_EEG-VergSaetze_nodehtml; 2017a [accessed 23 March 2017].

Bundesnetzagentur, editor. Ausschreibung zur Ermittlung der finanziellen Förderung von Windenergieanlagen an Land, https://www.bundesnetzagentur.de/DE/Sachgebiete/ ElektrizitaetundGas/Unternehmen_Institutionen/Ausschreibungen/Wind_Onshore/ Wind_Onshore_node.html; 2017b [accessed 11 April 2018].

Bundesnetzagentur, editor. Ergebnisse der zweiten Ausschreibung für Wind an Land, https:// www.bundesnetzagentur.de/SharedDocs/Pressemitteilungen/DE/2017/15082017_ WindAnLand.html; 2017c [accessed 11 April 2018].

Bundesnetzagentur, editor. EEG-Registerdaten und EEG Fördersätze, https://www.bundesnetzagentur.de/SharedDocs/Downloads/DE/ Sachgebiete/Energie/Unternehmen_Institutionen/ErneuerbareEnergien/ ZahlenDatenInformationen/VOeFF_Registerdaten/2018_01_Veroeff_RegDaten. xlsx;jsessionid=342ADC618D4907A1EC518CBE511FCE75?__blob=publicationFile \&v=2; 2018 [accessed 11 April 2018].

BWE, editor. Potenzial der Windenergienutzung an Land - Kurzfassung, https://www. wind-energie.de/sites/default/files/download/publication/studie-zum-potenzialder-windenergienutzung-land/bwe_potenzialstudie_kurzfassung_2012-03.pdf; 2012 [accessed 29 December 2017].

BWE, editor. Die "Großen Vier" dominieren deutschen Onshoremarkt. https://www. windindustrie-in-deutschland.de/fachartikel/die-grossen-vier-dominieren-deutschenonshoremarkt/; 2015 [accessed 11 April 2018].

BWE, editor. Das Erneuerbare-Energien-Gesetz (EEG 2017) vom 08.07.2016, https://www.windenergie.de/sites/default/files/download/publication/das-erneuerbare-energien-gesetzeeg-2017-vom-08072016/20160921_bwe_informationspapier_eeg_2017_final.pdf; 2016a [accessed 11 April 2018].

BWE, editor. Windindustrie in Deutschland. Berlin: Bundesverband WindEnergie e.V.; 2016b. 
BWE, editor. Installierte Windenergieleistung in Deutschland, https://www.wind-energie.de/ infocenter/statistiken/deutschland/installierte-windenergieleistung-deutschland; 2017 [accessed 11 April 2018].

BWE, editor. Planung von Windenergieanlagen, https://www.wind-energie.de/themen/ mensch-und-umwelt/planung/; 2018 [accessed 06 December 2018].

Callen T. Gross Domestic Product: An Economy's All, http://www.imf.org/external/pubs/ft/ fandd/basics/gdp.htm; 2017 [accessed 29 December 2017].

Cansino JM, Cardenete MA, Gonzalez JM, Pablo-Romero MDP. Economic impacts of solar thermal electricity technology deployment on Andalusian productive activities: a CGE approach. The Annals of Regional Science 2013;50:25-47.

Cansino JM, Cardenete MA, González-Limón JM, Román R. The economic influence of photovoltaic technology on electricity generation: A CGE computable general equilibrium approach for the Andalusian case. Energy 2014;73:70-79.

Carbon Brief, editor. Paris 2015: Tracking country climate pledges, https://www.carbonbrief.org/ paris-2015-tracking-country-climate-pledges; s.a. [accessed 31 March 2020].

Carlson JL, Loomis DG, Payne J. An assessment of the economic impact of the wind turbine supply chain in Illinois. The Electricity Journal 2010;23:75-93.

Cerf M, Guillot MN, Olry P. Acting as a change agent in supporting sustainable agriculture: how to cope with new professional situations? Journal of Agricultural Education and Extension 2011;17:7-19.

Chen GQ, Chen ZM. Greenhouse gas emissions and natural resources use by the world economy: ecological input-output modelling. Ecological Modelling, 2011;222: 2362-2376.

Christ CF. A review of input-output analysis. In: National Bureau of Economic Research, editor. Input-output analysis: An appraisal. Princeton, NJ: Princeton University Press; 1955, p. 137-182.

Christian Münch GmbH, editor. Photovoltaik.org - Unabhängige Beratung, http://www. photovoltaik.org/photovoltaikanlagen/; s.a. [accessed 28 July 2016].

Clearingstelle EEG, editor. Vergütungssätze und Degressionsbeispiele nach dem neuen Erneuerbare-Energien-Gesetz (EEG) vom 31. Oktober 2008 mit Änderungen vom 11. August 2010, https://www.clearingstelle-eeg-kwkg.de/files/eeg_2009_verguetungsdegression_ Aenderungen_100811_bmu.pdf; s.a [accessed 08 February 2018].

Coenen L, Benneworth P, Truffer B. Toward a spatial perspective on sustainability transitions. Research Policy 2012;41:968-979. 
Coenen L, Truffer, B. Places and spaces of sustainability transitions: Geographical contributions to an emerging research and policy field. European Planning Studies 2012;20:367-374.

Colander D. Gross Output: A New Revolutionary Way to Confuse Students about Measuring the Economy. Eastern Economic Journal 2014;40:451-455.

Coon RC, Hodur NM, Bangsund DA. Renewable energy industries' contribution to the North Dakota economy. Fargo, ND: North Dakota State University; 2012.

Coon RC, Leistritz FL, Hertsgaard TA, Leholm AG. The North Dakota input-output model: A tool for analyzing economic linkages. Fargo, ND: North Dakota State University; 1985.

Coover A, Stafford ER, Hartman CL. An Analysis of State-Level Economic Impacts from the Development of Wind Power Plants in Cache County, Utah. Logan, UT: Utah State University; 2013.

Costanti M. Quantifying the economic development impacts of wind power in six rural Montana counties using NREL's JEDI model. Golden, CO: NREL; 2004.

Costello DM. A cross-country, cross-industry comparison of productivity growth. Journal of Political Economy 1993;101:207-222.

Crawford RH. Life cycle energy and greenhouse emissions analysis of wind turbines and the effect of size on energy yield. Renewable and Sustainable Energy Reviews 2009;9:26532660.

Crippa M, Oreggioni G, Guizzardi D, Muntean M, Schaaf E, Lo Vullo E, Solazzo E, MonfortiFerrario, F, Olivier JGJ, Vignati E. Fossil $\mathrm{CO}_{2}$ and GHG emissions of all world countries. Luxembourg: Publications Office of the European Union; 2019.

Cullen J. Measuring the Environmental Benefits of Wind-Generated Electricity. American Economic Journal: Economic Policy 2013;5:107-133.

Cylex International S.N.C., editor. Cylex-Branchenbuch Deutschland, http://web2.cylex.de/; s.a. [accessed 27 August 2015].

Dağaşan P, Schulz S, Trockel S. Das neue EEG 2014 - Was ändert sich? http://www.energiedialog. nrw.de/das-neue-eeg-2014-was-aendert-sich/; 2014 [accessed 11 April 2018].

de Arce R, Mahía R, Medina E, Escribano G. A simulation of the economic impact of renewable energy development in Morocco. Energy Policy 2012; 46:335-345.

de Paolo AF, Ribeiro EMS, Porto G. Mapping countries cooperation in photovoltaic technology development based on patent analysis, http://iamot2016.org/proceedings/\%20papers/ IAMOT_2016_paper_259.pdf; 2016 [accessed 23 March 2017]. 
DEBRIV, editor. Braunkohle in Deutschland 2005. Köln: DEBRIV; s.a.

del Río P, Burguillo M. Assessing the impact of renewable energy deployment on local sustainability: Towards a theoretical framework. Renewable and Sustainable Energy Reviews 2009;12:1325-1344.

Der Präsident des Landtags NRW, editor. Landtag NRW. https://www.landtag.nrw.de/portal/ WWW/home.jsp; s.a. [accessed 08 August 2019].

Destatis, editor. Verdienste und Arbeitskosten. https://www.destatis.de/DE/Publikatio-nen/ Thematisch/VerdiensteArbeitskosten/Arbeitnehmerverdienste/IndizesVerdiensteJ.html; 2016 [accessed 12 July 2016].

Destatis, editor. Bundesländer mit Hauptstädten nach Fläche, Bevölkerung und Bevölkerungsdichte am 31122015, im Juli 2017 wegen korrigierter Fläche revidiert, https:// www.destatis.de/DE/ZahlenFakten/LaenderRegionen/Regionales/Gemeindeverzeichnis/ Administrativ/Aktuell/02Bundeslaender.html; 2017 [accessed 08 February 2018].

Deutsche Bundesbank, editor. Devisenkursstatistik Stand vom 29.12.2017, https://www. bundesbank.de/Redaktion/DE/Downloads/Statistiken/Aussenwirtschaft/Devisen_Euro_ Referenzkurs/stat_eurorefj.pdf?__blob=publicationFile; 2017 [accessed 08 February 2018].

Deutsche Bundesbank, editor. GuV Statistik - Statistik der Gewinn und Verlustrechnungen der Banken, https://www.bundesbank.de/Navigation/DE/Statistiken/Banken_und_andere_ finanzielle_Institute/Banken/GuV_Statistik/guv_statistik.html; s.a.a [accessed 08 February 2018].

Deutsche Bundesbank, editor. Tabellen - Unternehmensabschlüsse, https://www. bundesbank.de/Navigation/DE/Statistiken/Unternehmen_und_private_Haushalte/ Unternehmensabschluesse/Tabellen/tabellen.html; s.a.b [accessed 08 February 2018].

Deutsche Windguard, editor. Kostensituation der Windenergie an Land in Deutschland. Varel: Deutsche Windguard; 2013.

Deutsche Windguard, editor. Kostensituation der Windenergie an Land in Deutschland Update. Varel: Deutsche Windguard; 2015.

Dewald U, Fromhold-Eisebith M. Trajectories of sustainability transitions in scale-transcending in-novation systems: The case of photovoltaics. Environmental Innovation and Societal Transitions 2015;17:110-125.

Dewald U, Truffer B. The local sources of market formation: explaining regional growth differentials in German photovoltaic markets. European Planning Studies 2012;20:397-420. 
Deyette J, Clemmer SL. Increasing the Texas renewable energy standard: Economic and employment benefits, https://www.ucsusa.org/clean_energy/smart-energy-solutions/ increase-renewables/increasing-the-texas.html\#.WkYVonkiFpj; 2005 [accessed 29 December 2017].

Deyette J, Clemmer SL. The Washington Clean Energy Initiative: Effects of I-937 on Consumers, Jobs and the Economy, https:/www.ucsusa.org/sites/default/files/legacy/assets/documents/ clean_energy/washington-i-937-report-final.pdf; 2006 [accessed 29 December 2017].

Dincer I. Renewable energy and sustainable development: a crucial review. Renewable and Sustainable Energy Reviews 2000;4:157-175.

Ding Z, Duan X, Ge Q, Zhang Z. Control of atmospheric $\mathrm{CO}_{2}$ concentrations by 2050: A calculation on the emission rights of different countries. Science in China Series D: Earth Sciences 2009;52:1447.

DIW, editor. Die ökonomische Bedeutung der Windenergiebranche - Windenergie an Land in Brandenburg Berlin: DIW Econ GmbH; 2014a.

DIW, editor. Die ökonomische Bedeutung der Windenergiebranche - Windenergie an Land in Deutschland und Nordrhein-Westfalen. Berlin: DIW Econ GmbH; 2014b.

DOE, editor. 20\% Wind Energy by 2030. Increasing Wind Energy's Contribution to US Electricity Supply, http://www.nrel.gov/docs/fy08osti/41869.pdf; 2008 [accessed 29 December 2017].

DOE, editor. 2014 Wind Technologies Market Report, https://energy.gov/sites/prod/ files/2015/08/f25/2014-Wind-Technologies-Market-Report-8.7.pdf; s.a. [accessed 02 January 2016].

Donner O. Wie viel Strom werden wir in der SR Aachen im Jahr 2030 verbrauchen? Ein mögliches Trendszenario, https://www.fiw.rwth-aachen.de/neo/fileadmin/pdf/render/161027_ Vortrag_render_Donner_website.pdf; 2016 [accessed 08 August 2019].

Dötsch C, Taschenberger J, Schönberg I. Leitfaden Nahwärme. Stuttgart: Fraunhofer IRB; 1998. dpa, editor. Kraftwerks-Zulieferer befürchten Jobverluste. In: Handelsblatt 29 March 2014; http:// www.handelsblatt.com/unternehmen/industrie/energiewende-kraftwerks-zuliefererbefuerchten-jobverluste/9687710.html; 2014 [accessed 11 April 2018].

DTI, editor. Renewable Supply Chain GAP analysis, http://webarchive.nationalarchives.gov.uk/+/ http:/www.dti.gov.uk/files/file15401.pdf; 2004. [accessed 29 December 2017].

Dunlap RE. Climate change skepticism and denial: An introduction. American Behavioral Scientist, 2013;57:691-698. 
Dunlap RE, McCright AM. Organized climate change denial. In: Dryzek JS, Norgaard RB, Schlosberg D, editors. The Oxford handbook of climate change and society. New York: Oxford University Press; 2011, p. 144-160.

E.ON SE, editor. Projektbeschreibung, http://m5bat.de/Projekt/Projektbeschreibung; 2017 [accessed 08 August 2019].

ECONorthwest, editor. Economic Impacts of Wind Power in Kittitas County. Portland, OR: ECONorthwest; 2002.

Edinger R. Distributed electricity generation with renewable resources: assessing the economics of photovoltaic technologies in vertically integrated and in restructured energy markets. Marburg: Tectum Verlag; 1999.

EEA, editor. Costs of air pollution from European industrial facilities 2008-2012 - an updated assessment Luxembourg. European Environmental Agency; 2014.

EEFA, editor. Bedeutung der rheinischen Braunkohle - sektorale und regionale Beschäftigungsund Produktionseffekte - Untersuchung im Auftrag der RWE Power AG. Münster, Berlin 2010: EEFA; 2010.

Eggers M, editor. Photovoltaikversicherung 24, https://www.photovoltaikversicherung24.de/; s.a. [accessed 25 July 2015].

EIA, editor. Future world energy demand driven by trends in developing countries, https://www. eia.gov/todayinenergy/detail.php?id=14011; 2013 [accessed 31 March 2020].

Ekardt F. Jahrhundertaufgabe Energiewende: Ein Handbuch. Berlin: Ch. Links Verlag; 2014.

Energy Hills e.V., editor. Who is Energy Hills?, http://www.energyhills.eu/index.php?who-is -energy-hills-1; 2017.

Enevoldsen P, Sovacool BK. Examining the social acceptance of wind energy: Practical guidelines for onshore wind project development in France. Renewable and Sustainable Energy Reviews 2016;53:178-184.

Engelbert J, Strothe L, Wachinger G, Wist SK, Nietgen T, Schaffrin A., Schlagwein W, Schulz M. Partizipationsmodell - Beteiligung an der Energiewende. Stuttgart: DIALOGIK; 2017.

EuPD Research, editor. Photovoltaik-Preismonitor Deutschland, https://www.solarwirtschaft.de/ fileadmin/media/pdf/130218_EuPD_Preismonitor_q1_13.pdf; 2013 [accessed 29 December 2017]. 
European Energy Exchange AG, editor. Ergebnisse EUA Primary Auction Spot - Download, https://www.eex.com/de/marktdaten/umweltprodukte/auktionsmarkt/europeanemission-allowances-auction/european-emission-allowances-auction-download; 2017 [accessed 08 February 2018].

Eurostat, editor. Electricity prices for domestic consumers - bi-annual data (from 2007 onwards), https://data.europa.eu/euodp/data/dataset/aqDMwMrWalVNy4eZt2rYOQ; 2015 [accessed 07 September 2015].

Eurostat, editor. Acidifying gas emissions, analysis by economic activity, EU-28, 2009 and 2014, http://ec.europa.eu/eurostat/statistics-explained/index.php/File:Figure-2-Acidifying_gas_ emissions,_analysis_by_economic_activity,_EU-28,_2009_and_2014_(\%25_of_total_ emissions_in_SO2_equivalents_.png; 2016 [accessed 11 April 2018].

Eurostat, editor. Geodata, http://ec.europa.eu/eurostat/web/gisco/geodata/reference-data; s.a.a [accessed 08 February 2018].

Eurostat, editor. NUTS - Nomenclature of territorial units for statistics, http://ec.europa.eu/ eurostat/web/nuts/; s.a.b [accessed 29 December 2017].

Eurostat, editor. NUTS - Systematik der Gebietseinheiten für die Statistik, http://ec.europa.eu/ eurostat/de/web/nuts/principles-and-characteristics; s.a.c [accessed 08 February 2018].

Evans A, Strezov V, Evans T. Assessment of sustainability indicators for renewable energy technologies. Renewable and Sustainable Energy Reviews 2009;13:1082-1088.

Fachagentur Windenergie an Land, editor. Status des Windenergieausbaus und Repowering in Schleswig-Holstein. Berlin: FA Wind; 2016.

Fachagentur Windenergie an Land, editor. Der rechtliche Umgang mit dem Landschaftsbild, https://www.fachagentur-windenergie.de/themen/landschaftsbild/rechtlicher-umgangmit-dem-landschaftsbild.html; 2018 [accessed 11 April 2018].

Faniran A. On the definition of planning regions: the case for river basins in developing countries. Singapore Journal of Tropical Geography 1980;1:9-15.

Fanning T, Jones $C$, Munday M. The regional employment returns from wave and tidal energy: A Welsh analysis. Energy 2014;76:958-966.

Faulin J, Lera F, Pintor JM, García J. The outlook for renewable energy in Navarre: an economic profile. Energy Policy 2006;34:2201-2216.

FGW, editor. FGW e.V. -Fördergesellschaft Windenergie und andere Dezentrale Energien. https://wind-fgw.de/; 2017a [accessed 07 April 2019]. 
FGW, editor. Referenzertragsverfahren. https://www.wind-fgw.de/wp-content/ uploads/2017/08/alte_Ref_ENERCON.pdf; 2017b [accessed 11 April 2018].

finanzen.net GmbH, editor. RWE Aktie, https://www.finanzen.net/aktien/RWE-Aktie; 2019 [accessed 08 August 2019].

Finus O, Lauerburg K, Pietz C, Schaubt M. Kommunale Investitionen in Erneuerbare Energien - Wirkungen und Perspektiven Birkenfeld, Radolfzell: DUH, IfaS; 2013.

Flauger J. Gabriel zeigt ein Herz für Braunkohle. In: Handelsblatt 02/05/2015, https://www. handelsblatt.com/politik/deutschland/energiepolitik-gabriel-zeigt-ein-herz-fuerbraunkohle/11590124.html?ticket=ST-45807108-ZjoU7PZ5wQwTmISEfO64-ap5; 2015 [accessed 31 March 2020].

Flauger J. Was Fukushima für die Atomkraft war, könnte der Hambacher Forst für die Kohle werden. In: Handelsblatt 07/10/2018, https://www.handelsblatt.com/meinung/ kommentare/kommentar-was-fukushima-fuer-die-atomkraft-war-koennteder-hambacher-forst-fuer-die-kohle-werden/23156940.html?ticket=ST-130249A7MpgxMx01TThJO6Lpwa-ap1; 2018 [accessed 08 August 2019].

Flegg AT, Tohmo T. Regional input-output tables and the FLQ formula: a case study of Finland. Regional Studies 2013:47:703-721.

Florida R. Toward the learning region. Futures 1995;27:527-536.

Fokaides PA, Miltiadous IC, Neophytou MKA, Spyridou LP. Promotion of wind energy in isolated energy systems: the case of the Orites wind farm. Clean Technologies and Environmental Policy 2014;16:477-488.

Forschungsstelle für regionale Zeitgeschichte und Public History. Schiffbau - Werftenkrise und Subventionsdschungel - Schleswig-Holsteins Leitindustrie Schiffbau im Strukturwandel, http://www.vimu.info/general_04.jsp?id=mod_28_6\&lang=de\&u=teacher; 2016 [accessed 31 March 2020].

Fouquet R. Long run trends in energy-related external costs. Ecological Economics 2011;70:2380-2389.

Fraunhofer ISE, editor. Current and future cost of photovoltaics Long-term Scenarios for Market Development, System Prices and LCOE of Utility-Scale PV Systems. Freiburg: Fraunhofer ISE; 2015.

Fraunhofer IWES, editor. Windenergie Report Deutschland 2014. Kassel: Fraunhofer IWES; 2015.

Frenken K, Van Oort F, Verburg T. Related variety, unrelated variety and regional economic growth. Regional Studies 2007;41:685-697. 
Gagnon L, Belanger C, Uchiyama Y. Life-cycle assessment of electricity generation options: The status of research in year 2001. Energy Policy 2002;14:1267-1278.

Gailing L, Röhring A. Was ist dezentral an der Energiewende? Infrastrukturen erneuerbarer Energien als Herausforderungen und Chancen für ländliche Räume. Raumforschung und Raumordnung 2015;73:31-43.

GAO, editor. Renewable Energy. Wind Power's Contribution to Electric Power Generation and Impact on Farms and Rural Communities. Washington, DC: United States Government Accountability Office; 2004.

Geels FW. Technological transitions as evolutionary reconfiguration processes: a multi-level perspective and a case-study. Research Policy 2002;31:1257-1274.

Geels FW. From sectoral systems of innovation to socio-technical systems: Insights about dynamics and change from sociology and institutional theory. Research Policy 2004;33:897-920.

Geels FW. Processes and patterns in transitions and system innovations: Refining the coevolutionary multi-level perspective. Technological Forecasting and Social Change 2005;72:681-696.

Geels FW. A socio-technical analysis of low-carbon transitions: introducing the multi-level perspective into transport studies. Journal of Transport Geography 2012;24:471-482.

Geels FW, Kern F, Fuchs G, Hinderer N, Kungl G, Mylan J, Neukirch M, Wassermann, S. The enactment of socio-technical transition pathways: a reformulated typology and a comparative multi-level analysis of the German and UK low-carbon electricity transitions (1990-2014). Research Policy 2016;45:896-913.

Geels FW, Schot J. Typology of sociotechnical transition pathways. Research Policy 2007;36:399-417.

Gerbaulet C, Egerer J, Oei PY, Paeper J, v Hirschhausen C. Die Zukunft der Braunkohle in Deutschland im Rahmen der Energiewende. Berlin: DIW; 2012.

Gesellschaft für Bürgergutachten, editor. Energie und Bürgerbeteiligung, http://www. buergergutachten.com/energie-und-buergerbeteiligung/; 2017 [accessed 08 August 2019].

Gilmartin M, Allan G. Regional employment impacts of marine energy in the Scottish economy. A general equilibrium approach. Regional Studies 2015;49:337-355.

Gils HC, Dotzauer M, Acksel D, Palzer A, Hüsing F, Littwin M, Horst J, Fischedick M, Merten F. Sektorenkopplung als Baustein der Energiewende, https://www.fvee.de/fileadmin/ publikationen/Themenhefte/th2016/th2016_03_02.pdf; 2016 [accessed 31 March 2020]. 
Goldberg M, Sinclair K, Milligan M. Job and Economic Development Impact JEDI Model. A UserFriendly Tool to Calculate Economic Impacts from Wind Projects. Golden, CO: NREL; 2004.

Gosens J, Lu Y, Coenen L. Clean-tech Innovation in Emerging Economies: Transnational Dimensions in Technological Innovation System Formation. Lund: Centre for Innovation, Research and Competence in the Learning Economy; 2013.

Gotchev B. Bundesländer machen Bürgerbeteiligung bei Wind verpflichtend - Teil 1, https:// www.iass-potsdam.de/de/node/5388; 2016 [accessed 08 August 2019].

Graf HJ. Windkraft in der Kritik. Klimaheilmittel und Krankmacher, https://www. deutschlandfunkkultur.de/windkraft-in-der-kritik-klimaheilmittel-und-krankmacher.976. de.html?dram:article_id=416029; 2018 [accessed 08 August 2019].

Grahber G. The weakness of strong ties - the lock-in of regional development in the Ruhr area. In: Grabher G, editor. The Embedded Firm: On the Socioeconomics of Industrial Networks, London: Routledge; 1993, p. 255-277.

Gries L. Versorger in Not - Wird der Hambacher Forst zum Fukushima für RWE? In: Tagesschau 14/11/2018, https://boerse.ard.de/aktien/wird-der-hambacher-forst-zum-fukushima-fuerrwe100.html; 2018 [accessed 08 August 2019].

Gross C. Community perspectives of wind energy in Australia: The application of a justice and community fairness framework to increase social acceptance. Energy Policy 2007;35:2727-2736.

Haines A, McMichael AJ, Smith KR, Roberts I, Woodcock J, Markandya A, Armstrong BG, Campbell-Lendrum D, Dangour AD, Davies M, Bruce N, Tonne C, Barrett M, Wilkinson P. Public health benefits of strategies to reduce greenhouse-gas emissions: overview and implications for policy makers. The Lancet 2009;374:2104-2114.

Hansen T, Coenen L. The geography of sustainability transitions: Review, synthesis and reflections on an emergent research field. Environmental Innovation and Societal Transitions 2015;17:92-109.

Hardin G. The tragedy of the commons. Science 1968;162:1243-1248.

Hau E. Windkraftanlagen: Grundlagen. Technik. Einsatz. Wirtschaftlichkeit. 6 ed. Berlin: SpringerVerlag.; 2017.

Heavner B, Churchill S. Renewables Work - Job Growth from Renewable Energy Development in California. Sacramento, CA: CALPIRG Charitable Trust; 2002. 
Heavner B, Del Chiaro B. Renewable energy and jobs. Employment impacts of developing markets for renewables in California. Sacramento, CA: Environment California Research and Policy Center; 2003.

Heavner B, Pregulman R, Madsen T. Energy for Washingtons Economy - Economic Development from Energy Efficiency and Wind Power in Washington. Seattle, WA:WashPIRG Foundation; 2003.

Hein L, Roberts P, Gonzalez L. Valuing a Statistical Life Year in Relation to Clean Air. Journal of Environmental Assessment Policy and Management 2016;18.

Heindl Server GmbH, editor. SolarServer - Das Internetportal zur Sonnenenergie, https://www. solarserver.de/; s.a. [accessed 29 July 2015].

Henning HM, Palzer A. 100 \% erneuerbare Energien für Strom und Wärme in Deutschland. Freiburg: Fraunhofer-Institut für Solare Energiesysteme ISE; 2012.

Hermann H, Schumacher K, Förster H. Beschäftigungsentwicklung in der Braunkohleindustrie: Status quo und Projektion. Dessau-Roßlau: Umweltbundesamt; 2018.

Hillebrand B, Buttermann HG, Behringer JM, Bleuel M. The expansion of renewable energies and employment effects in Germany. Energy Policy 2006;34:3484-3494.

Hirschl B, Aretz A, Böther T. Wertschöpfung und Beschäftigung durch Erneuerbare Energien in Mecklenburg-Vorpommern 2010 und 2030. Kurzstudie im Auftrag der SPDLandtagsfraktion Mecklenburg-Vorpommern, Schwerin. Berlin: IÖW; 2011.

Hirschl B, Aretz A, Prahl A, Böther T, Heinbach K, Pick D, Funcke S. Kommunale Wertschöpfung durch Erneuerbare Energien. Berlin: IÖW; 2010.

Hirschl B, Heinbach K, Prahl A, Salecki S, Schröder A, Aretz A, Weiß J. Wertschöpfung durch erneuerbare Energien - Ermittlung der Effekte auf Landes- und Bundesebene. Berlin: IÖW; 2015.

Holub HW, Schnabl H. Input-Output-Analyse. München, Wien: Oldenbourg; 1994.

Hopkin M. Climate sceptics switch focus to economics. Nature 2007;445:582-583.

Hopwood B, Mellor M, O'Brien G. Sustainable development: mapping different approaches. Sustainable Development 2005;13:38-52.

Hubik F. Batteriespeicher vor schnellem Durchbruch. In: Handelsblatt 18/09/2015, https://www. handelsblatt.com/technik/zukunftderenergie/neue-billig-akkus-batteriespeicher-vorschnellem-durchbruch/12339380-all.html?ticket=ST-2959071-XGqIVuufky0Alwudofauap4; 2015 [accessed 08 August 2019]. 
Hurley F, Hunt A, Cowie H, Holland M, Miller B, Pye S, Watkiss P. Methodology for the costbenefit analysis for CAFE: Volume 2: health impact assessment. Didcot: AEA Technology Environment; 2005.

IEA, editor. Global $\mathrm{CO}_{2}$ emissions by sector, 2017, https://www.iea.org/data-and-statistics/charts/ global- $\mathrm{CO}_{2}$-emissions-by-sector-2017; 2019 [accessed 31 March 2020].

IEA-RETD, editor. Residential Prosumers - Drivers and Policy Options, http://iea-retd.org/ wp-content/uploads/2014/09/RE-PROSUMERS_IEA-RETD_2014.pdf; 2014 [accessed 08 February 2018].

IHK Aachen, editor. Ja zur Energiewende effizient und mit Augenmaß. Aachen: Industrie- und Handelskammer Aachen; 2014.

IHK Aachen, editor. Netzwerk Energie, https://energie.aachen.ihk.de/sites/fitaa/welcome.aspx; s.a.a [accessed 27/08/2015].

IHK Aachen, editor. IHKs richten „Rheinischen Appell“ an die Kohlekommission. https:// www.aachen.ihk.de/innovation/Energie/energiewende2/rheinischer-appell-ankohlekommission/4231468; s.a.b [accessed 08 August 2019].

IMPLAN, editor. IMPLAN, http://implan.com/; 2015a [accessed 28 December 2015].

IMPLAN, editor. IMPLAN Data Sources, http://www.implan.com/index.php?option=com_content \&view=article\&id=250:250\&catid=222:222\#output-dat; 2015b [accessed 28 December 2015] .

IMPLAN, editor. IMPLAN's Gravity Model and Tradeflow RPCs, www.implan.com/index.php? option=com_content\&view=article\&id=406:406\&catid=223:223; 2015c [accessed 28 December 2015].

Internationales Wirtschaftsforum Regenerative Energien, editor. Solardachbörse, http://www. solardachboerse.de/marktplatz/; s.a. [accessed 29 December 2017].

Interviewee A. Interview with a project developer in the district of Aachen in March 2019 (unpublished).

IPCC, editor. Mitigation of Climate Change. Contribution of Working Group III to the Fifth Assessment Report of the Intergovernmental Panel on Climate Change. Cambridge University Press: Cambridge, United Kingdom and New York, NY, USA; 2014.

IRR, editor. IRR Innovationsregion Rheinisches Revier GmbH. https://www.rheinisches-revier. de/; 2019 [accessed 08 August 2019]. 
Isacs L, Finnveden G, Dahllöf L, Håkansson C, Petersson L, Steen B, Swanström L, Wikström A. Choosing a monetary value of greenhouse gases in assessment tools: A comprehensive review. Journal of Cleaner Production 2016;127:37-48.

Isard W. Methods of regional analysis Cambridge, MA: The MIT Press; 1960.

Isoard S, Soria A. Technical change dynamics: evidence from the emerging renewable energy technologies. Energy Economics 2001;23:619-636.

IT.NRW, editor. Realsteuer-Hebesätze in Nordrhein-Westfalen im Jahr 2014, https://www.it.nrw. de/presse/pressemitteilungen/2015/pdf/180_15.pdf; 2015 [accessed 08 February 2018].

IT.NRW, editor. Realsteuervergleich der Gemeinden in Nordrhein-Westfalen, https://www.landesdatenbank.nrw.de/ldbnrw/online/online;jsessionid=. worker3?sequenz=statistiken\&selectionname=7*; 2017a [accessed 03 March 2018].

IT.NRW, editor. Kommunalprofil: Sozialversicherungspflichtig Beschäftigte am Arbeitsort nach Geschlecht, Nationalität und Wirtschaftszweigen, https://www.it.nrw.de/kommunalprofil/ downloads/index.html; 2017b [accessed 08 February 2018].

IT.NRW, editor. Realsteuervergleich der Gemeinden in Nordrhein-Westfalen, https://www.it.nrw. de/statistik/s/index.html; 2018 [accessed 11 April 2018].

IT.NRW, editor. Landesbetrieb IT.NRW Statistik und Dienstleistungen, https://www.it.nrw/; 2020 [accessed 31 March 2020].

IT.NRW, editor. Gebiet, Bevölkerung, Haushalte, https://www.it.nrw.de/statistik/a/; s.a. [accessed 08 February 2018].

Jacobson MZ. Review of solutions to global warming, air pollution, and energy security. Energy \& Environmental Science 2009;2:148-173.

Jacobsson S, Bergek A. Transforming the energy sector: the evolution of technological systems in renewable energy technology. Industrial and Corporate Change 2004;13:815-849.

Jägemann C, Fürsch M, Hagspiel S, Nagl S. Decarbonizing Europe's power sector by 2050Analyzing the economic implications of alternative decarbonization pathways. Energy Economics 2013;40:622-636.

Jahn M. A spatial CGE Model for the analysis of regional climate change impacts and adaptation policies. Hamburg: HWWI Research; 2014.

Janzing B. Wenn Windräder zu alt werden, http://www.klimaretter.info/energie/ hintergrund/19919-wenn-windraeder-zu-alt-werden; 2015 [accessed 08 February 2018]. 
Jenniches S. Assessing the regional economic impacts of renewable energy sources - A literature review. Renewable and Sustainable Energy Reviews 2018;93:35-51

Jenniches S, Worrell E. Regional economic and environmental impacts of renewable energy developments: Solar PV in the Aachen Region. Energy for Sustainable Development 2019;48:11-24.

Jenniches S, Worrell E, Fumagalli E. Regional economic and environmental impacts of wind power developments: A case study of a German region. Energy Policy 2019;132:499-514.

Jenniches S, Truffer B, Fumagalli E, Worrell E. Energy transitions at the subnational scale: How to get the former German frontrunner region Aachen back on track (submitted to Energy Policy).

Jones C, Bryan J, Munday M, Roberts A. The Input-Output Tables for Wales 2007. Cardiff: Cardiff Business School; 2010.

Juillard É. La région: essai de définition. In Annales de Géographie 1962;71:483-499.

Karl TR, Trenberth, KE. Modern global climate change. Science 2003;302:1719-1723.

Kayden JS. National land-use planning in America: Something whose time has never come. Washington University Journal of Law \& Policy 2000;3:445-472.

Keating M. Rethinking the region: culture, institutions and economic development in Catalonia and Galicia. European Urban and Regional Studies 2001;8:217-234.

Keating M, Loughlin J, Deschouwer K. Culture, Institutions and Economic Development. Cheltenham: Edward Elgar Publishing; 2003.

Kelm T. Marktanalyse Photovoltaik - Schwerpunkt Eigenverbrauch, https://www.erneuerbareenergien.de/EE/Redaktion/DE/Downloads/marktanalyse-pv-workshop-01-vortrag-zsw. pdf?__blob=publicationFile\&v=3; 2015 [accessed 08 February 2018].

Kelm T, Schmidt M, Taumann M, Püttner A, Jachmann H, Capota M. Vorbereitung und Begleitung der Erstellung des Erfahrungsberichts 2014 gemäß $§ 65$ EEG im Auftrag des Bundesministeriums für Wirtschaft und Energie - Vorhaben Ilc Solare Strahlungsenergie. https://www.clearingstelle-eeg-kwkg.de/files/zwischenbericht-vorhaben-2c.pdf; 2014 [accessed 08 February 2018].

Keppler, D. Regionale Einflussfaktoren auf den Ausbau erneuerbarer Energien: Ergebnisse einer Fallstudie in der Brandenburger Energieregion Lausitz. GAIA: ökologische Perspektiven für Wissenschaft und Gesellschaft 2007;4:289-296.

Keppler D. „Das persönliche Engagement derer, die hier sind, das ist doch das eigentlich Wertvolle" - Die Bürgerausstellung als Forum für die Stimmen von BürgerInnen zur Zukunft der Energieregion Lausitz. Berlin: Zentrum Technik und Gesellschaft; 2008. 
Kern F. Using the multi-level perspective on socio-technical transitions to assess innovation policy. Technological Forecasting and Social Change 2012;79:298-310.

KfW, editor. KfW - Bank aus Verantwortung, https://www.kfw.de/kfw.de.html; 2015 [accessed 01 December 2015].

Kildegaard A, Myers-Kuykindall J. Community vs corporate wind. Does it matter who develops the wind in Big Stone County MN? Morris, MN: University of Minnesota; 2006.

Kinzig AP, Kammen DM. National trajectories of carbon emissions: analysis of proposals to foster the transition to low-carbon economies. Global Environmental Change 1998;8:183-208.

Kirkegaard JF, Hanemann T, Weischer L, Miller, M. Toward a sunny future? Global integration in the solar PV industry. Washington, DC: Peterson Institute for International Economics; 2010.

Klobasa M, Sensfuß, F. $\mathrm{CO}_{2}-$ Minderung im Stromsektor durch den Einsatz erneuerbarer Energien im Jahr 2010 und 2011. Karlsruhe: Fraunhofer ISI; 2013.

Klobasa M, Sensfuß F. $\mathrm{CO}_{2}$-Minderung im Stromsektor durch den Einsatz erneuerbarer Energien im Jahr 2012 und 2013. Dessau-Roßlau: Umweltbundesamt, 2016.

Knauß F. So wichtig ist die Braunkohle noch für Deutschland, https://www.wiwo.de/ politik/deutschland/energiewende-so-wichtig-ist-die-braunkohle-noch-fuerdeutschland/22838404.html; 2018 [accessed 31 March 2020].

Koch N, Fuss S, Grosjean G, Edenhofer O. Causes of the EU ETS price drop: Recession, CDM, renewable policies or a bit of everything?-New evidence. Energy Policy 2014;73:676-685.

Kommission Wachstum, Strukturwandel und Beschäftigung, editor. Abschlussbericht, http:// www.spiegel.de/media/media-44069.pdf; 2019 [accessed 08 May 2019].

Kopiske J, Gerhard N. 2030 kohlefrei. Wie eine beschleunigte Energiewende Deutschlands Beitrag zum Pariser Klimaschutzabkommen sicherstellt. Kassel: Fraunhofer-Institut für Energiewirtschaft und Energiesystemtechnik; 2018.

Kost C, Mayer JN, Thomsen J, Hartmann N, Senkpiel C, Philipps S, Nold S, Lude S, Saad N, Schlegl T. Levelized Cost of Electricity Renewable Energy Technologies. Freiburg: Fraunhofer ISE; 2013.

Kost C, Shammugam S, Jülch V, Nguyen HT, Schlegl T. Stromgestehungskosten Erneuerbare Energien. Freiburg: Fraunhofer ISE; 2018.

Krewitt W. External costs of energy-do the answers match the questions? Looking back at 10 years of ExternE. Energy Policy 2002;30:839-848. 
Kronenberg T. Construction of Regional Input-Output Tables Using Nonsurvey Methods - The Role of Cross-Hauling. International Regional Science Review 2009;32:40-64.

Kronenberg T, Többen J, Regional input-output modelling in Germany. The case of North RhineWestphalia, https://mpra.ub.uni-muenchen.de/35494/; 2011 [accessed 29 December 2017].

LAK, editor. Bruttostromerzeugung nach Energieträgern, http://www.lak-energiebilanzen.de/ bruttostromerzeugung-nach-energietraegern/; s.a. [accessed 08 February 2018].

Landesverband der Berg- und Knappenvereine NRW, editor. Landesverbandes der Berg- und Knappenvereine Nordrhein-Westfalen, https://knappen-nrw.de/; 2019 [accessed 08 August 2019].

Landt CC, Kjaer T. Creating space for renewables, https://www.balticenergyareas.eu/images/ achievements/WP2.1_report_final.pdf; s.a. [accessed 31 March 2020].

Lantz E, Tegen S. Economic Benefits, Carbon Dioxide $\mathrm{CO}_{2}$ Emissions Reductions, and Water Conservation Benefits from 1,000 Megawatts MW of New Wind Power in Arizona. Golden, CO: NREL; 2008a.

Lantz E, Tegen S. Economic Benefits, Carbon Dioxide $\mathrm{CO}_{2}$ Emissions Reductions, and Water Conservation Benefits from 1,000 Megawatts MW of New Wind Power in Idaho. Golden, CO: NREL; 2008b.

Lantz E, Tegen S. Economic Benefits, Carbon Dioxide $\mathrm{CO}_{2}$ Emissions Reductions, and Water Conservation Benefits from 1,000 Megawatts MW of New Wind Power in Indiana. Golden, CO: NREL; 2008c.

Lantz E, Tegen S. Economic Benefits, Carbon Dioxide $\mathrm{CO}_{2}$ Emissions Reductions, and Water Conservation Benefits from 1,000 Megawatts MW of New Wind Power in Maine. Golden, CO: NREL; 2008d.

Lantz E, Tegen S. Economic Benefits, Carbon Dioxide $\mathrm{CO}_{2}$ Emissions Reductions, and Water Conservation Benefits from 1,000 Megawatts MW of New Wind Power in Montana. Golden, CO: NREL; 2008e.

Lantz E, Tegen S. Economic Benefits, Carbon Dioxide $\mathrm{CO}_{2}$ Emissions Reductions, and Water Conservation Benefits from 1,000 Megawatts MW of New Wind Power in New Mexico. Golden, CO: NREL; $2008 f$.

Lantz E, Tegen S. Economic Benefits, Carbon Dioxide $\mathrm{CO}_{2}$ Emissions Reductions, and Water Conservation Benefits from 1,000 Megawatts MW of New Wind Power in Nevada. Golden, CO: NREL; 2008g. 
Lantz E, Tegen S. Economic Benefits, Carbon Dioxide $\mathrm{CO}_{2}$ Emissions Reductions, and Water Conservation Benefits from 1,000 Megawatts MW of New Wind Power in Pennsylvania. Golden, CO: NREL; 2008h.

Lantz E, Tegen S. Economic Benefits, Carbon Dioxide $\mathrm{CO}_{2}$ Emissions Reductions, and Water Conservation Benefits from 1,000 Megawatts MW of New Wind Power in South Dakota. Golden, CO: NREL; 2008i.

Lantz E, Tegen S. Economic Benefits, Carbon Dioxide $\mathrm{CO}_{2}$ Emissions Reductions, and Water Conservation Benefits from 1,000 Megawatts MW of New Wind Power in Utah. Golden, CO: NREL; 2008j.

Lantz E, Tegen S. Economic Benefits, Carbon Dioxide $\mathrm{CO}_{2}$ Emissions Reductions, and Water Conservation Benefits from 1,000 Megawatts MW of New Wind Power in West Virginia. Golden, CO: NREL; 2008k.

Lantz E, Tegen S. Economic Benefits, Carbon Dioxide $\mathrm{CO}_{2}$ Emissions Reductions, and Water Conservation Benefits from 1,000 Megawatts MW of New Wind Power in Wisconsin. Golden, CO: NREL; 2008I.

Lantz E. Economic Development Benefits from Wind Power in Nebraska: A Report for the Nebraska Energy Office Golden, CO. NREL; 2009.

Lantz E, Tegen S. Economic Benefits, Carbon Dioxide $\mathrm{CO}_{2}$ Emissions Reductions, and Water Conservation Benefits from 1,000 Megawatts MW of New Wind Power in North Carolina . Golden, CO: NREL; 2009a.

Lantz E, Tegen S. Economic Benefits, Carbon Dioxide $\mathrm{CO}_{2}$ Emissions Reductions, and Water Conservation Benefits from 1,000 Megawatts MW of New Wind Power in Tennessee. Golden, CO: NREL; 2009b.

Lantz E, Tegen S. Economic Benefits, Carbon Dioxide $\mathrm{CO}_{2}$ Emissions Reductions, and Water Conservation Benefits from 1,000 Megawatts MW of New Wind Power in Massachusetts. Golden, CO: NREL; 2009c.

LANUV, editor. Potenzialstudie Erneuerbare Energien in NRW Teil 2 - Solarenergie. Recklinghausen: Landesamt für Natur, Umwelt und Verbraucherschutz NordrheinWestfalen; 2013.

LANUV, editor. Energieatlas Nordrhein-Westfalen - Daten- und Berechnungsgrundlagen, http:// www.energie atlasnrw.de/site/nav2/Allgemeines.aspx?P=1; 2016 [accessed 28 July 2016]. 
Lehr U, Edler D, O'Sullivan M, Peter F, Bickel P. Beschäftigung durch erneuerbare Energien in Deutschland: Ausbau und Betrieb, heute und morgen. Osnabrück, Berlin, Stuttgart: GWS, DIW, Prognos, DLR, ZSW; 2015.

Lehr U, Lutz C, Edler D. Green jobs? Economic impacts of renewable energy in Germany. Energy Policy 2012;47:358-364.

Leipziger Institut für Energie, editor. Kurzexpertise - Wirtschaftlichkeit Energiespeicher. Leipzig: Leipziger Institut für Energie; 2014.

Leipziger Institut für Energie, editor. Marktanalyse - Windenergie an Land, http://www.bmwi. de/Redaktion/DE/Downloads/S-T/studie-windernergie-an-land.html; 2015 [accessed 29 December 2017].

Leontief WW. Quantitative input and output relations in the economic systems of the United States. The Review of Economic Statistics 1936;18:105-125.

Leontief WW. Input-output economics. Scientific American 1951;185:15-21.

Lieblich A, Tuval-Mashiach R, Zilber, T. Narrative research: Reading, analysis, and interpretation (Vol. 47). Thousand Oaks, CA, London, New Delhi, Sage; 1998.

Liesenfeld J, Stachowiak J, Jenniches S. Akteurs- und Institutionenanalyse - Teil 1: Bestandsaufnahme - Erneuerbare Energien, Energieeffizienz und Klimaschutz in der Städteregion Aachen. Duisburg: RISP; 2015.

Liggesmeyer P, Rombach D, Bomarius F. Smart Energy. In: Neugebauer R, editor. Digitalisierung Springer-Verlag: Berlin, Heidelberg; 2018, p. 347-363.

Llera E, Scarpellini S, Aranda A, Zabalza I. Forecasting job creation from renewable energy deployment through a value-chain approach. Renewable and Sustainable Energy Reviews 2013;21:262-271.

Llera-Sastresa EL, Usón AA, Bribián IZ, Scarpellini S. Local impact of renewables on employment: assessment methodology and case study. Renewable and Sustainable Energy Reviews 2010; 14:679-690.

Loomis D, Hinman JL. Economic impact of wind energy development in Illinois. Normal, IL: Illinois State University; 2010.

Loomis D. Economic Impact of the Pleasant Ridge Wind energy Project. Bloomington, IL: Strategic Economic Research; s.a. 
Lorenzoni, I, Nicholson-Cole S, Whitmarsh L. Barriers perceived to engaging with climate change among the UK public and their policy implications. Global Environmental Change 2007;17:445-459.

Louwen A, Sark WGJHM, Schropp REI, Turkenburg WC, Faaij APC. Life-cycle greenhouse gas emissions and energy payback time of current and prospective silicon heterojunction solar cell designs. Progress in Photovoltaics: Research and Applications 2015;23:1406-1428.

Lühr O, Lambert J, Weiß J, Schütz N, Buck M, Schüle K, Klose G, Simpson R, Dörendahl E, Liesenfeld J. Umweltwirtschaftsbericht NRW. Düsseldorf: Ministerium für Umwelt, Landwirtschaft, Natur- und Verbraucherschutz des Landes Nordrhein-Westfalen; 2017.

Luthra S, Kumar S, Garg D, Haleem A. Barriers to renewable/sustainable energy technologies adoption: Indian perspective. Renewable and Sustainable Energy Reviews 2015;41:762-776.

Macron E. There is no Planet B. Retraction in: BBC, editor. Macron to US Congress: 'There is no Planet B', https://www.bbc.com/news/av/world-us-canada-43900009/macron-to-uscongress-there-is-no-planet-b [accessed 17 April 2020].

Madlener R, Koller M. Economic and $\mathrm{CO}_{2}$ mitigation impacts of promoting biomass heating systems: an input-output study for Vorarlberg, Austria. Energy Policy 2007;35:6021-6035.

Madsen T, Bonin S, Baker M. Wind Energy. Powering Economic Development in Colorado. Denver, CO: Colorado Public Interest Research Group Education Fund; 2002.

Markard J, Raven R, Truffer B. Sustainability transitions: An emerging field of research and its prospects. Research Policy 2012;41:955-967.

Maubach KD. Strom 4.0: Innovationen für die deutsche Stromwende. Wiesbaden: SpringerVerlag; 2015.

McCubbin D, Sovacool BK. Quantifying the health and environmental benefits of wind power to natural gas. Energy Policy 2013;53:429-441.

Meagher K. Introduction: Special Issue on 'Informal Institutions and Development in Africa'. Africa Spectrum 2007;42:405-418.

Memmler M, Lauf T, Wolf K, Schneider S. Emissionsbilanz erneuerbarer Energieträger Bestimmung der vermiedenen Verluste im Jahr 2016. Dessau-Roßlau: Umweltbundesamt; 2017.

Memmler M, Schrempf L, Hermann S, Schneider S, Pabst J, Dreher M. Emissionsbilanz erneuerbarer Energieträger - Bestimmung der vermiedenen Verluste im Jahr 2013. DessauRoßlau: Umweltbundesamt; 2014. 
Mertens K. Photovoltaik: Lehrbuch zu Grundlagen, Technologie und Praxis. München: Carl Hanser Verlag; 2015.

Meyer J, Barzantny K, Bonitz J, Gelb A, Werner M. Machbarkeitsstudie: Potentiale Erneuerbarer Energien im Regierungsbezirk Arnsberg. Aachen: Siemens Industry Solutions; 2011.

Meyerhoff J, Ohl C, Hartje V. Landscape externalities from onshore wind power. Energy Policy 2010;38:82-92.

Miernyk WH. The elements of input-output analysis. New York: Random House; 1965.

Miller RE, Blair PD. IO analysis: foundations and extensions. 2nd ed. Cambridge: Cambridge University Press; 2009.

Moosmüller G. Methoden der empirischen Wirtschaftsforschung München: Pearson Studium; 2004.

Moreno B, Lopez AJ. The effect of renewable energy on employment. The case of Asturias Spain. Renewable and Sustainable Energy Reviews 2008;12:732-751.

Morris C, Jungjohann A. Energy democracy: Germany's Energiewende to renewables. Basingstoke: Palgrave Macmillan; 2016.

Müller D. Umweltfachliche Argumente sprechen gegen Windräder: Bürgerinitiative Gegenwind sieht überwiegend negative Effekte: „Anlagen im Wald zerstören die Natur“. In: Aachener Zeitung 09/01/2016, https://www.aachener-zeitung.de/; 2016 [accessed 08 August 2019].

Mulvaney KK, Woodson P, Prokopy LS. A tale of three counties: Understanding wind development in the rural Midwestern United States. Energy Policy 2013;56:322-330.

Munksgaard J, Larsen A. Socio-economic assessment of wind power - lessons from Denmark. Energy Policy 1998;26:85-93.

Murphy JT. Human geography and socio-technical transition studies: Promising intersections. Environmental Innovation and Societal Transitions 2015;17:73-91.

MWIDE NRW, editor. Technologieregion Aachen: Vorzeigemodell für europäische Strukturpolitik in Nordrhein-Westfalen, http://www.ziel2.nrw.de/0_2_Aktuelles/2009_10_27_ Veranstaltungshinweis_Technologieregion_Aachen/index.php; s.a. [accessed 08 August 2019].

NASA, editor. Global Climate Change - Vital Signs of the Planet, https://climate.nasa.gov/; 2017 [accessed 29 December 2017].

NASA, editor. Global Climate Change, https://climate.nasa.gov/effects/; 2019 [accessed 31 March 2020]. 
Nelson RR, Winter SG. An Evolutionary Theory of Economic Change. Belknap Press/Harvard University Press: Cambridge, MA; 1982.

Netztransparenz, editor. EEG-Vergütungs- und Umlagekategorien, https://www.netztransparenz. de/EEG/Verguetungs-und-Umlagekategorien; 2018 [accessed 13 March 2018].

Neumayer E. In defence of historical accountability for greenhouse gas emissions. Ecological economics 2000;33:185-192.

Norddeutscher Rundfunk, editor. Tihange - Nachrichten und Themen, https://www.tagesschau. de/thema/tihange/; 2017 [accessed 08 August 2019].

Nordhaus W. Estimates of the social cost of carbon: concepts and results from the DICE-2013R model and alternative approaches. Journal of the Association of Environmental and Resource Economists 2014;1:273-312.

North DC. Institutions. Journal of Economic Perspectives 1991;5:97-112.

Novan K. Valuing the Wind: Renewable Energy Policies and Air Pollution Avoided. American Economic Journal: Economic Policy 2015;7:291-326.

NREL, editor. About JEDI Models, https://www.nrel.gov/analysis/jedi/about_jedi.html; 2012 [accessed 29 December 2017].

NREL, editor. JEDI: Jobs and Economic Development Impact Models https://www.nrel.gov/ analysis/jedi/; 2015 [accessed 29 December 2017].

Nugent D, Sovacool BK. Assessing the lifecycle greenhouse gas emissions from solar PV and wind energy: A critical meta-survey. Energy Policy 2014;65:229-244.

Oberst CA, Schmitz H, Madlener R. Are Prosumer Households that much different? Evidence from stated residential energy consumption in Germany. 39th IAEE International Conference, Bergen, Norwway, 19.-22. June 2016; 2016.

OECD, editor. Input-Output tables, http://www.oecd.org/trade/input-outputtables.htm; 2017a [accessed 29 December 2017].

OECD, editor. Economic Outlook No 101 - June 2017: GDP deflators, forecast growth, http://stats. oecd.org/Index.aspx?Queryld=61354; 2017b [accessed 08 February 2018].

OECD, editor. Economic Outlook No 102 - November 2017: GDP deflators, forecast growth, http://stats.oecd.org/Index.aspx?Queryld=61354\#; 2018 [accessed 08 February 2018]. 
Oei PY, Kendziorski M, Walk P, Kemfert C, von Hirschhausen CR. Wann Deutschland sein Klimaziel für 2020 tatsächlich erreicht: Forschungsprojekt im Auftrag von Greenpeace e.V. Berlin: DIW Berlin; 2019.

Office for National Statistics, editor. Gross Value added (GVA), https://www.ons.gov.uk/ economy/grossvalueaddedgva; s.a. [accessed 31 March 2020].

Ogilvie M, Rootes C. The impact of local campaigns against wind energy developments. Environmental Politics 2015:24:874-893.

Ohunakin OS, Adaramola MS, Oyewola OM, Fagbenle RO. Solar energy applications and development in Nigeria: drivers and barriers. Renewable and Sustainable Energy Reviews 2014;32:294-301.

Oreskes N. The scientific consensus on climate change. Science 2004;306;1686.

Owen AD. Renewable energy: Externality costs as market barriers. Energy Policy 2006;34:632-642.

Papendieck A. Die Kommunale Energiewende finanzieren - Fördermöglichkeiten nutzen, http:// www.kommunal-erneuerbar.de/fileadmin/content/PDF/2015_06_02_KfW-Dessau.pdf; 2015 [accessed 11 April 2018].

Partridge MD, Rickman DS. Computable general equilibrium CGE modelling for regional economic development analysis. Regional Studies 2010;44:1311-1328.

Pastakia A. Grassroots ecopreneurs: change agents for a sustainable society. Journal of Organizational Change Management 1998;11:157-173.

Perez-Arriaga IJ, Batlle C. Impacts of intermittent renewables on electricity generation system operation. Economics of Energy \& Environmental Policy 2012;2:3-18.

Peters GP. Policy Update: Managing carbon leakage. Carbon Management 2010;1:35-37.

Preiss P, Roos J, Friedrich R. Estimating Health Risks caused by Emissions of Air Pollutants from Coal Fired Power Plants in Europe. Stuttgart: Institute for Energy Economics and the Rational Use of Energy; 2013.

Presse- und Informationsamt der Bundesregierung, editor. Energiewende - Fragen und Antworten, https://www.bundesregierung.de/Webs/Breg/DE/Themen/Energiewende/FragenAntworten/8_Kernkraft/_node.html;jsessionid=57C163FD23634A440825B548CD98C8DF. s7t1\#doc605176bodyText1; 2018 [accessed 08 August 2019].

Presse- und Informationsamt der Bundesregierung, editor. Was tut die Bundesregierung für den Klimaschutz? https://www.bundesregierung.de/breg-de/themen/klimaschutz/ bundesregierung-klimapolitik-1637146; 2019 [accessed 31 March 2020]. 
Quitzow R. Dynamics of a policy-driven market: The co-evolution of technological innovation systems for solar photovoltaics in China and Germany. Environmental Innovation and Societal Transitions 2015;17:126-148.

Quitzow R, Roehrkasten S, Jaenicke M. The German Energy Transition in International Perspective. Potsdam: Institute for Advanced Sustainability Studies; 2016.

Raadal HL, Gagnon L, Modahl IS, Hanssen OJ. Life cycle greenhouse gas (GHG) emissions from the generation of wind and hydro power. Renewable and Sustainable Energy Reviews 2011;15:3417-3422.

Ratliff DJ, Hartman CL, Stafford ER. An analysis of state-level economic impacts from the development of wind power plants in San Juan County, Utah. Logan, UT: Utah State University; 2010.

Raven R, Schot J, Berkhout F. Space and scale in socio-technical transitions. Environmental Innovation and Societal Transitions 2012;4:63-78.

Raven R, van den Bosch S, Weterings R. Transitions and strategic niche management: towards a competence kit for practitioners. International Journal of Technology Management 2010;51:57-74.

rbb, editor. Protest gegen Umweltministerin - Kohle-Kumpel wenden Schulze den Rücken zu, https://www.rbb24.de/panorama/beitrag/2019/07/protest-kohlekraftwerk-schulze-lausitzbrandenburg.html; 2019 [accessed 31 March 2020].

Reategui S, Hendrickson S. Economic development impact of 1,000 MW of wind energy in Texas. Golden, CO: NREL; 2011.

Reategui S, Tegen S. Economic development impacts of Colorado's first 1000 megawatts of wind energy. Golden, CO: NREL; 2008.

Rebitzer G, Ekvall T, Frischknecht R, Hunkeler D, Norris G, Rydberg T, Schmidt WP, Suh S, Weidema BP, Pennington DW. Life cycle assessment: Part 1: Framework, goal and scope definition, inventory analysis, and applications. Environment International 2004;30:701-720.

Region Aachen Zweckverband, editor. Region Aachen, https://regionaachen.de/ueber-uns. html; s.a. [accessed 08 August 2019]. 
Reichmuth M, Erfurt I, Lorenz C, Schiffler C, Kelm T, Schmidt M, Schott B, Braun M, Büdenbender K, Barth H, Strauß P,Günnewig D, Püschel M, de Beer H, Gehrke M, Puhe H. Vorbereitung und Begleitung der Erstellung des Erfahrungsberichts 2011 gemäß $§ 65$ EEG im Auftrag des Bundesministeriums für Umwelt, Naturschutz und Reaktorsicherheit - Vorhaben Ilc Solare Strahlungsenergie, http://www.ie-leipzig.com/010-dateien/referenzen/pdf/vorbereitung_ und_begleitung_bei_der_erstellung_eines_erfahrungsberichtes.pdf; 2011 [accessed 08 February 2018].

Reinsberger K, Posch A. Dezentrale Energieversorgung-Die Rolle der Photovoltaik in der Energietransition. In: Egger R, Posch A, editors. Lebensentwürfe im ländlichen Raum. Wiesbaden: Springer VS; 2016. p. 187-202.

Remais JV, Hess JJ, Ebi KL, Markandya A, Balbus JM, Wilkinson P, Haines A, Chalabi Z. Estimating the health effects of greenhouse gas mitigation strategies: addressing parametric, model, and valuation challenges. Environmental Health Perspectives 2014;122:447-455.

REMI, editor. What does REMI say? http.//ledsgporg/wp-content/uploads/2015/10/REMIBrochurepdf; s.a. [accessed 29 December 2017].

REN21, editor. Renewables 2018 Global Status Report. Paris: REN21 Secretariat; 2018.

render, editor. Projektinterner Datenbestand der Erneuerbaren Energien Anlagen in der Städteregion Aachen (unpublished); 2016.

render, editor. Regionaler Energieplan Aachen 2030 - Gemeinsam zur EnergieRegion. Aachen: FiW; 2018.

Richardson HW. Input-output and regional economics. London: Weidenfeld and Nicolson; 1972.

Rickards L, Wiseman, J, Kashima, Y. Barriers to effective climate change mitigation: the case of senior government and business decision makers. Wiley Interdisciplinary Reviews: Climate Change 2014;5:753-773.

Rip A, Kemp R. Technological change. In: Rayner S, Malone EL. Human choice and climate change. Vol. II, Resources and Technology Columbus (OH, USA): Battelle Press; 1998. p. 327-399.

RISP, editor. Ergebnisse der Bevölkerungsbefragung 2017 zum Ausbau erneuerbarer Energien in der Städteregion Aachen, https://www.fiw.rwth-aachen.de/neo/fileadmin/pdf/ render/2017_Ergebnisse_zweite_Befragung_render.pdf; 2017 [accessed 08 August 2019].

Roth IF, Ambs LL. Incorporating externalities into a full cost approach to electric power generation life-cycle costing. Energy 2004;29:2125-2144. 
Rubner J. Die Sonnenenergie bestimmt sein Leben. In: Aachener Zeitung 12/03/2005, http:// www.sfv.de/lokal/mails/phj/zehnjaam.htm; 2005 [accessed 08 August 2019].

Ruppert-Winkel C, Hauber J, Aretz A, Funcke S, Kress M, Noz S, Salecki S, Schlager P, Stablo, J. Die Energiewende gemeinsam vor Ort gestalten. Freiburg, Berlin, Stuttgart: Zentrum für Erneuerbare Energien (ZEE), IÖW, Universität Hohenheim; 2013.

RWE Power AG, editor. Strom aus dem Westen - Der Tagebau Inden und das Kraftwerk Weisweiler, http://www.indeland.de/assets/userfiles/img/locations/kraftwerk-weisweiler/ kraftwerk-weisweiler-infobroschuere.pdf; 2009 [accessed 08 February 2018].

RWE Power AG, editor. Die Rolle der Braunkohle, http://www.rwe.com/web/cms/de/76904/ rwe-power-ag/energietraeger/braunkohle/; s.a. [accessed 17 January 2017].

Schlesinger M, Hofer P, Kemmler A, Kirchner A, Koziel S, Ley A, Piégsa A, Seefeldt F, Straßburg S, Weinert K, Lindenberger D, Knaut A, Malischek R, Nick S, Panke S, Paulus S, Tode C,Wagner J Lutz C, Lehr U, Ulrich P. Entwicklung der Energiemärkte-Energiereferenzprognose. Projekt Nr. 57/12 Studie im Auftrag des Bundesministeriums für Wirtschaft und Technologie. Basel, Köln, Osnabrück: Prognos, EWI, GWS; 2014.

Schleswig-Holsteinischer Landtag, editor. Bericht der Landesregierung - Energiewende und Klimaschutz in Schleswig-Holstein - Ziele, Maßnahmen und Monitoring 2015, https://www. landtag.Itsh.de/infothek/wahl18/drucks/3000/drucksache-18-3074.pdf, 2015 [accessed 29 December 2017].

Schmidt TS, Schneider M, Hoffmann VH. Decarbonising the power sector via technological change-differing contributions from heterogeneous firms. Energy Policy 2012;43:466-479.

Schmidt-Mattern B. Arbeitsplätze vs. Klimaschutz, https://www.deutschlandfunk.de/ kohlekommission-arbeitsplaetze-vs-klimaschutz.1773.de.html?dram:article_id=433971; 2018 [accessed 06 December 2018].

Schormann P, Behrla B, editors. Solaranlagen Portal, http://www.solaranlagen-portal.com/; s.a. [accessed 08 February 2018].

Schot J, Hoogma R, Elzen B. Strategies for shifting technological systems: the case of the automobile system. Futures 1994;26:1060-1076.

Schröder A, Kunz F, Meiss J, Mendelevitch R, von Hirschhausen C. Current and prospective costs of electricity generation until 2050. Berlin: DIW; 2013.

SEED Coalition and Public Citizen's Texas office, editors. Renewable Resources: The New Texas Energy Powerhouse. Austin, TX: SEED Coalition and Public Citizen's Texas office; 2002. 
Sevilgen SH, Erdem HH, Cetin B, Akkaya AV, Dağdaş A. Effect of economic parameters on power generation expansion planning. Energy Conversion and Management 2005;46:1780-1789.

Shah VP, Debella DC, Ries RJ. Life cycle assessment of residential heating and cooling systems in four regions in the United States. Energy and Buildings 2008;40:503-513.

Shaker RR, Zubalsky SL. Examining patterns of sustainability across Europe: a multivariate and spatial assessment of 25 composite indices. International Journal of Sustainable Development \& World Ecology 2015; 22:1-13.

Sherwani AF, Usmani JA. Life cycle assessment of solar PV based electricity generation systems: A review. Renewable and Sustainable Energy Reviews 2010;14:540-544.

Siegel J. Diskussion um Kohle-Ausstieg: Warum die Ost-Regierungschefs 60 Milliarden Euro fordern, https://www.Ir-online.de/nachrichten/wirtschaft/diskussion-um-kohle-ausstiegwarum-die-ost-regierungschefs-60-milliarden-euro-fordern-38049152.html; 2018 [accessed 31 March 2020].

Silva E, Acheampong R. Developing an Inventory and Typology of Land-Use Planning Systems and Policy Instruments in OECD Countries. Paris: OECD Publishing; 2015.

Simons G, Peterson T. California renewable technology market and benefits assessment. Palo Alto, CA, Sacramento, CA: Electric Power Research Institute (EPRI), California Energy Commission (CEC); 2001.

Sims REH, Rogner HH, Gregory K. Carbon emission and mitigation cost comparisons between fossil fuel, nuclear and renewable energy resources for electricity generation. Energy Policy 2003;31:1315-1326.

Singh V, Fehrs JE. The work that goes into renewable energy. Washington, DC: Renewable Energy Policy Project; 2001.

Slattery MC, Lantz E, Johnson BL. State and local economic impacts from wind energy projects: Texas case study. Energy Policy 2011;39:7930-7940.

SMA, editor. Gewerblicher Eigenverbrauch von Solarstrom, https://www.sma.de/partner/ expertenwissen/gewerblicher-eigenverbrauch-von-solarstrom.html; 2013 [accessed 08 February 2018].

Smith A, Voß JP, Grin J. Innovation studies and sustainability transitions: The allure of the multilevel perspective and its challenges. Research Policy 2010;39:435-448. 
Solarenergieförderverein e.V., Wind e.V., Greenpeace Gruppe Aachen, editors. Aachen hat Energie - Das Aachener Modell der kostendeckenden Einspeisevergütung, http://www. aachen-hat-energie.de/entw/kv.htm; s.a. [accessed 11 April 2018].

Solomon S, Plattner GK, Knutti R, Friedlingstein, P. Irreversible climate change due to carbon dioxide emissions. Proceedings of the National Academy of Sciences 2009;6:1704-1709.

Spektrum, editor. Lexikon der Geographie: Region. Spektrum: Heidelberg; 2001

Stachowiak J. Regional Governance - Erneuerbare Energien und Energieeffizienz in der Städteregion Aachen - Teil 2: Akteurs- und Institutionenanalyse. Duisburg: RISP; 2016.

Städteregion Aachen, editor. Integriertes Klimaschutzkonzept für die Städteregion Aachen, https://www.staedteregion-aachen.de/fileadmin/user_upload/A_70/A70.5_ Klimaschutz/70.5_Dateien/Kommunale_Klimaschutzkonzepte/Klimaschutzkonzept_der_ StaedteRegion_Aachen.pdf ; 2011 [accessed 08 August 2019].

Städteregion Aachen, editor. Klimaschutzteilkonzept für die Städteregion Aachen - Potenziale der Erneuerbaren Energien, http://enerko.de/wp-content/uploads/2015/06/ErneuerbareEnergien-Konzept-SR.pdf; 2015 [accessed 08 August 2019].

Städteregion Aachen, editor. Tihange abschalten! https://www.staedteregion-aachen.de/de/ navigation/staedteregion/tihange-abschalten/s.a.a [accessed 08 August 2019].

Städteregion Aachen, editor. StädteRegion Aachen, https://www.staedteregion-aachen.de/ de/navigation/staedteregion/; s.a.b [accessed 08 August 2019].

Statistisches Bundesamt, editor. Input-Output Rechnung im Überblick. Wiesbaden: Statistisches Bundesamt; 2010.

Statistisches Bundesamt, editor. Volkswirtschaftliche Gesamtrechnungen - InputOutput Rechnung. s.I.: Statistisches Bundesamt (=Fachserie 18 Reihe 2), https://www. destatis.de/DE/Publikationen/Thematisch/VolkswirtschaftlicheGesamtrechnungen/ InputOutputRechnung/VGRInputOutputRechnung2180200137004.pdf?_blob=publicationFile; 2017 [accessed 11 April 2018].

Stawag, editor. Regionaler Dialog Energiewende (render), Gemeinsam auf dem Weg machen zur EnergieRegion Aachen 2030` Teilprojekt 10 (TP 10): Richtericher Dell. Aachen: Stawag; 2017.

Steer L, Sen K. Formal and informal institutions in a transition economy: The case of Vietnam. World Development 2010;38:1603-1615.

Steinhäußer R, Siebert R, Steinführer A, Hellmich M. National and regional land-use conflicts in Germany from the perspective of stakeholders. Land Use Policy 2015;49:183-194. 
Sterner M, Breuer C, Drees T, Eckert F, Maaz A, Pape C, Rotering N, Thema, M. Speicherbedarf in der Stromversorgung. In: Sterner M, Stadler I, editors. Energiespeicher - Bedarf, Technologien, Integration. Springer-Verlag: Berlin, Heidelberg; 2017, p. 53-140.

Sterner M, Eckert F, Thema M, Bauer F. Der positive Beitrag dezentraler Batteriespeicher für eine stabile Stromversorgung - Kurzstudie im Auftrag von BEE e.V. und Hannover Messe. Forschungsstelle Energienetze und Energiespeicher (FENES), OTH Regensburg: Regensburg, Berlin, Hannover; 2015.

Sterzinger. Component Manufacturing: Indianas Future in the Renewable Energy Industry https://www.hecweb.org/wpcontent/uploads/2010/04/Component_Manufacturing_ Long_Report.pdf; 2008 [accessed 29 December 2017].

Stix E. Leitbilder der Raumordnung in Österreich - Ein beispielhafter Prozess? https://www. arl-net.de/system/files/stix.pdf; 2014 [accessed 08 February 2018].

Stoddard LE, Abiecunas J, O'Connell R. Economic, energy, and environmental benefits of concentrating solar power in California. Golden, CO: NREL; 2006.

Stüer B, Buchsteiner D. Stuttgart 21: Eine Lehre für die Planfeststellung, http://www.stueer. business.t-online.de/aufsatzc/upr0811.pdf; s.a. [accessed 08 August 2019].

Sundqvist T. What causes the disparity of electricity externality estimates? Energy Policy 2004;32:1753-1766.

Suzuki D. Citation. Retraction in: Mudge K, Gabriel S. Farming the woods: an integrated permaculture approach to growing food and medicinals in temperate forests. White River Junction, VT: Chelsea Green Publishing; 2014.

Tanzi V. Globalization, tax competition and the future of tax systems. Washington, DC, Cambridge, MA. International Monetary Fund (IMF), National Bureau of Economic Research (NBER); 1996.

Taunus Zeitung, editor. Weniger Förderung: Lohnt sich die Solaranlage noch? In. Taunus Zeitung 05/03/2012, http://www.taunus-zeitung.de/ratgeber/hausundgarten/Weniger-FoerderungLohnt-sich-die-Solaranlage-noch;art780,391100; 2012 [accessed 31 March 2017].

Tegen S. Comparing statewide economic impacts of new generation from wind, coal, and natural gas in Arizona, Colorado, and Michigan. Golden, CO: NREL; 2006.

Tenta S. Arbeitsplätze in der Braunkohle-Industrie: Wie viele Jobs sind wirklich in NRW gefährdet? https://www1.wdr.de/archiv/braunkohle/arbeitsplaetze-braunkohle-100.html; 2015 [accessed 31 March 2020]. 
The American Solar Energy Society, editor. Defining Estimating and Forecasting the Renewable Energy and Energy Efficiency Industries in the US and in Colorado. Boulder, CO: The American Solar Energy Society; 2008.

Timilsina GR, van Kooten GC, Narbel PA. Global wind power development: Economics and policies. Energy Policy 2013;61:642-652.

Timmons D, Damery D, Allen G, Petraglia L. Energy from forest biomass. Potential economic impacts in Massachusetts, http://www.mass.gov/eea/docs/doer/renewables/biomass/bioeco-impact-biomass.pdf; 2007 [accessed 29 December 2017].

Tol RS. Targets for global climate policy. An overview Journal of Economic Dynamics and Control 2013;37: 911-928.

Tol RS. The Social Cost of Carbon. In: Bernard L, Semmler W. editors. The Oxford Handbook of the Macroeconomics of Global Warming. New York: Oxford University Press; 2015, p. 297-318.

Torgerson M, Sorte B, Nam T. Umatilla County's economic structure and the economic impacts of wind energy development. An Input-Output Analysis. Corvallis, OR: Oregon State University, Extension Service; 2006.

Tourkolias C, Mirasgedis S, Damigos D, Diakoulaki D. Employment benefits of electricity generation: A comparative assessment of lignite and natural gas power plants in Greece. Energy Policy 2009;37: 4155-4166.

Tremeac B, Meunier F. Life cycle analysis of 4.5 MW and 250W wind turbines. Renewable and Sustainable Energy Reviews 2009;13:2104-2110.

Trink T, Schmid C, Schinko T, Steininger KW, Loibnegger T, Kettner C, Pack A, Töglhofer C. Regional economic impacts of biomass based energy service use: A comparison across crops and technologies for East Styria, Austria. Energy Policy 2010;38:5912-5926.

Truffer B, Coenen L. Environmental innovation and sustainability transitions in regional studies. Regional Studies 2012;46:1-21.

Truffer B, Murphy JT, Raven R. (2015). The geography of sustainability transitions: Contours of an emerging theme. Environmental Innovation and Societal Transitions 2015;17:63-72.

Türck-Hövener FJ. Situation der Windenergie in der Städteregion Aachen (several telephone interviews with a wind power developer in the Städteregion Aachen conducted in October and November 2016); 2016. 
Turconi R, Boldrin A, Astrup T. Life cycle assessment (LCA) of electricity generation technologies: Overview, comparability and limitations. Renewable and Sustainable Energy Reviews 2013;28:555-565.

Ulrich P, Distelkamp M, Lehr U, Bickel P, Püttner A. Erneuerbar beschäftigt in den Bundesländern! Bericht zur daten- und modellgestützten Abschätzung der aktuellen Bruttobeschäftigung in den Bundesländern. Osnabrück, Stuttgart: ZSW, GWS; 2012.

Ulrich P, Lehr U. Erneuerbar beschäftigt in den Bundesländern. Bericht zur aktualisierten Abschätzung der Bruttobeschäftigung 2013 in den Bundesländern. http://www.gws-os.com/ discussionpapers/EE_besch\%C3\%A4ftigt_bl_2013.pdf; 2014 [accessed 29 December 2017].

Ulrich P, Lehr U. Erneuerbar beschäftigt in den Bundesländern: Bericht zur aktualisierten Abschätzung der Bruttobeschäftigung 2016 in den Bundesländern. Osnabrück: GWS; 2018.

Umweltbundesamt, editor. Kyoto-Protokoll, https://www.umweltbundesamt.de/themen/klimaenergie/internationale-eu-klimapolitik/kyoto-protokoll; 2013

Umweltbundesamt, editor. Erneuerbare Energien in Deutschland: Daten zur Entwicklung im Jahr 2018. Dessau-Roßlau: Umweltbundesamt; 2019a.

Umweltbundesamt, editor. Stromerzeugung erneuerbar und konventionell, https:// www.umweltbundesamt.de/daten/energie/stromerzeugung-erneuerbarkonventionell\#textpart-4; 2019b [accessed 31 March 2020].

Umweltbundesamt, editor. Indicator: Greenhouse gas emissions, https://www. umweltbundesamt.de/en/indicator-greenhouse-gas-emissions\#textpart-1; 2019c [accessed 08 August 2019].

UNDP, editor. Goal 7 targets, https://www.undp.org/content/undp/en/home/sustainabledevelopment-goals/goal-7-affordable-and-clean-energy/targets/; 2019 [accessed 31 March 2020].

UNEP, editor. Emissions Gap Report 2019. Nairobi: United Nations Environment Programme; 2019.

UFCCC, editor. Kyoto Protocol, http://unfccc.int/kyoto_protocol/items/2830.php; 2014 [accessed 11 April 2018].

UNFCC, editor. The Paris Agreement, https://unfccc.int/process-and-meetings/the-parisagreement/the-paris-agreement; 2020 [accessed 31 March 2020].

United Nations, editor. Renewable energy 'limitless and will last forever,' says Ban at global debate, http://www.un.org/sustainabledevelopment/blog/2016/01/renewable-energy-limitless-andwill-last-forever-says-ban-at-global-debate/; 2016 [accessed 29 December 2017].

Unruh GC. Understanding carbon lock-in. Energy Policy 2000;28:817-830. 
van den Bergh JC, Botzen WJ. A lower bound to the social cost of $\mathrm{CO}_{2}$ emissions. Nature Climate Change 2014:253-258.

Verbong G, Geels F. The ongoing energy transition: lessons from a socio-technical, multi-level analysis of the Dutch electricity system (1960-2004). Energy Policy 2007;35:1025-1037.

von Bost M, Hirschl B, Aretz A. Effekte von Eigenverbrauch und Netzparität bei der Photovoltaik. Berlin, Hamburg: IÖW, Greenpeace Energy eG; 2011.

von Fabeck. Historisches zur kostendeckenden Vergütung bis zu ihrer Aufnahme in das EEG vom 1. Aug. 2004 mit Folien zum Aachener Modell, http://www.sfv.de/lokal/mails/wvf/ kostendeckende_Verguetung_bis_hin_zum_EEG_2004.htm; 2014 [accessed 08 August 2019].

Voß JP, Smith A, Grin J. Designing long-term policy: rethinking transition management. Policy Sciences 2009;42:275-302.

Wagner HJ, Koch MK, Burkhardt J, Bockmann TG, Feck N, Kruse, P. $\mathrm{CO}_{2}$-Emissionen der Stromerzeugung - Ein ganzheitlicher Vergleich verschiedener Techniken. BWK - Das Energie Fachmagazin 2007;59:44-52.

Walker G. Energy, land use and renewables: a changing agenda. Land Use Policy 1995;12:3-6.

Walker G, Cass N. Carbon reduction, 'the public' and renewable energy: engaging with sociotechnical configurations. Area 2007;39:458-469.

Warren CR, Lumsden C, O'Dowd S, Birnie RV. 'Green on green': public perceptions of wind power in Scotland and Ireland. Journal of Environmental Planning and Management 2005;48:853-875.

Watkiss P, Anthoff D, Downing T, Hepburn C, Hope C, Hunt A, Tol R. The Social Costs of Carbon (SCC) Review - Methodological Approaches for Using SCC Estimates in Policy Assessment. London: Department for Environment, Food and Rural Affairs; 2006.

Wei M, Patadia S, Kammen DM. Putting renewables and energy efficiency to work. How many jobs can the clean energy industry generate in the US? Energy Policy 2010;38:919-931.

Wei YM, Wang L, Liao H, Wang K, Murty T, Yan J. Responsibility accounting in carbon allocation: a global perspective. Applied Energy 2014;130:122-133.

Weigel P, Fischedick M. Rolle der Digitalisierung in der soziotechnischen Transformation des Energiesystems. Energiewirtschaftliche Tagesfragen 2018;68:10-16.

Weisbrod G, Polenske KR, Lynch T, Lin X. The Long-Term Economic Impact of Energy Efficiency and Renewable Energy Programs for lowa, http://www.edrgroup.com/library/energyenvironment/iowa-energy.html; 1995 [accessed 29 December 2017]. 
Weiß J, Prahl A, Heinbach K, Hirschl B, Weber G, Salecki S. Kommunale Wertschöpfung durch Erneuerbare Energien in zwei Modellkommunen in Nordrhein-Westfalen. Berlin: IÖW; 2012.

Weisser D. A guide to life-cycle greenhouse gas (GHG) emissions from electric supply technologies. Energy 2007;32:1543-1559.

WHO, editor. 7 million premature deaths annually linked to air pollution. http://www.who.int/ mediacentre/news/releases/2014/air-pollution/en/; 2014 [accessed 11 April 2018].

WHO, editor. Economic cost of the health impact of air pollution in Europe: Clean air, health and wealth. Copenhagen: WHO Regional Office for Europe; 2015.

WHO, editor. Ambient (outdoor) air quality and health. https://www.who.int/en/news-room/ fact-sheets/detail/ambient-(outdoor)-air-quality-and-health; 2018 [accessed 07 April 2019].

Willeke GP, Räuber A. On the history of Terrestrial PV Development: With a Focus on Germany. In: Willecke GP, Weber ER, editors. Advances in Photovoltaics, San Diego, CA, Waltham, MA, Oxford, London, Amsterdam. Academic Press; 2012, p. 7-48.

Wirth H. Aktuelle Fakten zur Photovoltaik in Deutschland, http://www.heliosgmbh.de/app/ download/5793641699/Fraunhofer+ISE+Aktuelle+Fakten+zur+PV.pdf; 2014 [accessed 29 December 2017].

Wirth H. Recent Facts about Photovoltaics in Germany, https://www.ise.fraunhofer.de/ content/dam/ise/en/documents/publications/studies/recent-facts-about-photovoltaics-ingermany.pdf; 2017 [accessed 31 March 2017].

Wirth S, Markard J, Truffer B, Rohracher H. Informal institutions matter: Professional culture and the development of biogas technology. Environmental Innovation and Societal Transitions 2013;8:20-41.

Wolsink M. Wind power implementation: the nature of public attitudes: equity and fairness instead of 'backyard motives'. Renewable and Sustainable Energy Reviews 2007;11:1188-1207.

Wüstenhagen R, Wolsink M, Bürer MJ. Social acceptance of renewable energy innovation: An introduction to the concept. Energy Policy 2007;35:2683-2691.

Yuan X, Zuo J, Huisingh D. Social acceptance of wind power: a case study of Shandong Province, China. Journal of Cleaner Production 2015;92:168-178.

ZSW, editor. Erste Abschätzung ausgewählter ökonomischer Wirkungen der Umsetzung des Energieszenarios Baden-Württemberg 2050. Stuttgart: ZSW; 2012. 
References 


\section{Acknowledgements}

Every journey starts with the first step. After finishing my studies of economic geography, I realised that I had always wanted to work not only to gain practical knowledge but also to continue to develop my scientific skills and expertise. I am very glad that Ernst Worrell gave me the opportunity to pursue both of these, as he accepted me as an external PhD student in the summer of 2015, and I want to thank him for his trust and all the efforts he made to supervise an external PhD project. Dank je wel Ernst; I learned a lot from you. Thanks also to my co-promoter Elena Fumagalli for thoroughly analysing my drafts and for always giving me valuable suggestions that helped me so much in improving my scientific writing skills. Grazie Elena. While I was working at RISP where I was involved in economic development and policy analysis, I learned a lot about cleantech, regional energy transitions, policy design and implementation, for which I am extremely grateful. Special thanks go to Joachim Liesenfeld, leader of the research group Social Change and Innovation. With our fruitful discussions on practical policy design and his generosity in devoting time to me for my research, he truly supported me during this project. My work at N.U.R.E.C. gave me the opportunity to develop my expertise further with regard to economic development in an international context. My sincere thanks go to Robert Tonks for bringing the paper on Regional economic and environmental impacts of wind power developments into proper British English. My job at the Economic Development Agency (WFG) Krefeld gave me the opportunity to transfer my theoretical knowledge into practical implementation. I am very grateful to the WFG Krefeld for giving me the trust and opportunities to apply scientific concepts in the field of economic development, transition and innovation management within a practical context. I am also grateful that the WFG Krefeld undertook the editing costs of the Energy transitions at the subnational scale paper. My work also gave me the opportunity to collaborate with Vincent Pijnenburg, lector of Cross-border Business Development at Fontys Venlo University of Applied Sciences, who proofread my Dutch translation of the summary. Dank je wel Vincent.

In addition to my work colleagues, my family and friends gave me the greatest support in pursuing my endeavour. Writing a dissertation while working full-time is never easy, and I am very grateful for your support, valuable discussions and ongoing motivation. First of all, I would like to thank my parents, Norbert and Irene, for always supporting me in my studies, for strongly believing in me and for teaching me that hard work pays off. Thank you also, Adina, for continuously supporting me in the final stage of my thesis, with your inspiring, warm, and motivating words and your comprehension. Moreover, thank you to my godchildren, Mathias and Lea, and my nephews, Finn and Felix, for reminding me that there is a life other than work and studying. 
My friends were always there for me and cheered me up, especially the GWV (Geographical Hiking Association)-Philipp, Felix, Jan and Björn- which accompanied me since the first semester in Aachen. Thank you in advance, Jan and Björn, for being my paranymphs and standing beside me at my dissertation ceremony. Furthermore, a special thank-you goes to Ellen for proofreading my papers in a very professional manner. Thanks to everyone who accompanied me on this journey and for your strong support during this endeavour. Without you, it would have been a much longer and more difficult way to go. 


\section{About the Author}

Simon Jenniches was born on 24 September 1987, in Prüm (Germany). He obtained his Bachelor of Science in Applied Geography at RWTH Aachen University (Germany) in 2011, with a specialisation in economics and urban planning in 2011. His bachelor thesis, which he wrote in collaboration with the Service Science Factory (SSF) at Maastricht School of Business and Economics, addressed quality assessment instruments for business parks. In his studies for his Master of Science in Economic Geography at RWTH Aachen

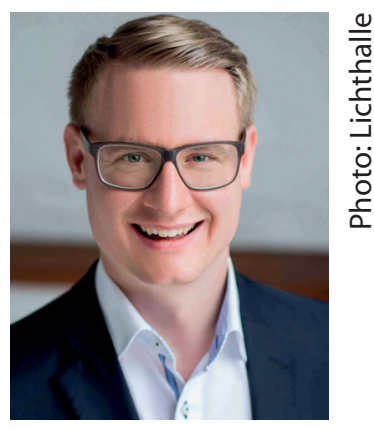
University (Germany) and Université de Lorraine (France), Mr Jenniches focused on economics and regional development. After an internship at the German Development Institute (DIE) in Bonn, he wrote his master thesis about the implementation of energy efficiency in small and medium-sized enterprises in emerging economies, in collaboration with the Fraunhofer Institute for Systems and Innovation (ISI) and the Public Authority for Electricity and Water (PAEW) in Muscat (Oman) and graduated in 2014. In 2015, Mr Jenniches started working as a researcher and consultant at the Rhine-Ruhr Institute for Social Research and Policy Consulting (RISP) at the University of Duisburg-Essen, in the research group Social Change and Innovation. At RISP, he supervised the render (regional dialogue energy transition) project, funded by the German Ministry of Education and Research. In the same year, he started his PhD studies at Utrecht University as an external PhD. His work at RISP gave him the opportunity to study the impacts of energy transitions on a regional scale as well as to acquire practical insights in policy design and transition management, which he applied in his PhD studies. From 2018 to early 2019, he worked as a project manager at the Network on Urban Research in the European Union (N.U.R.E.C.)-Institute Duisburg on a project about German-Dutch cross-border cooperation. Since 2019, Mr Jenniches has worked at the Economic Development Agency Krefeld (Germany) as international project manager, focusing on economic development, foreign direct investment (FDI), and innovation management. His research and working interests lie in economic development, economic transition, innovation, and policy design.

\section{Journal Publications}

Meessen S, Trienes M, Jenniches S. "Convenience“ auf dem Dorf? Standort Zeitschrift für Angewandte Geographie 2012;36:177-186.

Jenniches, S. Assessing the regional economic impacts of renewable energy sources - A literature review. Renewable and Sustainable Energy Reviews 2018;93:35-51. 
Jenniches S, Worrell, E. Regional economic and environmental impacts of renewable energy developments: Solar PV in the Aachen Region. Energy for sustainable development 2019;48:11-24.

Jenniches S, Worrell E, Fumagalli E. Regional economic and environmental impacts of wind power developments: A case study of a German region. Energy Policy 2019;132:499-514.

\section{Further Publications}

Liesenfeld J, Stachowiak J, Jenniches S. Akteurs- und Institutionenanalyse Teil 1: Bestandsaufnahme Erneuerbare Energien, Energieeffizienz und Klimaschutz in der Städteregion Aachen. Duisburg: RISP; 2015.

Jenniches S, Schneider J. Potenziale und Chancen einer regionalen Wertschöpfung durch Erneuerbare Energien in der Städteregion Aachen. Duisburg, Aachen: RISP and FiW; 2017. Jenniches S, Schneider J, Liesenfeld J. Policy-Paper Regionale Wertschöpfung durch Erneuerbare Energien in der Städteregion Aachen. Duisburg, Aachen: RISP and FiW; 2017.

Jenniches, S. Fuel for regional economies: what are the benefits of renewable energies? In: Science Trends, https://sciencetrends.com/fuel-for-regional-economies-what-are-thebenefits-of-renewable-energies/; 2018 [accessed 30 December 2019].

Blask K, Busse M, Etterer F, Heitepriem N, Herrmann P, Jenniches S. Regionale Landmanagerin werden. In: Schön S, Eismann C, Wendt-Schwarzburg H, Ansmann, T. Nachhaltige Landnutzung managen: Akteure beteiligen - Ideen entwickeln - Konflikte lösen. Bielefeld; Bertelsmann; 2019, p. 25-36.

Brühl S, Donner O, Türck-Hövener FJ, Schneider J, Ooms K, Hudjetz S, Lennartz F, Keysselitz B, Jenniches S, Liesenfeld J, Rischka M, Vankann M, Ptock A, Pilgrim T, Bornefeld B. Regionaler Energieplan Aachen 2030 - Gemeinsam zur EnergieRegion. Aachen, Stolberg, Duisburg, Aachen: BET, EWV, FiW, gaiac, IPW RWTH Aachen, RISP, Stadt Aachen, StädteRegion Aachen, Stawag; 2019.

\section{Engagement as Reviewer}

Energy Policy

Journal of Cleaner Production

Renewable and Sustainable Energy Reviews 
